\title{
Proposed Industrial Recovered Materials Utilization Targets for the Textile Mill Products Industry
}

May 1979

Prepared for:

U.S. Department of Energy

Assistant Secretary for Conservation

and Solar Applications

Office of Industrial Programs

Under Contract No. EC-77-C-03-1694

$\checkmark$ 


\section{DISCLAIMER}

This report was prepared as an account of work sponsored by an agency of the United States Government. Neither the United States Government nor any agency Thereof, nor any of their employees, makes any warranty, express or implied, or assumes any legal liability or responsibility for the accuracy, completeness, or usefulness of any information, apparatus, product, or process disclosed, or represents that its use would not infringe privately owned rights. Reference herein to any specific commercial product, process, or service by trade name, trademark, manufacturer, or otherwise does not necessarily constitute or imply its endorsement, recommendation, or favoring by the United States Government or any agency thereof. The views and opinions of authors expressed herein do not necessarily state or reflect those of the United States Government or any agency thereof. 


\section{DISCLAIMER}

Portions of this document may be illegible in electronic image products. Images are produced from the best available original document. 
This document was prepared by Booz-Allen \& Hamilton Inc., under direction by the office of Industrial Programs, Office of the Assistant Secretary for Conservation and Solar Applications, U.S. Department of Energy. The analysis and determinations indicated in this document have been used as a basis to propose recovered materials utilization targets for the textile mill products industry. This target is required to be established by Section 374A of the Energy Policy and Conservation Act as amended by the National Energy Conservation Policy Act. 

Neither the United Staies Govesnment nor any agancy thereed, nor any of thair employees, makes any

warranty. express or implied, or assumes eny legal liability or responsibility for the bccuracy.

represents that its usefulmess of any intormation, apparatus, product, of process disctosed, or

commercien ats

no: nesserily constitutes is imaly is endorsement. recommend tion or favoring by the Unitod

Stales Government or any apency thereof. The vieus and opinions or authus sjeresod herein do not

necessarily staie or reflect thosa of the United States Government or any ggancy thereof.

\section{Proposed Industrial Recovered Materials Utilization Targets for the Textile Mill Products Industry}

May 1979

Prepared by:

Booz-Allen \& Hamilton, Inc.

Bethesda, Md.

Prepared for:

U.S. Department of Energy

Assistant Secretary for Conservation

and Solar Applications

Office of Industrial Programs

Under Contract No. EC-77-C-03-1694 
TABLE OF CONTENTS

Page

Iunber

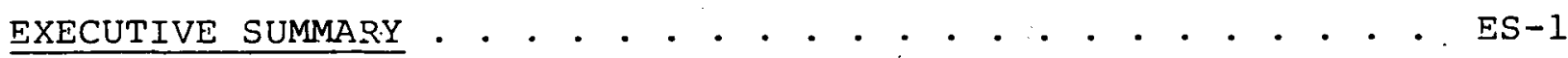

1. IIJTRODUCTION . . . . . . . . . . . . . . . . . . . . . . 1-1

1.1 MATERIALS RECOVERY TARGETS ARE REQUIRED BY

LAW FOR THE TEXTILE MILL PRODUCTS INDUSTRY . . . . 1-1

1.2 THE TEXTILE MILL PRODUCTS INDUSTRY CONSISTS

OF DIVERSE SUBSECTORS THAT PRODUCE A WIDE

VARIETY OF TEXTILE PRODUCTS . . . . . . . . . . . 1-3

1.3 RECOVERED MATERIALS TARGETS ARE COMPUTED

AS PERCENTAGES: RECOVERED MATERIALS ARE

TO BE SPECIFIED PERCENTAGE OF RAW MATERIALS

USED . . . . . . . . . . . . . . . . . . $1 . \cdots 7$

1.4 MATERIALS RECOVERY TARGETS WNERE ESTABLISHED

BY DETERMINING HOW MUCH RECOVERED MATERIAL IS

CURRENTLY USED IN EACH INDUSTRY SUBSECTOR AND

PROJECTING MAXIMUM POSSIBLE USE TO 1987 . . . . . . . 1 -9

2. OVERVIEW OF THE U.S. TEXTILE INDUSTRY . • . • . . . . . . $2^{-1}$

2.1 THE TEXTILE MILL PRODUCTS INDUSTRY CONSISTS

OF DIVERSE SUBSECTORS THAT PRODUCE A WIDE

VARIETY OF TEXTILE PRODUCTS . . . . . . . . . . . . 2-1

2.1.1 The TexLile Industry lan Be
Separated Into Two Tiers . . . . . . . . 2-3

2.1.1.1 First Tier of the Textile
Mill products Industry . . . . 2-3

2.1.1.2 Second Tier of the Textile
Mill Products Industry . . . . 2-b

2.1.2 Operations in the Textile Mill
Products Industry . . . . . . . . . . 2-5 
TABLE OF CONTENTS (Continued)

Page

Number

2.2 THE APPAREL INDUSTRY IS THE MAJOR USER

OF INTERMEDIATE TEXTILE MILL PRODUCTS . . . . . . . . 2-9

2.2.1 Structure of the Apparel Industry . . . . . 2-9

2.2.2 Product Quality is Carefully Controlled

in the Apparel Industry . . . . . . . . . 2-12

2.3 CONSUMERS REQUIRE HIGH QUALITY CONSISTENCY

IN THE TEXTILE PRODUCTS THEY BUY . . . . . . . . . . 2-13

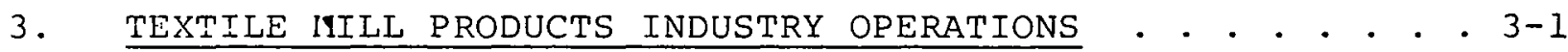

3.I TEXTILE PRODUCTION PROCESSES AFFECT THE

RESULTING PRODUCT'S CHARACTERISTICS . . . . . . . . . 3-1

3.1.1 The Primary Raw Material in the

Textile Industry is Fiber. . . . . . . 3-2

3.1.2 Yarn Formation Is a Series of

Mechanical Operations... . . . . . . 3-2

3.1.2.1 Opening, Blending, and

Picking Processes . . . . . . . 3-2

3.1.2.2 Carding Process........ 3-8

3.1.2.3 Drawing Proress . . . . . , . 3-8

3.1.2.4 Lapping and Combing Process . . . 3-8

3.1.2.5 Roving Process . . . . . . . 3-9

3.1.2.6 Spinning Proness . . . . . . 3-9

3.1.3 Production of Woolen Yarns . . . . . . . 3-9

3.1.3.1 Grading and Separation of

Wool............ . 3-10 
TABLE OF CONTENTS (Continued)

Page

Number

3.1.3.2 Cleansing and Treating of Wool........... . . 3-10

3.1.4 Yarn Formation From Man-Made Fibers . . . 3-10

3.1.4.1 Continuous Filament Fibers . . . 3-10

3.1.4.2 Treatments for Man-Made

Fibers ... . . . . . . . 3-10

3.1.5 Textile Fabric Formation . . . . . . . 3-11

3.1.5.1 The Weaving Process . . . . . 3-11

3.1.5.2 The Knitting Process . . . . . 3-1I

3.1.5.3 The Nonwoven Process . . . . 3-13

3.1.6 Textile Finishing Processes . . . . . . . 3-14

3.1.6.1 Singeing . . . . . . . . . . $3-14$

3.1.6.2 Bleaching... . . . . . . . 3-14

3.1.6.3 Mercerization . . . . . . . 3-14

3.1.6.4 Slack lercerization. . . . . . . 3-14

3.1.6.5 Shrinking . . . . . . . . . 3-15

3.1.6.6 Tentering . . . . . . . . . 3-15

3.1.6.7 Temporary stiffening . . . . . 3-15

3.1.6.8 Permanent stiffening . . . . . 3-15

3.1.6.9 Calendering. . . . . . . . . 3-15

3.1.6.10 Napoing . . . . . . . . . . 3-16 
TABLE OF CONTENTS (Continued)

Page

Number

3.1.6.11 Shape-Retentive Finishes . . . 3-16

3.1.6.12 Other Finishes . . . . . . . 3-16

3.2 NO TECHNOLOGIES ARE NOW NVAILABLE TO PRFPARF,

TEXTILE WASTE FOR USE IN MAKING FIRST TIER

YARN AND FABRIC ................ . 3-18

3.2.1 Fibrous waste Reprocessing... . . . . . 3-18

3.2.2 Yarn Waste Reprocessing . . . . . . . . 3-19

3.2.3 Fabric Waste Reprocessing . . . . . . . 3-20

3.3 NO TECHNICAL DEVELOPMENTS FOR IMPROVING THE

USE OF REPROCESSED TEXTILE WASTE ARE

ANTICIPATED BEFORE 1987 . . . . . . . . . . . . . 3-21

3.3.1 Automatic Waste Collection . . . . . . . 3-21

3.3.2 Open-End Spinning . . . . . . . . . . . 3-22

3.3.3 Nonwnven Fabric Production . . . . . . . 3-23

3.3 .4 Nverall Effects of Anticipated
Technological Changes . . . . . . . . . 3-24

Chapter 3 sources... . . . . . . . . . . . 3-26

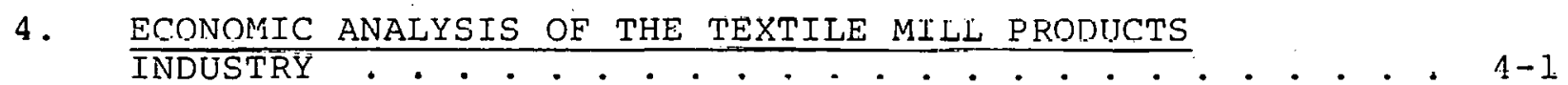

4.1 THE TEXTILE MILL PRODUCTS INDUSTRY IS
CHANGING BUT IT IS STILL HIGHLY COMPETITIVE $\quad . \quad . \quad . \quad . \quad 4-1$

4.2 THE DEMAND FOR TEXTILE MLLL PKUDUCTS HAS

GROWN SLOWLY AND CAN FLUCTUATE SIGNIFICANTLY

FOR A FIRM OR FOR THE INDUSTRY . . . . . . . . . . . 4-8

4.3 PRODUCTION COSTS FOR TEXTILE MILL PRODUCTS

ARE HIGH AND HAVE BEEN INCREASING . . . . . . . . . 4-13 


\section{TABLE OF CONTENTS (Continued)}

Page

Number

4.3.1 The Labor Cost Component . . ... . . . 4-13

4.3.2 The Material Cost Component ...... 4-15

4.3.3 The Energy Cost Component . . . . . . 4-20

4.3.3.1 Dry Processing........ 4- 4-20

4.3.3.2. Wet Processing........ 4-23

4.3.4 The Capital cost Component . . . . . . . 4-24

4.4 INCREASING COMPETITION FROM FOREIGN

IMPORTS HAS PROMPTED CHANGES IN THE INDUSTRY . . . . 4-26

4.5 THE TEXTILE MILL PRODUCTS INDUSTRY HAS BEEN

ECONORICALLY LESS SUCCESSFUL THAN OTHER

INDUSTRIES . . . . . . . . . . . . . . . . . . . . 4-30

4.6 SIGNIFICANT RETURNS ARE REQUIRED TO

ENCOURAGE NIEW INVESTMENTS, BECAUSE TEXTILE

MILLS OPERATE ON THIN MARGINS . . . . . . . . . . . 4-35

4.7 MATERIALS RECOVERY IS MARGINAL ECONOMICALLY

IN BOTH THE FIRST AND SECOND TIERS OF THE

TEXTILE MILL PRODUCTS INDUSTRY . . . . . . . . . . . 4-43

4.7.1 First Tier waste paterial Recovery . . . . 4-43

4.7.2 Second Tier Taste Material Recovery . . . 4-44 $\begin{array}{ll}\text { 4.7.2.1 } & \text { Waste Reprocessor } \\ & \text { Capital Expenditures... . . . . 4-45 }\end{array}$

$\begin{array}{ll}\text { 4.7.2.2 Waste Reprocessor } & \\ \text { Profit Margins . . . . . . . . . 4-47 }\end{array}$

4.7 .2 .3 Summary . . . . . . . . . . 4-48 
TABLE OF CONTENTS (Continued)

Page

Number

4.8 CAPITAL INVESTMENT IS NEEDED IN THE

TEXTILE MILL PRODUCTS INDUSTRY, BUT ACCESS

TO CAPITAL IS LIMITED . . . . . . . . . . . . . . . 4-48

4.8.1 Principal Use for Capital Funds. . . . . 4-49

4.8.1.1 Capacity Expansion . . . . . 4-49

4.8.1.2 Modernization of

Existing Facilities . : . . . . 4-49

4.8.1.3 Government Regulations

and Standards... . . ... . 4-51

4.8.2 Sources of Capital ... . . . . . . 44-53

Chapter 4 Sources . . . . . . . . . . . . . . 4-57

5. GOVERNMENTAL AND REGULATORY INFLUENCE ON THE U.S.

TEXTILE INDUSTRY $\cdot \cdot \cdot \cdot \cdot \cdot \cdot \cdot \cdot \cdot \cdot \cdot \cdot \cdot \cdot \cdot \cdot \cdot \cdot \cdot$. . . $5-1$

5.l SEVERAL ACENCIES OF THE FEDERAT, GOVERNMENT

IMPACT THE USE OF RECOVERED MATERIALS IN THE

TEXTILE MILL PRODUCTS INDUSTRY . . . . . . . . . 5-1

5.1.1 Environmental Frotectiun Agency . . . . . . 5-2

5.1.1.1 Rules and Regulations

on Hazardous Waste

Management . . . . . . . . . 5-2

5.1.1.2 Ruleg and Regulations on

Effluent Guidelines,

Pretreatment standards, and

Standards of Performance . . . 5-3

5.1.2 Federal Trade Commission . . . . . . . 5-5

5.1.2.1 Wool Products Labeling Act

of 1939, as Amended... . . . 5-5

$\begin{array}{ll}5.1 .2 .2 & \text { Textile Fiber Products } \\ & \text { Identification Act . . . . . } 5-8\end{array}$

5.1.3 Department of Labor . . . . . . . . 5-9

5.1 .3 .1 OSHA Cotton Dust Standards . . . 5-9 
TABLE OF CONTENTS (Continued)

Page

Number

5.1.3.2 OSHA Noise Standard...... . 5-12

5.1.4 Department of Commerce Is a Major

Participant in Determining International

Trade Policies in Textiles and Apparel : . 5-17

5.1.5 Treasury Department . . . ... . . . . 5-26

5.1.5.1 Rules and Regulations Under the Antidumping Act, 1921 . . . 5-26

5.1.5.2 Rules and Regulations Under the Tariff Act, 1932 . . . . . 5-26

5.1.6 Consumer Product Safety Commission

Administers The Flamnable Fabrics Act as Amended and Revised, 1967 . . . . . 5-27

5.1.7 Department of Defense Establishes

Specifications on Military Clothing. . . 5-28

5.1 .8 . Department of Energy . . . . . . . . 5-29

5.1.8.1 Power Plant and Industrial

Fuel Use Act of 1978 . . . . . 5-31

5.1.8.2 Natural Gas Policy Act . . . . 5-32

5.1.8.3 Energy Tax Act . . . . . . 5-32

5.1.8.4 National Energy Conservation

Policy Act . . . . . . . . 5-33

5.1.9 Summary of Governmental Impacts . . . . . 5-33

5.2 GOVERNMENT POLICY CHANGES COULD ENCOURAGE

MATERIALS RECOVERY .. . . . . . . . . . . . 5-35

5.2.1 EPA Rules and Regulations on Hazardous

Waste Management, Effluent Guidelines,

and Pretreatment Standards . . . . . 5-35 


\section{TABLE OF CONTENTS (Continued)}

Page

Number

5.2.2 FTC Rules and Regulations Under the

Tool Products Labeling Act... . . . . . 5-35

$5.2,3$ OSHA Cotton Dust Standard . . . . . . 5-35

5.2.4 OSHA Noise Standard . . . . . . . . . 5-36

5.2.5 Department of Commerce Policy Changes . . 5-36

5.2.6 Department of vefense Policy Changes . . . 5-36

6. CURRENT USE OF RECOVERED MATERIALS IN THE' 'I'E'X'L'LLE'

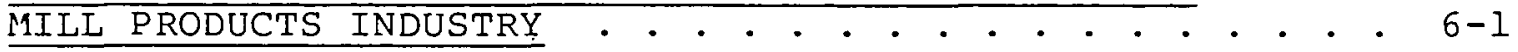

6.1 MOST U.S. TEXTILE MILL WASTE IS CURRENTLY

RECYCLED, BUT MAJOR SHIFTS IN VIASTE GENERATION

ANID USE ARE ANTICIPATED . . . . . . . . . . . . . . 6-I

6.2 CHANGING WORLD ECONOMIC CONDITIONS ARE CAUSING

A DECLINE IN THE USE OF RECOVERED TEXTILE

MATERIALS . . . . . . . . . . . . . . . . . 6-10

6.3 RECOVERED MATERIALS ARE SOMETIMES USED IN

TEXTILE INDUSTRIES OUTSIDE THE UNITEED STALES . . . . 6-12

6.4 THE USE OF RECYCLED MATERIALS FOR PRODUCIIIG

FINISHED GOODS OCCURS MOSTLY. IN THE SECOND

"TIER OF' 'I'HE TEXTILE MTLL PRODUCTS INDUETRY . . . . . 6-1.3

6.4.1 Falt Goods, Exrept. Woven Felts and Hats (SIC 2291) ............ $6=16$

6.4.2 Paddings and Üpholstery Filling $(\operatorname{sic} 2293) . . . \cdot . \cdot . \cdot . \cdot . \cdot .6-16$

6.4.3 Tire Cord and Fabric (SIC 2296) . ... . . 6-17

6.4.4 Nonwoven Fabrics (SIC 2297) . . . . . . 6-17

6.4.5 Cordage and Twine (SIC 2298). . . . . . 6-17

Chapter 6 sources. . . . . . . . . . . . . . . . 6-19 


\section{TABLE OF CONTENTS (Continued)}

Page

Number

7. LIMITATIONS ON THE USE OF RECOVERED MATERIALS IIN THE U.S. TEXTILE MILL PRODUCTS INDUSTRY . . . . . . . . 7-I

7.1 THE QUALITY OF TEXTILE PRODUCTS GOVERNS THEIR MARKETABILITY . . . . . . . . . . . . . . . . 7-4

7.1.1 Economic Importance of the Apparel Industry . . . . . . . . . . . . . . 7-6

7.1.2 Seasonal Impact on Apparel Industry . . . . 7-6

7.1.3 Trends in the Apparel Industry . . . . . . 7-8

7.1.4 Quality Control In the Apparel Industry ................. . 7-10

7.2 RAW MATERIALS MUST BE CONSISTENTLY HIGH IN QUALITY FOR THE TEXTILE MILL PRODUCTS INDUSTRY TO MEET PRODUCT SPECIFICATIONS . . . . . . . . . 7-17

7.2.1 Synthetic Fiber Manufacture . . . . . . . 7-17

7.2.2 Natural Fibers in Staple Fiber Processing ............... . 7-20

7.2.3 Avoiding Fiber Contamination . . . . . . 7-21

7.3 SEVERAL PROCESSES USED IN THE TEXTILE MILI PRODUCTS INDUSTRY IRREVERSIBLY CHANGE THE

CHARACTERISTICS OF FIBERS AND YARNS . . . . . . . . . 7-24.

7.3.1 Spinning and Weaving Operations . . . . . . 7-24

7.3.2 Preparation, Dyeing and Finishing Operations . . . . . . . . . . . . 7-26 7.3.2.1 Sizing-Desizing . . . . . . . . 7-26 7.3.2.2 Singeing . . . . . . . . . 7-27 
TABLE OF CONTEITS (Continued)

Page

Number

$\begin{array}{ll}7.3 .2 .3 & \text { Scouring . . . . . . . . . . . } 7-27 \\ 7.3 .2 .4 & \text { Dleaching . . . . . . . . . } 7-29 \\ 7.3 .2 .5 & \text { Merccrization . . . . . . . . . . . . . . . . . . } 7-29 \\ 7.3 .2 .6 & \text { Dyeing . . . . . . . . . . . . }\end{array}$

7.4 CHANGES IN THE CHEMICAL/PHYSICAL STRUCTURE

OF TEXTILE PRODUCTS DURING END-USE ARE

GENERALLY IRREVERSIBLE . . . . . . . . . . . . . . . 7-43

7.4.1 Mechanical Deterioration . . . . . . . . . 7-43

7.4.2 Photochemical Deterioration . . . . . . 7-44

7.4.3 Chemical Deterioration.......... . 7-44

7.4 .4 Biological Deterioration . . . . . . . . 7 444

Chapter 7 sources . . . . . . . . . . . . . . . 7-46

8. MATERIALS RECOVERY TARGETS FOR THE TEXTILE MILL

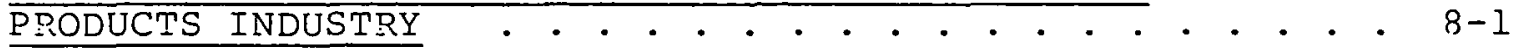

8.1 IIJ ORDER TO SET TARGETS, CURRENT RECYCLING

LEVELS WERE CALCULATED, AND PROJECTIONS TJERE

MADE TO 1987 . . . . . . . . . . . . . . . . . . 0.2

8.2 RECOVERED MATERIALS TARGETS MUST BE SET

GIVING CONSIDERATION TO MARKET-IMPOSED

QUALITY REQUIREMENTS . . . . . . . . . . . . . 8-7

8.2.1 The First Tier of the l'extile Mill

Products Industry (SICs 2211 through

2284 , except 2231 and 2283; SICs

2292 and 2295 )................. 8-10

8.2.2 Broadwoven Wool Fabric did Yarn Mills

(SICs 2231 and 2283)........... 8-12 
TABLE OF CONTENTS (Continued)

Page

Number

8.2.3 Felt Goods, Except Woven Felts and Hats (SIC 229I)............. 8-13

8.2.4 Padding and Upholstery Filling (SIC 2293). . . . . . . . . . . 8-14

8.2.5 Processed Waste and Recovered Fibers
and Flock (SIC 2294) . . . . . . . . 8-14

8.2.6 Nonwoven Fabrics (SIC 2297) . . . . . 8-15

8.2.7 Cordage and Twine (SIC 2298) . . . . . 8-16

8.2.8 Summary of Materials Recovery

Targets for the Textile Mill

Products Industry . . . . . . . . . 8-16

9. GOVERNMENT AND IINDUSTRY ACTIONS THAT COULD INCREASE

THE USE OF RECOVERED MATERIALS IN THE TEXTILE MILL

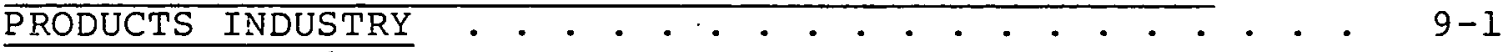

- 9.1 THE TEXTILE MILL PRODUCTS INDUSTRY CAN DO

LITTLE MORE TO INCREASE ITS USE OF RECOVERED

MATERIALS . . . . . . . . . . . . . . . . . . 9-2

9.2 SEVERAL POSSIBLE GOVERNMENT ACTIONS COULD

SITMULATE THE USE OF RECOVERED MATERIALS IN

THE TEXTILE MILL PRODUCTS INDUSTRY . . . . . . . . 9-3

9.2.I Government-Supported Research and

Development in Basic Textile Processes . . 9-4

9.2.2 Government-Supported Research and

Development in waste Reprocessing and

Handling Equipment . . . . . . . . . . 9-4

9.2.3 Amendments to the Wool Labeling Act

and Incentives for the Wool Reprocessing

Industry .... . . . . . . . . . 9-4 
TABLE OF CONTENTS (Concluded)

Page

Number

9.2.4 Mandatory Environmental and

Regulatory Standards (EPA and OSHA) . . . 9-5

9.2.5 Transportation Subsidies for Moving

Primary and Gecondary raste . . . . . . 9-5

9.2.6 Modification of Government

Purchasing Policies.. . . . . . . . 9-5

APPENDIX A

Title IV, Part 4, National Energy

Conservation and Policy Act, Section $374 \mathrm{~A}$ A-1

APPENDIX B

Representative Products Produced Within

Each Four Digit Sub-Division of the

Textile Mill Products Industry (SIC 22) . . B-1 


\section{LIST OF FIGURES}

Pase

Number

FIGURE F.S-1

Typical Waste Flov in the Textile Mill

Products Industry .. . . . . . . . . . ES-5

FIGURE ES-2

Sources of Waste for the Second Tier of the Textile Mill products Inciustry . . . . ES-6

FIGURE ES-3 Proposeci Recovered Materials margets

for the Textile Mill products Incustry . . . ES-8

FIGURE 2-1 Primary Structure of the U.S. Textile Industry . . . . . . . . . . . . . . . . 2-2

EIGURE 2-2 The TwO Tier Structure of the Textile

Mill Products Incustry........... . 2-4

FIGURE 2-3 Primary Process Flous in the Textile

Mill Droducts Industry . . . . . . . . . . . 2-7

FIGURE 2-4 Example of a Fabric Specification Data

Sheet . . . . . . . . . . . . . . 2-14

FIGURF: 3-1 Process for Cleaning and Dreparing Fibers . . 3-5

FIGURE 3-2 The Yarn Eorming Process . . . . . . . . . . 3-6

FIGURE 3-3 Major Operations in Man-Macie, cotton

and Woolen Yarn Forning Processes . . . . . 3-10

$\begin{array}{ll}\text { FIGURE } & \text { Total Energy Consumption and the Cost } \\ \text { of Purchased Fuels . . . . . . . . . . . . . . 4-22 }\end{array}$

$\begin{array}{lll}\text { FIGURE } & \text { Profit in the Textile Mill Products } \\ & \text { Inciustry . . . . . . . . . . . . . . . . . . 4-32 }\end{array}$

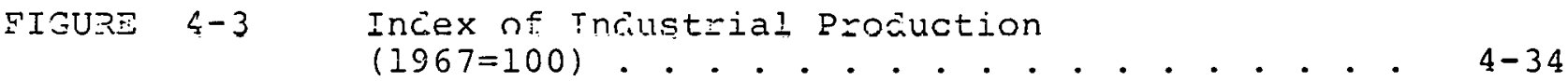

$\begin{array}{ll}\text { FIGURE 5-1 Textile Foreign Trace Balance, } \\ & 1972 \text { to } 1977 \text {. . . . . . . . . . . . . . 5-20 }\end{array}$ 


\section{LIST OF FIGURES (Concluded)}

Page

number

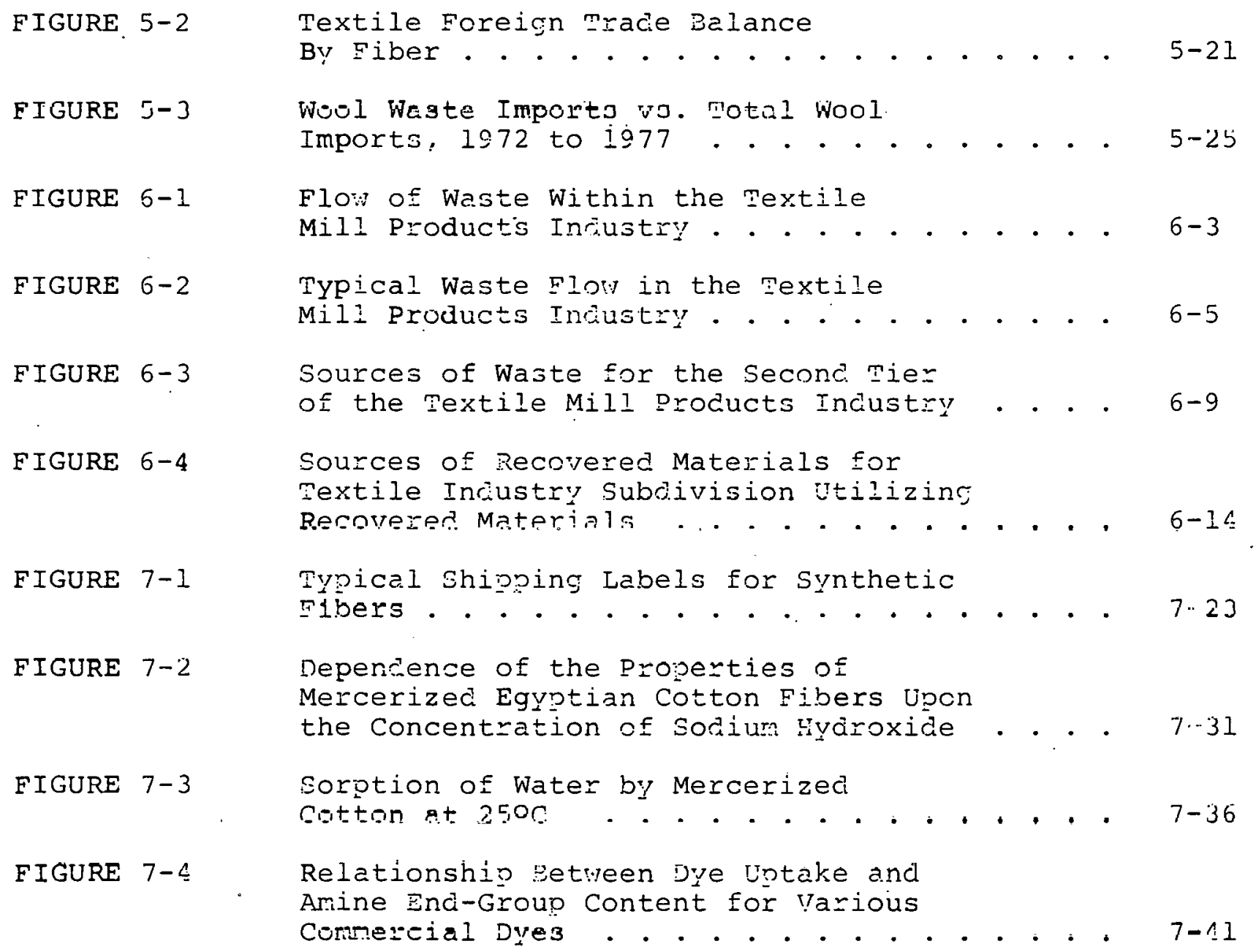




\section{LIST OF TAPLES}

Pace

Iumber

TABLE $1-1$

TABLE 2-?

TABLE 3-1

TABLE $3-2$

TABLE $3-3$

TABLE 3-4

TABLE $4 \because-1$

TABLE 4-2

TEABLE $4-3$

TABLE $4-4$

TABLE $4-5$

TABLF $4-6$

TABLE $4-7$

TABLE $\quad 4-3$
Subsectors of the Textile Mill

Products Industry standard Industrial

Cocie (SIC) Classification . . . . . . . . . 1-4

Apparel Inciustry Products... . . . . . . 2-10

Classification of Fibers . . . . . . . . 3-3

Fiber Characteristics... . . . . . . . : 3-4

Characteristics, Advantases; and Limitations of 3asic Weaves . . . . . . . 3-12

Selected Dye Classes: Their Uses: and

Characteristics . . . . . . . . . . . . . . 3-17

Market Shares in the Textile Mill

Droducts Industry (SIC 22). . . . . . . . . 4-3

Market Shares for the Apparel Incustry . . . 4-5

Mercer Guidelines for the Textile Mill

Procucts Incustry . . . . . . . . . . . 4-6

Total Fiber Consumption BY U.S.

Textile Milis (Milions of Pounas) . . . . 4-10

New Housing Units Started 1960 to 1977

(Thousancis) . . . . . . . . . . . . . 4-12

Wholesale Price Inciexes: Textile Mills:

Apparel, anci Incustrial products $(1967-1977)$. . . . . . . . . . . . 4-14

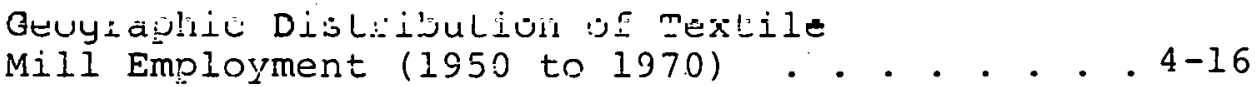

Drices for Natural anci Man-Macie

Eibers 1964 to 1976. (Dollars per Dounc) . . . 4-18 


\section{LIST OF TAPLES (Continued)}

Page

Number

$M A B L D-4 \cdots 9$

MLE $4-10$

TAEI

MAELE 4-12

T.A. $4-13$

$T \pi=L=4-14$

TASLS $4-15$

TALE $4-16$

TASLO $4-17$

$-\lambda \equiv I \Omega \quad 4-18$

TASTE $4-19$
R\&D Spencing in the Textile Mill

Procucts Industry vs $R \& D$ Spending in A11 Tnoustries (Inilions) . . . . . . . . . 4-2l

Capital Expenditures in the Textile Mi11 Products Industry . . . . . . . . . 4-25

Capltal Expencitures Pex Dlant Eor

Six Incustry serments

$4-27$

U.S. Textile Trade F.A.S. Values

(Milizions of Pounds) . . . . . . . . . 4-28

Ratio of U.6. Imports Eor Consurption

to npparent Do: nestic larket for Texti?e

Ili1] anc: Apparel Procucts .......... 4-29

Outout, Capacity, anc Operating zates

for the Textile Mill Procucts Industry . . . 4-33

Profit on Sales by Company and Year . . . . . 4-36

Profit on Stockholders' تquity by

Comoany anci Year . . . . . . . . . . . 4-37

Drice Inciexes of Principal Products and.

Major Cost Components in Yarn Mills

(SIC 2281.) $1975-1977$. . . . . . . . . . . . . 4-40

Price Incexes of Drincioai Droducts

anc Major cost Components in Cotton

Ercacioven Fabric (BIC 2211) 19751977 . . . 4-41

Price Truexee of princlpal products

and Hajor Cost Components in Man-Made

anc Silk Sroadvoven Eabrics (SIC 2221)

1975-1977. . . . . . . . . . . . . . . 4-42 


\section{LIST OF MAELES (Continued)}

\author{
TAELE $4-20$ \\ $\operatorname{TABTE}<-21$ \\ TADIE $\leq-22$ \\ TABLE $4-23$ \\ TAELE $\quad 4-24$ \\ TAETE 5-1 \\ TASIE $5-2$ \\ TASIS $5-3$ \\ TEALE 5-L
}

TASLS $5-5$

TASIE $5-6$

T.S.SE $5-7$
Textile Waste Price Changes

(January 1973 to January 1979) . . . . . . . 4 4-46

Capzcity Jtilization Rates

1967 to 1977 (Annual D.verage) . . . . . . 4-50

Capital spencing for Inodernization

and Expansion (Percent) . . . . . . . . 4-52

Dividend Payments for the Pextile

liill Drociucts Inciustry vs Those For

All Incustry (Percent of Earnings) . . . . . 4-54

Cost Increases for Textile irill

Ecuipnent (1960 to 1974).......... . 4-56

Bssential Provisions of the OSHA

Cotton Dust Stancara. . . . . . . . . . 5-11

Total Installed and Annualized

Compliance Costs of OSHA Cotton Dust

Stancara (Cost in Millions of Dollars) . . . 5-13

Typical Toise Levels in Textile Plants . . . $5 \cdots 15$

U.S. Foreign Tracie in Textile

Manufacture: Fiber Equivalent Exports,

Imports, anc rracle salance by wibers

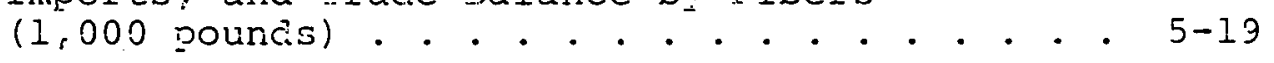

Ray Wool Content of Unitedi States

Exports of Domestic Wool Marufactures

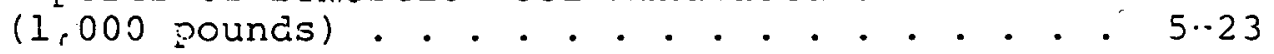

Raw Wool Content of inited States Inports

for Consumption of Wool Manufactures

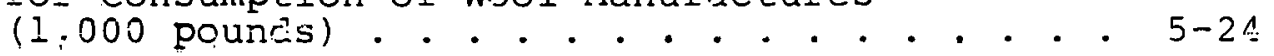

Typical Fabric Characteristics for which

Performance Specifications Are Estabiche? . 5-30 


\section{LIST OF TAELES (Concluded)}

Page

Number
TAELE $5-3$
Sumary of Government Influence on the Textile Inciustry . . . . . . . . . 5-34
MAELE 6-1
tepresentative Yearly Materials
Flin: in tho rextile dill products
Incistry
$6-4$
TAELE $6 \cdot \cdot 2$
Use of Waste in the Textile Mill
Products Industry . . . . . . . . . . . 5-3
TMEL: 7-1
Total rextile Incustry Fiber
Conoumption $u_{i}^{\prime}$ inc use . . . . . . . . . . 7-5
TAEIS $7-2$
Costs for a Fypical U.S. Apparel
Manufacturer . . . . . . . . . . . 7-7
TAELI 7-3 Marketing Seasons in the Apparel
Incustry . . . . . . . . . . . . . . . 7-9
"HLI 7-4 Current and projected Fiber content
in Âparel prociucts... . . . . . . . . . 7-1!
TABLE 7-5 Emamole of a Fabric specification
Dota Sheel . . . . . . . . . . . . . . 7-13
TABLE 7-6
Typical Specifications for Iiber Gracie
Terephthalic Acid for polyester Tiber
Manulactire. . . . . . . . . . . . . . 7-13
abL: 7-7
Types of iylon "Six-Six" Carpet Fiber
Produced by One Fiber Manutacturer . . . . . 7-22
TABLE 7-8
Change in $x$-Ray Unit cel structure on Mercerjzation of Collulose . . . . . . . 7-32
Tำ
Crystaline-Cellulose content of various
Materials Measured by the Rate of Acid
Hvirolysis in an Aqueous Solution of
Hyirochioric Acid and Ferric Chloride . . . 7-3A
mAI: 7-10 Strengthening single varn by
Mercerization............... . 7-35 


\section{LIST OF TAELES (Concludied)}

Pace

tumber

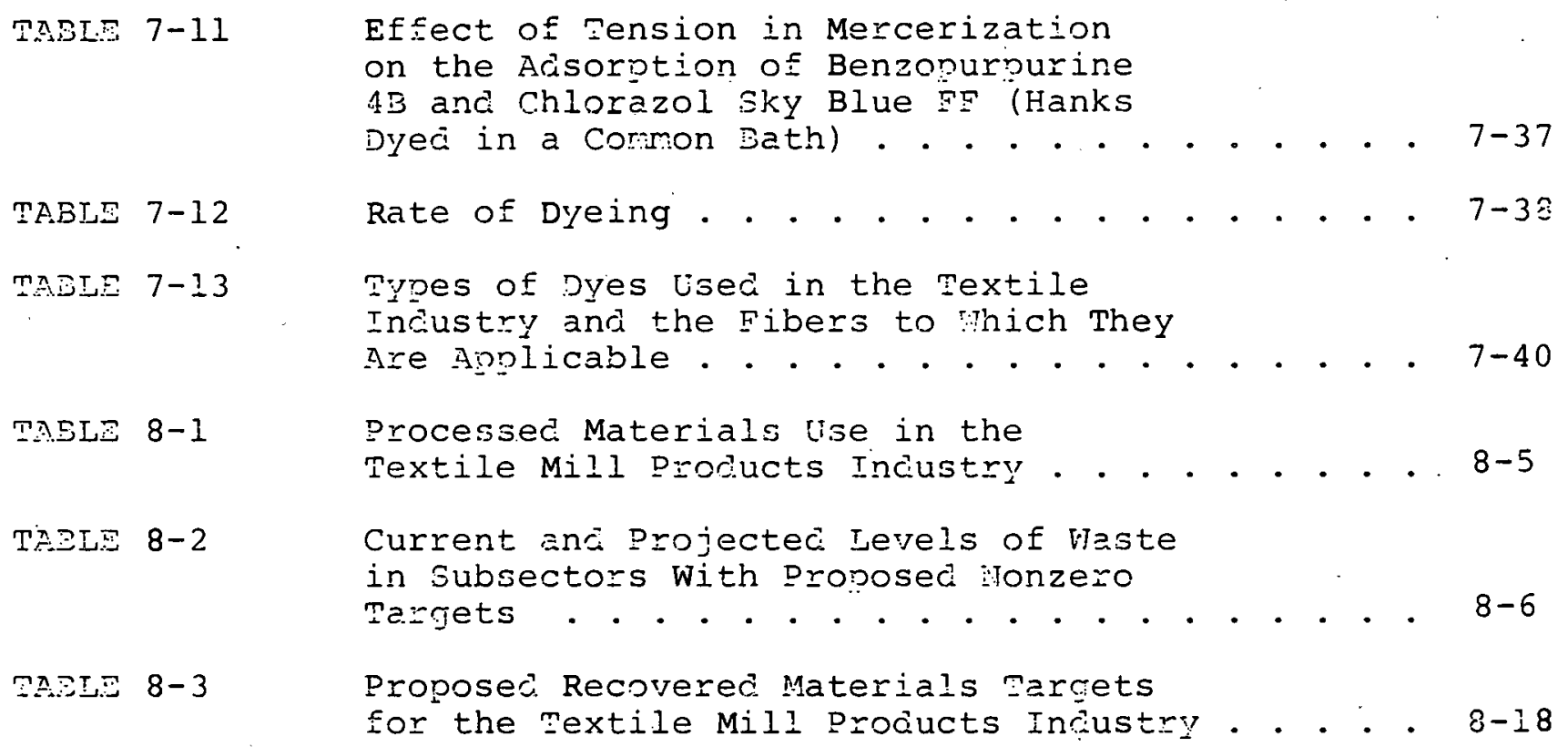




\section{EXECUTIVE SUMMARY}

The Congress, in the National Energy Conservation Policy Act of 1978 (NECPA), directed the Department of Energy to establish materials recovery targets for four basic industrial sectors. Included were the metals and metal products, paper and allied products, rubber, and textile mill products industries. The targets were developed to provide incentives for using energy saving recovered materials and to provide a yardstick for measuring progress and improvement in this endeavor. Wj.thin DOE, responsibility for establishing the targets was assigned to the Office of Industrial Programs, Assistant Secretary for Conservation and Solar Applications.

The NECPA indicates that the targets should represent the maximum technically and economically feasible increase in the use of energy-saving recovered materials that each industry can achieve progressively by January 1, 1987. Because of the limited duration of this study, these targets were not developed to represent the maximum level of energy conservation or the minimum level of energy use that can be attained in the textile mill products industry. The report on targets should also cover actions that are taken or that could be taken beiore January 1, 1987, by the industries or by the state, federal, or local governments. This includes all actions that could increase the use of recovered materials.

Materials affected by recovered materials targets include and are limited to aluminum, copper, lead, zinc, iron, steel paper and associated products, textile mill products and rubber. The use of these constituents for purposes other than the manufacture of the typical products was not considered in determining or satisfying the targets for each industry. This excluded the burning of waste material to produce heat or steam and the use of recovered chemicals and other by-products common to the four industries.

Using information gathered from the textile mill products industry and fror other textile-related sources, DOE has cieveloped proposed recovered inaterials targets for that industry. This report presents those targets and their basis and justification. 
1. THE TEXTILE MILL PRODUCTS INDUSTRY

The textile mill products industry is primarily a fabricated products industry. It processes natural fibers, man-made fibers, and continuous man-made filament into yarn and fabric. The Department of Commerce (DOC), in its Standard Industrial Code (SIC) classification, indicates that this diverse industry (SIC 22) is made up of 30 four-digit sublevels performing the following manufacturing operations:

Preparing fiber and subsequently manufacturing yarn, thread, braids, twine, and cordage

- Manufacturing broad woven fabric, narrow woven fabric, kn1t fabric, and carpcts and rugs from yarn

Dyeing and finishing fiber, yarn, knit apparel, and fabric

Coating, water proofing, or otherwise treating fabric

- Integrated manufacturing of knit apparel and other finished articles from yarn

- Manufacturing felt goods, lace goods, non-woven fabrics, and miscellaneoue textiles.

Typical operations of the textile industry include inspection and testing fibers, blending natural and manmale fibers, spinning into yarn, and weaving into fabric. This fabric is then inspected, dyed and finished to the specifications of the customer in one or more of many finishing processes. Some integrated mills produce finished products such as:

Sheoting

Toweling

Carpets and rugs

Knitted underwear and outerwear

'I'hread

Lace goods

Tire cord and fabric. 
Many of the approximately 7000 plants in the U.S. textile industry generate products that are used solely by other textile manufacturing operations:

- Apparel fabric is finished in the broad woven state and shipped to apparel manufacturers for cutting and sewing

- Finishing mills prepare greige goods for use in other operations

- Texturizing mills prepare continuous filament yarn for use in weaving and knitting operations.

Many times, because of the economics of scale, several greige mills will supply greige goods to one finishing plant for final processing.

Operational economics are extremely critical for the firms in the textile industry. The industry is mature and the largest firm commands about 7 percent of the market. There are over 5000 iirms in the United states with only about 80 of them publicly held. In fact, the second largest firm is a privately-held company. To be able to operate in such a competitive market, continuous production at minimum cost is imperative. However, it is essential to maintain the quality demanded by intermediate and final consumers such as the apparel industry, retail chains, and individual customers.

The textile mill products industry is also under pressure from foreign textile imports. The textile market is growing at about 3 percent per year and imports are groming at 6 percent. Cheaper foreign imports exert a Dressure on the industry to reauce its labor intensiveness by installing more modern enuinment. Progress has ane vill continue to be slow because of a lack of investment capital. The incustry's current profit is about 2 percent of sales and there is little capital available from the equity or debt markets.

There is also a large demand for capital created by several government regulations, prinarily the OSHA cotton dust and noise standards, and environmental standards. The industry has little availability of non-discretionary capital and this is not anticipated to change betreen nom anc $19: 7$. 
2. RECOVERED MATERIALS IN THE TEXTILE MILL PRODUCTS IIJDUSTRY

Waste material generated in the textile mill products industry is consumed in. secondary processes within the industry to improve production economics. Over 12 billion pounds of virgin fiber was purchased by the textile mill products industry in 1977. As shown in Figure ES-1, about 93.2 percent of this was consumed in producing first-tier products (those fashion and style conscious items that must adhere to strict quality specifications).

The remaining virgin fibers, which constitute abuut 6.8 percent of the total, are those that are too short to make an acceptable product (combcr and wool nuils) and those that are process operating waste (card strips, sweep waste, thread waste, mill or process ends). Those wastes become input material to the second tier segments of the industry which use them in felting, furniture padding, non-woven materials and the like (see Figure ES-2). In this tier, utility is the primary criteria as most of the products are not seen by the final customer.

This waste generated by the textile mill products industry plus the small amount purchased from waste dealers is almost totally utilized in the second tier products. The remaining, which is about 0.7 percent of the total purchased virgin fiber, is generally discarded to landfilis although some small portion is burned for boiler fuel. The total fiber dumped is about 100 million pounds per year and is considered to be unusable hy the waste reprocessors.

There is a waste prosersing cubocctor withii llie textile mill products industry. This was created by the need for the collection, classification, separation, and preprocessing of available waste from those firms with no second tier processes for delivery to the second tier firms. The waste processors tend to be small, privatelyowned companies that operate within a local area. These companies also operate on very low margins and cannot afford expensive preprocessing equipment or labor intensive manual sorting. As it is, many such firms are threatened by the capital requirements of the OSHA cotton dust and noise standards. It is not likely they could install new separating and preprocessing equipment even if it were available. 
FIGURE ES-1

Typical Waste Flow in the Textile Mill Products Industry

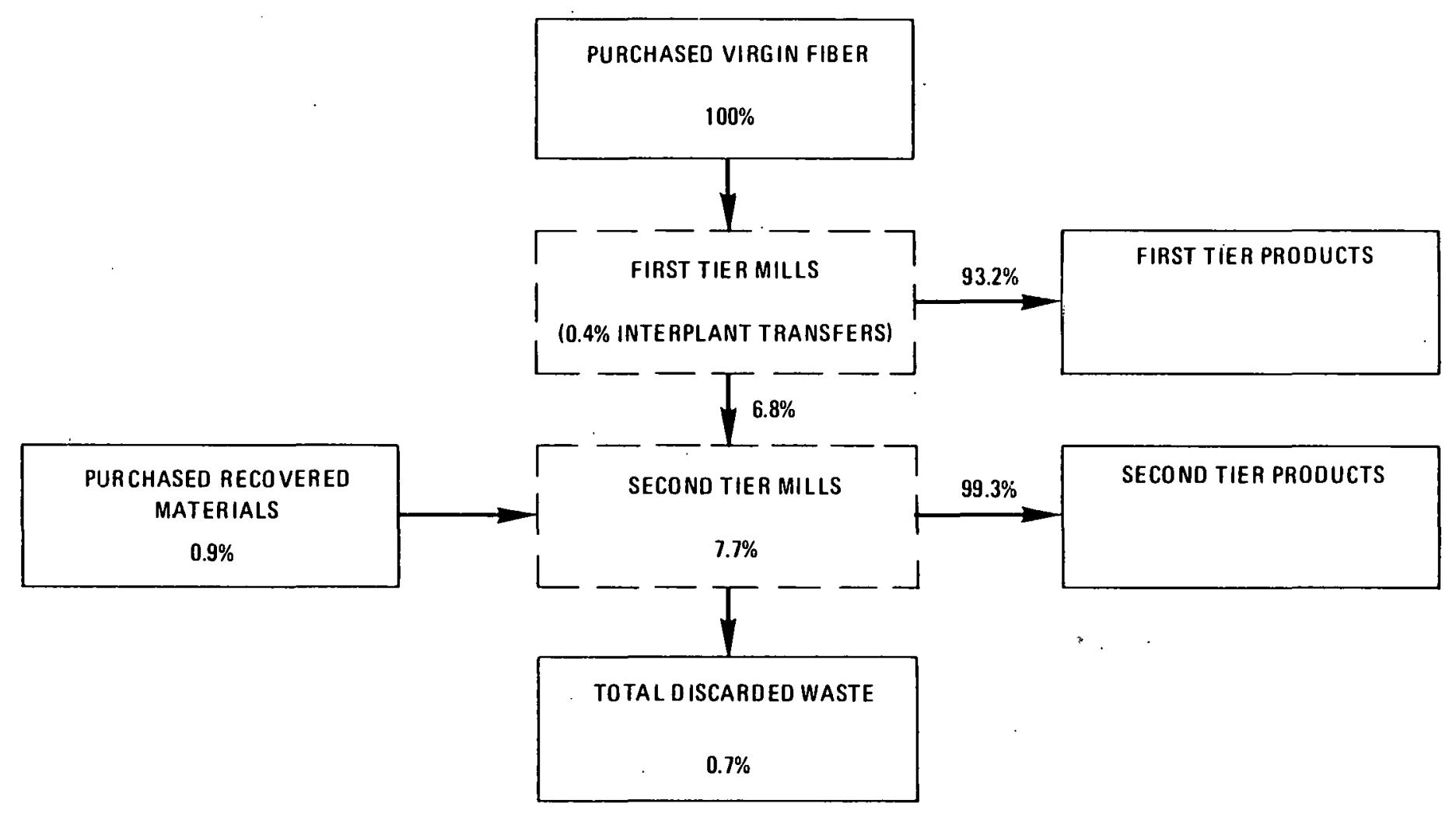




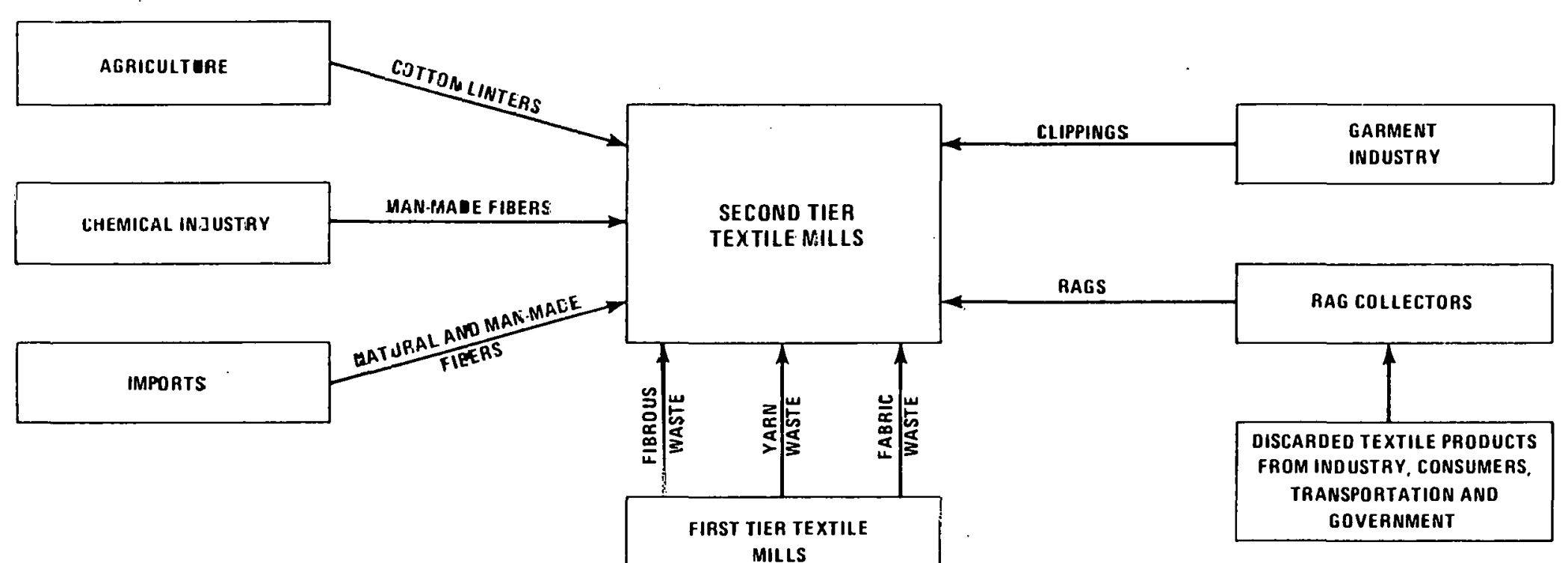

MILLS 


\section{PROPOSED RECOVERED MATERIALS TARGETS}

Materials recovery targets were developed for each four digit SIC sector for the textile mill products industry. This was accomplished by determining from available data the amount of material currently being reused and projecting that use to 1987. The targets established are the percentage of fiber used by each sector that is to be satisfied by recovered materials. Qualitative judgements were made about the effect of various factors, such as:

- Anticipated new technologies that could affect the use of recovered materials by 1987

- Anticipated changes in the intermediate and final markets that could affect the use of recovered materials

Taking into account the effects of such factors, the targets for 1907 were established.

Activities and policies that nay be undertaken by the industry and by state, Federal, and local governments to increase the use of recovered materials were also addressed.

Shown in Figure ES-3 are the proposed tarcets for the textile mill procucts incustry. As indicated, all but two of the fourndigit codes in the first tier of the textile mill procucts industry have a proposed target of zero percent. The only exceptions are wool processing, SICs 2231 and 2283. The folloring subsectors; then, all have targets of zero percent:

- SICs 2211 through 2284, except for SICs 2231 and 2283 (broad woven fabric and yarn mills, wool)

- SIC 2292 (Iace goods)

- SIC 2295 (coated fabrics, not rubberized). 
Figurle ES-3

Proposed Recovered Materials l'iryet for the realide Mill products Indinsty

\begin{tabular}{|c|c|c|c|c|c|}
\hline \multirow{2}{*}{ sac: } & \multirow{2}{*}{ indu: inY sel hoivision } & \multicolumn{2}{|c|}{ Pructisseo majebial } & \multirow{2}{*}{ 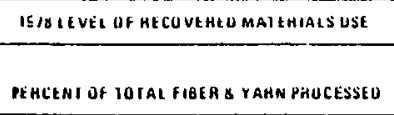 } & \multirow{2}{*}{ 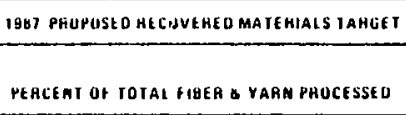 } \\
\hline & & $\begin{array}{l}\text { NILUON } \\
\text { PUUdos }\end{array}$ & $\begin{array}{l}\text { PEHCINI } \\
\text { Of IOTAL }\end{array}$ & & \\
\hline 2211 & BHUAD WUVEN FABA C MIL:S. CUTIOA & $.38 . .8$ & 16.6 & 0 & 0 \\
\hline 2221 & $\begin{array}{l}\text { BHOAU WONEN FAUH C MIL.S. } \\
\text { MEN MAUE FIHEH } 8 \text { S } 1 K\end{array}$ & 2.11 .5 & $1 . .6$ & $v$ & 0 \\
\hline 2231 & BRUAD WOVEN FABA C MIL LS, WOOL & 176.9 & 1.1 & 13 & 13 \\
\hline 2241 & NAHBUW FABRICS, GITTUN, WUOL, SILLSB MAA AACFF & $19: 3$ & 1.2 & 0 & $B$ \\
\hline 2251 & 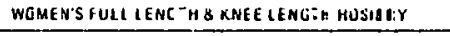 & 898 & 0.6 & 0 & $\theta$ \\
\hline 2252 & OTHEF HUSIE GY & 1204 & 0.8 & .0 & 0 \\
\hline 2253 & KMII GUIE AWE AR M HIS & 31587 & 20 & 0 & 0 \\
\hline 2254 & KNII UNDER AWE AH M UIS & 1475 & 09 & 0 & 0 \\
\hline 2253 & CIALUIAA KNII FAQQ C MIL .S & 1.0945 & 1.0 & 0 & 0 \\
\hline 2258 & WAHP ENIT FABHIC M.IS & 496.3 & 3.2 & 0 & 0 \\
\hline 2755 & KNITIING MILLS.NEC & 7 & 0.0 & 0 & 0 \\
\hline 2261 & BROAD WOUFN FABR C FINISIE HS, COCH JN & N/A & $\mathrm{N} / \mathrm{A}$ & 0 & $0^{\circ}$ \\
\hline 2262 & GHOAU WOVEN F ABROC FINISHEAS, SUIN $:$ MAN VAUI & N/A & M/A & 0 & 0 \\
\hline 2269 & TEXTUEFINIBHEAS, AEC & N:A & $N / A$ & 0 & 0 \\
\hline 2211 & WOVEN CAAPEIS B BLLS & 83. & 0.5 & $\mathbf{0}$ & 0 \\
\hline $22 m$. & TUREO CAHFEIS S RADS & $1,306.9$ & 8.4 & 0 & 0 \\
\hline 2219 & CARPE US \& RUGS, N.E.C. & 41.6 & $0:$ & 0 & 0 \\
\hline 2281 & $\begin{array}{l}\text { YAAN SPINUIMG MILI: } \\
\text { CUTIION, SII K, MAN M WUE FIEEAS }\end{array}$ & $2, \pi 06.1$ & 173 & 0 & 9 \\
\hline 2282 & 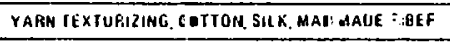 & 891.6 & 5.7. & 0 & 3 \\
\hline 2283 & YAAN MILIS, WUUT & 123.9 & 0.8 & 13 & 11 \\
\hline 2284 & IHAEAL MIUIS & 1992 & 09 & 0 & $\div$ \\
\hline 2291 & $\begin{array}{l}\text { FEII GUOUS, } \\
\text { EXCEPI WUVEX FELISE, HAIS }\end{array}$ & 58.5 & 0.4 & sy & 8 \\
\hline 2292 & LaCf COOOS & 50 & 0.0 & 0 & $c$ \\
\hline$\overline{2793}$ & PAUOING \& UPAUL LIE:AY FILLING & 330.0 & 2.1 & $\frac{93}{93}$ & $9 !$ \\
\hline 2245 & COATEU FABHICS NUT RUBBEGIZEO & 1962 & 09 & 0 & $a$ \\
\hline 2296 & THRE CURU 8 FABAIC & 741.4 & 4.8 & 0 & - \\
\hline 2247 & NON WOVEN FABAICS & $6+10$ & 4.1 & 17 & 15 \\
\hline 2298 & COALAAG \& TWINE & 95.2 & 0.6 & 22 & 22 \\
\hline 2794 & TEXTILE GUUUS, A E.C. & - & - & $=$ & \\
\hline
\end{tabular}


These sectors do not currently use recovered primary or secondary waste and are not likely to begin doing so by 1987. The technology will not be available for using recovered materials to make products that will be acceptable to the customers of these subsectors.

In the second tier of the industry, SIC 2296 is also proposed for a zero target. This subsector includes the tire cord and fabric industry, whose products are directly related to auto safety, making strength a primary characteristic. The requirements for production of tire cord and fabric are very strict and rigidly controlled by the Department of Transportation.

Several subsectors of the industry currently use primary waste and small amounts of secondary waste for their final products. Except for wool yarn spinning and weaving, these subsectors are in the second tier of the industry. The following materials recovery targets are proposed for them:

$\begin{array}{ll}\text { - SIC 2231 Broad Woven Fabric } & \\ \text { Mills, Wool: } & 13 \text { percent } \\ \text { SIC } 2283 \text { Yarn Mills, Wool: } & 13 \text { percent } \\ \text { - SIC } 2291 \text { Felt Goods, Except } & 80 \text { percent } \\ \text { Woven Felt and Hats: } & \\ \text { SIC } 2293 \text { Padding and Upholstery } & 93 \text { percent } \\ \text { Filling: } & 15 \text { percent } \\ \text { SIC } 2297 \text { Nonwoven Fabrics: } & 22 \text { percent } \\ \text { SIC } 2298 \text { Cordage and Twine: }\end{array}$

The waste reprocessing subsector does not to have the capability of substituting recovered materials since it does not use any virgin fibers; therefore, no target was established for SIC 2294.

Tt. should be noted that most of the companies involved in these subsectors are relatively small firms, consuming much less than 1 trillion Btu's per year. Therefore, they will not be required to report their recovered materials and energy use to DOE. 


\section{INTRODUCTION}

In the National Energy Conservation and Policy Act (NECPA) of 1978, the Congress directed the U.S. Department of Energy (DOE) to establish recovered materials targets in the following four industrial sectors:

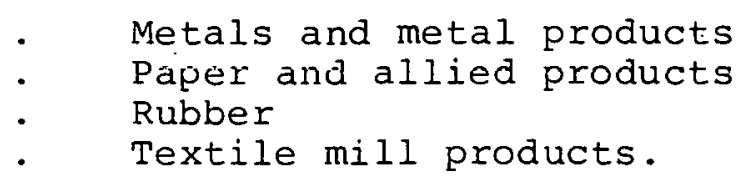

The stimulation for this project came at least partially from the success of various aluminum can recycling programs instituted by a major aluminum firm. The concept of using solid waste recovered materials is based on the premise that the reuse of these materials will conserve scarce raw materials and energy in both the process and feedstock forms. The use of such materials should also reduce environmental pollution by diminishing the amount of solid waste disposed of in landfills. This report describes targets for the textile mill products industry and shows how those targets were determined.

1.1 MATERIALS RECOVERY TARGETS ARE REQUIRED BY LAW FOR THE TEXTILE MILL PRODUCTS INDUSTRY

The National Energy Conservation and Policy Act of 1978* directs DOE to set voluntary targets for the increased use of energy-saving recovered materials. The targets to be established are for each of the following industries:

$$
\begin{aligned}
& \text { - Metal and metal products } \\
& \text { - } \quad \text { Textile mill products } \\
& \text { - Rubber. }
\end{aligned}
$$

Materials affected include aluminum, copper, lead, zinc, iron, steel, paper and allied paper products, textile mill products, and rubber. 
As stated in the law, the purpose of these targets is to conserve energy, conserve scarce natural resources, and protect the environment. This purpose is to be accomplished by :

- Establishing targets for the increased industrial utilization of recovered materials

- Creating procedures whereby the subject industries may cooperate with the federal government in the establishment and achievement of such targets

- Providing incentives (and as stated in the legisiative hlstory, a yardstick for measuring progress) for increased industrial utilization of energy-saving recovered materials in the subject industries.

Legislative histury preceeding passage of the NECPA indicated that Congress intended with this action to provide incentives for the four industries to increase their use of energy-saving recovered materials on a voluntary basis. As a result, the DOE was directed to consult with the major industries affected by the targets.

The HECPA states that the targets are to be established by DOE. (See Appendix A for relevant sections of the lav.) This responsibility ras assigned to the office of Incustrial Prograns in the office of Conservation and Solar foplications.

The NECPA indicatcs that the tarcets should represent the maximum technically and economically feasible increase in the use of energy-saving recovered materials that each industry can achieve progressively hy Tanuary 1, 1987. Because of the Iimited duration of this study, these targets were not developed to represent the maximum level of energy conservation or the minimum level of energy use that can be attained in the textile mill products industry. The targets should also cover actions that are taken or that could he taken before January 1, 1987, by the industries or by the state, federal, or local governments. This includes all actions that could increase the use of recovered materials.

Using information gathered from the textile mill products industry and from many other textile-related sources, DOE has developed materials recovery tarcets for the industry. This report presents those targets and their basis and justification. 

DIVERSE SUBSECTORS THAT PRODUCE A WIDE VARIETY OF TEXTILE PRODUCTS

The textile mill products industry is primarily a fabricated products industry. It processes natural fibers, man-made fibers, and continuous, man-made filament, fabricating them into finished yarn and fabric. The Department of Commerce, in its Standard Industrial Code (SIC) definitions, states that the textile mill products industry (SIC 22) includes establishments performing any of the following manufacturing operations:

- Preparing fiber and subsequently manufacturing yarn, thread, braids, twine, and cordage

- Manufacturing broad woven fabric, narrow woven fabric, knit fabric, and carpets and rugs from yarn

- Dyeing and finishing fiber, yarn, knit apparel, and fabric

- Coating, waterproofing, or otherwise treating fabric

- Integrated manufacturing of knit apparel and other finished articles from yarn

- Manufacturing felt goods, lace goods, non-woven fabrics, and miscellaneous textiles.

The 4-digit Standard Industrial Code numbers for SIC 22 are defined in Table 1-1. Appendix $B$ gives a representative listing of products in each 4-digit subsector of the textile mill products industry.

As indicated in Appendix B, textile mill products are quite diverse, ranging from knitted under- and outerwear to broad woven fabric used in the apparel industry. Several of the 4-digit operations are completely integrated, in that the basic fiber is processed into a finished item within one Iacilily. Reprecentative types nf integrated mills include the following:

$\begin{array}{ll}\text { - } & \text { Sheeting } \\ \text { - } & \text { Coweling } \\ \text { - } & \text { Knitted underwear and outerwear }\end{array}$


TABLE $1-1$

Subsectors of the Textile Mill Products Industry standard Industrial Code (SIC) Classification

\begin{tabular}{|c|c|c|}
\hline SIC & 2211 & BROAD WOVEN FABRIC MILLS, COTTON \\
\hline SIC & 2221 & $\begin{array}{l}\text { BROAD WOVEN FABRIC MILLS, MAN-MADE FIBER AND } \\
\text { SILK }\end{array}$ \\
\hline SIC & 2231 & $\begin{array}{l}\text { BROAD WOVEN FABRIC MILLS, WOOL (INCLUDING } \\
\text { DYEING AND FINISHING) }\end{array}$ \\
\hline SIC & 2241 & $\begin{array}{l}\text { NARROW FABRICS AND OTHER SMALLWARES MILLS, } \\
\text { COTTON, WOOL, SILK ANO MAN-MADE FIBER }\end{array}$ \\
\hline SIC & 2251 & $\begin{array}{l}\text { WOMEN'S FULL LENGTH AND KNFF I.ENGTH HOSIERY } \\
\text { MILLS }\end{array}$ \\
\hline SIC & 2252 & $\begin{array}{l}\text { HOSIERY MILLS, EXCEPT WOMEN'S FULL LENGTH } \\
\text { AND KNEE LENGTH HOSIERY }\end{array}$ \\
\hline SIC & 2253 & KNIT OUTERWEAR MILLS \\
\hline SIC & 2254 & KNIT UNDERWEAR MILLS \\
\hline SIC & 2257 & CIRCULAR KNIT FABRIC MILLS \\
\hline SIC & 2258 & WARP KNIT FARRIS MILLS \\
\hline SIC & 2259 & KNITTING MILLS, NOT ELSEWHERE CLASSIFIED \\
\hline SiC & 2261 & $\begin{array}{l}\text { DYEING AND FINISHING TEXTILES, EXCEPT WOOL } \\
\text { FABRIC AND KNIT GOODS }\end{array}$ \\
\hline SIC & 2262 & $\begin{array}{l}\text { FINISHERS OF BROAD WOVEN FABRICS OF MAN-MADE } \\
\text { FIBER AND SILK }\end{array}$ \\
\hline SIC & 2269 & $\begin{array}{l}\text { FINISHERS OF TEXTILES, NOT ELSEWHERE } \\
\text { CLASSIFIED }\end{array}$ \\
\hline SIC & 2271 & WÜVEN CARPET AND RUG MILLS \\
\hline SIC & 2272 & TUFTED CARPET. AND RUG MILLS \\
\hline SIC & 2279 & $\begin{array}{l}\text { CARPET AND RUG MII.ILS, NOT ELSEWHERE } \\
\text { CLA3SIFIED. }\end{array}$ \\
\hline SIC & 2281 & $\begin{array}{l}\text { YARN SPINNING MILLS, COTTON, MAN-MADE FIBERS } \\
\text { AND SILK }\end{array}$ \\
\hline SIC & 2282 & $\begin{array}{l}\text { YARN TEXTURIZING, THROWING, TWISTING AND } \\
\text { WINDING MILLS, COTTON, MAN-MADE FIBERS AND } \\
\text { SILK }\end{array}$ \\
\hline SIC & 2283 & $\begin{array}{l}\text { YARN MILLS, WOOL, INCLUDING CARPET AND RUG } \\
\text { YARN }\end{array}$ \\
\hline SIC & 2284 & THREAD MILLS \\
\hline $\mathrm{SIC}$ & 2291 & FELT GOODS, EXCEPT WOVEN FELTS AND HATS \\
\hline SIC & 2292 & LACE GOODS \\
\hline SIC & 2293 & PADDINGS AND UPHOLSTERY FILLINGS \\
\hline SIC & 2294 & $\begin{array}{l}\text { PROCESSED WASIE AND RECOVERED } \\
\text { FIBERS AND FLOCK }\end{array}$ \\
\hline $\mathrm{SIC}$ & 2295 & COATED FABRICS, NOT RUBBERIZED \\
\hline SIC & 2296 & TIRE CORD AND FABRIC \\
\hline SIC & 2297 & NONWOVEN FABRICS \\
\hline SiC & 2298 & CORDAGE AND TWINE \\
\hline SIC & 2299 & TEXTILE GOODS, NOT ELSEWHERE CLASSIFIED \\
\hline
\end{tabular}




$$
\begin{aligned}
& \text { Thread } \\
& \text { - } \quad \text { Lace goods } \\
& \text { Tire cord and fabric. }
\end{aligned}
$$

Many of the approximately 7,000 plants in the U.S. textile industry generate products that are used solely oy other textile manufacturing operations. Examples of these are as follows:

- Apparel fabric is processed only to the finished broad woven state in the textile mill products industry. It is then shipped to apparel manufacturers where it is cut and sewn into final consumer products. Therefore, the customer for this apparel fabric is the apparel manufacturer (SIC 23), not the final consumer.

- Textured yarn mills process continuous filament yarn extruded by the chemical industry to make it usable by the broad woven mills in weaving fabric.

- Many finishing mills only clean, desize, dye, print, and heat-set fabric produced in a weaving mill (greige goods) for use in an apparel factory or other end uses. The finishing mills are generally contract operations that have the fabric shipped into their facility, finished, and shipped back to the customer.

Process and economic balances within individual integrated companies dictate that one economic process, such as a finishing operation, be supplied greige goods (woven, but unfinished) by several knitting or weaving operations. As the industry is currently constituted, several dispersed spinning or weaving mills provide greige goods to a central mill that finishes its own greige goods in addition to those supplied by the other mills. This interdependency exists throughout the textile industry, with each succeeding operation imposing quality criteria and product characteristics on the output of each preceding process. For example, the weaving operations served by a relatively small yarn texturing mill require that the mill produce yarns with more than 300 different characteristics from one input material, such as polyester continuous filament yarn.

There are two general tiers of products in the textile mill products industry. The first tier (composed of many 
sublevels) contains 85 percent of all materials processed. It includes SICS 2211 through 2284 and SICs 2292 and 2295. In this first tier, a great deal of emphasis is placed on the style and fashion of the finished consumer product (apparel, sheets, towels, etc.). Changes in the quality, appearance, and feel of the products in this tier are dictated by consumer choice, not by the textile manufacturers. For example, one apparel firm cuts all of one apparel item from lengths of fabric no greater than 10 yards to help ensure color consistency in the various parts of the item that are to be fitted together.

Tn tho firct ticr, quality iunlıul uf the required fiber, yarn, and fabric characteristics is very strenuous. In many greige goods operations, each yard of fiber is inspected for defects and imperfections before being finished. A product that is not totally free of imperfections is downgraded to seconds or used in second lier products. In texturizing man-made continuous filament yarn, each package (doff or bobbin) of yarn is woven into a small sample, dyed with a sensitive color, and graded relative to a master. From 20 to 30 percent of all inspected packages are downgraded as a result of this inspection. The inspection guarantees the dyeability of the texturized yarn, a guarantee required by the weaving and finishing mills.

The second tier of prndurts in the textilc mill products industry include products where stress is on utility rather than style or fashion. Products in the second tier are covered by SICs 2291, 2293, 2294, 2296, 2297, and 2200 and vilsist uf cordage and rope, tire cords, furniture padding and stuffing, bandages, nonwoven products, apparel padding, felting, pocket linings, apparel linings, etc. Quality is maintained in this second tier of the industry, but emphasis is placed on strength, absorbency, and feel. Therefore, the textile manufacturcrc have more freedom in producing these items than they do with iteme in the first tier, and production economics are given more consideration. This sector of the industry represents less than 15 percent of the total fiber usage in the industry.

The textile mill produrts industry usee vory amnll naturally-occurring fibers (wool, silk, cotton), man-made fibers (polyester, nylon, acrylic, etc.) and man-made continuous filament yarn. Fabrication involves spinning a yarn from the small fibers or continuous filament and then weaving or knitting the yarn into a fabric. Innlike the textile industry in much of the rest of the world, the U.S. textile industry is subject to extremely exacting standards 
of color consistency, fabric feel, and appearance. These standards are imposed by intermediate consumers. Only very small quantities of undesirable fibers or foreign particles are allowed in the fabricating operation, so that drastic changes in raw material or operating procedures are unusual once a successful operation has been established. Therefore, recovered materials targets will have a great impact on the operation of the industry.

1.3 RECOVERED MATERIALS TARGETS ARE COMPUTED AS
PERCENTAGES; RECOVERED MATERIALS ARE. TO BE
SPECIFIED PERCENTAGES OF RAW MATERIALS USED

In response to NECPA provisions, DOE has determined that targets would be set for the use of recovered materials. Recovered materials were to be acquired from waste generated in the aluminum, copper, lead, zinc, iron, steel, paper and allied paper products, textile mill products, and rubber industries. The targets were also to apply only to the basic elements in the industry.'s products. In the textile mill products industry, this included natural staple fibers, man-made staple fibers, continuous man-made filament, and

The textile nill products inclustry very carefully reichs the fibers used in soinning: ancit it purchases continuous filar:ent and yarn by veight. Therefore, targets for the inciustry are clefined according to reight. Specifically: the recovered naterials tarset for fiber and yarn input consumed in a given textile rill prociucts operation. Thus; the tarcet excluces chemicals, dyestuffs: backings: cleaners, and all other ancillary itens usea in the manufacture of textile procucts.

Fibers and yarn used in the textile mill products industry are all produced by that industry. Copper has sometimes been used as a yarn in carpets to reduce hazards from static electricity, and some steel parachutes have been woven from thin steel yarn, but neither of these items is produced in significant quantities by the industry.

The appirel industry (SIC 23) is a large current and potential source of fabric waste. For purposes of establishiny the targets, it is considered as a source of waste material, even though it is not technically a part of the textile mill products industry, (as defined by the standard Industrial code). 
In determining the recovered materials target for the textile mill products industry, it was necessary to define the types of waste to be included. DOE considered the following three types of solid waste:

Reworkable Waste (Home Scrap). Reworkable waste, also known as home scrap, is a wasteproduct created during the normal manufacturing operation of the textile mill products industry and is returned directly to the process. Because of the quality requirements imposed by customers of the industry, reworkable wast.p i.s limited tu staple fibers that are still in the soft, untwisted form. These consist of the mill-ends of the soft, untwisted rope generated during the spinning process (silver, roving, pneumafil, drawing waste) and the noils combed from cotton (comber noils) which can be reintroduced into the total fiber consumed. It was decided that this waste would not be used in establishing or achieving the targets.

Primary Waste (Scrap). Primary waste is the waste generated in the manufacture of the basic textile mill products and used at another location. It includes the following waste products:

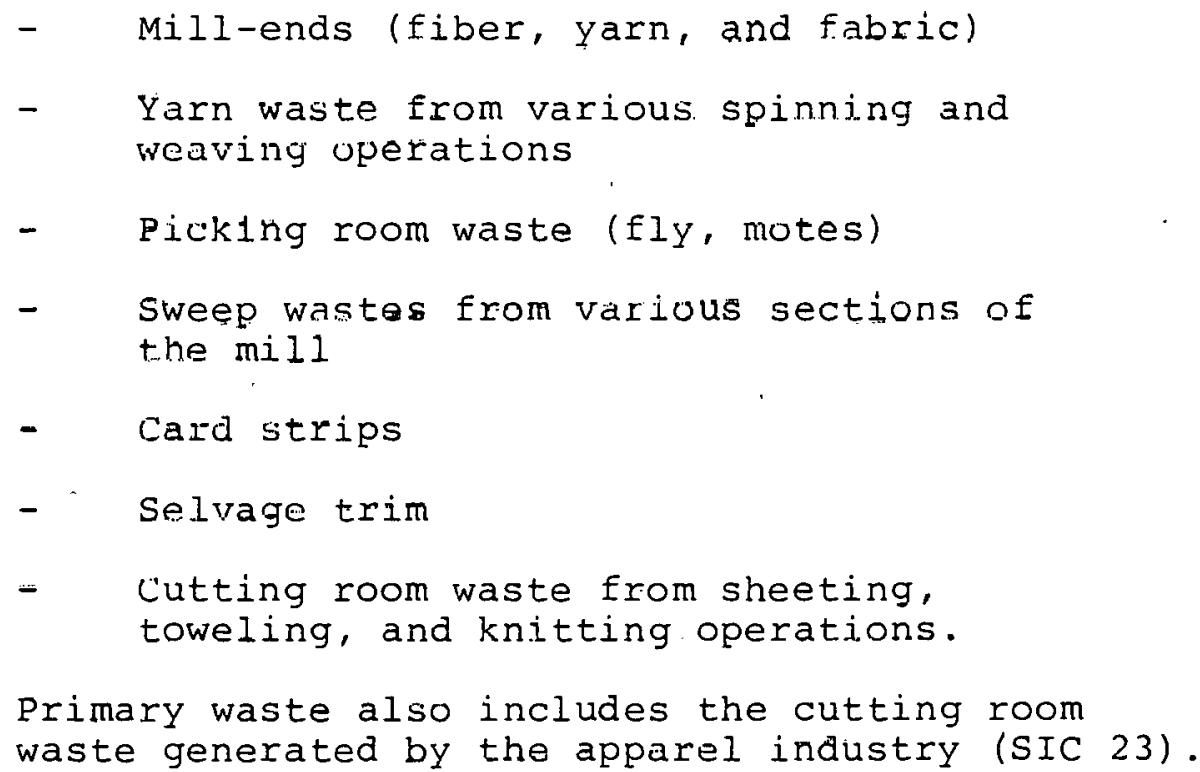


The SIC 22 waste product items can consist of from 1 to 20 percent of the fiber from which they are generated, depending on the raw material and the quality characteristics required in the final product. Currently, these waste products, almost entirely consumed by the second tier of the industry, are used to make the nonstyle- and nonfashion-oriented products. Primary waste will be included in establishing and achieving the materials recovery targets.

Secondary Waste (Scrap). Secondary waste, also termed post-consumer waste, consists of textilebased products (apparel, carpets, sheeting, toweling, etc.) that have been used and discarded by the final consumer. Most of this waste finds its way to the landfill, although it is sometimes collected and dispersed by charitable organizations. Secondary waste will be included in establishing and achieving the materials recovery targets.

In establishing targets for the textile mill products industry (SIC 22), it was decided to derive targets for each 4-digit SIC subsector, because the products, product characteristics, and quality requirements vary between subsectors. To take an extreme example, the furniture padding industry differs markedly from the broad woven cotton industry in operation and quality of final product. A target set for one would be entirely meaningless for the other.

Procedures discussed in the following section were used to establish realistic targets to be achieved by the textile mill products industry.

1.4 MATERIALS RECOVERY TARGETS WERE ESTABLISHED BY DETERMINING HOW MUCH RECOVERED MATERIAL IS CURRENTLY USED IN EACH INDUSTRY SUBSECTOR AND PROJECTING MAXIMUM POSSIBLE USE TO 1987

As required by the NECPA, the various subsectors of the textile mill products industry were consulted in setting the materials recovery targets. Industry associations consulted are as follows:

- American Apparel Manufacturers Association

- American Association for Textile Technology 
- American Cotton Linters Association

- American Textile Machinery Association

- American Textile Manufacturers Institute (ATMI)

- Boston Wool Trade Association

- Carpet and Rug Institute (CRI)

- Cordage Institute

- Felt Manufacturers Association

- International Non-wovens and Disposables Association (INDA)

Institute of Textile Technology

- Lace and Embroidery Association

- Man-made Fibers Association

- Nalional Association of Recycling Inductries

- Textile Dealers Association of America, Inc.

- Textile Fiber and By-Products Association

- Textile Quality Control Association

- Wool Bureau; Inc.

DQE and Booz, Allen representatives visited major operations within the industry as part of the targetsetting effort. Operations at most of the major companies in the industry were visited. In addition, several major waste dealers were visited to discuss their operations and the waste processing segment of the industry. All visits were made with several objects in mind:

- Gaining the required understanding of the major textile-making operations

- Determining how much recovered material is currently used in each subsector of the textile mil.j products industry

- Developing an understanding of the material flow in caoh subsestor of the indust.ry

Learning what characteristics the users of textile products require in those products

Inderatending the gengitivity of these characteristics to the use of recovered materials

- Determining any other factors that could influence the use of recovered materials in the industry.

During the DOE/BOoz, Allen visits, personnel at all the firms willingly provided information and answered questions. Cooperation was complete and the material provided was quite useful. 
A determination of material flow in the textile mill products industry was made. It was based on the information provided by private companies and by various trade associations, as well as being drawn from published data (primarily the Department of Commerce Census of Manufacturers). Using the data obtained, it was possible to ascertain how waste material is currently handled and how much is used in the manufacture of textile products. For those subsectors where the use of recovered materials was feasible, projections were made as to how much could be used in 1987. This was done in the following steps:

- Examining current and potential technologies for processing and using textile wastes

- Evaluating industry economic and financial conditions that will affect the use of recovered materials between now and 1987

- Estimating the effect of various regulations on the use of recovered materials

- Projecting the total use of fiber raw material in 1987 .

The projections thus obtained were established as targets for the various industry subsectors. Subsectors with zero targets were also evaluated, but no projections to 1987 were made. After the targets were established, actions for enhancing the use of recovered materials were evaluated. This included steps that could be taken by the textile mill products industry or by various levels of government. The activities considered included marketing and production changes by the industry. Government activities included items such as the following:

Changes in labeling regulations
- Changes in procurement procedures
- $\quad$ Lax incentives
- Changuarantees
. Government-sponsored research and development.

Each of these actions was evaluated to determine what effect it would have on the use of recovered materials.

This chapter has discussed the origin and purpose of recovered materials targets for the textile industry. The following chapters present information needed for the target-setting process and show how the targets were developed. 


\section{OVERVIEY OF PHE U.S. TEXTILE IMDUSTRY}

The textile industry is one of the major segments of the manufacturinc industry. Its two primary segrents, textile mill products ano apparel: produce a variety of intermediate and finished products (see Ficure 2-1). In ceneral, the textile mill products industry (SIC 22) processes natural fibers, man-racie fibers, and nan-made continuous filanent into fabric, yarn and some finishec procucts that recuire little aciitional processing. The apparel industry makes finished garments and accessories from the textile fabrics provided by SIC 22 .

This chapter presents an overvien of the textile incustry, provicing sone backgrounc on the folloring:

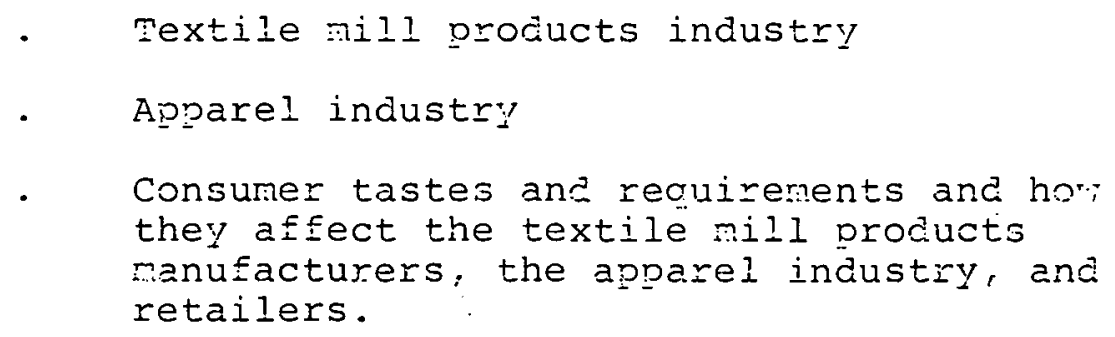
2.1 TIE TEXTLI ZILL PRODUCTS INDUSTRY CONSISTS OF DIVERSE SUPSECTOES THAT PRCDUCE A TDE YRPIETY OF TEYTIET PRCDUCTS

The U.S. textile nill products incustry consumed over 12.5 billion pounds of material in 1972. Eruncforming it. into a variety of soocis rozth nearly $\$ \$ 0$ billion. These goods, produceci in a variety of shapes, sizes, colors, anci textures; rere soli in various sectors for direct use or further processing.

The industry is primarily located in the southeastern and northeastern iecion's of the inited states. of the rore than 7:000 estajisisments (employing approximately 300,000 rorke:s) processing textile rill procucts in l372, over 90 percent are in these two regions: western zegions. Thoumh the northeastern ans southeastern regions have nearly the same nuriber of establishments, the shipments from the southeast are nearly three times those from the northeast because plants in the southeast are much larser. 
FIGURE 2-1

Primary Stzucture of the U.S. Textile Industry

RAW MATERIALS

- NATURAL FIBERS

- MAN-MADE FIBER aN J COMTINUUOUS FILAMENT
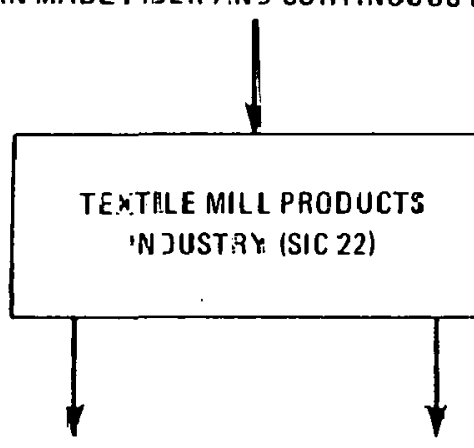

NASTE

- DUSi

- DIRT

- LEAVES

- CARPET ST RAPS
F NISHED PRDDUCTS

- SHEETING

- TONELj

- hOSIERY

- KNIT O JTER/UNDER WEAR

- carpets and RUGS

- FELTS

- lace gjods

- COATED fabRICS

- PADDINGS AND UPHOLSTERY FILLING

- NONWOJENS

- cordage and twine
OTHER MATERIALS

- leather

- plastics

- FURS

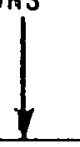

APFAAEL INDUSTRY (SIC 23)

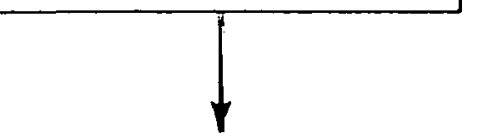

FINISHED PROUUCTS

- MEN'S AISD BOYS' APPAREL

- WOMEN'@ AND MISSES' OUTERWEAR

- WOMEN'S AND CHILDREN'S UNDERWEAR; HEADWEAR; CHILDREN'S OUTERWEAR

- miscellaneous apParel and ACCESSOAIES

- Miscellaneous fabricateo textile PRODUCTS 

2.1.1 The Textile Industry Can Be Separated Into Two

The industry can be separated into two tiers. The first tier produces a high quality, fashion-oriented, outerwear, while the second emphasizes the production of nonfashion, utility-oriented items. These second tier products are often made from reworked by-products or waste from the first tier. The 2-tier structure of the industry is shown in Figure 2-2. The following paragraphs contain several points about this structure.

\subsubsection{First Tier of the Textile Mill Products Industry}

The first tier of the textile mill products industry consists of firms that manufacture goods affected by consumer taste for high quality, fashion-oriented items. This tier processes raw cotton and other natural fibers and first quality, man-made fibers and continuous filament, producing items such as the following:

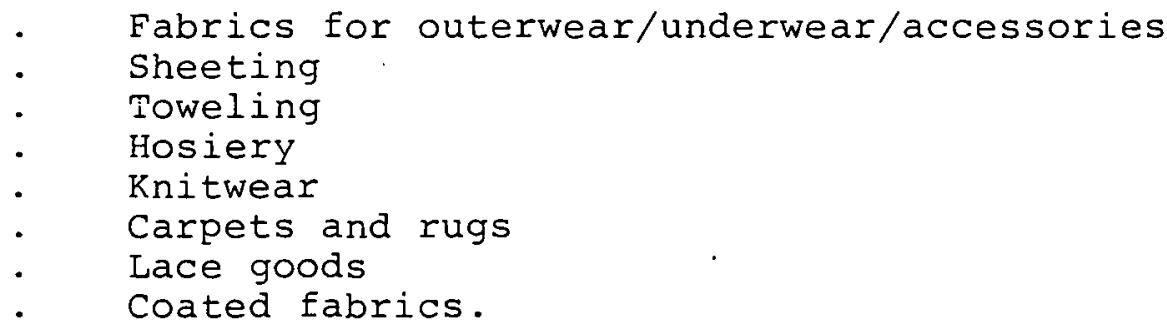

These items are all used in areas where visual qualities and texture are important. For example, the look and feel of fabric for shirts strongly influence consumer selection. For this reason, the requirements for consistency in color, texture, and fiber cuntenl are very high. Products cannot have random holes, lumps, inconsistent colors, or other variations and still earn consumer acceptance.

Quality control at this level of the industry is very strenuous. In many cases, each yard of fabric is inspected for defects dild imperfections beforc boing finisher. A product that is not totally free of imperfections is downgraded to seconds or used in second tiper products.

These strict requirements have caused many producers to linit the sources and types of raw material they will use. All first tier manufacturers use first quality, virgin 
FIGURE $2-2$

The Two Tier Structure of the Textile Mill Products Industry

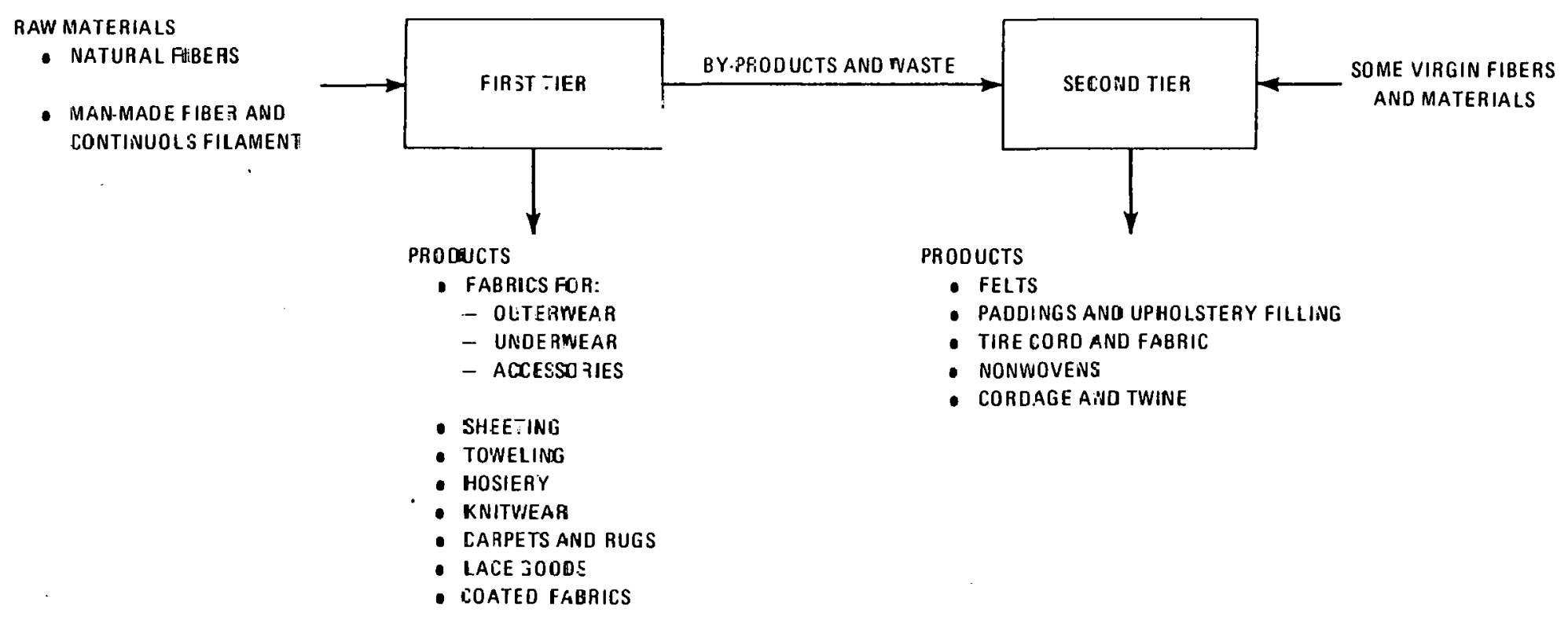


materials, assuring themselves of a more uniform product. Furthermore, first tier manufacturers usually select and retain specific suppliers of raw materials to further guarantee consistency for the consumer. The manufacturers must do this because of the variability of natural fibers, such as cotton, from field to field and the differences in chemical processes used to prepare man-made fibers and continuous filament.

\subsubsection{Second Tier of the Textile Mill Products Industry}

Second tier firms supply products that are subject to other, nonfashion requirements. These products are more utility-oriented, function being much more important than style or color. These products include the following:

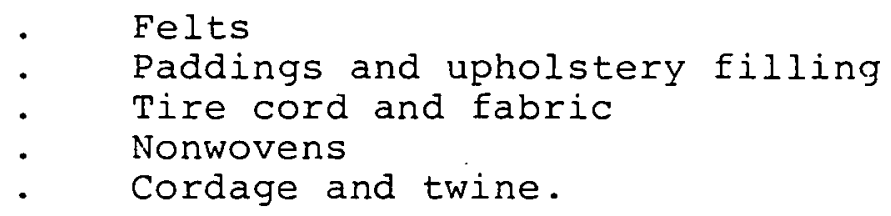

Specifications for these materials concern such matters as strength, durability, resiliency, fluffiness, density, and absorbency. Specifications for some of these products, mostly tire cord and some cordage, dictate the use of virgin fibers with high consistency so that a specific tensile strength or durability index can be achieved. In the manufacture of certain nonwovens, virgin materials may be needed because of the nature of the extruding process. However, a majority of the second tier items can be produced using by-products and waste from the first tier.

Most second tier products are hidden from view while in use (e.g., carpet pads, stuffing, and automotive insulation). The exacting color and texture requirements of the first tier are therefore not necessary. This makes the use of wastes and by-products acceptable, and it helps to reduce manufacturing costs.

\subsubsection{Operations in the Textile M111 Products Industry}

The Department of Commerce, in its Standard Industrial Code (SIC) definitions, indicates that the textile mill products industry (SIC 22) includes establishments engaged in performing any of the following operations: 
- Preparing fiber and subsequently manufacturing yarn, thread, braids, twine and cordage

- Manufacturing broad woven fabric, narrow woven fabric, knit fabric, and carpets and rugs from yarn

- Dyeing and finishing fiber, yarn, knit apparel, and fabric

- Coating, waterproofing, or otherwise treating fabric

- Integrated manufacturing of knit apparel and other finished articles from yarn

- Manufacturing felt goods, lace goods, nonwoven Eabrics, and miscellaneous textiles.

Operations in the textile mill products industry mechanically and chemically alter the characteristics of natural and man-made raw materials to form fabricated products. The raw materials are separated, stretched, twisted, and interlocked in various mechanical processes. The chemical processes used to process the fibers and cloth include cleaning, dyeing, coating, and chemically treating the materials to alter feel, color, and durability. Figure 2-3 shows the primary process flows in the textile mill products industry.

Textile mill products, as can be seen in Appendix B, are quite diverse, ranging from knitted under- and outerwear to broad woven fabric for the apparel industry. While several of the 4-digit operations are completely integrated in that the basic fiber is processed into a finished consumer item within one facility, most firms perform single operations, such as weaving, dyeing, or coating or are only integrated through a few operations. Representative types of integrated mills include the following:

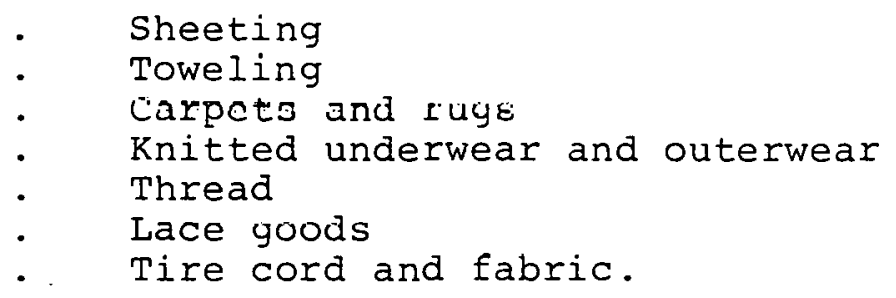


FIGURE 2-3

Primary Process Flows in the Textile Mill Products Industry
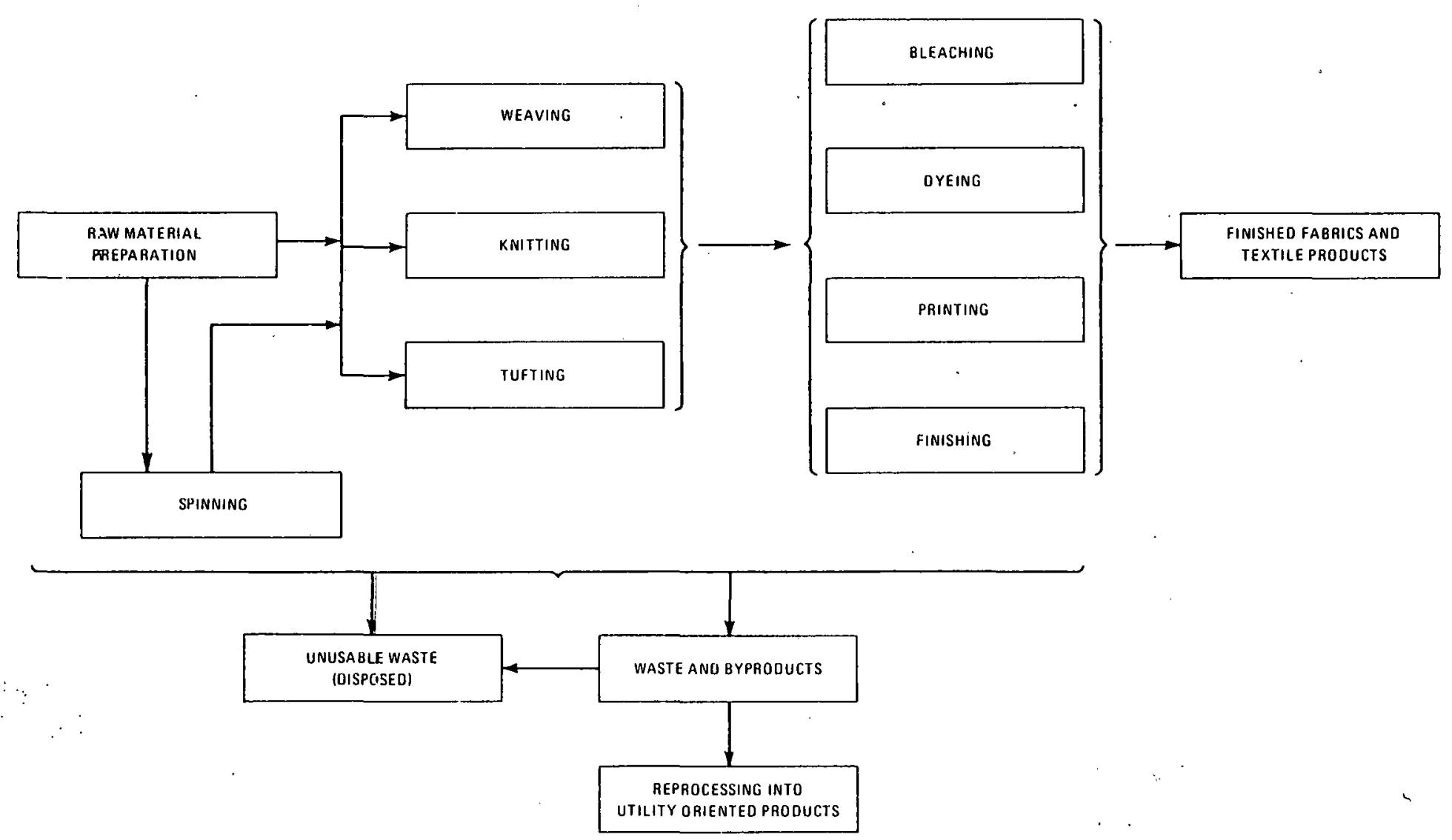
The four largest firms in the industry are integrated, and each has over $\$ 1$ billion in sales. Nevertheless, these four firms comprise only about 15 percent of the total sales in this highly fragmented industry. Integration has occurred to provide two principal benefits:

- The economics of the textile industry reward the integrated producers. With captive fiber and cloth production, mills can be balanced and unit costs reduced. The need for many separate marketing and distribution functions i.s alsn eliminated.

- Product quality and consistency can be ensured, because the processes at each step are the same from run to run. This allow the standardization of process steps, settings, and standards and improves the consistency of the product.

Industry trends are toward increased vertical integration, diversification, and consolidation, the reasons being the same as those just stated. However, the resulting reduction in process and market flexibility has caused many firms to become very reluctant to change any product characteristics, lest the changes have a negative effect on product economics, process variables, or marlsct acceptance.

Most mills are either partially integrated or specialized by process and depend on one another for economic success and process balance. As the industry is currently constituted, several dispersed spinning or weaving mills provide greige goods (woven but unfinished) to a central mill that finishes its own greige goods in addition to those supplied by the other mills. Such interdependency exists because of the minimum economic size required for the various processes and because of the relative economics of central batch processing of materials. In addition, most chemical processes require skills and knowledge different from those required for mechanical processing. Smaller mills often cannot afford the development of a chemical processing section, because of the high capital investment required. Interdependency also makes one group more aware of another group's quality criteria and product characteristics. This tends to further limit the flexibility of the smaller processors; for instance, they cannot introduce new blends or dyes that are not acceptable to another group's market. 
Because of the favorable economics resulting from integration and process balancing, the U.S. textile mill products industry has been able to reduce the penetration rate of low-cost foreign imports. However, even with additional process modifications to reduce labor costs, the textile trade deficit for 1977 was nearly $\$ 3.4$ billion. This competition from imports has forced the textile mill products industry to focus on two areas:

- Increased automation to offset rising labor costs

- Increased emphasis on product quality and consistency, to retain consumer demand for the higher priced U.S. goods.

The emphasis on quality and consistency extends to the apparel industry, the market most affected by imports.

2.2 THE APPAREL INDUSTRY IS THE MAJOR USER OF INTTERMEDIATE TEXTILE MILL PRODUCTS

The apparel industry (SIC 23) uses over 40 percent of all products fabricated in the textile mill products industry (SIC 22), producing a variety of garments and accessories. In 1978, the 16,000 plants in the industry produced goods valued at over $\$ 60$ billion retail. Table 2-1 gives examples of the items produced by this industry.

\subsubsection{Structure of the Apparel Industry}

Establishments in the apparel industry are generally much smaller than those in the textile mill products industry. In 1972, there were three times as many apparel industry plants, but they produced only about 15 percent more value added. The smaller apparel firms tend to be located near major wholesale and retail trade centers and normally produce higher style garments. Well over 50 percent of the plants are located in three states-New York, New Jersey, and Pennsylvania. The few large apparel plants are located generally in the Southeast. and tend to produce low style items such as work clothes.

The apparel industry has three major types of operation:

The manufacturer purchases fabric, employs production workers in his own plant to cut 
TABLE 2-1

Apparel Industry Products

FOR WOMEN AID GIRLS
DRESSES
SUITS
SLACKS
BLOUSE $/$ SHIRTS
OUTERWEAR/RAIRWEAR
FOUNDATION GARMENTS
INTIMATE APPAREL
UNIFORTS
HEADWEAR
PAJAMAS/ROBES
HOSIERY
SCARVES'KERCHIEFS
CAREER APFAREL

\begin{tabular}{ll} 
FOR MEN AND BOYS & FOR INFANTS \\
\hline T.AILORED CLCTHING & DAYWEAR \\
D.RESS PANTS & SLEEPWEAR \\
CASUAL PANTS & HOSIERY \\
WORK PANTS & HEADWEAR \\
JEANS & \\
OVERALLS/COVERALLS & \\
OUTERWEAR/RAINWEAR & \\
DFESS SHIRTS & \\
SPORT SHIRTS & \\
WORK SHIRTS & \\
UNDERWEAR & \\
UNIFORMS & \\
HEADWEAR & \\
PAJAMAS/ROBES & \\
HOSIERY & \\
TIES/SCARVES \\
CAREER APPAREL
\end{tabular}


and sew garments, and sells the finished products. He thus does all the work normally associated with manufacturing operations.

- The jobber has primarily entrepreneurial functions, such as buying new materials, designing and preparing samples, arranging with outside factories (contractors) for the manufacture of his garments from his own materials, and marketing the finished products. However, a number of jobbers also maintain cutting operations within their own establishments, relying on outside factories for other processing (sewing, finishing, etc.).

The contractor employs production workers in his own establishment to process materials owned by others, makes products to specifications, and is not involved in the sale of the finished garment.

Garments produced in the apparel industry are sold to customers through sales outlets and stores. The apparel industry is thus a link between the fabric producers and the garment sellers. Members of this latter group are perhaps most sensitive to consumer demands.

The apparel industry is much more fragmented than the textile mill products industry, although there are signs of gradual concentration and integration. Vertical integration is accomplished through the formation of textile/apparel or apparel/retail combination. Examples of textile/apparel combinations. include companies that have combined both knitting and cut-and-sew operations (e.g., Munsingwear and Hanes). Apparel/retail combinations include companies like Hart, Schaffner, and Marx or Walton clothing, Inc. Horizontal integration is achieved through product diversification. An example would be an apparel company that manufactures ladies' blouses and men's jackets or men's swimwear and ladies' robes. Both forms of integration can provide favorable economies of scale in production and distribution as well as ensuring more consistent markets and products. 
2.2.2 Product Quality is Carefully Controlled in the Apparel Industry

Product consistency is important for the typical apparel item. Many apparel manufacturers purchase by specification for just this reason. The properties of the material affect not only the quality of the final product but also its handling characteristics during production. Thus, to maintain continuity in production and product quality from lot to lot and style to style, little or no changes can take place in raw material properties. This means that a rigid set of practical epccifications must bc cotablished for those raw material properties which will cause major moditications in production mcthods or product quality. The specifications fall into two categories governing fabric performance and garment performance. Fabric performance during garment manufacturc includes properties lhat will affect any of the following:

- Handling on the cutting table and the cutting itself

- Sewing and handing during sewing

- Garment finishing.

Garment performance during use includes properties that affect any of the following:

- Normal wear

- Garment renovation (repair)

- Garment alteration.

If clear and carefully הnrumenter sperifisations aro communicated to the textile mills, the fabrics can be manufactured to meet the needs of the apparel producers. The specifications used for fabric quality typically include some or all of the following: .

Physical characteristics-weight, fiber content, count, type of finish, finished width

Performance characteristics-colorfastness, shrinkage, durable press features, strength, care characteristics, flame retardant features

- Visual defects-grading system and acceptable level 
- Shade tolerance variation-shade range between and within shipments, bales, or pieces

- Put up-package type and size, piece lengths or diameters, tube type, ticket information

- Test methods or procedures-used to ensure compliance with state requirements.

Apparel manufacturers trying to produce quality items at reasonable costs give their fabric requirements to the supplier and request assistance in selecting raw materials of acceptable quality. Figure 2-4 gives an example of a fabric specifications data sheet used to communicate specifications to the supplier. These written specifications do not constitute a complete list of all product characteristics; they only indicate primary specifications that are of special concern to the purchaser. The mills must still provide fabric that meets all recognized performance requirements, whether or not the requirements are enumerated in the written contract. This strong emphasis on fabric quality and consistency can be better appreciated if one understands the relationship between the textile mill products industry, the apparel industry, and retailers. This relationship is discussed in the following section.

2.3

CONSUPERS REQUIRE HIGH QUALITY CONSISTENCY I:T THE TEXTILE PRODUCTS THEY BUY

Many consumers use texture, color, consistency of fabric, and construction as their primary criteria in selecting textile products. This is true for the buying of outerwear, sheeting, carpet, and most products that are visible in normal use. Consumers of the second tier textile products (felts, paddings, tire cord, etc.) emphasize instead the utility of the products. This section discusses only the first group, the consumers of fashion and style oriented products.

Cunsulier Laste has a great influcncc on most of the apparel and fabric production in the United States. Consumer preferences creatc the demand for products. These preferences are of course influenced by advertising and merchandizing as well as by the ideas and preferences of apparel designers. (The designers, who exhibit their products at shows during the year, influence the ordering 


\section{SUGGESTED FABRIC SPECIFICATION DATA SHEET}

To be prepared by fabric supplier and given to buyer at the time of sample submission.

Fabric Manufacturer:

Fạtrir Brand Name:

Contract No.:

Date:

Fiber Content: Conotruction Name: Special Finish:

YARNS:

Generic Title: Size of Yarn(s): Warp/

Fill/

Wales: Course:

No. of turns per inch: Warp/Wales:

Texture Type: Warp/Wales:

Course/Fill: Course/Fill:

Construction Description:

Warp/Wales: Course/Fill: Finished Width

Weight: Per sq. yd. oz. \pm Per linear yd. oz. \pm

End use of the fabric:

\begin{tabular}{|c|c|c|c|}
\hline Property & Perfor & Level & Test Method \\
\hline $\begin{array}{l}\text { STRENGTH: } \\
\text { Tensile (W/F) } \\
\text { Tear (W/F) } \\
\text { Bursting }\end{array}$ & Average & Minimum & $\begin{array}{l}\text { ASTM-D } 1682-64 \\
\text { ASTM-D } 1424.63 \\
\text { ASTM-D } 231-62\end{array}$ \\
\hline STRETCH: $(W / F) \quad \%$ & & & ASTM-D 2594.72 \\
\hline $\begin{array}{l}\text { SHRINKAGE: } \\
\text { 1. Horhead Pressing (W/F) } \\
\text { 2. Home Laundry \& } \\
\text { Tumble Dry (W/F) }\end{array}$ & $\cdot$ & & $\begin{array}{l}\text { 1. As agreed between } \\
\text { buyer and scllor } \\
2 . \text { AATCC- } 124-75\end{array}$ \\
\hline $\begin{array}{l}\text { ABRASION: } \\
\text { Describe Method: } \\
\text { 1. } \\
\text { 2. } \\
\text { 3. }\end{array}$ & & & ASTM-D 1175.71 \\
\hline
\end{tabular}


FIGURE 2-4 (Continued)

\begin{tabular}{|c|c|c|}
\hline Property & Performance Level & Test Method \\
\hline $\begin{array}{l}\text { PILLING: } \\
\text { Describe Method: } \\
1 . \\
\text { 2. }\end{array}$ & & $\begin{array}{l}\text { ASTM-D } 1375.72 \\
\text { (For laboratory use } \\
\text { only. Not recommend- } \\
\text { ed for commercial ac. } \\
\text { ceptance.) }\end{array}$ \\
\hline $\begin{array}{l}\text { SNAGGING: } \\
\text { Describe Method: } \\
\text { 1. } \\
\text { 2. }\end{array}$ & & $\begin{array}{l}\text { AATCC. } 65.76 \\
\text { (For women's nylon } \\
\text { hosiery only) }\end{array}$ \\
\hline $\begin{array}{l}\text { STIFFNESS: } \\
\text { Before Washing } \\
\text { After Washing }\end{array}$ & & ASTM-D 1388.64 \\
\hline SMOOTHNESS & & AATCC $124-75$ \\
\hline SEAM SLIPPAGE & & ASTM-D 434-75. \\
\hline CREASE RETENTION & & AATCC $-88 \mathrm{C}-75$ \\
\hline $\begin{array}{l}\text { WATER REPELLENCY: } \\
\text { Impact } \\
\text { Spray }\end{array}$ & & $\begin{array}{l}\text { AATCC }-42.77 \\
\text { AATCC }-22.77\end{array}$ \\
\hline
\end{tabular}

\begin{tabular}{|l|l|l|}
\hline \multicolumn{1}{|c|}{ Colorfastness } & Minimum Rating & \multicolumn{1}{c|}{ Test Method } \\
\hline Laundering (C/S) & & AATCC-61-72-AATCC-124-75 \\
Crocking (W/D) & & AATCC-8-77 \\
Light & & AATCC-16A-77 \\
Perspiration - & AATCC-15-76 \\
Atmospheric gases & AATCC.23-75 \\
Clorine Retention & & AATCC-3-75 \\
\hline
\end{tabular}

\begin{tabular}{|l|l|l|l|}
\hline Visnal Defects & $\begin{array}{c}\text { Performance } \\
\text { Level }\end{array}$ & Int Maximum & Roll Reject \\
\hline $\begin{array}{l}\text { Points Per } 100 \\
\text { Square Yards }\end{array}$ & & & \\
& & & \\
\hline
\end{tabular}




\section{COMPLIANCE WITH SPECLAL REQUIREMENTS ON PRODUCT}

Mandatory Government Requirements:

(A.) F.T.C. Permanent Care Labeling:

(B.) F.T.C. Fiber Identification:

(C.) Country of Origin (where applicable)

(D.) Other:

\section{Package and Packing Requirements:}

Rolls ___ Flat Fold

Max. no. of pieces/put up

Yds/each, Min.

Max.

\section{Wrapper:}

Data on tag:

Mfg. Name

Style No.

Color

Gr. Wt.

Brand Name

Piece No.

Gr. Yde.

Net Yds.

New Wt. Length of shortest piece

Shipping Case: One shade per case

Label on outside of case to describe content:

Date of shipment Other

Special Instructions:

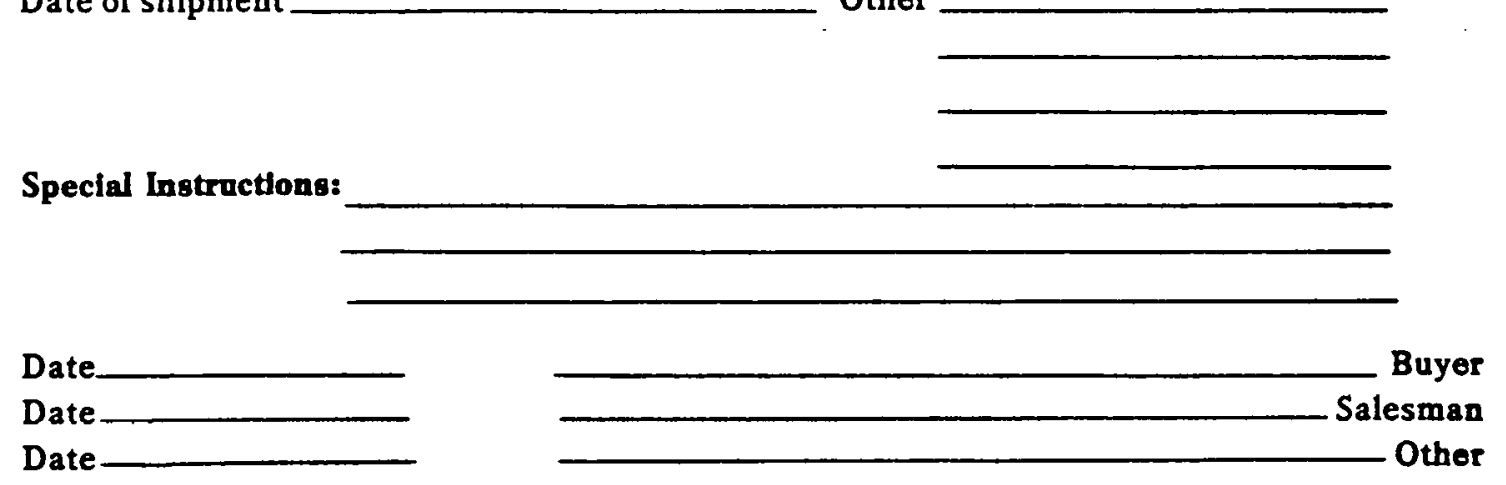


and subsequent production of goods.) Nevertheless, the key to success in the apparel trade is the ability to anticipate and satisfy the desires of consumers.

As previously mentioned, apparel producers are a link between the consumer and the textile mill products industry. In this position, they must try to balance some strong forces. The economics of the textile mill products industry dictate long runs and few changes in product mix, but the retail trade, influenced by consumer taste, must respond rapidly to changes in style. This causes apparel manufacturers to have a strong tendency toward offering the same types of fiber. and fabric construction from season to season and year to year while altering the garment style. Under normal conditions, an apparel manufacturer offers fewer than 10 percent changes in fiber or fabric construction arinually. Exceptions to this trend occur when innovations are made in fabric performance or styling. Recent examples of this include durable press, soil release, double knits, and denim.

It is clear, then, that garment producers are very interested in maintaining consistent product quality from run to run and year to year. Variations in fabric characteristics are not acceptable to most consumers of these products; consequently, such variations are also not acceptable to the producers. For this reason, the specifications for consistency of fabric and construction are very strict.

Partly because of this emphasis on quality and consistency in fabric and garment construction, the U.S. apparel industry has an international reputation for very fine products. This has allowed producers of U.S. textile goods to charge the higher prices demanded by their more expensive cost structures. As foreign industries become more automated and their product quality increases, U.S. retailers and the apparel industry may set more stringent specifications in order to retain their margin in quality over foreign competitors, a margin that would continue to generate consumer demand.

This chapter has presented an overview of the U.S. textile industry. The remainder of this report will focus on the sector to which the recovered materials targets apply, the textile mill products industry. The following chapter presents a discussion of the technology currently being used in the production of textile mill products. 


\section{TEXTILE MILL PRODUCTS INDUSTRY OPERATIONS}

The textile mill products industry (SIC 22) is made up of a large number of facilities designed for the conversion of natural and man-made fibers into fabrics and other textile-related products. This conversion occurs in a series of very complicated operations in which the fibers are processed, fabricated into yarn and fabric, and finished to a form acceptable to consumers. The industry must closely control the characteristics of its products in response to the strict specifications of its customers (e.g., the apparel industry and retail chains). These market-oriented specifications require the textile mill products industry to maintain tight controls in three basic areas:

- Raw material (fiber) inputs
Manufacturing operations
Chemical and mechanical treatments of fiber,
yarn, and fabric.

Processes in each of these areas are extremely complicated and the quality characteristics of the production output are highly sensitive to change. Therefore, the textile mill products industry devotes considerable time and resources to them. The current and projected technologies available to the industry for its production processes are discussed in the sections that follow.

3.1 TEXTILE PRODUCTIOI PROCESSES AFFECT THE RESULTING PRODUCT'S CHARACTERISTICS

The primary purpose of the textile mill products industry is to process fibers and continuous filament into labric for use in varinus textile products. Through careful control and combination of processes, desirable textile characteristics can be developed from various fiber types and fiber blends. This section examines the various fibers and common textile processing techniques indicating their influence on the quality and characteristics of the resulting fabric. The discussion will center on the system for processing cotton because the processing of man-made fibers is similar though somewhat less complicated due to the uniformity of the fibers. 
3.1.1 The Primary Raw Material in the Textile Industry is Fiber

The primary raw material in the textile industry is the fiber: Prior to the twentieth century, the only available fibers were those derived from either animals or plants. These fibers, primarily cotton and wool, were the dominant fibers in the textile industry until the advent of man-made fibers. Now there are hundreds of fiber types available; each tyne having its own special characteristics. When different fiber types are combiner or blended, the pruperties of the individual fibcrs are alsu combined.

Fibers available to the textile industry are divided into two categories-natural fibers and man-made fibers. Man-made fibers are obtained from cellulosic or synthetic materials, whereas natural fibers are derived from animals or plants. Table 3-1 lists major fibers and gives their source or composition.

Fibers are transformed into final yarn and fabric products through various manufacturing processes. Customer orders specify the fiber or combination of fibers that is desired. Table 3-2 lists some of the most important characteristics possessed by the various fibers.

\subsubsection{Yarn Formation Is a Series of Mechanical operatinns}

Yarns are furmed through several mechanical operations. In these operations, the fibers are cleaned and preparcd for spiming into the desired yarn. In order to determine the exact operations and amount of processing necessary for the production of a particular yasll, the eype and quality of the fiber and the end-use of the yarn must be known. Figures $3-1$ and $3-2$ give operatinns generally used in the production of cotton yarn. These operations are described in the following paragraphs.

\subsubsection{Opening, Blending, and Picking Processes}

The opening, blending, and picking processes are interconnected preparatory operations. Opening eliminates dirt, leaves, seeds, and other forcign matter from the mixed 
TABLE 3-I

Classification of Fibers

\begin{tabular}{|c|c|c|}
\hline . TYPE & NAME OF FIBER & SOURCE OR COMPOSITION \\
\hline \multicolumn{3}{|c|}{ NATURAL FIBERS: } \\
\hline VEGETABLE & $\begin{array}{l}\text { COTTON } \\
\text { LINEN } \\
\text { JUTE } \\
\text { HEMP } \\
\text { SISAL } \\
\text { KAPOK } \\
\text { RAMIE } \\
\text { COIR } \\
\text { PINA }\end{array}$ & $\begin{array}{l}\text { COTTON BOLL (CELLULOSE) } \\
\text { FLAX STALK (CELLULOSE) } \\
\text { JUTE STALK (CELLUL OSE) } \\
\text { HEMP OR ABACA STALK (CELLULOSE) } \\
\text { AGAVE LEAF (CELLULOSE) } \\
\text { KAPOK TREE (CELLULOSE) } \\
\text { RHEA OR CHINA GRASS (CELLULOSE) } \\
\text { COCONUT HUSK (CELLULOSE) } \\
\text { PINEAPPLE LEAF (CELLULOSE) }\end{array}$ \\
\hline ANIMAL & $\begin{array}{l}\text { WOOL } \\
\text { SILK } \\
\text { HAIR }\end{array}$ & $\begin{array}{l}\text { SHEEP (PROTEIN) } \\
\text { SHLKWORM (PROTEIN) } \\
\text { HAIR-BEARING ANIMALS (PROTEIN) }\end{array}$ \\
\hline MANMADE FIBE & $\begin{array}{l}\text { RAYON } \\
\text { ACETATE } \\
\text { TRIACETATE }\end{array}$ & $\begin{array}{l}\text { COTTON LINTERS OR WOOD } \\
\text { COTTON LINTERS OR WOOD } \\
\text { COTTON LINTERS OR WOOD }\end{array}$ \\
\hline $\begin{array}{l}\text { SYNTHETIC } \\
\text { LONG-CHAIN } \\
\text { POLYMERS }\end{array}$ & $\begin{array}{l}\text { NYLON } \\
\text { POLYESTER } \\
\text { ACRYLIC } \\
\text { MOOACRYLIC } \\
\text { SPANOEX } \\
\text { OLEFIN } \\
\text { SARAN } \\
\text { VINYON }\end{array}$ & $\begin{array}{l}\text { POLYAMIDE } \\
\text { DIHYORIC ALCOHOL ANO TEREPHTHALIC ACID } \\
\text { ACRYLONITRILE (AT LEAST 85\%) } \\
\text { ACRYLONITRILE (35\%-84\%) } \\
\text { POLYURETHANE (AT LEAST 85\%) } \\
\text { ETYYLENE OR PROPYLENE (AT LEAST 85\%) } \\
\text { VINYLIDENE CHLORIDE (AT LEAST 80\%) } \\
\text { VINYL CHLORIDE (AT I.FAST } 85 \% \text { ) }\end{array}$ \\
\hline MINERAL & $\begin{array}{l}\text { GLASS } \\
\text { CERAMIC }\end{array}$ & $\begin{array}{l}\text { SILICA SAND, LIMESTONE, AND OTHER MINERALS } \\
\text { MINEAALS }\end{array}$ \\
\hline METALLIC & METAL & ALUMINUM, SIL VER, GOLO, STAINLESS STEEL \\
\hline RUBBER & RUBBER & NATURAL OR SYNTHETIC RUBBER \\
\hline
\end{tabular}




\begin{tabular}{|c|c|c|c|c|c|c|c|c|c|c|c|c|c|c|c|c|c|c|}
\hline & & 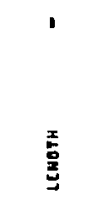 & $\frac{w}{5}$ & 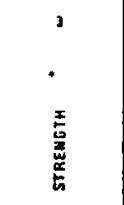 & 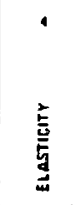 & 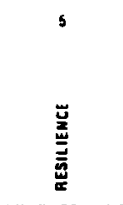 & 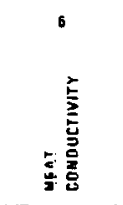 & 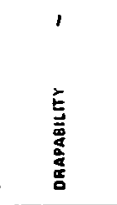 & 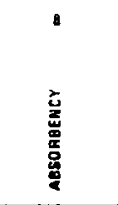 & 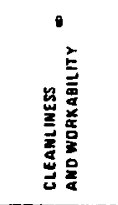 & 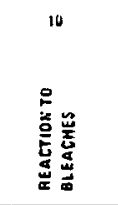 & 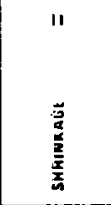 & 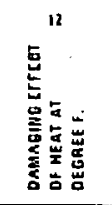 & 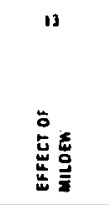 & 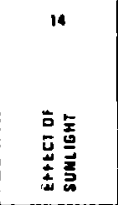 & 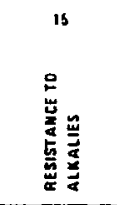 & 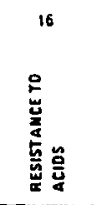 & 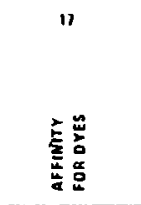 \\
\hline \multirow{4}{*}{ 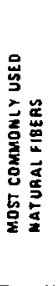 } & corrun & $\begin{array}{l}\text { x ro: } 26 \\
\text { incters }\end{array}$ & tartit & c0000 & 10w & veariun & VEAT GOON & veAYiow & 5004 & 0000 & vearguod & HIOH & Low $300 \mathrm{r}$ & low & MIGH & EXCELLEMT & MONE & SAIA TO GO0OO \\
\hline & moot & "UNCHES & Mamisal & & $\begin{array}{l}\text { VERY } \\
\text { HIGH }\end{array}$ & veAY LOOO & $\begin{array}{l}\text { NUN. } \\
\text { COMCUCILA }\end{array}$ & EXCELIEN & ExcELIEAT & ruOR & $\begin{array}{l}\text { MoufaAIE } \\
\text { To rouf: }\end{array}$ & $\begin{array}{l}\text { VEHY } \\
\text { HILH }\end{array}$ & IUN $260 \mathrm{~F}$ & coud & MOOERAIE & SOME & SOME & MIGH \\
\hline & $\sin x$ & $\begin{array}{l}1.200 \mathrm{TU} \\
4.000 \\
\text { fEE T }\end{array}$ & $\begin{array}{l}\text { GENEHALIY } \\
\text { AHGH }\end{array}$ & $\begin{array}{l}\text { ST WUMGEEI } \\
\text { OF } \triangle A Y \text {. } \\
\text { FiBI HS }\end{array}$ & $\begin{array}{l}\text { VEHY } \\
\text { HIGH }\end{array}$ & NEAT GOUO & $\begin{array}{l}\text { nos. } \\
\text { condouctich }\end{array}$ & EXCELLEMI & YEAYGO00 & VEHY GOOOO & $\begin{array}{l}\text { mouenare } \\
\text { To pour }\end{array}$ & moderate & $\begin{array}{l}\text { Mu JeAati } \\
\text { Juof. }\end{array}$ & 6000 & MGH & 6000 & SOME & EXCELLETT \\
\hline & Lumin & $\begin{array}{l}12 \text { TO2020 } \\
\text { IMLEIS }\end{array}$ & MlüH & $\begin{array}{l}\text { 2NU } \\
\text { SIRJMGEST } \\
\end{array}$ & LEASI & Elast & Btsr & low & veny gude & VEAY DOOOO & Vear GeOD & MIGM & Lon suor. & Low & 6000 & 6000 & None & POOA \\
\hline \multirow{11}{*}{ 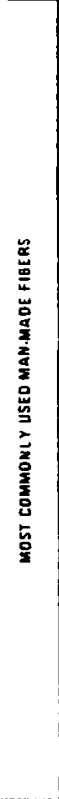 } & narum & VAHIABII & CONIAOLILO & $\begin{array}{l}\text { VENT } \\
\text { SIAJMG }\end{array}$ & Low & Jehriom & venticoon & Iuw & VEAYGOOD & mooehaIE & vaAiles & MILH & g00.390 r. & MIGM & vafues & MGH & MOME & 6000 \\
\hline & actiale & VAAILBLE & CONIHOLLO & com & 3000 & soop & low & idit & nugihait. & .0000 & PoOH & mourhate & $180 \equiv$ & MOOEHAIE & Low & MODERATE & nome & vaAlES \\
\hline & InIacelale & VAHIABGIS & $\begin{array}{l}\text { CONAROULEO } \\
\text { aAiGHT }\end{array}$ & $\begin{array}{l}\text { IIKE WUOU } \\
\text { WEAXEA } \\
\text { WHES WET }\end{array}$ & 2000 & Ienr cugo & Luw & FAIH & MUUEAAIE & Gous & poon & Law & $+100=$ & HESISIAMI & Low & moderate & MOME & 6000 \\
\hline & nrion & VAAISBCLE & $\begin{array}{l}\text { COMIROMLOU } \\
\text { EHIGHT }\end{array}$ & $\begin{array}{l}\text { MEI AIIVEIY } \\
\text { SIHEMG }\end{array}$ & 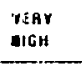 & -Earciogo & vahies & ExcGLIt & Low & 6000 & If AIM & Low & $200 \%$ & AE SISTANI & mooeraie & MIGH & raIA & ratA \\
\hline & poctresien & VAHHE.OLIE & $\begin{array}{l}\text { CONIHOLLO } \\
\text { BALHHI }\end{array}$ & $\begin{array}{l}\text { AtininveAY } \\
\text { SIACAG }\end{array}$ & $\begin{array}{l}\text { DEAY } \\
\text {. UWW } \\
\end{array}$ & MERYi COUU & FAIA & IAIA & Vehriow & 6000 & FaAR & Low & C501, & AESISTAANI & MOOEAaIF & HIGH & 6000 & 6000 \\
\hline & Aitrulc & VAhisGLE & $\begin{array}{l}\text { CONIHLLLO } \\
\text { BRIGHI }\end{array}$ & $\begin{array}{l}\text { VAHAS - } \\
\text { MOO:H. } \\
\text { STHGNG } \\
\end{array}$ & IIIrLE & VEHYGOOD & Lom & $\begin{array}{l}\text { VAAIES } \\
\text { IAIA }\end{array}$ & LuW & $\begin{array}{l}\text { GOOD ro } \\
\text { veAY GOOD }\end{array}$ & FAIR & Low & Nucosur. & AESSISIAMT & VEAY LOW & $\begin{array}{l}\text { BAAR TO } \\
\text { G000 }\end{array}$ & 6000 & $\begin{array}{l}\text { VAAHES WIIH } \\
\text { IYPEE }\end{array}$ \\
\hline & MDUACHYIIC & VAHIDegeic & $\begin{array}{l}\text { caminouteo } \\
\text { eanint } \\
\end{array}$ & coon & wirlit & WaYGGOOD & tow & $\begin{array}{l}\text { VaAGIS } \\
\text { inA } \\
\end{array}$ & $\begin{array}{l}\text { Luw } \\
\text { LARIISS }\end{array}$ & $\begin{array}{l}\text { GUOU IO } \\
\text { VERY GOOD } \\
\end{array}$ & JaHILS & Luw & $\mathbf{z o}_{0} \mathrm{~F}$. & HESISI AWT & Low & 6000 & 6000 & moderate \\
\hline & SPANUEC $x$ & VAAIABIE & oust & low & $\begin{array}{l}\text { RoST } \\
\text { BASIII } \\
\end{array}$ & WaY hIG & 6000 & VEHY GO00 & VeHYIOW & VEAY GOUD & JAHIES & Low & $130 \mathrm{~F}$. & HESISTAMY & moothaIE & $\begin{array}{l}\text { POOA IO } \\
6000\end{array}$ & $\begin{array}{l}\text { POOA 10 } \\
\text { GOOD }\end{array}$ & 0000 \\
\hline & SpaAan & VARIABLE & semivurat & $\begin{array}{l}\text { VEHY } \\
\text { SiHONG } \\
\end{array}$ & 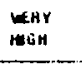 & 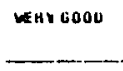 & tow & ION & $\begin{array}{l}\text { MUN. } \\
\text { AESUHQENI }\end{array}$ & ciouo & $=$ AIR & low & nof & HESISTAMT & Low & 6000 & $\begin{array}{l}\text { FAIA IO } \\
\text { GOOD }\end{array}$ & UMCHAMGEABIE \\
\hline & ULASS FIBEM & VAFIASII & $\begin{array}{l}\text { CONIHULLEU } \\
\text { BRIEHT }\end{array}$ & STHONGESE & LANE & $\begin{array}{l}\text { REL LATIVESY } \\
\text { IaGH }\end{array}$ & 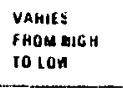 & $\begin{array}{l}\text { jood } \\
\text { vaAlES }\end{array}$ & $\begin{array}{l}\text { MCN. } \\
\text { AasoABENI }\end{array}$ & EXCELLENT & AIH & low & conos. & RESISI AMT & NOME & MOOEAATE & 0000 & COMpLicateo \\
\hline & & & & & & & & & & & & & & & & & & \\
\hline
\end{tabular}


FIGURE 3-1

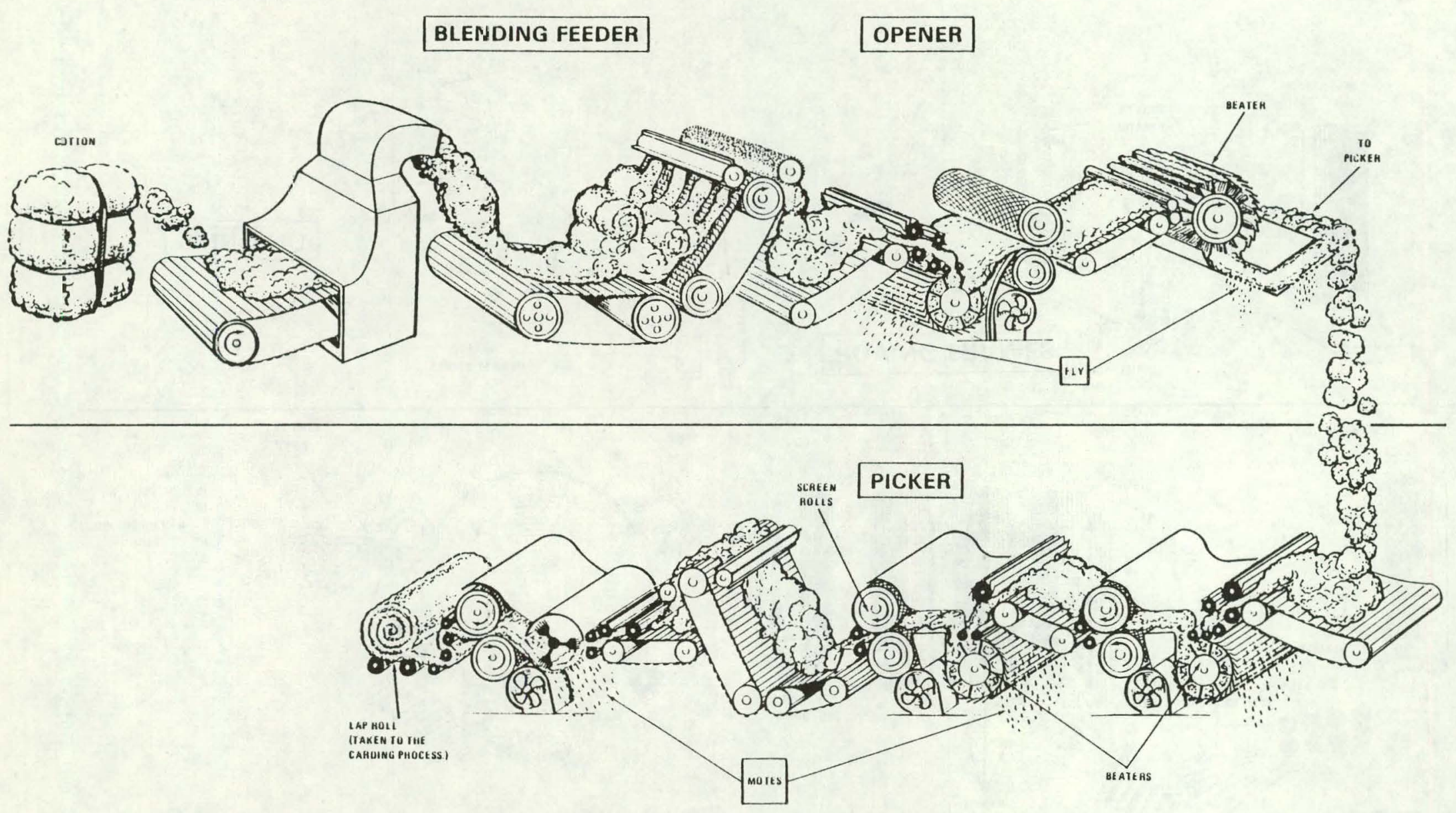




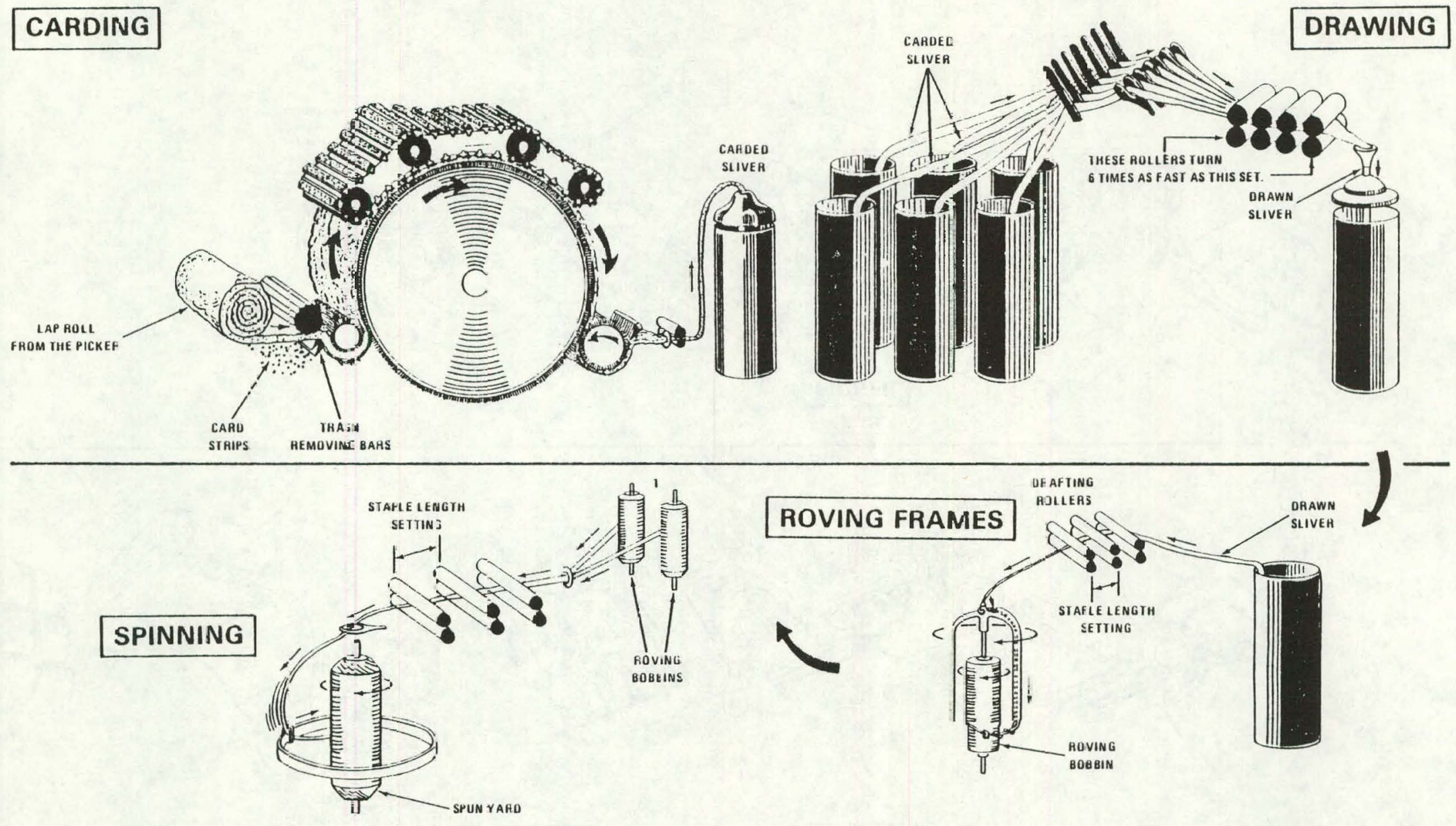


cotton through a number of different beating and air suction operations. This process also loosens, limps, and fluffs-up the fibers. In blending, contents of many bales are mixed to attain a degree of uniformity. Most companies blend several ( 4 to 42 ) bales simultaneously to obtain a wellbalanced blend and to achieve desired fiber characteristics in fiber maturity and fiber length-micronaire. The picking process further opens and blends the fibers. Fibers in the pickers pass through several beaters and screen rolls into a lap roll. (A lap roll of cotton is about 40 inches wide and 10 inches in diameter; it contains layers of 1 -inch thick cotton laps.) The opening, blending, and picking processes were shown in Figure 3-1. The waste generated by these processes are referred to as motes and fly.

\subsubsection{Carding Process}

In the process called carding, fibers are cleaned and arranged in parallel order. Cleaning removes large amounts of waste, tangled fibers, and short fibers. Short fibers are removed to make subsequent operations (drawing, roving, and spinning) go more smoothly. Removing the shorter fibers also produces or improves such yarn characteristics as high tensile strength, smoothness, and resilience. The resulting clean and parallel cotton fibers are drawn out of the card in sliver form into a sliver can, as shown in Figure 3-2.

\subsubsection{Drawing Process}

In the drawing process, six, eight, or more slivers are combined into one in order to obtain higher uniformity of fibers, more parallel fibers, and uniform blending of different fibers such as polyester. A drawiny frame is used to combine and pull slivers; generally, the resulting sliver is as thick as the original, but proportionally longer. For example, six slivers are combined, the resulting drawn product is six times longer. The process is illustrated in Figure 3-2.

\subsubsection{Lapping and Combing Process}

Lapping and combing are two additional steps used in producing higher quality yarns. The lapping processes flatten 
the sliver into an approximately 8-inch wide strip, while the combing process involves the removal of short fibers. The combing waste is known as comber noils. The combed cotton possesses greater strength and a higher luster than its noncombed counterpart making possible the production of finer cotton yarns.

\subsubsection{Roving Process}

The roving process reduces the diameter of the drawn sliver, strengthens and tightens the sliver, and imparts the first twisting action. This proress invmlves the use of consecutively-positioned drafting rolls, each set turning faster than the preceding pair. The spacing of the rolls are designed to be a fraction of an inrh longer than the longest average fibers used. It longer fibers penetrate the process, they may be torn by the rollers; whereas shorter fibers can cause ends-down (stopping the yarn-forming process) or lumping between the rolls. Ends-down have an adverse effect on the economics of textile production, while lumping causes unevenness or damage in yarns. The roving process is illustrated in Figure 3-2.

\section{$3.1 .2 .6 \quad$ Spinning Process}

Spinning is a combination of drawing and the simultaneous application of a twist to the drawn roving. The drawing process is similar to that of roving although designed to produce a tiner and stronger product. The twisting is applied to create a permanent hold of the fibers and to supply strength. In general, the spinning process can influence such yarn characteristics as appearance, durability, softness, strength, and serviceability.

\subsubsection{Production of Woolen Yarns}

Woolen yarns are more complicated to produce than cotton yarns. This is because of the variety of grades of wool in the bale and the high level of contaminants in the fleece, requiring careful grading and wet preparatory treatment. Some of the steps in wool yarn production are described in the following paragraphs. 


\subsubsection{Grading and Separation of Wool}

When the wool reaches the mill, it contains the fleece of several sheep. Each fleece contains different grades of wool requiring careful manual grading and separating of groups of fibers according to length, diameter, and quality. The grading and separating process is performed by skilled workers, expert in wool identification.

\subsubsection{Cleansing and Treating of Wool}

The production of wool yarn is further complicated by various cleansing and treating operations. Some of the preparatory operations are wet processes designed to cleanse the wool from suint oils and other foreign particles. The most commonly. used preparatory processes are shown in Figure 3-3.

\subsubsection{Yarn Formation From Man-llade Fibers}

Forming yarn from man-made fibers is much simpler than forming it from either wool or cotton. This is primarily due to the purity and uniformity of man-made fibers, characteristics that permit the elimination of the various cleaning prociesses. In other aspects, yarn from man-made fibers is similar to forming it from cotton. However, because of the great variations within man-made fibers, some steps in yarn formation are still peculiar to these materials.

\subsubsection{Continuous Filament Fibers}

In the case of continuous filament fibers, the yarns can be formed by twisting several filaments (the number of filaments varies, but 32 and 64 are common). Often, continuous filament yarn is produced by chemical industries manufacturing the filament. A flow diagram of the process for producing man-made fiber yarn is shown in Figure 3-3.

\subsubsection{Treatments for Man-Made Fibers}

Many man-made fibers are often treated to create new surface, shape, and texture characteristics; these steps 
FIGURE 3-3

Major operations in Man-ptade, cotton and woolen Yarn Forining processes

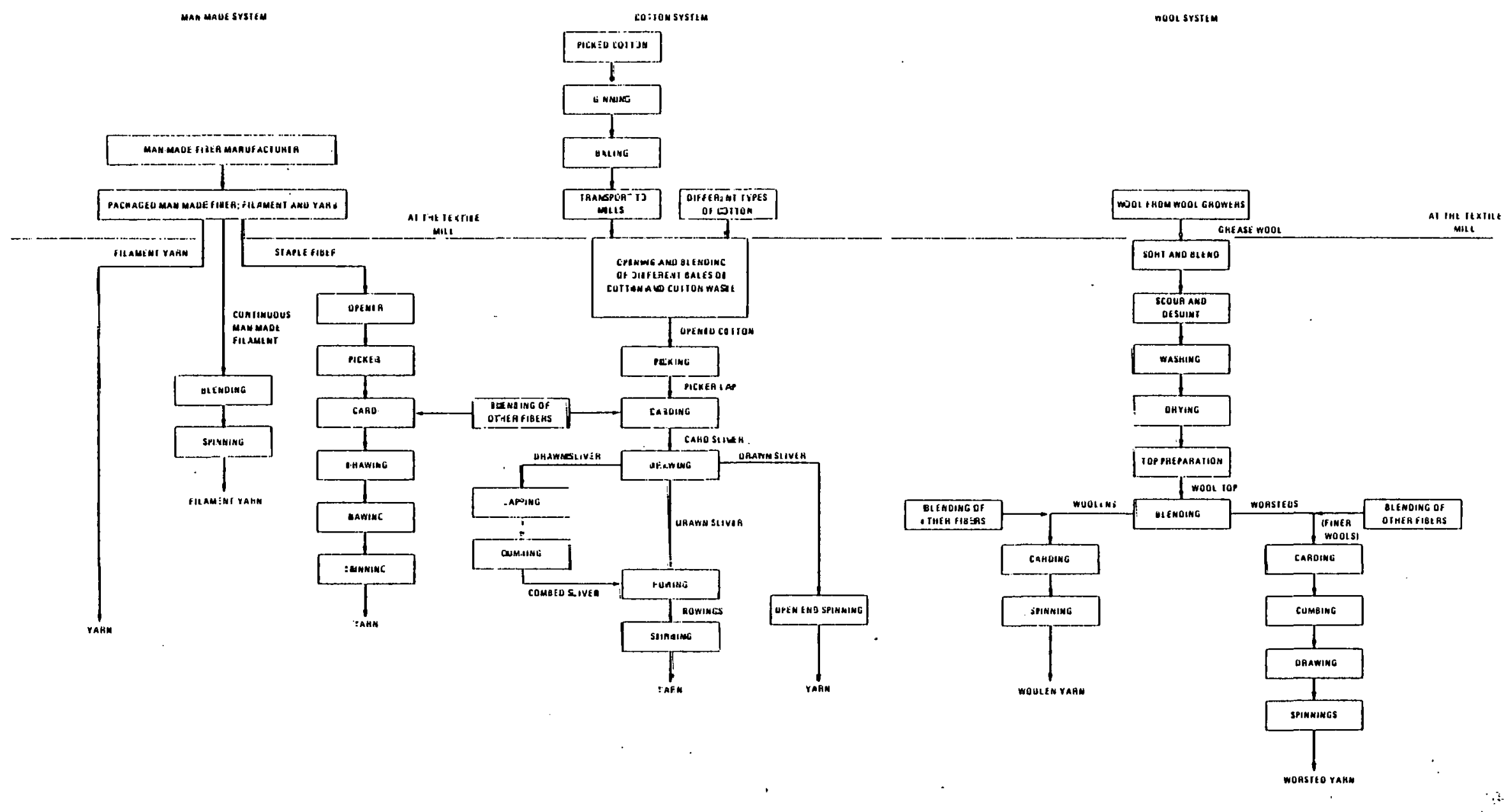


are taken to provide consumers with desired yarn or fabric properties. The fiber treatments are known as texturizing. Some common fiber characteristics that can be obtained through texturizing are elasticity or stretch, high bulk, and loop bulk. Textured man-made fibers are produced through mechanical heat-setting operations on the thermoplastic filament fibers. In the case of continuous filament yarns such as rayon, nylon, or polyester, texturizing processes are applied to simulate the appearance and feel of natural fibers.

\subsubsection{Textile Fabric Formation}

Fabric is formed by connecting yarn made of fibers into flexible sheets of textile materials. There are three major fabric-forming processes-weaving, knitting, and nonwoven processing. The general characteristics of these processes are discussed in the following paragraphs.

\subsubsection{The Weaving Process}

Weaving consists of the interlacing of warp yarn with crosswise fill yarns. The warp yarns must undergo treatments (sizing), which do not improve the quality of the yarn, but prepare the yarn for the strain of weaving. After treatment, the warp yarns are set into the loom (weaving machine) in an arrangement determiried according to the desired designs and fabric characteristics. Characteristics, advantages, and limitations of the basic weaves are given in Table 3-3.

\subsubsection{The Knitting Process}

Knitting is a process of fabric construction achieved by the interlooping of yarns into a series of connected loops. Knitting machines can form hundreds of loops at a time and have the capacity to create different knitting designs. The outstanding characteristic of knitted fabrics is their exceptional stretchability which can be achieved even from nonstretchable yarn. Knitted goods are also known to have good insulating qualities, high levels of absorbency, high weight, and wrinkle resistance. 
TABLE 3-3

Characteristics, Advantages, and

Limitations of Basic Meaves

\begin{tabular}{|c|c|c|c|}
\hline WEAVE & CHARACTERISTICS & ADVANTAGES & LIMITATIONS \\
\hline PLAIN & $\begin{array}{l}\text { NO DISTINCT DESIGN } \\
\text { UNLESS YARNS HAVE } \\
\text { CONTRASTING COLONS }\end{array}$ & $\begin{array}{l}\text { MAXIMUM YAROAGE; } \\
\text { EASILY PRODUCED; INEX. } \\
\text { PENSIVE; STRUNG; } \\
\text { ADAPTABLE FOR DIRECT } \\
\text { PRINTING ANŌ U I HEK } \\
\text { FINISHING PROCESSES }\end{array}$ & $\begin{array}{l}\text { SLEAZY FABRIC IF THREAD } \\
\text { COUNT IS LOW }\end{array}$ \\
\hline BASKET & BASKET PATTERN & $\begin{array}{l}\text { ATTRACTIVE; INEXPEN. } \\
\text { SIVE; DRAPABLE; } \\
\text { ABSORBENT }\end{array}$ & $\begin{array}{l}\text { NOT OURABLE FOR } \\
\text { APPAREL; SOILS EASILY }\end{array}$ \\
\hline RIBBED & CORDED EFFECTS & ORNAMENTAL & $\begin{array}{l}\text { NOT SERVICEABLE IF OF } \\
\text { INFERIOR CUNSTRUCTION }\end{array}$ \\
\hline TWILL & $\begin{array}{l}\text { DISTINCT DIAGONAL } \\
\text { OESIGN }\end{array}$ & $\begin{array}{l}\text { STRONG, FIRM TEXTURE; } \\
\text { INCREASED ORARAOILITY; } \\
\text { INTERFSTING OESIGNS }\end{array}$ & $\begin{array}{l}\text { REQUIRES CARE TO KEEP } \\
\text { LLLAN: DEVEI NPS SHINE }\end{array}$ \\
\hline SATIN & $\begin{array}{l}\text { LUSTER; INTERRUPTED } \\
\text { OIAGONAL DESIGN } \\
\text { OISCERNIBLE WITH } \\
\text { MAGNIFYING GLASS }\end{array}$ & $\begin{array}{l}\text { 8EAUTY CONTRIBUTED BY } \\
\text { LUSTER: SMNTTH: } \\
\text { MAXIMUM ORAPABILITY }\end{array}$ & $\begin{array}{l}\text { EXCESSIVELY LONG FLUATS } \\
\text { MAY ONAO AND RUULHEN } \\
\text { FABRIC }\end{array}$ \\
\hline
\end{tabular}




\subsubsection{The Nonwoven Process}

The nonwoven method of production refers to the creation of a textile product directly from fibers without the use of yarn. Instead chemical bonding agents and/or physical means of bonding are used. The nonwoven manufacturing system is based on four basic processes, each of which can be done in different ways. The four basic processes and the various methods of performing each are as follows:

- Fiber preparation can be achieved through opening, conditioning, blending, and chip preparation

- Web forming is done through card or garnett laying, air laying, or web laying.

- Web bonding is the actual fabric forming process, performed through such operations as point bonding, print bonding, needle punching, or, jet entanglement.

- Some post-treatment operations include drying, curing, finishing, printing, and dyeing.

A particularly attractive characteristic of the nonwoven approach is its simple fabric-forming operation. Such time consuming processes as drawing, roving, spinning, weaving, and knitting can be omitted and various other mechanical and chemical operations are also not needed. Nonwoven textile items are low in cost, in great part because they can be produced simply and quickly. However, certain desirable fabric characteristics cannot as yet be obtained. The product has little tensile strength and little or no elasticity or drapability. However, certain non-wovens have high thermal insulating properties. Because of their lack of desirable characteristics, nonwovens are used primarily in non-outerwear and second tier textile goods.

Tufting is the process of punching extra loops of yarn into a woven fabric. The tufts are generally created perpendicular to the primary backing, which adds a desired third dimension to such fabrics as carpets, chenille bedspreads, and bathroom mats. The yalin most often user in tufting is made from continuous filament to ensure smooth operation and maximum strength. In carpets, where there is much abrasion, the backing is coated with latex to hold the tufts. (The latex backing forms a permanent and irreversible bond which makes the reprocessing of carpet waste impossible at this time.) 


\subsubsection{Textile Finishing Processes}

In the textile industry, finishing is an important and complicated process. It has many forms and they must be adapted to the kind of fiber and yarn used in the fabric. More important,. the finishing must be adapted to the fabric's intended purpose. In order to obtain predictable and desirable qualities through finishing, the type of fiber or fibers in the fabric must be identified. (The implication of this requirement for the use of recovered materials is critical and will be discussed further.) There are many imporldnt textile tinishing processes and the predominant effect of earh on variouo tcxtile luill produrts has been a seerlailled, bue hew tinishing processes are being developed each year. Some of the more prevalent finishing processes currently used are discussed below.

\section{$3.1 .6 .1 \quad$ Singeing}

Singing or gassing is the removal of lint, fuzz, thread, and fiber ends by burning with a gas flame to obtain a smooth, clean finish. This finishing technique is often used for fine-quality yarns.

\subsubsection{Bleaching}

Bleaching is the removal of color, stains, or discolorations from the fabric or yarn prior to dyeing, pringing, or othor finishiny. Bleaching ensures a consistent nptake of dye by lie fabric. The fiber content of the product must be known because a bleach reacts differently to different types of fibers.

\section{1 .6 .3 Mercerization}

Mercerizintinn is the passiliy of a fabric through a cold 15 to 20 percent solution of caustic soda. The soda solution is later removed from the fabric. Mercerization is used only for cotton and it inrreases thc luster, strength, and body of the fibers and yarn. It also increases the product's affinity for certain dyes.

\section{1 .6 .4 Slack Mercerization}

Slack mercerization is the process of soaking and stretching the fabric in the caustic soda solution for 
approximately 1 minute. This process, which is used only for cotton, adds 15 to 20 percent stretch to the fabric. It also increases the abrasion resistance of the fabric by approximately a multiple of four. In this process, the fabric's strength is reduced by 30 to 50 percent.

\subsubsection{Shrinking}

Shrinking is using water, steam, or chemicals to reduce the size of the fabric. It counteracts the extra, unnatural length gained through the continuous application of tension during fabric production. Shrinking methods vary with fiber type and fabric construction.

\subsubsection{Tentering}

Tentering is a process for drying the fabric, evening its weight, and aligning the filling yarn perpendicular to the warp yarn.

\subsubsection{Temporary Stiffening}

Temporary stiffening is the immersing of fabrics in a solution of starch to add stiffness, weight, strength, and a preservative. Other temporary additives are oils, flour, glue, etc.

\subsubsection{Permanent Stiffening}

Permanent stiffening can be obtained by chemical processes that change the cellular structure of the fiber. This is done to achieve stiffness, smoothness, permanency, and soil resistance.

\subsubsection{Calendering}

Calendering is essentially an ironing process designed to add eheen to the fabric. The effect is achieved by passing the fabric between large, heated rollers. When calendering is performed on a fabric treated with temporary stiffening agents, a stifi polishea, or glazed surface is obtained. 


\section{1 .6 .10 Napping}

Napping produces a fuzzy finish through combing. The process is used to obtain a desired feel, warmth, and serviceability. The yarn intended for napping is loosely spun to make napping easier. A shearing process is used to even yarn irregularities.

\subsubsection{Shape-Retentive Finishes}

Shapc-retentive Iinishes prevent deformation of the fabric from unintentional wrinkling. Thocc finishes ate a.l.L sbtainod through tlie use uf resins or reactants that combine chemically with the fiber. Side effects of some shape-retentive finishes are a considerable loss in strength, absorption, and comfort.

\section{1 .6 .12 Other Finishes}

Many other finishes can be applied to textile fabric, for physical or chemical finishing. However, the remaining finishing processes, dyeing and printing, are applied to most textile mill products.

Dyeing is a complex process designed to enhance the appearance of the tabric. Its complexity arises from the nonhomogeneous nature of the fibers, the effect of finishing operations, and the high sensitivity of dyeing to changes in dye mix. Selecting the proper dye is extremely important, but it is also quite difficult. This is because new dyes have been introduced and there are also new fibers, now fiber blends, llew flnishing processes, and a demand for new color tones.

Some classes of dyes, their uses, and characteristies are listed in rable $3-4$.

Printing is an alternative way to decorate fabrics. There are different methods of printing, a few of which are as follows:

Block printing employes blocks designed to print smal, 1 areas at a time. This form of printing is in limited use.

- Roller printing is a continuous multicolor process. 
TABIE: 3-4

Selected Dye Classes, fheir uses, and Characteristics

\begin{tabular}{|c|c|c|c|c|c|c|c|c|c|c|c|}
\hline$i_{\cos 43}$ & $\begin{array}{l}\text { citumat } \\
\text { actscatertion }\end{array}$ & 4215 & $f_{\text {. } \ldots \mathrm{mm}}$ & mosuma & 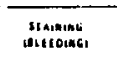 & anrcicuaming & mot mes sists & chuicing & Gastaunc & manactan & mesmanation \\
\hline ansic & $\mid$ & 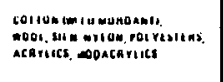 & 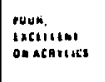 & 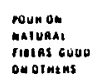 & 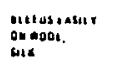 & 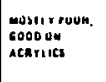 & |ctistitas & 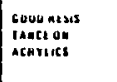 & -oo suscromase & 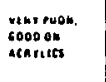 & 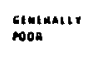 \\
\hline Dastin & 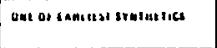 & 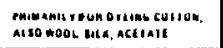 & 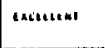 & venr coou & viar covos & venr govu & - oo atristio & Vats cooo & eus luscheriast & Mol artestito & sovu \\
\hline$\$+10$ & 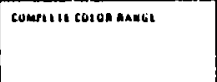 & 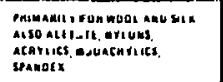 & 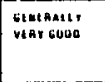 & roun & 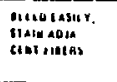 & soug & .01 anticite & arcalutur & 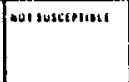 & ians. & rasin \\
\hline 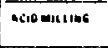 & 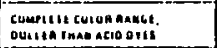 & SAet AS ACD & 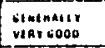 & sovo & 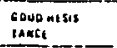 & Gous & outarecises & incticus & 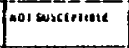 & 8000 & risen 1000000 \\
\hline sum nusuc & 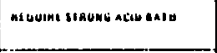 & 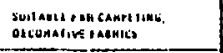 & 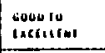 & rasin 10 wues & 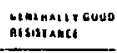 & c000 & nor atricieu & 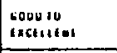 & Dot esscrisuate & inen tus sous & soou \\
\hline 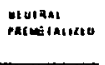 & 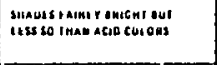 & 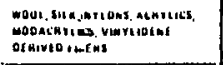 & 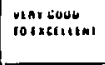 & $\tan 1006000$ & 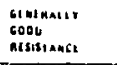 & couve & mor atretile & 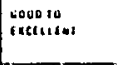 & Auratitcito & 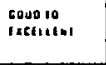 & 6000 \\
\hline 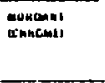 & 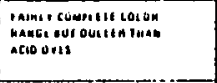 & 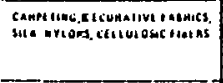 & $\begin{array}{l}\text { soun ro } \\
\text { inctintas }\end{array}$ & sous & 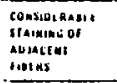 & anim 106000 & sor ancicitue & inan 106000 & -ooserictio & 6000 & $\begin{array}{l}\text { fenchanar } \\
\text { cooo }\end{array}$ \\
\hline $\begin{array}{l}\text { sulsmanive } \\
\text { sistá }\end{array}$ & 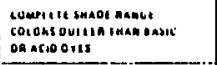 & 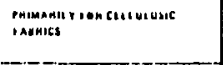 & 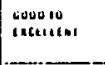 & num & 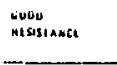 & c000 & c000 & 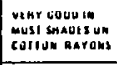 & |woralicitio & Pusa iv soou & coov \\
\hline Nevisorte & 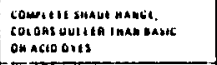 & Samt as susi andive Uris & $\begin{array}{l}\text { cosu } 10 \\
\text { ixcilitint }\end{array}$ & rain & 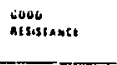 & cuado & 6000 & 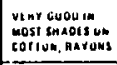 & 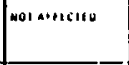 & Poun to bouv & 0000 \\
\hline ston & 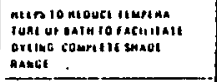 & 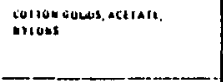 & $\begin{array}{l}\text { covo } 10 \\
\text { ixclatitus }\end{array}$ & 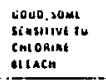 & 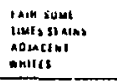 & w000 & 6000 & 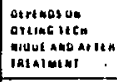 & mur aisticitev & ovou . & $\begin{array}{l}\operatorname{ciminanicy}_{\cos } \\
\cos \end{array}$ \\
\hline usetist & 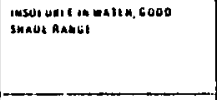 & 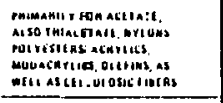 & 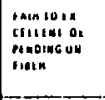 & $\operatorname{ranh} 106000$ & Maumsnoor & 0000 & 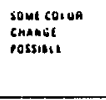 & 6000 & 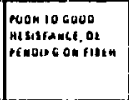 & 1000 & 0000 \\
\hline sulion & 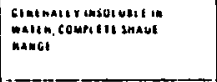 & 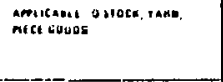 & 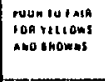 & 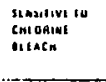 & 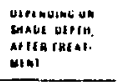 & toou & 10000 & $\begin{array}{l}\text { roun } \\
\text { coud }\end{array}$ & Pur atricieo & 6000 & 6000 \\
\hline van & 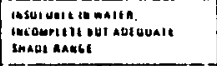 & 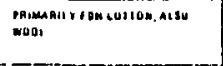 & 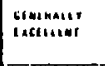 & touo & $\begin{array}{l}\text { couo } \\
\text { natislancit }\end{array}$ & 6000 & 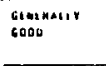 & isin 10 toou & 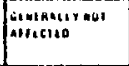 & 6000 & 6000 \\
\hline Antriout & 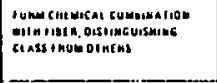 & 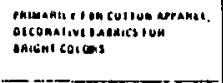 & $\begin{array}{l}\text { Luod io } \\
\text { vent cous }\end{array}$ & 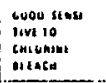 & 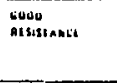 & 6000 & voraticitos & 10000 & Doul suscertastit & $\begin{array}{l}\text { cuoou som } \\
\text { rath }\end{array}$ & 6000 \\
\hline rewal ul & 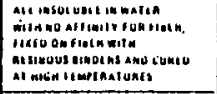 & 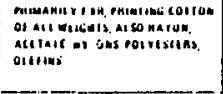 & 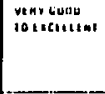 & voou & savo & coud & 6004 & 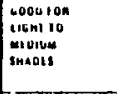 & 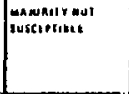 & 6000 & 5000 \\
\hline urritentus & 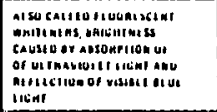 & 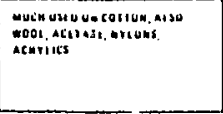 & inin & vaniss & 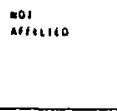 & 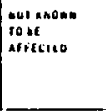 & 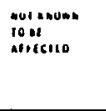 & 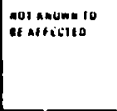 & 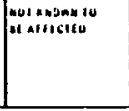 & 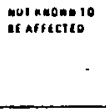 & 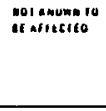 \\
\hline
\end{tabular}

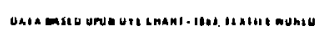


- Duplex printing simultaneously prints both sides

- Discharge printing displaces the dye on a dyed fabric to obtain such effects as polka dots.

As indicated by this overview, textile operations are a complicated series of technical processes that are highly dependent on the quality in input fibers. The characteristics of the final output are influenced by each of the operations and the acceptability of final products is determined by the control exercised over these operations.

\subsection{NO TECHNOLOGIES ARE NOW AVAILABLE TO PREPARE TEXTILE VASTE FOR USE IN MAKING FIRST TIER YARN AND FABRIC}

Less than 1 percent of the fibers consumed by the textile mill products industry are not used in some way. This means that only about 100 million pounds go unused, in spite of the fact that individual processes may generate unused iibers at rates up to 25 percent of total input. Raw material control in the textile mill products industry is pervasive because the industry is operating on a low profit margin and raw material constitutes 40 to 60 percent of total product cost. As previously indicated, operating personnel make great efforts to reprocess waste by cycling such by-products as comber noils and motes back into the system. Waste that cannot be used by the upper tier mills are generally sold either to textile waste reprocessors or to mills that produce second tier textile products. The by-producls are reprocccecd in various ways, but they cannot be upgraded for use by the first tier textile mills.

\subsection{J. Fibrous Haste Reprocessing}

Reprocessing fibrous material involves identification, grading, cleaning, carding, blendlng, all] Laliny it. If the waste product is not clearly identified by the supplier, the reprocessors usually examine the waste visually to ietermine its quality. Some larger reprocessors may use more scientific methods such as burning tests, microscupic analysis, and chemical tests. When the waste is identified and graded, it is stored until shipment to a user in the second tier of the textile industry. Before shipment, the waste is moved into the reprocessing area for preparation according to the buyer's specifications. 
Heavily-contaminated waste such as sweep waste is emptied onto a conveyor belt where it is manually examined and cleaned. Magnets are sometimes used to remove metallic impurities. After the waste is sufficiently cleaned of major impurities, it enters a hopper feeder.where heavy impurities are removed. At this stage the waste is still contaminated with dust and smaller particles of waste.

To further purify the product, reprocessors beat and mix it in a step cleaner, thus loosening the impurities. The loosened product is ready to be processed through conventional cleaning machines, resembling the opener, picker, and card used in first tier textile mills. This purifying and cleaning process is known as willowing. (Willowing creates much cotton and fiber dust, a problem treated in the OSHA Cotton Dust Standards.) The willowing process is often accompanied or followed by a blending process similar to the blending operations at first tier textile mills. This process is used to obtain a desired fiber mix.

\subsubsection{Yarn Waste Reprocessing}

Yarn waste reprocessirg operatiors jnclude sorting, chopping, and shredding. The various yarns are handled as follows:

The longest cords are sold to cordage manufacturers.

- Second longest cords are sold to string mop manufacturers.

- Cords too short for use as yarn are chopped into small lengths, shredded, and picked into a fiber form (with some stray yarn), termed "shoddy," and sold for use in the production of some coarse yarns. The coarse yarns are formed into such items as industrial mats and floor mops.

Many buyers of reprocessed yarn specify the fiber content of the product. Certain buyers also request that the product not contain chemical contaminants. In order to meet these specifications, the reprocessors pay considerable attention to identifying and sorting the yarn into various quality and fiber groupings. The sorting process is performed manually on conveyors or sorting tables. The selected yarns are cut into shorter lengths 
by guillotine cutters or rotary cutters. The cut yarn, usually between $1 / 3$ and 3 inches long, is conveyed to a shredder that is designed to delump, tear, and open yarn and fabric waste. Shredding is accomplished in one or more main cylinders, equipped with special shredding pins. The speed of the cylinders and the size and density of the pins determine the extent to which the yarn can be opened, fluffed, and delumped.

Products such as wool or rayon that are intended for respinning can be further refined through a process known as garnetting. Garnetting makes shredded materials

sufficiently fibrous that they are not detrimental to the carding operation. The garnett operates like a shredder, except that its cylindcr ic lined with garnetting wires instead of pins. The wires resemble the teeth of a saw.

\subsubsection{Fabric Vaste Reprocessing}

Fabric waste is reprocessed for use in the secund tier of the industry through mechanical processes very similar to those used in reprocessing yarn waste. The identification and sorting operations are time-consuming manual processes, but they ensure a certain degree of fiber and quality control.

The sorted fabric is cut by mechanical or hand cutters into pieces small enough to feed into the rag picker. Rag picking is a tearing and shredding process employing heavy rotating cylinders equipped with forged teeth. The various forged teeth available for the rag picker are designed to tear, cut, and shred the fabric.

The picked (torn) fabrire is conveyed on air blowers to a separator for elimination of heavy particles such as zippers and buttons. The reclaiming processes that follow separation are identical to the processes employed in yarn waste recovery.

These types of textile waste are currently being processed in the waste products subsector of the industry (SIC 2294) and they are used throughout the second tier of the textile mill products industry and in other industrial applications. However, there are no processes currently available to upgrade this waste for use in the making of products in the first tier of the industry. 
3.3 NO TECHNICAL DEVELOPMENTS FOR IMPROVING THE USE OF REPROCESSED TEXTILE WASTE ARE AUTTICIPATED BEFORE 1987

Several important technological developments are expected to influence the generation of waste in the textile mill products industry. These developments are as follows:

- Automatic waste collection systems designed to control dust and waste at the textile mills

- Open-end spinning systems which use more short fibers in the production of yarn

- Growth of the nonwoven method of fabric formation which can use waste fibers in some applications.

\subsubsection{Automatic Maste Collection}

Waste generated during the yarn production process will be handled by automatic collection devices designed to pneumatically collect, transport, grade, and bale all waste generated during the yarn preparation process. One such system is being produced and installed by the Pneumafil Corporation. Systems such as those developed and installed by Pneumafil have been designed for the elimination of cotton dust from the air. The value of the system in waste collection is its ability to collect and sort all the waste generated at the spinning plant. Some systems can be equipped with waste-grading equipment designed to sort waste into three categories-reworkable waste, salable waste, and disposable waste.

Since pneumatic systems require closed yarn preparatory operations, all floor-sweep fibrous waste will be eliminated. This system is expected to reduce slightly the amount of generated cotton wastes and to reduce the quality of the salable cotton waste.

The technical feasibility of this process has been established in several installations in Europe and the United States. The number of operations of such a1r quality and waste control systems should increase substantially over the next few years due to the requirements of the OSHA cotton dust standards. 


\subsubsection{Open-End Spinning}

Open-end spinning is another established technology that will influence the generation of waste in the textile mill products industry. Open-end spinning systems spin yarn directly from sliver (see Figure 3-2). The removal of short fibers during carding and picking is partially designed to reduce the "ends-down" during the conventional spinning process (e.g., drawing and roving). However, open-end spinning systems are destined to spin yarn directly, skipping the drawing and roving process. Consequently, compared with ring spinning, open-end spinning Eyctcms can use more of the short fibers. Open-end spinning systems have arditional advanlayes, such as the following:

- Require one-half to one-third of the normal floor space per pound of output

- Consume up to 30 percent less energy per output, depending on product type

- Minimize pollution in the working environment because of the system of yarn preparation

- Have higher speeds of production

- Result in more esonomis production for low-count yarns.

Some of these advantages are offset by the following,

- High cost of the system

- Different physical characteristics of the yarn, such as low tensile strength

- Tncreased number of ends-duwn during weaving

- Higher level of pollution during subsequent operations due to the higher number of short fibers in the yarn.

Open-end spinning was developed in Europe during the early 1960's and became available in the United States in the mid-1960's. By 1976, there were 168,792 open-end spinning frames in the U.S. textile mills, representing approximately 2 percent of the total U.S. spinning capacity. An estimated 350,000 open-end spindles will be operating in the U.S. by the end of 1979, based on the Treasury Department's growth rate of 60,000 units per year. 
There are no composite forecasts available on the 1987 openend spinning capacity. Textile industry experts believe that 20 to 25 percent of all U.S. spinning may be done on open-end spinning machines by that time. Assuming a 20 percent capacity penetration of the open-end spinning process, its effect on waste is estimated to be as follows:

- Reduction in quantity and quality of reworkable waste

- Reduction in quantity and quality of salable waste

- No effect on disposable waste

- Increase in quantity of yarn waste due to weaving problems (looms-down)

- Increase in the amount of post-consumer waste, due to poor wear characteristics.

Open-end spinning is expected to reduce the overall quality and quantity of waste generated by the first tier textile mills. However, this reduction in fibrous waste may be offset by the increase in secondary (post-consumer) waste.

\subsubsection{INonwoven Fabric Production}

Recent developments in the production of nonwoven textile products and in the development of man-made fibers are responsible for the phenomenal growth of nonwovens. In the 2 years between 1975 and 1977, nonwoven consumption has grown from 508 million pounds to 641 million pounds (a 26 percent incrcase). Foren.ast.s by the trade association of the nonwoven fabric industry - the International NonWovens and Disposables Association (INDA) -indicate further growth from 641 million pounds in 1977 to 815 million pounds in 1981 (a 27 percent increast). Sales of these fabrics are expected to grow 8 to 20 percent per year, depending on the process and markets.

The nonwoven production system generally includes four basic steps-fiber preparation, web formation, web bonding, and post-treatment. Technically, the process is capable of using most types of fibers including fibers with short staple lengths. However, the properties of the 
individual fibers are transmitted into the properties of the fabric. As in the production of standard textile products, desired fabric characteristics are attainable only through effective fiber control. Investigations indicate that expanded use of nonwovens will cause more short length fibers and more irregular fibers to be used. This will result in competition between producers of nonwoven goods and other users of waste fibers for the limited and shrinking supply of waste fibers. However, since approximately 40 percent of nonwovens are disposable goods, secondary waste will increase.

\subsection{4 nverall Effects of Anticlpated Technolngisal Changes}

Discussions with textile waste dealers and nonwoven manufacturers indicate that technological change is expected to have two overall effects:

- Moderate reduction in the amount of salable, textile-mill-gencrated wasle

- Marked reduction in the quality of saluble, textile-mill-generated waste.

Because of the anticipated decrpase in the supply uf salable waste, the second tier textile mills will seek alternate sources of cheap materials. These sources include imports of textile mill waste and increased use of garment industry waste and nonfiber wastes.

Investigations did not uncover any waste reprocessing technoloqy that wrold influeive ur alter the present mode or level of textile waste utilization by 1987. Faster and more automated waste recovery systems have been developed in Europe and their functions and methods of operation are identical to thuse machines developed at the turn of the century.

In the early 1970's, various European institutions, such as the Shirley Institute and Leeds Inivereity in. England tried to dcvelop fiber-separating equipment. Such equipment would make it possible to use certain blends by separating and sorting the individual fibers. Two methods of fiber separation were examined:

Solvent extraction is a method of chemically separating loose fibers from a blend. Solvents 
would react with and dissolve one of the fiber types in the blend. Because of the complicated chemical parameters created by the various treatments and blends of man-made fibers, solvent extraction did not develop into a marketable process.

Electrostatic fiber separation is based on the fact that different electrical charges are generated by various fibers. In experimental operations, a 98 percent fiber separation was achieved. However, the process was plagued with numerous problems, both mechanical and economic; and the development of the system was suspended.

These technologies are not expected to have any impact. on the waste recovery process prior to 1987 unless extensive research programs and agressive development programs are implemented. Presently there is no evidence that such programs will be forthcoming.

*

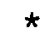

*

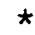

$\star$

Technical processes currently used or anticipated were discussed in this chapter. The following chapter will examine the economic environment in which the textile mill products industry operates. 


\section{CHAPTER 3 SOURCES}

1. American Textile Manufacturers Institute, Textiles From Start to Finish.

2. Conversations and correspondence with representatives of the following assuciations:

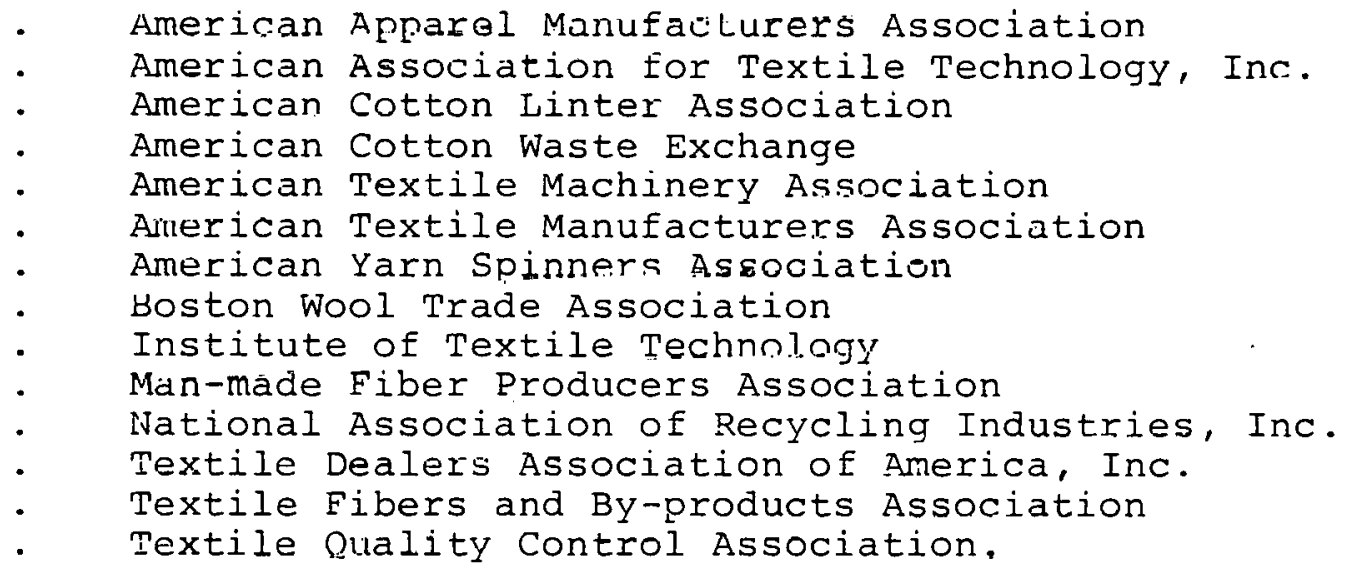

3. Conversations with representatives of the following government agencies:

Department of Agriculture
Office of Textiles (U.S. Department of Commerce)
Patent Office (U.S. Department of Commerce).

4. Conversations with textile experts from the following institutions:

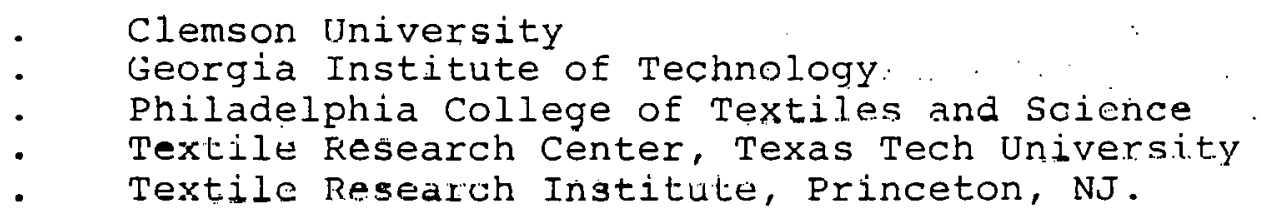

5. Conversations with various private manufacturers and dealers in textile machinery.

6. Conversations with various private manufacturers of textile mill products. 
7. Harvard Business School, Textile Industry Process Note, 1970.

8. R. Hovan Hocutt, Total Concept of Cotton Dust and Waste Control, Pneumafil Corporation, 1978

9. Stephen J. Hudek and Paul T. Bohnslav, The Textile Industry: A Study of Capital Investment Technology and Other Factors Affecting Prescribed Capital Recovery Allowances of Textile Machinery, U.S. Treasury Department, Office of Industrial Economics, February 2, 1976.

10. Donald W. Lyons and John O. Hatcher, Summary of Cotton Textile Manufacturing Processes, Clemson University

11. Herbert R. Mauersberger, Matthews' Textile Fibers, sixth edition, 1954

12. Gilbert R. Merrill, Alfred R. Macormac, and Herbert R. Mauersberger, American Cotton Handbook, second revised edition, 1949 .

13. Andre Morel, Textile Waste Reclamation.

14. M. David Potter and Bernard P. Corbman, Textiles: Fiber to Fabric, fourth edition, 1967

15. Vaclav, Rohlena; Open-End Spinning, Elsevier, 1975

16. Frederic T. Simon and Edward A. Vaughn, "Overview of Nonwoven Technology," Clemson University Review of Industrial Management and Textile Science.

17. SCS Engineers, Inc., Energy Efficiency Improvement Target in the Textile Mill Products Industry SIC 22, Prepared for the Federal Energy Administration, 1977.

18. Textile Industries, "Durable Nonwovens: Each Market Is Unique," September 1978.

19. Textile Manufacturer, "Automatic System of Taste Evacuation for Cotton Spinning Mills," February 1976 
20. Textile World, "Nonwovens Need Image With Consumers," May 1977 .

21. Werner von Bergen and Herbert R. Mauersberger, American Wool Handbook, second enlarged edition, 1948.

22. G. H. Thorndike, "Electrostatic Separation of Fibers," Wool Industry Research Association, WIRA Report No. 160.

23. Dr. J. H. Buchanan and R. J. Wilson, "Reclamation of 'l'extile Waste," Wool Industry Research Association, WIRA Report No. 130. 


\section{ECONOMIC ANALYSIS OF THE TEXTILE MILL PRODUCTS INDUSTRY}

The U.S. textile mill products industry is a mature industry, having been a leader in the industrial revolution more than 200 years ago. Textile mills were once small, family-owned businesses; and even today the industry is highly competitive, with a large number of small, singleplant firms. However, economic conditions have forced a movement toward larger, more fully integrated textile mill operations.

The industry has experienced a slow rate of technological change, and it has therefore, remained quite labor intensive relative to other manufacturing industries. Faced with rising labor costs and increasing competition from less expensive foreign imports, textile mills have been forced to adopt more automated processes to improve production efficiency and reduce costs. But profits were low in the past, and this has limited the ability of the industry to make the necessary investments to improve its competitive position.

Although the industry is more than 200 years old in the United States, it is still changing. The purpose of. this chapter is to examine the evolving nature, structure, and performance of the textile mill products industry and to assess its ability to finance capital investments over the next decade. DUT IT IS STILI HTFHLY COMPETITIVE

The textile mill products industry is composed of more than 5,000 firms and over 7,000 incividual plants employing 913,800 in 1977. Most are small, weakly capitalized firms, and many are single-plant firms. In fact, in the 1972 Census of Manufactures, 2,700 plants were reported to employ less than 20 workers each. Textile mills are also small relative to other industrial companies. Of the top 500 industrial companies listed in Fortune 500 , the largest textile mill firm ranked only 102 nd on the basis of sales in 1977, down from 98 th in 1976. 
The textile mill products industry began with family-owned operations. One of the largest firms in the industry is still a closely-held family business. In 1975, only 80 firms were openly held; the rest were closed corporations.

As previously noted, the textile mill products industry is highly competitive. In 1977, the largest firm had only a 7 percent market share on the basis of sales. Like other competitive industries, it is characterized by a low level of seller concentration. Table 4-1 shows the share of the domestic market held by the largest four, eight, twenty, and fifty firms. An industry with a market share above 50 for the largest four or above 70 for the largest eight is considered concontrated. INost segments of the textile mill products industry are very unconcentrated.* In fact, yarn mills are one of the least concentrated and, therefore, most competitive segments of the industry. Furthermore, the table shows that between 1967 and $1.97 \%$, the concontration ratios for 10 of the 30 segments of the industry actually declined.

Some restructuring of industry has been taking place, however, due to economic pressures. Vertical and horizontal mergers have been effected as firms try to become more. Fully integrated and thus gain control of costs and improve market positions. Consequently, the sizc and the market share of many individual firms have increascd over Lille. Concentration in industry as a whole, however, remains relatively low.

During the early 1960's, the larger textile mills improved their market share significantly thrnigh acquieition. This posed a threat to the future of small, nonintegrated textile mills, and the Federal Trade Commisaion (FTC) took action against a major textile mill in 1968. The firm finally agreed to a consent order stating that no further mergers or acquisitions would be made for 10 years cxrept wilh prior l'TC approval. The FTC subsequently issued merger guidelines for tha lextile industry. The key elements of the FTC policy statement are quoted in Table 4-3.

* The major customer of the textile mill products industrythe apparel industry-is also unconcentrated (See Table 4-2). 
TABLE $4-1$

Market Shares in the Textile Mill Products Industry (SIC 22)

\begin{tabular}{|c|c|c|c|c|c|c|}
\hline INDUSTRY SEGMENT & YEAR & FIRMS & $\begin{array}{l}4 \text { LARGEST } \\
\text { FIRMS }\end{array}$ & $\begin{array}{l}8 \text { LARGEST } \\
\text { FIRMS }\end{array}$ & $\begin{array}{l}20 \text { LARGEST } \\
\text { FIRMS }\end{array}$ & $\begin{array}{l}50 \text { LARGEST } \\
\text { FIRMS }\end{array}$ \\
\hline \multirow{2}{*}{ WEAVING MILLS, COTTON } & 1972 & 190 & 31 & 48 & 72 & 93 \\
\hline & 1967 & 218 & 30 & 48 & 68 & 88 \\
\hline \multirow[t]{2}{*}{ WEAVING MILLS, MAN-MADE FIBER \& SILK } & 1972 & 256 & 39 & 54 & 72 & 88 \\
\hline & 1967 & 272 & 46 & 54 & 68 & 86 \\
\hline \multirow[t]{2}{*}{ WEAVING AND FINISHING MILLS, WOOL } & 1972 & 178 & 38 & 49 & 70 & 90 \\
\hline & 1967 & 262 & 55 & 62 & 76 & 88 \\
\hline \multirow[t]{2}{*}{ NARROW FABRIC MILLS } & 1972 & 324 & 20 & 31 & 49 & 71 \\
\hline & 1967 & 345 & 19 & 31 & 48 & 70 \\
\hline \multirow[t]{2}{*}{ WOMEN'S HOSIERY, EXCEPT SOCKS } & 1972 & 256 & 35 & 49 & 69 & 87 \\
\hline & 1967 & 302 & 32 & 44 & 64 & 82 \\
\hline \multirow[t]{2}{*}{ HOSIERY, N.E.C. } & 1972 & 376 & 19 & 29 & 46 & 66 \\
\hline & 1967 & 423 & 25 & 32 & 46 & 65 \\
\hline \multirow[t]{2}{*}{ KNIT OUTERWEȦR MILLS } & 1972 & 882 & 16 & 26 & 44 & 59 \\
\hline & 1967 & 1156 & 15 & 22 . & 33 & 47 \\
\hline \multirow[t]{2}{*}{ KNIT UNDERWEAR MILLS } & 1972 & 74 & 46 & 61 & 85 & 98 \\
\hline & 1967 & 99 & 36 & 54 & 77 & 95 \\
\hline CIACULAR KNIT FABRIC MILLS & 1972 & 630 & 23 & 31 & 49 & 69 \\
\hline WARP KNIT FABRIC MILLS & 1972 & 174 & 27 & 46 & 72 & 91 \\
\hline \multirow[t]{2}{*}{ KNITTING MILLS, N.E.C. } & 1972 & 72 & 52 & 67 & 83 & 98 \\
\hline & 1967 & 61 & 54 & 71 & 89 & 99 \\
\hline \multirow[t]{2}{*}{ FINISHING PLANTS, COTTON } & 1972 & 182 & 27 & 41 & 67 & 89 \\
\hline & 1967 & 202 & 42 & 59 & 64 & 87 \\
\hline \multirow[t]{2}{*}{ FINISHING PLANTS MAN-MADE FIBER \& SILK } & 1972 & 219 & 56 & 64 & 77 & 89 \\
\hline & 1967 & 212 & 37 & 49 & 63 & 81 \\
\hline \multirow[t]{2}{*}{ FINISHING PLANTS, N.E.C. } & 1972 & 189 & 24 & 36 & 58 & 86 \\
\hline & 1967 & 187 & 29 & 44 & 64 & 86 \\
\hline \multirow[t]{2}{*}{ WOVEN CARPETS AND RUGS } & 1972 & 84 & 78 & 91 & 98 & $99+$ \\
\hline & 1967 & 55 & 76 & 93 & 99 & $99 \div$ \\
\hline
\end{tabular}


TABLE 4-1

Concluded

\begin{tabular}{|c|c|c|c|c|c|c|}
\hline \multirow[b]{2}{*}{ INDUSTRY SEGMENT } & \multirow[b]{2}{*}{ YEAR } & \multirow[b]{2}{*}{ FIRMS } & \multicolumn{4}{|c|}{ MARKET SHARE } \\
\hline & & & $\begin{array}{l}4 \text { LARGEST } \\
\text { FIRMS }\end{array}$ & $\begin{array}{l}8 \text { LARGEST } \\
\text { FIRMS }\end{array}$ & $\begin{array}{l}20 \text { LARGEST } \\
\text { FIRMS }\end{array}$ & $\begin{array}{c}50 \text { LARGEST } \\
\text { FIRMS }\end{array}$ \\
\hline \multirow[t]{2}{*}{ TUFTED CARPETS ANO RUGS } & 1972 & 333 & 20 & 33 & 56 & 78 \\
\hline & 1967 & 210 & 26 & 41 & 67 & 87 \\
\hline \multirow[t]{2}{*}{ CARPETS AND RUGS, N.E.C. } & 1972 & 80 & 78 & 88 & y4 & 99 \\
\hline & 1967 & 78 & 78 & 84 & 93 & 99 \\
\hline \multirow{2}{*}{ YARN MILLS, EXCEPT WOOL } & 1972 & 263 & 21 & 31 & jo & 74 \\
\hline & 1467 & 956 & 21 & 31 & 51 & 73 \\
\hline \multirow[t]{2}{*}{ IHROWING AND WINOING MILLS } & 1972 & 177 & 35 & 51 & 74 & 92 \\
\hline & 1967 & 159 & 50 & 62 & 79 & 93 \\
\hline \multirow{2}{*}{ WOOL YARN MILLS } & 1972 & 91 & 45 & 59 & 83 & 97 \\
\hline & 1067 & 127 & 26 & 42 & 68. & 91 \\
\hline \multirow{2}{*}{ THREAD MILLS } & 1977 & 61 & 62 & II & 92 & $99+$ \\
\hline & 1967 & 63 & 62 & 81 & 95 & $99+$ \\
\hline \multirow[t]{2}{*}{ FELT GOODS, EXCEPT WOVEN FELTS \& HATS } & 1972 & 38 & 51 & 75 & 96 & 100 \\
\hline & 1967 & 33 & 61 & 80 & 98 & 100 \\
\hline \multirow[t]{2}{*}{ LACE GOOOS } & 1972 & 99 & 34 & 51 & 75 & 94 \\
\hline & 1967 & 134 & 31 & 52 & 74 & 92 \\
\hline \multirow[t]{2}{*}{ PADDINGS ANO UPHULSTERY FILLING } & 1972 & 119 & 28 & 10 & 62 & 87 \\
\hline & 1967 & 133 & 34 & 50 & 69 & 88 \\
\hline \multirow[t]{2}{*}{ PROCESSED TEXTILE WASTE } & 1972 & 102 & 54 & 68 & 86 & 97 \\
\hline & 1907 & 132 & 36 & 50 & 70 & 88 \\
\hline \multirow[t]{2}{*}{ COATEU FÁĔHILS, NOT R̃UBBERIZED } & 1972 & 185 & 36 & 32 & 13 & 88 \\
\hline & 1967 & 157 & 31 & 48 & 10 & 88 \\
\hline \multirow[t]{2}{*}{ TIRE CORD ANO FARRIS. } & $\mid y / 2$ & 9 & 84 & 98 & & \\
\hline & 1967 & 12 & 83 & 96 & 100 & \\
\hline NONWOVEN FABRICS & 1972 & hy & 43 & 62 & 81 & 99 \\
\hline \multirow[t]{2}{*}{ LUIIDAGË AND TWINE } & 1972 & $134^{\circ}$ & 36 & 56 & 76 & 31 \\
\hline & 1967 & 147 & 34 & 52 & 77 & 94 \\
\hline TEXTILE GOODS, N.E.C. & 1972 & 338 & 25 & 36 & 54 & 72 \\
\hline
\end{tabular}


TABLE 4-2

Market Shares for the Apparel Industry

\begin{tabular}{|c|c|c|c|c|}
\hline INOUSTRY SEGMENT & $\stackrel{4}{4}$ LARGEST & $\begin{array}{c}8 \\
\text { LARGEST }\end{array}$ & $\begin{array}{c}20 \\
\text { LARGEST }\end{array}$ & $\begin{array}{c}50 \\
\text { LARGEST }\end{array}$ \\
\hline MEN'S AND BOYS' SUITS AND COATS & 19 & 31 & 48 & 65 \\
\hline MEN'S AND BOYS' ORESS SHIRTS AND NIGHTWEAR & 22 & 31 & 50 & 69 \\
\hline MEN'S ANO BOYS' UNDERWEAR & 49 & 71 & 91 & $99+$ \\
\hline MEN'S ANO BOYS' SEPARATE TROUSERS & 29 & 41 & 60 & 76 \\
\hline MEN'S AND BOYS' WO RK CLOTHING & 38 & 53 & 70 & 84 \\
\hline MEN'S ANO BOYS' CLOTHING, N.E.C. & 20 & 27 & 41 & 63 \\
\hline WOMEN'S AND MISSES' BLOUSES \& WAISTS & 18 & 26 & 38 & 55 \\
\hline WOMEN'S ANO MISSES' DRESSES & 9 & 13 & 18 & 28 \\
\hline WOMEN'S ANO MISSES' SUITS \& COATS & 13 & 18 & 26 & 40 \\
\hline WOMEN'S ANO MISSES' OUTERWEAR, N.E.C. & 18 & 25 & 37 & 52 \\
\hline WOMEN'S ANO CHILOREN'S UNOERWEAR & 15 & 23 & 41 & 63 \\
\hline BRASSIERES AND ALLIED GARMENTS & 31 & 45 & 67 & 86 \\
\hline MILLINERY & 17 & 26 & 44 & 68 \\
\hline HATS \& CAPS, EXCEPT MILLINERY & 26 & 39 & 57 & 77 \\
\hline CHILOREN'S DRESSES AND BLOUSES & 17 & 26 & 42 & 63 \\
\hline CHILOREN'S COATS ANO SUITS & 18 & 31 & 55 & 83 \\
\hline CHILOREN'S OUTERWEAR, N.E.C. & 22 & 32 & 48 & 59 \\
\hline FUR GOOOS & 7 & 12 & 23 & 39 \\
\hline FABRIC ORESS ANO WOAK GLOVES & 41 & 59 & 80 & 95 \\
\hline ROBES ANO DRESSING GOWNS & 24 & 39 & 59 & 83 \\
\hline WATERPROOF OUTERGARMENTS & 31 & 40 & 56 & 79 \\
\hline LEATHER AND SHEEP LINED CLOTHING & 19 & $32^{\circ}$ & 57 & 82 \\
\hline APPAHEL BELTS & 21 & 32 & 51 & 12 \\
\hline APPAREL AND ACCESSORIES, N.E.C. & 24 & 37 & 57 & 77 \\
\hline CURTAINS ANO DRAPERIES & 35 & 43 & 52 & 64 \\
\hline HOUSEFURNISHINGS, N.E.C. & 23 & 30 & 43 & 60 \\
\hline TEXTILE BAGS & 27 & 43 & 61 & 94 \\
\hline CANVAS AND RELATED PRODUCTS & 23 & 29 & 40 & 55 \\
\hline PLEATING ANO STITCHING & 22 & 31 & 45 & 61 \\
\hline AUTOMOTIVE ANO APPAREL TRIMMINGS & 67 & 74 & 80 & 35 \\
\hline SCHIFFLI MACHINE EMBROIDERIES & 19 & 28 & 42 & 58 \\
\hline FABRICATED TEXTILE PRODUUCTS. N.E.C. & 23 & 34 & 51 & 69 \\
\hline
\end{tabular}

SOURCE: U.S. DEPARTMENI UF COMMERCE, 1972 CENEUS OF MAMIIFACTURES: 
Merger Guidelines for the Textile Mill Products Industry

THE FOLLOWING ACTIVITIES WERE SEEN AS SUBJECT TO FTC EXAMINATION:

1. "ANY MERGER BETWEEN TEXTILE MILL PRODUCT FIRMS WHERE THE COMBINED SALES OR ASSETS OF THE FIMMS EXCEED \$30O MILLIUN AND THE SALES OR ASSETS OF THE SMALLER FIRM IN THE MFRGER EXCEED \$1O MILLION.

2 ANY HORIZONTAL MERGER IN A TEXTILE MILL PRODUCT SUBMARKET WHERE (A) THE COMBINED FIRMS RANK AMONG THE TOP FOUR OR (B) HAVE A COMBINED MARKET SHARE OF 5 PERCENT UK MORE OF ANY SUBMARKET IN WHICH THE FOUR LARGEST FIRMS ACCOUNT FOR 35 PERCENT OR MORE OF THE MARKET.

3 ANY VERTICAL MERGER, EITHER "BACKWARD" INTO THE SUPPLYING MARKET OR "FORWARD" INTO A PURCHASING MARKET, WHERE A PARTICULAR ACOUISITION OR SERIES OF ACQUISITIONS MAY INVOLVE MARKET SHARES OF 10 PERCENT OR MORE OF THE RELEVANT MARKET OR WHERE THE ACQUISITION OR SERIES OF ACQUISITONS MAY TEND SIGNIFICANTLY TO RAISE BARRIERS TO ENTRY IN EITHER MARKET OR TO DISADVANTAGE EXISTING NON-INTEG RATED OR PARTIALLY INTEG RATED FIRMS IN EITHER MARKET BY OENYING THEM FAIR ACCESS TO SOURCES OF SUPPLY OR MARKETS.

4. ANY ACQUISITION OF A TEXTILE MILL PRO DUCT FIRM WITH SALES OR ASSETS OF $\$ 100$ MILLION OR MORE ANO RANKINF AMONG THE FOUN LARQEST PRODULELSS OF A TEXTILE MILL PRODUCT BY A NON-TEXTILE MILL PRODUCT FIRM WITH SALES OR ASSETS IN EXCESS OF \$250 MII I.ION AND WITH A SUDSTANTIAL MARKE T POSITION IN ANOTHER INDUSTRY. A SUBSTANTIAL MARKET POSITION IS DEFINED AS BEING ONE OF THE TOP FOUR ELLLER3 OF A PRŨUUL'I OR SERVICE IN WHICH THE FOUR LARGEST COMPANIES ACCOUNT FOR 40 PERCENT OR MORE OF THE MARKET." 1

SUURCE: FÉDERAL TRANE COMMISSION, ENTDRCEMENT POLICY WITH RESPECT TO MERGERS IN THE TEXTILE MILL PROOUCTS INDUSTRY, NOVEMBER 22. 1968. 
More recently, the 1968 guidelines have been rescinded due to the adoption of the Hart-Scott-Rodino amendment to Section 7 of the Clayton Act. Basically, the amendment states that the following mergers or acquisitions will be subject to FTC examination:

- If a firm with $\$ 100$ million or more in
sales or assets merges with a firm with
$\$ 10$ million or more in sales or assets
- If the purchase price of an acquisition
is $\$ 15$ milion or more; or if the
acquisition amounts to 15 percent of the
voting securities or assets of the company.

The amendment has the effect of making more mergers and acquisitions subject to FTC scrutiny, e.g., the size of the larger firm in the merger was reduced from $\$ 300$ to $\$ 100$ million.

The nature of the textile mill products industry contributes to the competitive market structure. The industry produces greige and finished fabric (intermediate goods which are made into finished products by the apparel, home finish-. ings, or other industries). In addition, some final consumer items are produced within the industry, generally items requiring very little additional processing after fabrication. Some of these items are as follows:

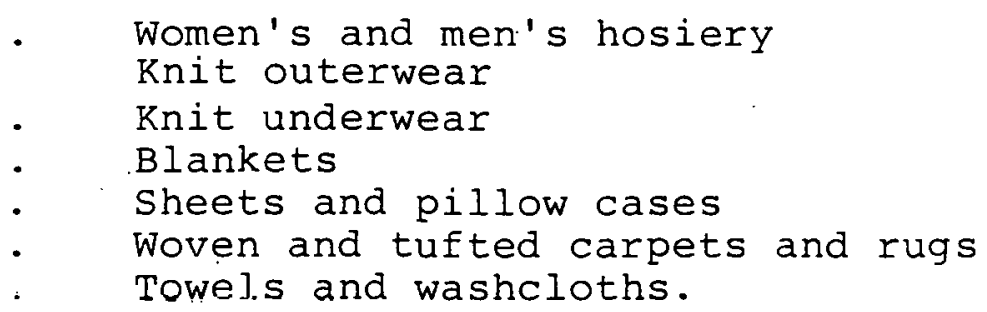

The degree of product differentiation varies between intermediate and final goods. Greige broadwoven goods, for example, tend to be homogeneous. They usually have standard widths, thread counts, and weights. Consequently, cotton and man-made greige goods are essentially commodity fabrics. Even $65 / 35$ polyester/cotton blends have become commodity fabrics. Market prices for cotton, man-llades, and blends are quoted daily-not unlike agricultural commodities, including cotton and wool. For homogeneous products like greige goods, product differentiation and the corresponding barrier to competition is quite low. 
Finished fabric is less homogeneous. Finishes with special characteristics are often indentified by brand name. The man-made fiber producers have also contributed to fabric differentiation by developing and marketing a wide variety of fibers with special and often unique characteristics, the fibers usually being identified by brand name. Final products too are often characterized by a higher degree of product differentiation. Fór example, there is some brand identification for knit underwear, towels, sheets, and carpets.

For the industry as a whole, product differentiation is fairly low. Because the industry is so competitive, near or perfect substitutes for homogeneous and even branded products are plentiful. Consequently, textile mill producers must remain price competitive. Continued restructuring of the textile mill products industry is expected over the next 10 years. The Hart-Scott-Rodino amendment, however, should be an even more effective constraint on merger and acquisition activity than the 1968 guidelines. In addition, the low level of product differentiation and the comparatively small size of textile mill operations should keep the industry competitive through 1987.

4.2

THE DEMAND FOR TEXTILE MILL PRODUCTS HAS GROWN SLOWLY AND CAN FLUCTUATE SIGNIFICANTLY FOR A FIRM OR FOR THE INDUSTRY

The textile mill products industry is a ligh vniume, slow growth business. When lemand slackens, production falls rdpidly because accumulating inventuries is risky. * Consequently, total fiber consumption falls when the demann for textile mill prnductc falls. In 1y/8, total fiber consumption by U.S. textile mills was more than 12.5 billion

* Inventories are risky in the textile mill products industry, even through they can serve as a hedge against increasing labor and materidl costs. The demand for textile mill products is fal top volatili and lincertain to permit the accumulation of inventories during periods of slack demand. In many industries where demand is seasonal or otherwise unevenly distributed throughout the year, operating efficiency is achieved by maintaining fairly consistent production levels during the year even when lemand is low, and selling out of inventory when demand picks up. However, in the tcxtile mill products industry, production rises and falls with demand to avoid inventory risk except for the most staple items, where demand is more predictable. 
pounds, yet the growth of fiber consumption has averaged only 3 percent annually over the past 10 years.

The growth in demand for man-made fibers has been far more dramatic. Total fiber consumption includes cotton, wool, and man-made fibers. Between 1969 and 1978, cotton consumption declined 23 percent and wool consumption fell 63 percent, but man-made fiber consumption increased more than 69 percent. Consequently, in 1978 total U.S. mill consumption by fiber was distributed as follows:

- Cotton
- Man-made fiber
- Wool

The consumption of fibers by U.S. textile mills since 1962 is shown in Table 4-4.

Most of the estimates for total fiber consumption growth through the next decade and beyond range between 2 and 3 percent per year. If the 3 percent historic growth rate continues, total fiber consumption by U.S. textile mills could reach 16.4 billion pounas by 1987. With a 2 percent growth rate, consumption would be 15 billion pounds.

Although cotton and wool consumption have fallen steadily since the early 1960's, the decline appears to be slowing and even stablizing at current levels. Since the total growth of fiber consumption has been only 3 percent annualiy, the continued growth of man-made fibers at the historic rate of 7.7 percent appears unlikely. Given the projected stabilization of cotton and wool consumption, man-made fiber consumption is projected to grow at 3 percert annually. At that rate, man-made fiber consumption by 1987 will be 12.2 billion pounds. If cotton consumption remains at 3.1 billion pounds/year, and wool at $120 \mathrm{million}$ pounds/ year, the distribution of fibers in 1987 will be as follows:

$\begin{array}{ll}\text { - Cotton } & 20.1 \text { percent } \\ \text { - Man-made fiber } & 79.1 \text { percent } \\ \text { Wool } & 0.7 \text { percent }\end{array}$

The demand for textile mill products is gyclical and tends to follow the trend of the general economy. Fiber consumption, for example, peaked at over 12.4 billion pounds in 1973. During the 1974-75 recession, consumption fell sharply-nearly 2 billion pounds-, and not until 1978 did it reach the level previously achieved in 1973. Textile 
TABLE 4-4

Total Fiber Consumption By

U.S. Textile Mills

(Millions of Pounds)

\begin{tabular}{|c|c|c|c|c|}
\hline PERIOD & $\begin{array}{l}\text { TOTAL MILL } \\
\text { CONSUMPTION }\end{array}$ & COTTON & MAN-MADE FIBER & WOOL \\
\hline$: 962$ & $7,070.9$ & $4,229.8$ & $2,412.8$ & 428.3 \\
\hline 1963 & $7,267.2$ & $4,080.6$ & $2,775.0$ & 411.6 \\
\hline 1964 & $7,805.7$ & $4,286.9$ & $3,162.2$ & $35 \overline{6} .6$ \\
\hline 1965 & $8, \overline{5} 23.3$ & $4,522.2$ & $3,614.1$ & 387.1 \\
\hline 1966 & $9,037.1$ & $4,676.8$ & $3,990.1$ & 370.2 \\
\hline 1967 & $y, 0280$ & $4,470.2$ & $4,245.3$ & 312.5 \\
\hline 1968 & $9,823.1$ & $4,188.0$ & $5,305.5$ & 329.6 \\
\hline 1969 & $9,837.3$ & 3,9724 & $5,552.1$ & 312.8 \\
\hline 1970 & $9,595.0$ & $3,853.8$ & $5,500.9$ & 240.3 \\
\hline 1971 & $10,706.5$ & $3,985.8$ & 6.529 .2 & 191.5 \\
\hline 1972 & 11.848 .3 & $3,861.0$ & $7,565.7$ & 218.6 \\
\hline 1973 & $12,473.1$ & $3,657.6$ & $8,664.2$ & 151.3 \\
\hline 1974 & $11,100.5$ & $3,309.0$ & $7,698 \cap$ & 93.5 \\
\hline 1.975 & $10,553.3$ & $3,026.1$ & $7,416.6$ & 110.0 \\
\hline 1976 & $11,588.6$ & $3,413.9$ & $\quad 8,053.0$ & 121.7 \\
\hline 1977 & $12,190.9$ & $3,182.6$ & $8,900.2$ & 108.1 \\
\hline 1978 & $12,557.9$ & $3,049.4$ & $9,391.4$ & 117.1 \\
\hline
\end{tabular}

SOURCE: U.S. DEPARTMENT OF AGRICULTURE, COMMODITY ECONOMICS DIVISION. ECONOMIC RESEARCH SERVICE.

NOTE: GROUP TOTALS MAY NOT ADD TO GRANO TOTAL DUE TO ROUNDING. 
mill activity generally responds rapidly to economic downturns but much more slowly to economic upswings.

Since most textile mill items are intermediate products, their demand should be examined on an end-use basis. There are three major end-use categories for textile mill productsapparel, home furnishings, and industrial and consumer products. Demand in each category is closely tied to the level of consumer income and other factors. The demand for apparel, for example, is influenced by the following:

- Size and growth of the population
Demographic characteristics of the population
Level of consumer income.

Home furnishings demand depends on the following:

- New family formations
- $\quad$ Lhanges in residences
Level of consumer income.

The demand for apparel has slowed just as population growth has slowed in the United States. Both apparel and home furnishings are products consumers tend to postpone buying during recessions, and demand tends to rebound much more slowly than it declined. Every new home sold leads to about four additional household moves, which stimulates the demand for home furnishings. However, new housing starts are quite sensitive to general economic activity. Table 4-5 gives a substantial decline in housing starts during the 1974-75 recession.

Finally, industrial markets for textile mill products also tend to follow the business cycle. As employment and industrial production decline, the demand for industrial textiles also deslines.

The cyclical nature of demand is a macroeconomic effect. The demand for textile mill products is further influenced on a microeconomic level. Consumer tastes, preferences, and spending patterns are major influences on consumption. Consumer demand consists of a base, staple. demand and a fashion demand. The former includes products bought fairly consistently from year to year; the latter is far more erratic. Shifts in consumer preferences in the short run can lead to excess production capacity for certain products and insufficient production capacity for others. 
TABLE 4-5

New Housing Units Started

1960 to 1977

(Thousands)

\begin{tabular}{|ccc|}
\hline YEAR & TOTAL & \% CHANGE \\
\hline 1960 & 1296 & -16.6 \\
1961 & 1365 & 5.3 \\
1962 & 1492 & 9.3 \\
1963 & 1635 & 9.6 \\
1964 & 1561 & -4.5 \\
1965 & 1510 & -3.3 \\
1966 & 1196 & -20.8 \\
1967 & 1322 & 10.5 \\
1968 & 1545 & 16.9 \\
1969 & 1500 & -2.9 \\
1970 & 1469 & -2.1 \\
1971 & 2085 & 41.9 \\
1972 & 2379 & 14.1 \\
1973 & 2057 & -13.5 \\
1974 & 1352 & -34.3 \\
1975 & 1171 & -13.4 \\
1976 & 1548 & 32.2 \\
1977 & 1990 & 28.6 \\
\hline
\end{tabular}

SOURCE: U.S. DEPARTMENT OF COIVIVERCE, STATISTICAL ABSTRACT OF THE UNITED STATES TABLENO. 1366. 
Since 1967 the prices of textile mill and apparel products have increased much more slowly than have the prices for other industrial commodities. Table 4-6 compares the following wholesale price indexes:

Total textile products and apparel Appare1 Textile home furnishings Broadwoven goods Industrial commodities.

Apparel prices have increased more moderately than have the prices for other textile products. All textile and apparel prices have increased more slowly than have other industrial commodity prices. The intense competition in the textile and apparel industries and the increasing competition from foreign imports are partly responsible for these relatively low rates of price increase.

4.3

PRODUCTION COSTS FOR TEXTILE MILL PRODUCTS ARE HIGH AYJD HAVE BEEN INCREASING.

The textile mill products industry is highly labor and material intensive. Production costs represent a substantial portion of product value. In 1976, for example, salaries and wages were 20.2 percent of the value of shipments and material costs were 61 percent. Consequently, inflationary pressures can seriously influence the operations of textile mills. There are four major cost components in industrial production processes that must be examined for the textile mill products industry-labor, materials, energy, and capital.

\subsubsection{The Labor Cost Component}

The textile mill products industry is one of the largest employers in the United States. Further, of the 913,800 textile workers in 1977, more than 80 percent are classified as unskilled or semi-skilled, compared to 60 percent for all manufacturing. In October 1978, average hourly earnings for textile workers were $\$ 4.42$, compared to $\$ 6.33$ for all manufacturing; the textile workers thus earned 69.8 percent of the average manufacturing wage. 'While textile workers' earnings have increased 88.9 percent since 1969 , earnings in all manufacturing rose 98.4 percent. The southward movement of employment in the industry over the past three decades is partially responsible for the relative decline in textile 
TABLE $\quad 4-6$

Wholesale Price Indexes: Textile Mills, Apparel, and Industrial products

(1967-1977)

\begin{tabular}{|cccccc|}
\hline YOTAL TEXTILE & $\begin{array}{c}\text { TOR } \\
\text { PRODUCTS AND } \\
\text { APPAREL }\end{array}$ & APPAREL & $\begin{array}{c}\text { TEXTILE } \\
\text { HOUSE- } \\
\text { FURNISHINGS }\end{array}$ & $\begin{array}{c}\text { BROADWOVEN } \\
\text { GOODS }\end{array}$ & $\begin{array}{c}\text { INDUSTRIAL } \\
\text { COMMODITIES }\end{array}$ \\
\hline 1967 & 100.0 & 100.0 & - & 100.3 & 100.0 \\
1968 & 103.7 & 103.6 & - & 103.5 & 102.5 \\
1969 & 106.0 & 107.4 & - & 103.9 & 106.0 \\
1970 & 107.1 & 110.8 & - & 106.1 & 110.0 \\
1971 & 109.0 & 113.6 & - & 110.9 & 114.1 \\
1972 & 113.6 & 114.8 & 109.2 & 122.3 & 117.9 \\
1973 & 123.8 & 119.0 & 113.3 & 144.3 & 125.9 \\
1974 & 139.1 & 129.5 & 143.1 & 177.8 & 153.8 \\
1975 & 137.9 & 133.4 & 151.9 & 175.4 & 171.5 \\
1976 & 148.2 & 139.9 & 159.3 & - & 182.4 \\
1977 & 154.0 & 147.3 & 171.3 & - & 195.1 \\
\hline
\end{tabular}

SOURCE: DEPARTMENT OF LABOR. 
worker earnings. As wages increased in the Jorth, textile mills moved South where wages traditionally have been lower. Table 4-7 shows the changing geographical distribution of textile mills.

Employment has declined in the textile mill products industry from over 1 million in 1969 to 914,000 in 1977 . Foreign competition and the decline in demand for labor in textile mills have been contributing factors. The Trade Adjustment Assistance Act states that workers who can show their jobs were lost due to import competition are eligible for assistance, and between April 1975 and March 1978, 6,600 workers in the textile mill products industry were recipients of these benefits. By comparison, 45,916 workers in the apparel industry received assistance during that period, indicating a far greater foreign trade impact in the apparel industry.

While employment declined 6.7 percent from 1972 to 1976, salaries and wages measured as a percentage of the value of shipments declined proportionally (at 6.5 percent). As foreign imports have gained an increasing market share, textile mills have adopted less labor intensive practices, thereby reducing the demand for labor. However, the substitution of capital for labor has been insufficient to compensate for increasing import penetration.

Increased unionization and the recent influx of high wage industries into the South have provided additional upward pressure on textile mill wages. If this trend continues without a continued shift toward less labor intensive practices, salaries and wages could begin to take an increasing share of the value of textile shipments.

\subsubsection{The Material cost Component}

The cost of materials (including energy) was 61 percent of the value of textile mill products industry shipments in 1976. Fibers represent a substantial portion of these material costs. The total consumption of fibers by U.S. textile mills in 1978 was more than 12.5 billion pounds, including cotton, wool, and man-made fibers. Cotton accounted for 24.3 percent, while wool contributed less than 1 percent. Man-made fibers amounted to 9.4 billion pounds, 74.8 percent of total consumptiun. The two major natural fibers-cotton and wool-are agricultural commodities, so their prices tend to fluctuate. Cotton and wool prices depend on the following factors: 
TABLE 4-7

Geographic Distribution of Textile Mill Employment (1950-1970)

\begin{tabular}{|ccccc|}
\hline & PMPLOYMENT & $\begin{array}{c}\text { PERCENT OF } \\
\text { INDUSTRY } \\
\text { EMPLOYMENT }\end{array}$ & EMPLOYMENT & $\begin{array}{c}\text { PERCENT OF } \\
\text { INDUSTRY } \\
\text { EMPLOYMENT }\end{array}$ \\
\hline NORTH & 506,000 & 40.5 & 211,000 & 21.7 \\
SOUTH & 603,000 & 48.2 & 669,000 & 68.8 \\
\hline
\end{tabular}

SOURC.E: U.S. DEPARTMENT OF LABOR, BUREAU OF LABOR STATISTICS, EMPLOYMENT AND EARNINGS, STATES AND AREAS 1939-1975. 
- Annual crop production

- Carryover stock

- Government support levels

- Cotton and wool imports

- Demand for natural fibers.

Annual cotton production in the United States since 1962 has varied between 7 and 14 million bales. (One bale is approximately equivalent to 480 pounds.) Supply fell to 7.4 million bales in 1967 , rose to 13.7 million bales in 1972, and fell again to 8.3 million bales in 1975 .

Man-made fiber prices are more stable. In fact, although 1.5-denier polyester staple dropped sharply from 98 cents per pound in 1964 to 61 cents per pound in 1968, it remained constant at 61 cents through April of 1975 .

Hool prices also vary significantly from year to year. Nool is a much more expensive fiber than either cotton or polyester. Table 4-3 gives prices for all three fibers for the period 1964 to 1975 .

While cotton prices have risen since 1964, polyester staple prices have fallen. At the same time, polyester has replaced cotton in many end-uses, and cotton-polyester blends have risen in popularity. Blends have increased from 50 percent to 65 percent polyester in commodity fabrics. Increases to 75 percent or more are anticipated.

Price is only one factor leading to the increased use of polyester and other man-made fibers. Textile mills, for example, tend to prefer man-made over natural fibers for a variety of reasons, including the following:

Prices tend to be more stable; a reliable supply at stable, predictable prices makes production and investment decisions less risky.

- More and more man-made fibers with specific properties are being developed to satisfy both the textile mill and the textile mill customer.

Man-made fibers are more uniform, increasing production efficiency and the uniformity of the textile mill fabric or other products.

Man-made fibers yield more yarn per pound than either cotton or wool: therefore, less waste is generated. 
TABLE $4-8$

Prices for Natural and Man-Made Fibers

1964 to 1976

(Dollars per Pound)

\begin{tabular}{|cccc|}
\hline YEAR & COTTON $^{1}$ & POLYESTER $^{2}$ & WOOL $^{3}$ \\
\hline 1964 & 0.296 & 0.98 & 1.397 \\
1965 & 0.280 & 0.85 & 1.249 \\
1966 & 0.206 & 0.80 & 1.349 \\
1967 & 0.254 & 0.66 & 1.215 \\
1968 & 0.220 & 0.61 & 1.207 \\
1969 & 0.209 & 0.61 & 1.221 \\
1970 & 0.219 & 0.61 & 1.024 \\
1971 & 0.281 & 0.61 & 0.664 \\
1972 & $U .272$ & 0.62 & 1.157 \\
1973 & 0.444 & 0.61 & 2.500 \\
1974 & 0.427 & 0.61 & 1.760 \\
1975 & 0.511 & 0.59 & 1.502 \\
1976 & 0.638 & - & - \\
\hline
\end{tabular}

1 AMERICAN UPI.AND (EXCLUDING LINTERS); FARM PHICE

2 1.5 DENIF.R STAPLE; F:O.B. PRODUCING PLANT

3 RAW, CLEAN, BASIS; GRADED TERRITORY FINE

SOURCE: SURVEY OF CURRENT BUSINESS. 
The continued demand for man-made fibers could result in an increased percentage of man-made fibers in blended fabrics. One key to changing blend ratios is consumer taste; without the unqualified assurance of market acceptance, changes in blend ratios or any other changes that affect product quality are slow to materialize. Textile mills are slow to make changes that could affect their market share.

Man-made fiber producers are far less competitive than natural fiber producers. In fact, the federal government has recently begun to investigate possible anticompetitive activities leading to the shared monopolization of the chemical industry (the producers of man-made fibers). Shared monopolies are those industries where the top three to six companies control at least 75 percent of the market. In 1972 the four largest cellulosic fiber producers had a 97 percent market share. Man-made fiber producers are even beginning to move into the textile mill industry through nonwovens. Dupont, a major chemical company, is one of the largest nonwoven fabric producers in the United States.

Most noncellulosic fiber is made from petrochemicals. Approximately 1 percent of U.S. petroleum consumption goes to the production of synthetic fibers. If the price of crude oil rises simnificantly over the next 10 years, the cost of man-made fibers may also increase. Less competitive industries find it much easier to pass along increased costs. This makes it likely that the more competitive textile mill products industry would bear the burden of the shift toward man-made fibers.

If cotton could be processed to give it some of the characteristics of man-made fibers or if it could achieve greater price stability, it could conceivably regain a larger share of the total fiber market. Research and development in man-made fibers has far exceeded that in natural tibers. Dupunt alone spent $\$ 28.5$ million on fiber research in 1973. On the other hand, the funds available to the natural fiber producer industry for $R \& D$ are limited. The Consumer Protection Act of 1973 authorizes the Secretary of Agriculture to make available $\$ 10$ million annually for research. Furthermore, under the cotton Research and Promotion Act of 1966, upland cotton producers are assessed for the funds earmarked for research and promotion. In 1973, upland cotton production was 12.9 billion bales; consequently a total of $\$ 22.9 \mathrm{million}$ from both sources was available for research. This was less than DuPont alone spent during that year. In the future, increased $R \& D$ for natural fibers could improve the competitive position 
of both cotton and wool. However, since funds for $R \& D$ are more available to man-made fiber producers, any major shift from current trends seems unlikely. Actually, R\&D spending by the textile mill products industry has lagged behind that for all other manufacturing, as shown in Table 4-9.

\subsubsection{The Energy Cost Component}

Energy consumption and fuel costs for the textile mill products industry are low relative to those same items for other industries. The industry is the tenth ranked energyconsuming industrial sector. Figure 4-1 shows that the steel, aluminum, and paper industries use far more energy as a percent of sales than the textile industry. Energy costs as compiled by the Bureau of the census amount to less than 3 percent of the value of shipments. However, given the continued shift toward man-made fibers--especially petrochemical, non-cellulosic fibers--the energy share of total costs would rise if serious or prolonged energy shortages or rapidly rising energy prices prevail.

In 1972, the U.S. textile industry consumed about 0.4 quads of process enerqy. This is equal to 2 percent of U.S. industrial energy consumption and 0.6 percent of total U.S. energy consumption. IJatural gas and electricity are the principal forms of energy, as shown in the following breakdown of consumption:

$\begin{array}{lr}\text { - Natural gas } & 29 \text { percent } \\ \text { - Electricity } & 24 \text { percent } \\ \text { - Oil } & 19 \text { pelcent } \\ \text { - Coal } & 9 \text { percent } \\ \text { - Other (propane, etc) } 19 \text { percent. }\end{array}$

\subsubsection{Dry Processing}

spiming and weaving of textiles (dry processing) consime about 0.76 ring fer ycar, 11 about 40 percent of the industry's energy. Energy is consumed primarily in the form of electririty for cquipmenl drives, lighting, and environmental conditioning. Other sources of energy are used for space heating.

Energy consumption for environmental conditioning (the control of humidity, temperature, and static electricity) is particularly important to the spinning and weaving processes. Such controls lessen fire and explosion hazards and allow for rapid, uninterrupted movement of thread, yarn, and cloth. 
TABLE $4-y$

$R \& D$ Spending in the Textile Mill

Products Industry vs $R \& D$ spending in $A l l$ Industries (Millions)

\begin{tabular}{|lcc|}
\hline YEAR & TEXTILES & ALL INDUSTRIES \\
\hline 1973 & $\$ 64$ & $\$ 20,900$ \\
1974 & 72 & 23,100 \\
1975 & 70 & 22,573 \\
1976 & 60 & 27,566 \\
$1977 \mathrm{e}$ & 68 & 30,623 \\
$1978 f$ & 74 & 39,707 \\
$\%$ CHANGE & & 90 \\
(73-78) & 16 & \\
\hline
\end{tabular}

$$
\begin{aligned}
& e=\text { ESTIMATE } \\
& f=\text { FORECAST }
\end{aligned}
$$

SOURCES: NATIONAL SCIENCE FOUNDATION

MCGRAW HILL - DEPARTMENT OF ECONOMICS. 
FIGURE 4-1

Tctal Energy Consumption and the Cost of Purchased Fuels

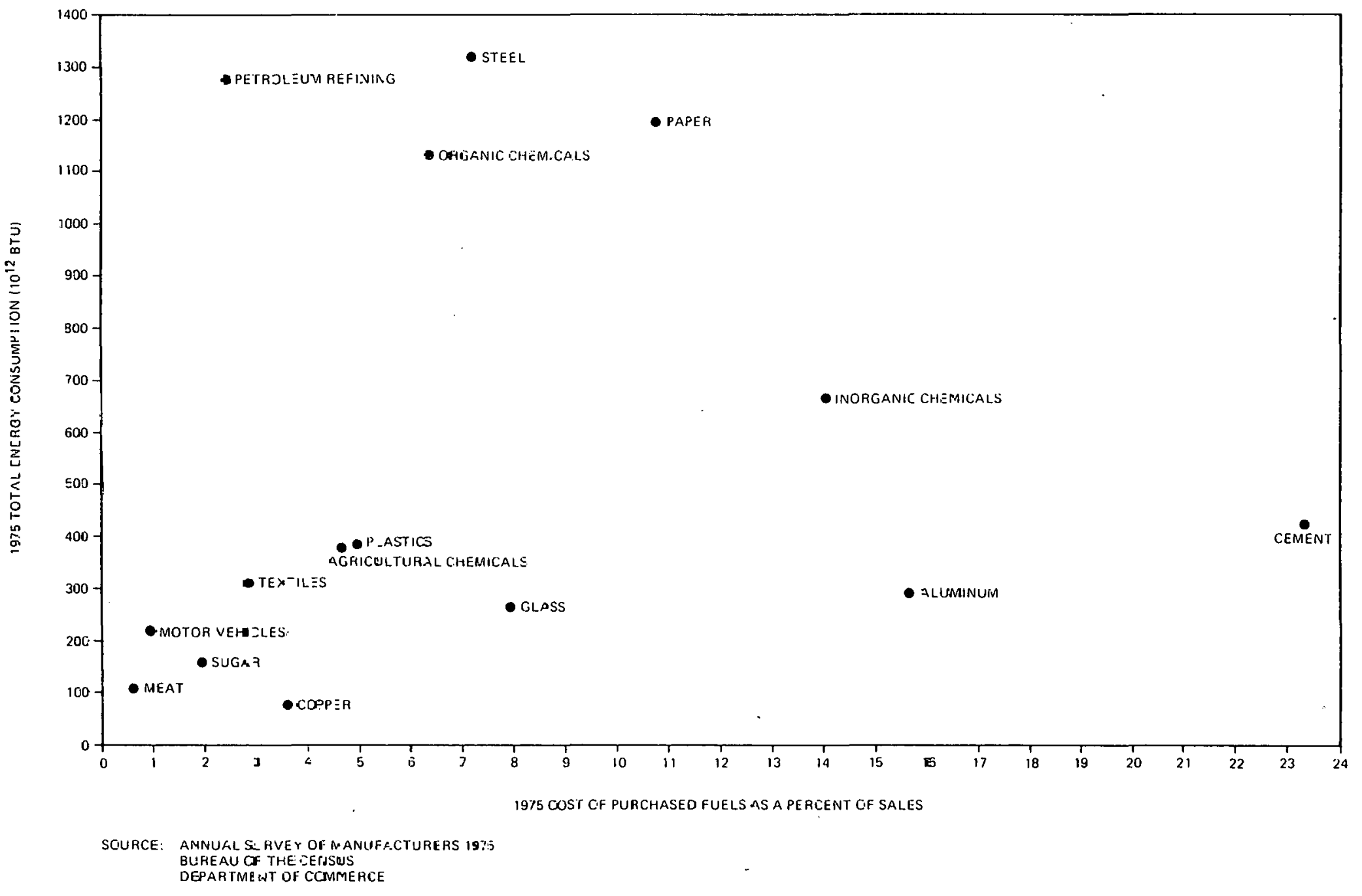




\subsubsection{Wet Processing}

Dyeing and finishing, the processes of converting greige goods into marketable goods (wet processing), account for about 60 percent of the energy consumed in the textile industry. This is about 0.24 quads per year, the energy being supplied as natural gas, oil, and coal for driving steam boilers. Natural gas is also used to fire dyers for heat-setting, finishing, and moisture removal. Energy consumption in the major stages of wet processes is as follows:

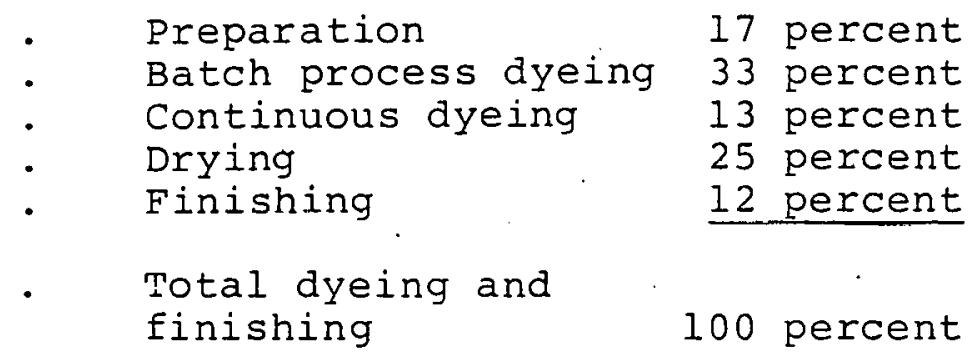

Preparation operations are continuous and are conducted to prepare greige goods for dyeing. Energy is supplied to - preparation stages to heat water and chemicals which remove foreign matter and to develop steam for bleaching. These steps help ensure a consistent dye color throughout the material batch. Preparation operations include four stages: slashing, singeing, mercerization, and drying.

Dyeing is accomplished by several variations of batch and continuous processes. Batch processes include six variations; the six, with the percent of dyeing energy used by each, are as follows:

$\begin{array}{ll}\text { : } & \text { Atmospheric beck } \\ : & \text { Jig } \\ : & \text { Jet } \\ \text { : Package/beam } & \text { Stock }\end{array}$
40 percent
3 percent
4 percent
4 percent
17 percent
4 percent

In addition, there are three variations of the continuous dyeing process in use today:

$\begin{array}{ll}\text { - Fabric dye range } & 13 \text { percent } \\ \text { - Carpet dye range } & 4 \text { percent } \\ \text { Printer } & 11 \text { percent } \\ & \begin{array}{l}\text { Total energy for } \\ \text { dyeing }\end{array}\end{array}$


Approximately one-half of the dyeing is accomplished in a dye beck or kettle. This process is energy inefficient. Approximately 98 percent of the supplied energy is discarded in the dye liquor after the dyeing operation is complete, and the remaining 2 percent is lost by radiation.

Drying and finishing are generally continuous operations. Equipment is typically one of four types: infrared radiation, mechanical (roller process), steam cans, or hot air. Like color dyeing, the drying processes in use today are inefficient when compared with what is theoretically possible.

\subsubsection{The Capital Cost Component}

Capital expenditures in the textile mill products industry have shown a mild upward trend during the past 10 years, in spite of the fact that profit levels are lower than they are in other manufacturing industries. (See Table 4-10 for data on textile mill products industry capital expenditures.) Expenditures on new plants and equipment rose from $\$ 630$ million in 1969 to nearly $\$ 1.1$ billion in 1978, or about 7.5 percent annually. McGraw-Hill estimates that expenditures on new plants and equipment will grow 9.8 percent annually through 1991. At this rate, capital expenditures could reach $\$ 2.4$ billion by 1987 . Much of the growth in capital expenditures over the next ten years will be due to the increasing costs of equipment replacement; the need to improve production efficiency through automation; and the increased demands by government agencies that standards be met regarding cotton dust, noise, etc. The 9.8 percent growth rate seems reasonable in the face of these increasing costs and regulations.

Capital investment in the textile mill products industry has averaged about 2.6 percent of sales annually since 1970 . Some of the larger firms in the industry spend a significantly greater percentage of sales on capital investment. In a recent analysis of seven major textile mill product companies by Merrill Lynch, the larger firms spent between 4 and 6 percent of sales; mostly to improve existing facilities and to increase efficiency, rather than to expand sapacity.

There is a disparity between the growth projection made by the American Textile Manufacturers Institute (ATMI) and that based on Bureau of the Census data. While the ATMI data indicate a growth of 7.5 percent annually for new plant and equipment expenditures, the Census shows a fairly steady $\$ 1$ billion annual expenditure. ATMI data 
TABLE $4-10$

Capital Expenditures in the Textile Mill Products Industry

\begin{tabular}{|c|c|c|c|}
\hline YEAR & $\begin{array}{c}\text { NEW PLANT AND } \\
\text { EQUIPMENT } \\
\text { EXPENDITURES } \\
\text { (MILLIONS) }\end{array}$ & $\begin{array}{c}\text { SALES } \\
\text { (MILLIONS) }\end{array}$ & $\begin{array}{c}\text { CAPITAL EXPENDITURES } \\
\text { AS PERCENT OF SALES }\end{array}$ \\
\hline 1970 & 560 & 21,599 & 2.6 \\
197.1 & 610 & 22,938 & 2.7 \\
1972 & 730 & 25,616 & 2.8 \\
1973 & 770 & 29,113 & 2.6 \\
1974 & 840 & 31,220 & 2.7 \\
1975 & 660 & 28,116 & 2.3 \\
1976 & 810 & 33,932 & 2.4 \\
1977 & 920 & 34,317 & 2.7 \\
\hline
\end{tabular}

* sales are net of returns, allowances, excise and sales taxes

SOURCE: ATMI, FEDERAL TRADE COMMISSION, U.S. DEPARTMENT OF COMMERCE. 
were considered more appropriate for this report, because the census data include textile operations owned by firms whose major activity is outside the textile industry, whereas ATMI data do not. Operations outside SIC 22 are not relevant to this analysis.

According to the 1972 Census of Manufactures, capital expenditures varied from a low of $\$ 16,000$ per plant (for lace goods) to a high of $\$ 536,000$ per plant (for yarn throwing and winding).. As shown in Table 4-11, only six segments of the industry had capital expenditures per plant over $\$ 200,000$.

4.4

INCREASING COMPETITION FROM FOREIGN IMPORTS HAS PROMPTED CHANGES IN THE INDUSTRY

During the 1960's, imports of textile and apparel products nearly tripled. The pace has continued through the 1970's. In 1977, more than $\$ 5.9$ billion worth of textilc and apparel products were imported. Since the rise in exports has been much slower, the textile trade deficit has steadily increased. The last trade surplus was in 1957. In 1977 , the deficit had reached nearly $\$ 3.4$ billion (see Table 4-12).

The import penetration of U.S. markets has seriously threatened the domestic textile mill products industry. Domestic apparel markets have been afferted tho moct. Apparel is the major consumer of textile mill products, consuming 42 percent of all fibers. The increase in imports has shrunk domestic apparel markets for U.S. textile mill products. Table 4-13 illustrates the growth of imports relative to the domestic market. Cotton textile and apparel products showed the greatest penetration since 1967. Kurt salmon Associates, Inc., a New York textile and apparel consulting firm, predicts that, under present trade policies, total imports could increase to 35 percent of the domestis market by 1990.

In 1977, the General Agreement on Tariffs and Trade (GAT'I) Multifiber Arrangement was renewed for 4 years. Under this agreement, a 6 percent quota growth for combined textile and apparel imports is permitted. Since total fiber consumption grows at only 3 percent annually, the textile trade deficit will continue to rise under this arrangement. However, recent agreements between the textile industry and administration reoresentatives may reduce this continuing growth somewhat. 


$$
\text { TABLE 4-11 }
$$

Capital Expenditures Per Plant for Six Industry Segments*

\begin{tabular}{|c|c|}
\hline $\begin{array}{l}\text { TEXTILE MILL } \\
\text { SEGMENT }\end{array}$ & $\begin{array}{c}\text { CAPITAL EXPENDITURE } \\
\text { PER PLANT }\end{array}$ \\
\hline YARN THROWING AND WINDING & $\$ 536,000$ \\
\hline TIRE CORD AND FABRIC & 489,000 \\
\hline CIRCULAR KNIT FABRIC & 337,000 \\
\hline WEAVING MILLS, MAN-MADE & 331,000 \\
\hline WEAVING MILLS, COTTON & 237,000 \\
\hline WARP KNIT FABRIC & 237,000 \\
\hline YARN MILLS, EXCEPT WOOL & 226,000 \\
\hline
\end{tabular}

* THE SEgMENTS INCLUDED IN THIS EXHIBIT HAD CAPITAL EXPENDITURES PER PLANT IN EXCESS OF $\$ 200,000$ IN 1972.

SOURCE: DEPARTMENT OF COMMERCE, 1972 CENSUS OF MANUFACTURERS. 
TABLE 4-12

U.S. Textile Trade

F.A.S. Values

(Millions of Pounds)

\begin{tabular}{|c|c|c|c|}
\hline PERIOD & IMPORTS $^{1}$ & EXPORTS ${ }^{1}$ & $\begin{array}{l}\text { BALANCE OF } \\
\text { TEXTILE TRADE }\end{array}$ \\
\hline 1957 & 549 & 563 & +14 \\
\hline 1958 & 562 & 526 & $-\quad 36$ \\
\hline 1959 & 744 & 547 & 202 \\
\hline 1960 & 066 & 618 & -248 \\
\hline 1961 & 773 & 578 & -195 \\
\hline 1962 & 1,013 & 580 & -433 \\
\hline 1963 & 1,074 & 583 & -491 \\
\hline 1964 & 1,132 & 681 & -451 \\
\hline 1965 & 1,342 & 640 & -702 \\
\hline 1966 & 1,516 & 679 & -837 \\
\hline 1967 & 1,460 & 695 & -765 \\
\hline 1968 & 1,818 & 694 & $-1,124$ \\
\hline 1969 & 2,125 & 753 & $-1,372$ \\
\hline 1970 & 2,402 & 776 & $-1,626$ \\
\hline 1971 & 2,913 & 837 & $-2,076$ \\
\hline 1972 & 3,411 & 993 & $-2,418$ \\
\hline 1973 & 3,722 & 1,497 & $-2,225$ \\
\hline 1974 & 3,952 & 2,165 & $-1,787$ \\
\hline 1975 & 3,780 & 2,027 & 1,753 \\
\hline 1976 & 5,269 & 2.480 & $-2,709$ \\
\hline 1977 & 5,926 & 2,567 & $-3,359$ \\
\hline \multicolumn{4}{|l|}{ 1978: } \\
\hline IST $\cap$ & 1.711 & 803 & $-1,108$ \\
\hline 2ND 0 & 1,968 & 722 & $-1,246$ \\
\hline 3RD D & 2,274 & 711 & $-1,563$ \\
\hline
\end{tabular}

'IMPORT AND EXPORT DATA INCLUDE TEXTILE MANUFACTIIRES, AND CLOTHING (EXCEPT DONATEU FUR CHARITY) OF ALL FIBERS COMPILED ON THE BASIS OF THE STANDARD INTERNATIONAL TRADE CLASSIFICATION (DIVISION 65 FOR TEXTILES AND 84 FOR CLOTHING) OF THE FT.990. ${ }^{2}$ TEXTILE BALANCE OF TRADE REPRESENTS EXPORTS MINUS IMPORTS. MINUS SIGN INDICATES AN EXCESS OF IMPORTS OVER EXPORTS.

SOURCE: ATMI 
TABLE $4-13$

Ratio of U.S. Imports for Consumption

to Apparent Domestic Market for

Textile Mill and Apparel Products*

\begin{tabular}{|c|c|c|c|}
\hline \multirow{2}{*}{ YEAR } & \multicolumn{3}{|c|}{ TEXTILE AND APPAREL PRODUCT RATIO } \\
\cline { 2 - 4 } & COTTON & WOOL & MAN-MADE \\
\hline 1967 & 9.5 & 21.6 & 3.9 \\
1968 & 10.7 & 25.4 & 4.6 \\
1969 & 11.7 & 25.4 & 5.3 \\
1970 & 11.2 & 28.0 & 8.2 \\
1971 & 11.6 & 28.0 & 10.5 \\
1972 & 14.6 & 25.1 & 9.4 \\
1973 & 14.5 & 26.3 & 7.3 \\
1974 & 14.7 & 22.6 & 6.3 \\
1975 & 15.7 & 19.6 & 6.4 \\
1976 & 19.1 & 23.4 & 7.1 \\
\hline
\end{tabular}

*.ApPaRent domestic CONSUMPTION IS DEFINED AS DOMESTIC PRODUCTION PLUS IMPORTS MINUS EXPORTS.

SOURCE: DEPARTMENT OF COMMERCE, U.S. PRODUCTION, IMPORTS, AND IMPURT/PRODUCTION RATIOS FOR COTTON, WOOL, AND MAN-MADE FIBER TEXTILES AND APPAREL, JANUARY 1978. 
Increasing labor costs in the United States and, consequently, an inefficient labor intensity in U.S. textile mills have improved the competitive position of foreign imports. Labor costs are much lower abroad. Although the domestic textile mill products industry is somewhat less labor intensive than its foreign competitors, even greater automation is needed in order to accomplish the following:

- Improve the efficiency of U.S. textile mill production

- Increase the rate of production in U.S. textile mills

- Reduce the unit costs of U.S. textile mill products.

The increasing concentration in the textile mill products industry has been necessary to maintain a competitive position in the face of rising labor costs and shrinking domestic markets. However, textile mill operations have not expanded overseas because of the high capital costs of plant and equipment, even though labor costs are much lower abroad. Apparel operations that are more labor intensive are better suited to "foreign flight." In the textile mill products industry, the movement toward more fully integrated, less labor intensive operations has been the key to maintaining a competitive position.

\subsection{THE TEXTILE MILL PRODUCTS INDUSTRY HAS BEFN BCONOMICALLY LESS SUCCESSFUL THAIJ ONHER IINDUSTRIES}

The value of textile shipments in 1977 was $\$ 40.8$ b11110n. Éstimates for 1978 range between $\$ 43.7$ and $\$ 45$ billion. The value of shipments has grown 10 percent annually from 1969 to 1978. At that rate, textile shipments could top \$1 trilliun by 198\%. However, because of the segmented nature of the textile mill products industry, a substantial part of these figures comes from intra-industry transactions. The value of shipments in the industry in 1976 was $\$ 36.4$ bilition according to the 1976 Annual. Survey of Manufactures. The cost of materials was neariy $\$ 22.2$ billion; value added was only $\$ 14.2$ billion. Consequently, the profit margin for textile mills is quite low.

In a competitive industry like the textile mill products industry, low profits are to be expected. In fact, profits in the industry have been historically lower than the average 
for all manufacturing industries. In 1977, profit per dollar of sales was 2.4 percent. By comparison, all manufacturing industries achieved 5.3 percent. Profit on stockholder's equity was 8.7 percent for the textile mill products industry in 1977 compared to 14.2 percent for all manufacturing (see Figure 4-2). In an industry experiencing rapid growth, competition is less intensive and larger returns are possible. In a slow growth business like the textile industry, competition is keen, and this depresses profit margins. To make matters worse, privately held companies have been willing in the past to accept smaller returns than their openly held competitors. As a result, the industry has remained competitive despite the trend toward larger, more fully integrated operations.

Profits for the industry appear to respond to general economic conditions. In 1975, profits fell to only 1.5 percent; in 1973, prior to the recession, they were at 2.9 percent. Despite the movement toward integration in the industry, a movement that will improve value added and increase profits, industry profits have shown little improvement since 1970. Although profits fluctuate with the economy, their general trend has not been upward.

In a high volume business like the textile mill products industry, profit is sensitive to mill operating rates (or capacity utilization). When mill operating rates are below optimum levels, price competition is keen. Increasing mill operating rates can improve financial performance. But general economic conditions and market demand dictate production levels. When sales decline, mills must produce less. The textile mill products industry is market oriented, and reducing the lead time between production and delivery is essential; yet inventories are risky to the textile mill producer. So the primary adjustment mechanism when demand rises or falls is the rate of production. nperating rates for the past three years are shown in Table 4-I4: As the economy rose out of the 1974-75 recession, capacity utilization rose from 54.7 percent in the first quarter of 1975 to 86.2 percent in the fourth. For the textile mill products industry, then, production is highly responsive to general economic conditions. In fact, production is more responsive in this industry than it. is in all manufacturing industries. The Federal Reserve Board ( $F R B$ ) Index of Industrial Production shows far greater swings for textile mills than for all manufacturing industries (Figure 4-3). 


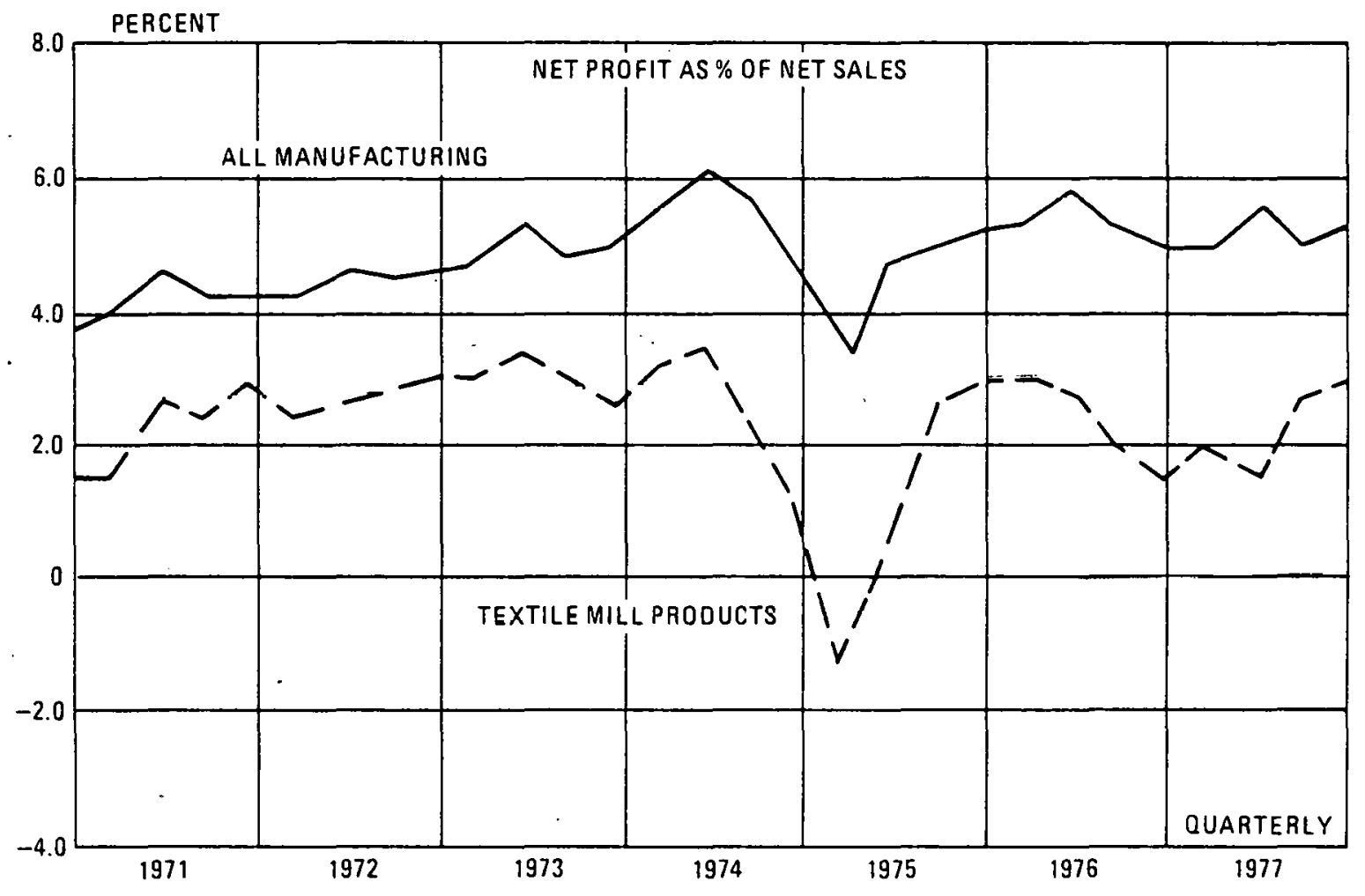

\begin{tabular}{|c|c|c|c|c|c|c|c|c|}
\hline & 1970 & 1971 & 1973 & 197.3 & 1974 & 1975 & $19 / 6$ & 1977 \\
\hline \multicolumn{9}{|l|}{ SALES: ${ }^{1}$} \\
\hline ALL MANUFACTURING INOUSTRIES & 708,810 & 751,061 & 849,523 & 978,594 & $1,060,215$ & $1,065,215$ & 1.203 .233 & $1,328,063$ \\
\hline TEXTILE MILL PRODUCTS & 21,599 & 22,938 & 25.616 & 29,118 & 31,220 & 28,116 & 33,932 & 34.317 \\
\hline \multicolumn{9}{|l|}{ NET PROFITS: ${ }^{2}$} \\
\hline ALL MANUFACTURING INOUSTRIES & 28,572 & 31.038 & 36,467 & 48,134 & 58,747 & 49,135 & 64,519 & 70,366 \\
\hline TEXTILE MILL PROOUCTS & 413 & 558 & 659 & 831 & $78 n$ & 400 & 809 & 828 \\
\hline \multicolumn{9}{|l|}{ PROFIT PER OOLLAR OF SALES: ${ }^{3}$} \\
\hline ALL MANUFACTURING INDUSTRIES & 4.0 & 4.2 & 4.3 & 5.0 & 5,5 & 4.6 & 5.4 & 5.3 \\
\hline TEXTILE MILL PAODUCTS & 1.9 & 2.4 & 2.6 & 2.9 & 2.5 & 1.5 & 2.4 & 2.4 \\
\hline \multicolumn{9}{|l|}{ PRDFIT ON TOTAL AESETS:A } \\
\hline ALL MANUFACTURING INDUSTRIES & 5.1 & 5.2 & 5.5 & 6.7 & 8.0 & 6.2 & 7.5 & 7.6 \\
\hline TEXTILE MILL PRODUCTS & 2.8 & 3.7 & 4.0 & 4.7 & 3.8 & 2.2 & 4.2 & 4.4 \\
\hline \multicolumn{9}{|l|}{ PROFIT ON STOCKHOLDERS' EQUITY: ${ }^{4}$} \\
\hline ALL MANUFACTURING INDUSTRIES & 9.3 & 9.7 & 10.6 & 13.1 & 14.9 & 11.6 & 14.0 & 14,2 \\
\hline TEXTILE MILL PRODUCTS & 5.1 & 6.6 & 7.5 & 9.6 & 8.0 & 4.4 & 8.0 & 8.7 \\
\hline
\end{tabular}

'SALES ARE NET OF RETURNS. ALLOWANCES, EXCISE AND SALES TAXES, IN MILLIONS OF DOLLARS. 2 AFTER FEde RAL AND OTHER INCOME TAXES, IN MILLIONS OF OOLLARS. IPERCENT OR CENTS. "ANNUAL DATA ARE QUARTERLY AVERAGES. OUARTERLY DATA AT ANNUAL RATES. NOTE: PROFIT DATA INCLUDE CERTAIN FOREIGN INCOME. SOURCE: FEDERAL TRADE COMMISSION, ATMI. 
TABLE 4-14

Output, Capacity, and Operating Rates for the Textile Mill Products Industry

\begin{tabular}{|c|c|c|c|c|}
\hline YEAR & QUARTER & OUTPUT & CAPACITY & $\begin{array}{c}\text { PERCENT } \\
\text { UTILIZATION }\end{array}$ \\
\hline \multirow{2}{*}{1975} & 1st & 93.3 & 131.0 & 54.7 \\
& 2nd & 94.9 & 132.9 & 71.4 \\
& 3rd & 110.7 & 133.9 & 82.7 \\
& 4th & 118.2 & 137.2 & 86.2 \\
\hline \multirow{2}{*}{1976} & 1st & 116.5 & 138.2 & 84.2 \\
& 2nd & 115.5 & 139.0 & 83.1 \\
& 3rd & 114.4 & 139.8 & 81.8 \\
& 4th & 111.7 & 140.6 & 79.4 \\
\hline \multirow{2}{*}{1977} & 1st & 111.3 & 141.4 & 78.7 \\
& 2nd & 110.9 & 141.9 & 78.1 \\
& 3rd & 112.3 & 142.5 & 78.8 \\
& 4th & 117.9 & 143.0 & 82.4 \\
\hline
\end{tabular}

SOURCE: STANDARD \& POOR'S INDUSTRY SURVEY: TEXTILES JULY 13. 1978. 
FIGURE $4-3$

Index of Industrial production

$(1967=100)$

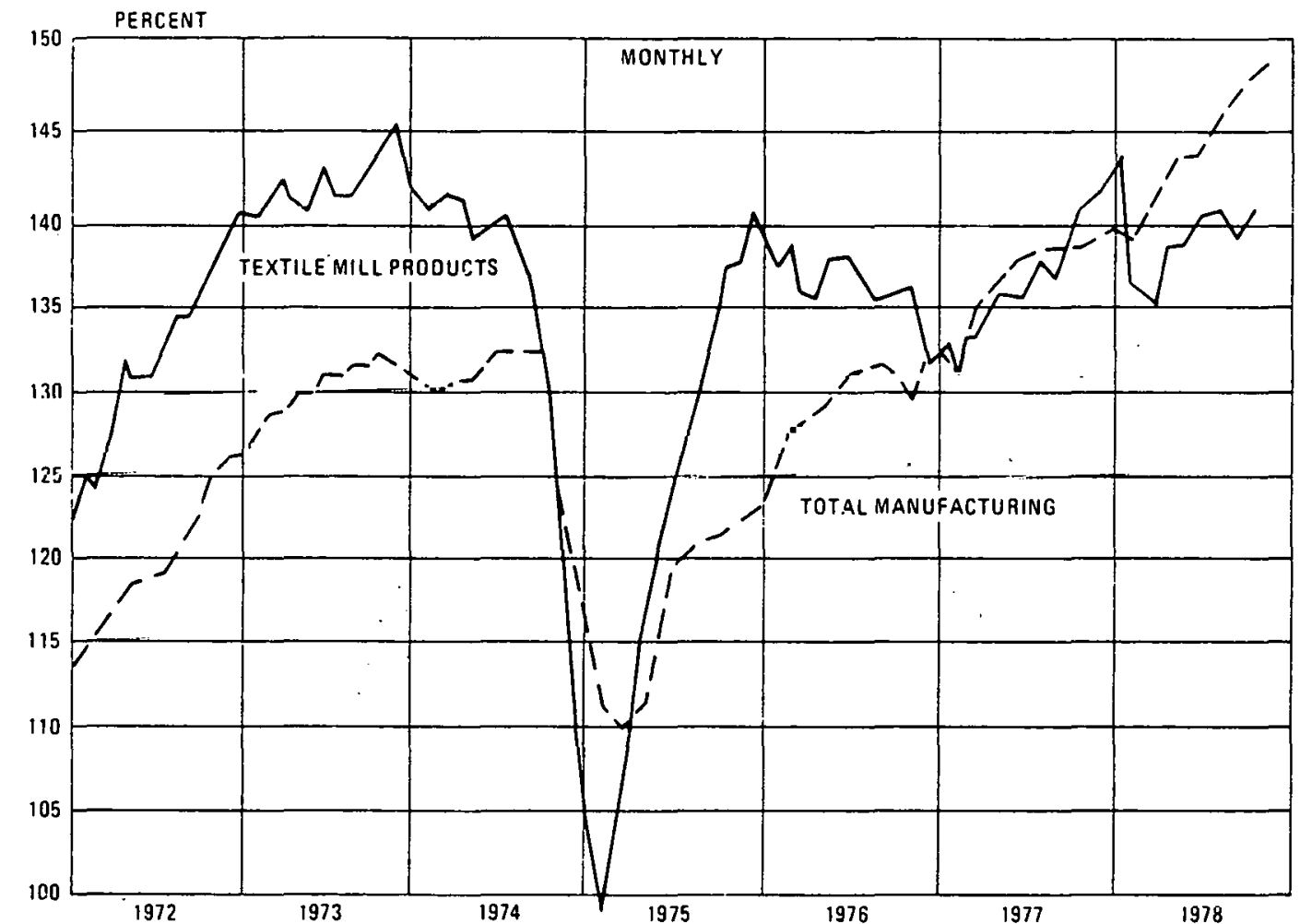

\begin{tabular}{|c|c|c|c|c|c|c|c|c|}
\hline \multirow[b]{2}{*}{ INUUSTRY GROUPING * } & \multicolumn{8}{|c|}{ ANNUAL AVERAGES } \\
\hline & 1971 & 1972 & 1973 & 1974 & 1975 & 1976 & 1977 & 1978 \\
\hline TOTAL INDEX' & 109.6 & 119.7 & 129.8 & 129.3 & 117.8 & 129.8 & 137.1 & 144.0 \\
\hline AI I MANUFACTURING & 108.2 & 118.9 & 129.8 & 129.4 & 116.3 & 129.5 & 137.1 & 144.5 \\
\hline TEXTILE MILL PRODUCTS & 116.5 & 132.7 & 142.9 & 132.8 & 122.3 & 136.4 & 137.1 & 1.368 \\
\hline COTTON FARRIS.S & 00.8 & 08.7 & 83.5 & 76.6 & 70.7 & 80.8 & 16.5 & 73.0 \\
\hline MAN-MADF FABRICS & 110.9 & 1989 & !b.x. & . 168.4 & 141.0 & i'ô. & 163.2 & 168.2 \\
\hline WOOL FABRICS & 47.6 & 43.3 & 56.0 & 44.8 & 44.8 & 54.7 & 49.9 & 57.6 \\
\hline KNIT GOODS & 135.3 & 173.6 & 194.0 & 1835 & 176.0 & 189.0 & 194.3 & 182.3 \\
\hline FABRIC FINISHING & 110.0 & 123.6 & 135.4 & 130.5 & 119.5 & 130.9 & 146.0 & 155.5 \\
\hline CARPETING & 149.1 & 180.5 & 194.3 & 179.9 & 157.7 & 966.4 & 180.5 & 181.9 \\
\hline YARN \& MISC. TEXTILES & 130.0 & 140.2 & 145.4 & 129.1 & 116.8 & 130.5 & 127.0 & 132.5 \\
\hline APPAREL PRODUCTS & 104.7 & 109.4 & 117.3 & 114.3 & 107.6 & 122.2 & 124.2 & 124.2 \\
\hline
\end{tabular}

NOTE: MOST RECENT DATA ARE PRELIMINARY. 'SEASONALLY AOJUSTED MONTHLY OATA.

SOURCE: U.S. FEDERAL RESERVE SYSTEM, ATMI. 
For the industry, demand, production, and profitability are cyclical. For any given textile firm, an additional level of uncertainty can affect performance. In the U.S. textile mill products industry, the typical mill offers a fairly limited product line. Horizontal integration through diversification has improved product mix, but if the major product line suffers from reduced demand, firms do poorly.

The textile mill products corporations listed in the top 1,000 industrials in Fortune for the past 4 years show considerable variability in performance from year to year. The variability is caused in part by changing demand conditions. Furthermore, it is clear that size does not guarantee larger returns. Variability from firm to firm is also large and independent of size. Cyclical and consumer demand fluctuations are a far greater influence than the size of the company. In fact, a small, nonintegrated textile mill can reap huge profits in any given year if it hits on the right product or product mix. The move toward more fully integrated operations does not seem to have had a great effect on performance in the industry as a whole. This is shown in Tables 4-15 and 4-16.

4.6 SIGNIFICANT RETURNS ARE REQUIRED TO. EICOURAGE NEVT IIIVESTMENTS, BECAUSE TEXTILE MILLS OPERATE ON THIN MARGINS

In assessing the ability of the textile mill products industry to finance capital investments, the foregoing analysis centered on the significance of the economic environment in which the industry operates. The following factors were shown to affect economic performance:

- Competitive structure of the industry

- Slow industry growth

- Sensitivity to cycles in general business activity

Sensitivity to variable consumer tastes and preferences

High production costs for textile mill products

Increasing penetration of imports into domestic textile markets. 
TABLE $4-15$

profit on Sales by Company and Year

\begin{tabular}{|c|c|c|c|c|c|c|c|c|}
\hline \multicolumn{4}{|c|}{ INDUSTRIAL CORP. RANK } & \multirow[b]{2}{*}{ TEXTILE COMPANY* } & \multicolumn{4}{|c|}{ NET INCOME AS \% OF SALES } \\
\hline 1974 & 1975 & 1976 & 1977 & & 1974 & 1975 & 1976 & 1977 \\
\hline 80 & 104 & 98 & 102 & BURLINGTON INDUSTRIES & 4.3 & 2.1 & 4.5 & 3.8 \\
\hline 157 & 181 & 160 & 163 & J.P. STEVENS & 3.1 & 1.8 & 2.9 & 2.3 \\
\hline 212 & $\check{208}$ & 207 & 255 & UNITED MERCHANTS \& MFGS. & 3.2 & $(-)$ & 1.3 & $(-1$ \\
\hline 293 & 317 & 311 & 316 & SPRINJGS MILLS & 2.3 & 1.2 & 2.4 & 2.4 \\
\hline 297 & $\Xi 29$ & 287 & 281 & WEST POINT-PEPPERELL & 4.3 & 3.8 & $3.8^{\circ}$ & 3.3 \\
\hline 289 & $\Xi 31$ & 355 & & INDIAN HEAD & & 0.8 & 4.5 & \\
\hline 307 & $\Xi 38$ & 351 & 369 & M. LGWENSTEIN \& SONS & 1.4 & $(-)$ & 1.5 & $(-1)$ \\
\hline 378 & $\$ 09$ & 372 & 390 & DAN RIVER & 1.6 & $(-)$ & 1.8 & 2.2 \\
\hline 384 & 367 & 326 & 317 & CONE MILLS & 3.5 & 5.2 & 5.7 & 6.3 \\
\hline 410 & 415 & 393 & 393 & CANNON MILLS & 3.9 & 4.7 & 3.5 & 1.9 \\
\hline 439 & 441 & 440 & 416 & COLLINS \& AIKMAN & 4.0 & 0.7 & 4.9 & 4.2 \\
\hline 481 & 493 & 480 & 443 & FIELDCREST MILLS & 0.5 & 3.3 & 3.6 & 4.1 \\
\hline 496 & 482 & 455 & 446 & HANES & $(-1)$ & 3.4 & 4.9 & 5.0 \\
\hline 532 & 577 & 524 & 513 & RIEGEL TEXTILE & 3.4 & 3.5 & 5.2 & 4.2 \\
\hline 583 & 619 & 533 & 542 & GRANITEVILL: & 5.2 & 4.4 & 4.3 & 3.9 \\
\hline 574 & 642 & 627 & 621 & LUDLOW & 2.6 & $(-)$ & 1.5 & 0.3 \\
\hline 642 & $6 \overline{6} 6$ & 603 & 579 & REEVES BROTHERS & 4.6 & 1.6 & 4.1 & 3.8 \\
\hline 599 & $6 \hat{\mathrm{s} 2}$ & 670 & 727 & TEXF INDUST ZIES & $(-)$ & $(-)$ & $(-)$ & $(-1$ \\
\hline 610 & 6.37 & 779 & 897 & E.T. BARWICK ND. & $(-)$ & $(-)$ & $(-)$ & $(-1)$ \\
\hline 623 & $6: 91$ & 597 & 611 & AVONDALE MILLS & $(-)$ & 2.3 & 2.1 & 2.4 \\
\hline 582 & 6999 & 677 & 720 & CHELSEA INDLISTRIES & $(-)$ & 0.8 & 0.2 & 1.1 \\
\hline 777 & $i 77$ & 931 & & $B A T E S M F G$. & 7.9 & 5.5 & $(-)$ & $(-1$ \\
\hline 731 & $i 78$ & 745 & 714 & BIBB MFG. & 1.5 & $4.9^{\circ}$ & $(-1)$ & 1.5 \\
\hline 800 & $\varepsilon 57$ & 727 & 708 & TEXTILES & 4.1 & 3.7 & 6.7 & 6.9 \\
\hline 851 & 858 & 780 & 737 & DIXIE YARNS & 2.3 & 1.7 & 2.2 & 3.8 \\
\hline 908 & 952 & 897 & 951 & GUILFORD MILLS & $(-)$ & 0.3 & 3.0 & 3.2 \\
\hline
\end{tabular}

SOURCE: FORTUNE. 1975, 1976, 1977, 1978.

"DEERING MILLIKEN CORPORATION S A PRIVATE CORPORATION SO NO FIGURES ARE AVAILABLE. IT IS EST IMATED TO BE THE THIRD LARGEST COMPANY IN THE TEXTILE INDUSTRY, CLOSE TO

J.P. STEZIENS. 
TABLE 4-16

Profit on Stockholders' Equity

by Company and Year

\begin{tabular}{|l|rrr|}
\hline & \multicolumn{4}{|c|}{ NET INCOME AS A PERCENT OF } \\
& \multicolumn{3}{|c|}{ STOCKHOLDERS EQUITY } \\
& 1975 & 1976 & 1977 \\
\hline BURLINGTON INDUSTRIES & 4.4 & 10.8 & 8.9 \\
J.P. STEVENS & 4.8 & 9.3 & 7.6 \\
UNITED MERCHANTS \& MFGS. & $1-1$ & $1-1$ & $1-1$ \\
SPRINGS MILLS & 2.4 & 5.3 & 5.4 \\
WEST POINT-PEPPERELL & 8.4 & 10.7 & 10.0 \\
INDIAN HEAD & 2.6 & 11.6 & $1-1$ \\
M. LOWENSTEIN \& SONS & $1-1$ & 5.8 & $1-1$ \\
CONE MILLS & 13.7 & 16.2 & 18.4 \\
OAN RIVER & $1-1$ & 6.2 & 7.0 \\
CANNON MILLS & 7.0 & 6.1 & 6.6 \\
COLLINS \& AIKMAN & 2.0 & 14.1 & 12.7 \\
HANES & 10.9 & 16.3 & 15.9 \\
FIELDCREST MILLS & 10.4 & 12.1 & 15.2 \\
RIEGEL TEXTILE & 9.9 & 16.8 & 13.7 \\
GRANITEVILLE & 11.5 & 14.2 & 12.1 \\
LUDLOW & $(-1$ & 5.9 & 1.3 \\
REEVES BROTHERS & 4.2 & 12.1 & 11.6 \\
TEXFI INDUSTRIES & $1-1$ & $1-1$ & $1-1$ \\
E.T. BARWICK INDUSTRIES & $1-1$ & $1-1$ & $1-1$ \\
AVONDALE MILL & 5.4 & 6.8 & 7.4 \\
CHELSEA INDUSTRIES & 3.6 & 1.0 & 5.4 \\
BIBB MANUFACTURING & 11.8 & & 4.6 \\
TEXTILES & 3.7 & 18.7 & 18.4 \\
DIXIE YARNS & 5.6 & 8.7 & 15.6 \\
BATES MANUFACTURING & 17.4 & $1-1$ & $1-1$ \\
GUILFORD MILLS & 1.4 & 15.6 & 14.2 \\
\hline
\end{tabular}

SOURCE: FORTUNE, 1976, 1977, 1978. 
Further analysis of the narrow operating margin faced by various segments of the textile mill products industry is necessary at the level of the production process. This analysis can provide some insight into textile mill process economics and can therefore, give a better understanding of the industry.

As indicated earlier, the demand for textile mill products can shift abruptly. If a textile mill could shift production quickly in response to an unexpected change in demand, performance could be improved. But in a textile mill, shifts in production are difficult. Existing equipment may not have enough flexibility for a shift from production of one fabric to production of another. Furthermore, it is both time and lahnr intensive to alter the siviluliun prucess. In the fabric weaving process, for example, warp yarns are still tied in by hand in most cases. Dudley (1974) gives an excellent example of the problem faced by textile mills.

At the mill level, it is difficult and time consuming to change from production of 100 percent man-made fiber to production of 100 percent cotton fiber, or vice-versa. Major difficulties may even be encountered in shifting from production of man-made fiber-cotton blends to production of 100 percent cotton fabric. All of one fiber must be run out of the machines which are changing fiber and the machines must be thoroughly cleaned. 'l'his is a major undertaking and naturally quite timeconsuming. During the change, neither labor nor machines operate at peak efficiency. So once a mill shifts from cotton to man-made fiber in response to an anticipated price or supply movement, it is unlikely that the change will be reversed unless planners at the individual mill level peel they must do so to avert a severe profit squeeze or in response to strong consumer demand. This explains in part the apparent difficulty cotton experiences when attempting to recover markets in a specific end-use once it has been displaced. That is, the change is in response to anticipated longrun factors, and profit maximization drives would tend to counter the shutdown necessary to move back to cotton. This would also Exilain any laok of direct competitive shortrin lespunses by cotton and man-made fibers to seasonal price fluctuations.

Production shifts, then, are made in response to long-run but not short-run factors. 
In Tables 4-17 through 4-19, price indexes for the principal products and major cost components of three major textile mill products industry segments are summarized for 1975 through 1977. These segments are:

- Yarn spinning mills: cotton, man-made fibers, and silk (SIC 2281)

- Broadwoven fabric mills: cotton (SIC 2211)

- Broadwoven fabric mills: man-made fiber and silk (SIC 2221).

The tables show the relationship between prices and costs for these major industry segments and how they have changed over time.

A 1976 study of the textile mili products industry by SCS Engineers showed that, based on FTC data for 1974-75, the industry achieved an overall payback period of 5.6 years This corresponded to a return on capital of 4 percent.* By comparison, investments with a 3-year payback period required earning 7.5 percent on capital, and a 2-year payback required earning 11.2 percent on capital.

An interesting study of the textile and apparel industries by the Council on Wage and Price Stability in 1978 included an analysis of the current profitability of a textile mill producing woven greige cloth. The study indicated that a 12 to 15 percent rate of return on investment (ROI) is required by textile mills. Using this conclusion and adding a construction cost of $\$ 25$ million and a 6 percent annual operating cost increase, the council determined that greige broadwoven fabric prices would have to increase at 6.4 percent and 7.5 percent, respectively, to achieve the 12 and 15 percent ROI. However, the price of groige cotton hrnadwoven fabric increased only 1.7 percent from 1976 to 1977, and synthetic broadwoven gray fabric decreased by 1 percent during the period. This indicates that the economics of constructing a new greige broadwoven facility or making major capital improvements in such a facility are unfavorable.

* Return on capital is defined as net income after taxes as a percent of total capital (stockholders' equity plus long term debt). 
TABLE $\quad 4-17$

Price Indexes of Principal Products and Major Cost Components in Yarn Mills

(SIC 2281) 1975-1977

\begin{tabular}{|c|c|c|c|c|}
\hline \multirow{2}{*}{$\begin{array}{c}\text { PRINCIPAL PRODUCTS } \\
\text { (GRAY) }\end{array}$} & \multirow{2}{*}{$\begin{array}{c}1972 \\
\% \text { TOT } \\
\text { SHIPMENTS }\end{array}$} & \multicolumn{3}{|c|}{ PRICE INDEXES $(1972=100)$} \\
\hline & & 1975 & 1976 & 1977 \\
\hline CARDED COTTON YARNS & 21.8 & 125.5 & 162.9 & 164.9 \\
\hline COMBED COTTON YARNS & 12.5 & 121.6 & 157.5 & 162.2 \\
\hline RAYON AND ACETATE SPUN & & & & \\
\hline YARN & 8.7 & 112.0 & 168.3 & 169.4 \\
\hline ALL OTHER NONCELLULOSIC & - & & & \\
\hline SPUN YARN & 5.3 & 119.9 & 145.7 & 147.9 \\
\hline MAJOR COST COMPONENTS: & & & & \\
\hline MATERIALS: & & & & \\
\hline COTTON & 14.9 & 187.0 & 228.6 & 163.7 \\
\hline RAYON FIBER & 4.3 & 145.9 & 156.5 & 163.4 \\
\hline POLYESTER FIBER & 6.4 & 95.2 & 98.6 & 110.3 \\
\hline POLYESTER YARN & 4.2 & 98.3 & 61.9 & 75.1 \\
\hline FUEL AND ELECTRICITY & 1.7 & 225.0 & 245.0 & 284.0 \\
\hline BAYRULI.S & 23.0 & 128.1 & $135 . \overline{6}$ & 146.6 \\
\hline CAHITALCHARGE & 7.8 & . & & $\ldots$ \\
\hline
\end{tabular}

SOURCE: DEPARTMENT OF R.NMMEREE. 


\section{TABLE 4-18}

Price Indexes of Principal Products and Major cost Components in Cotton Broadwoven Fabric

(SIC 2211) 1975-1977

\begin{tabular}{|l|c|ccc|}
\hline \multicolumn{1}{|c|}{$\begin{array}{c}\text { 1972 } \\
\text { PRINCIPAL PRODUCTS }\end{array}$} & \multicolumn{4}{|c|}{ \% TOTAL } \\
SHIPMENTS & 1975 & 1976 & 1977 \\
\hline COTTON SHEETING & 20.0 & 112.3 & 137.8 & 139.6 \\
CARDED COLORED YARN & 6.4 & 158.2 & 186.7 & 209.8 \\
DYED AND FINISHED & 16.7 & 143.2 & 194.0 & 215.4 \\
FABRIC & 12.0 & 134.6 & 193.0 & 205.6 \\
TOWELS AND WASHCLOTHS & & & & \\
MAJOR COST COMPONENTS: & & & & \\
\hline MATERIALS: & 25.0 & 187.0 & 228.6 & 163.7 \\
COTTON & 3.9 & 95.2 & 98.6 & 110.3 \\
POLYESTER FIBER & 4.6 & 122.2 & 137.9 & 144.4 \\
SYNTHETIC YARN & 6.0. & 97.3 & 102.3 & 105.9 \\
PURCHASED FABRIC & & & & \\
FUELS AND ELECTRICITY & 2.2 & 225.0 & 245.0 & 284.0 \\
PAYROLLS & 8.0 & 128.7 & 140.4 & 152.8 \\
CAPITAL CHARGE & & $\ldots$. & $\ldots$. & $\ldots$ \\
\hline
\end{tabular}

SOURCE: DEPARTMENT OF COMMERCE. 
Price Indexes of Principal Products and Major Cost Components in Man-made and Silk Broadwoven Fabrics (SIC 2221) 1975-1977

\begin{tabular}{|c|c|c|c|c|}
\hline \multirow[b]{2}{*}{ PRINCIPAL PRODUCTS } & \multirow{2}{*}{$\begin{array}{c}1972 \\
\text { \% TOTAL } \\
\text { SHIPMENTS }\end{array}$} & \multicolumn{3}{|c|}{ PRICE INDEXES $(1972=100)$} \\
\hline & & 1975 & 1976 & 1977 \\
\hline $100 \%$ FILAMENT FABRICS & 13.3 & 124.0 & 146.8 & 142.7 \\
\hline COTTON & 26.0 & 140.0 & 104.7 & 103.2 \\
\hline FINISHED BROADWOVEN & 15.4 & 111.6 & 126.4 & 123.6 \\
\hline \multicolumn{5}{|l|}{ MAJOR COST COMPONENTS: } \\
\hline MATERIALS: & & & & \\
\hline COTTON & 6.4 & 187.0 & 228.6 & 163.7 \\
\hline POLYESTER FIBER & 5.4 & 95.2 & 98.6 & 110.3 \\
\hline RAYON YARN & 3.8 & 126.8 & 1.396 & 138.4 \\
\hline POLYESTER YARN & 3.8 & 98.3 & 61.9 & 75.1 \\
\hline SPUN YARN & 8.7 & 122.2 & 137.9 & 144.4 \\
\hline PURCHASED FABMIC & 3.8 & 97.3 & 102.3 & 105.9 \\
\hline FUELS AND ELECTRICITYY & $1 . \%$ & 225.0 & 245.0 & 284.0 \\
\hline PAYROLLS & 25.4 & 128.5 & 139.4 & 151.9 \\
\hline LAHIIAL CHARGE & 7.2 & . & $\ldots$ & . \\
\hline
\end{tabular}

SOURCE: DEPARTMENT OF COMMERCE. 

BOTH TIE FIRST AIJD SECOND TIERS OF THE TEXTILE MILL PRODUCTS IINDUSTRY

Textile waste can be used in two basic ways:

- Making fabric for the first tier of the industry

Reprocessed into products for use in the second tier of the industry.

\subsubsection{First Tier Waste Material Recovery}

The use of recycled material or fiber in new fabric lowers fabric quality, increases production costs, and reduces production efficiency. Information taken from a report by a private company and shown to investigators indicated that the reintroduction of damaged or short fibers into the various production processes could result in additional costs and operating problems. For example, besides the capital and operating costs of the equipment to process additional waste materials, the following problems could occur, resulting in increased costs:

- Increased cotton dust problems and the additional capital expenditures to meet OSHA standards

- Possible equipment damage and increased maintenance costs

- Increased waste, reducing production efficiency

- Reduced yarn quality (increased yarn breakage), increasing process down time and reducing labor and equipment efficiency in winding, warping, slakhing, and weaving operations.

Another private company report shown to the investigators indicated that merely changing the mix of cotton seriously affected production economics. The proposed change called for deleting California cotton from the U.S. cotton mix. Prior to the proposed change, the mix was 25 percent California cotton, 50 percent Arizona cotton and 25 percent Memphis cotton. The new ratio in the absence of California cotton was to be 50 percent each. The analysis concluded that a 1 percent increase in waste, a 2 percent decrease in spinning efficiency, and a reduction in yarn strength (causing increased breakage and poorer fabric yield) due to this proposed change could result in additional 
costs of more than $\$ 0.5$ million. The increased waste generated using waste fibers would be even more expensive due to the shorter fiber length. Furthermore, since product quality would be affected, the profit margin would ultimately be affected from the revenue side as well.

Since cotton and polyester fibers sell for 60 cents or more per pound and the waste by-product sells for only a fraction of that price, it would seem advisable, in a low margin industry, to use this waste in the production of new fabric. By mixing 60-cent cotton with less expensive cotton waste, a less expensive mix could be achieved.

In fact, major textile mills do use reworkable waste in the production process. However, primary and secondary waste is not used in the first tier indistry because it is not technically feasible to produce an acceptable product with these wastes. Given the low margin incentive toward improved waste utilization, if it were technically feasible, it would be done.

Because of the low margin in the textile mill products industry, increased use of waste to reduce costs is expected. Hore efficient equipment that generates less waste will be developed. Less waste will then be available, and waste prices will increase, reducing the margin between virgin and recycled material. This will further reduce the incentive to use recycled fiber. The quality of the waste will also be lower, due to the more efficient primary usage. Consequently, even fewer economic uses will exist for textile mill waste by 1987.

1.7.2 Gecond Tier iaste Material Recovery

'l'he generation of waste in the textile mill products and apparel industries has resulted in the development of the textile waste processing segment of the textile mill products industry. This segment is small relative to the industry as a whole. In 1976 it accounted for less than 0.5 percent of the total value of textile mill products shipments ( $\$ 166.2 \mathrm{million).} \mathrm{Material} \mathrm{costs} \mathrm{for} \mathrm{reprocessurs}$ are significantly higher than the industry average (71.4 percent compared to 61 percent for the whole industry). Furthermore, costs increased considerably over time from 62.5 percent in 1972 to 71.4 percent in 1976 . By comparison, material costs for the entire industry were 58.8 percent of the value of shipments in 1972, rising to only 61 percent by 1976. This reflects a 42 percent increase in materials costs for the reprocessors, compared with a 34.5 percent increase for the whole industry. 
Recycled textiles are high volume, low margin items. The increasing use of synthetics and synthetic blends has reduced the available quantity of pure cotton and wool wastes, which yield much higher returns. Waste prices vary tremendously depending on waste content. (Prices for waste textiles by fabric type are shown in Table 4-20.) For example pure cotton or wool materials have prices higher than that for mixed rags. The market for wiping cloths is probably the largest single market for old and new rags. Wiping cloth manufacturing is the most profitable segment of the rag collection industry:

In 1972 reprocessors paid salaries and wages amounting to 16.7 percent of the value of shipments. By 1976 the figure had increased to 18.4 percent. For the textile mill industry as a. whole, this percentage actually declined 6.4 percent.

\subsubsection{Waste Reprocessor Capital Expenditures}

Capital expenditures by textile waste reprocessors are low relative to those for the rest of the industry. In 1976, the ratio of capital expenditures to the value of shipments for the textile waste processors was 2.2 percent. For the industry as a whole, the ratio was 3.0. However, the cost of reprocessing equipment represents a significant expenditure in such a low margin industry. For example, a major textile machinery manufacturer indicated the installed costs of textile reprocessing equipment and machines are as follows:

Olympic pulling machine, 3 cylinder, Laroche model, total horsepower 183: Estimated installed cost is $\$ 138,000$.

CR 500 rotary cutter with metal detector, total horsepower 14: Estimated installed cost is $\$ 38,848$.

Cyclomatic, total housepower 58:

Estimated installed cost is $\$ 68,250$. 
TABLE 4-20

Textile Waste Price Changes

(January 1978 to January 1979)

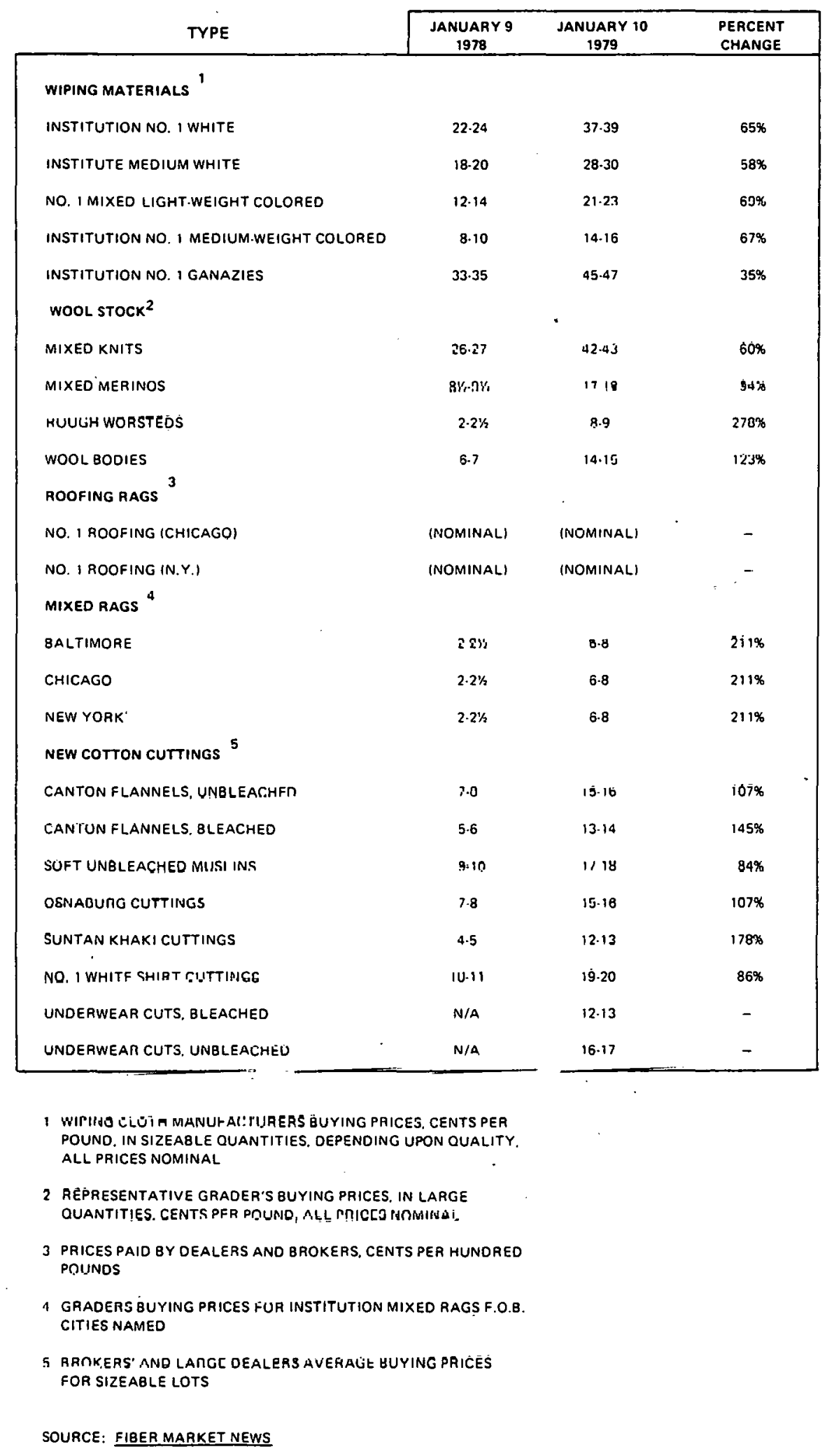


An additional 10 percent investment tax credit over the existing 10 percent credit (for a total of 20 percent) is in effect for expenditures associated with preparing material for recycling or actually recycling it. All sorting, processing, and other preparation equipment are covered whether they are involved in the recycling of primary waste or secondary waste.

\subsubsection{Waste Reprocessor Profit Margins}

As previously noted, the margins achieved by waste reprocessors are quite low. One producer's margin was no more than 7 to 10 percent, which he indicated was a minimum for survival. As waste prices have increased, the profit margins have been squeezed. Also, as synthetics and blended fabrics have increased in popularity, the percentage of high quality, high value waste has declined. Furthermore, transportation and handling costs, which are major elements of cost to the waste reprocessor, can seriously cut into profit margins.

Several examples of narrow margin on waste reprocessing were obtained from interviews with manufacturers of padding and upholstery stuffing. For example, black or grey polyester fiber sells for 9 to 12 cents per pound. Since the raw material costs less than 2 cents per pound, transportation costs 3 to 5 cents per pound,* and processing costs 5 to 7 cents per pound, there is clearly a very slim margin for profit.

Another manufacturer of shredded material and fiber stated that high quality material sells for 20 cents per pound. Since freight plus handling costs 2 cents per pound, this higher quality material is the only type that seems to justify an investment. Textured polyester is sold

\footnotetext{
* To transport these materials from Massachusetts to Balitmore or Philadelphia costs 3 to $3-1 / 2$ cents per pound. From Massachusetts to the South, the cost is 4 to $4-1 / 2$ cents per pound.
} 
by one processor for 6 cents per pound. Given costs for transportation ( 2 cents per pound), handling ( 1 cent), and baling ( 2 cent), only a penny margin is possible.

One processor noted that scraps and remnants from the apparel industry are purchased at 30 to 50 cents per pound. After cutting, sorting, and grading, they are sold as wiping cloths for 80 to 90 cents per pound.

\section{7 .2 .3 Summary}

In summary, then, waste reprocessing is a low margin business with transportation costs representing a large part of tot.al rnsts. The guality of waste has dctcriorated and will continue to do so and the industry will find it more and more difficult to obtain a suffieient return. Waste reprocessing, then, may experience some decline over the next 10 years, especially as incentives increase to use more waste in the primary sector. (The OSHA cotton dust standard may have an extremely detrimental effect on the waste reprocessing industry, especially since margins and capital availability are both already low.)

4.8

CAPITAL INVESTMENT IS NEEDED IIJ THE TEXTILE MILL PRODUCTS INDUSTRY, BUT ACCESS TO CAPITAL IS LIMITED

The textile mill products industry is in a very difficult situation with respect to capital investment. The industry is labor intensive, and labor costs have risen in the Inj.ted States, while competition from abroad has intensified. Therefore, there is a growing need for tenhnological change and modernization to improve productivity. The rising labor costs have forced manufacturers to adopt labor-saving technological improvements, which increase labor and equipment efficiency. Low profits have slowed the rate of capital investment and federal requlations have tended to consume whatever capital funds were available. Some investment for modernization does take place, and the domestic industry is less labor intensive than its foreign competitors. However, the industry is still relatively inefficient, when measured according to lahor intensity. Morr prndurtive mashirury and greater automation is needed. However, not only are the funds for such improvements not readily available, the productivity of the new machines is often not high enough to justify their very high costs. 
To assess the ability of the textile mill products industry to finance capital investment, the competing uses of capital and the alternative sources of that capital wi.l l be examined.

\subsubsection{Principal Uses for Capital Funds}

There are three principal competing uses for available capital funds:

- Capacity expansion

- Modernization of existing facilities

- Meeting government regulations and standards.

\subsubsection{Capacity Expansion}

Fiber consumption by U.S. textile mills has increased only 3 percent annually since 1969. The industry has been consistently able to increase capacity to match this rate of increase. Only in 1973 did man-made fabric production capacity fail to meet demand as buying accelerated in anticipation of potential shortăges due to the Mideast oil crisis. The capacity utilization rates since 1967 for the production of cotton and man-made fabrics are given in Table 4-21.. The demand for capital funds to keep capacity expansion abreast of growth is not expected to be a major problem for the industry.

Actually, the expansion of capacity is secondary to the immediate goal of improving production efficiency. Increases in efficiency are necessary if the industry is to remain competitive in the face of increasing labor costs and competition from foreign imports. However, capital expenditures are needed for new, high-speed equipment that is more versatile and dependable, since the use of such equipment can lower unit costs.

\subsubsection{Modernization of Existing Facilities}

The world textile mill products industry is excessively labor intensive in today's textile environment. The U.S. textile mill products industry is more efficient than the textile industries of many other countries, because of recen increased expenditures for modernization, but additional 
TABLE $4-21$

Capacity Utilization Rates 1967 to 1977

(Annual Average)

\begin{tabular}{|ccc|}
\hline YEAR & $\begin{array}{c}\text { COTTON } \\
\text { FABRICS }\end{array}$ & $\begin{array}{c}\text { MAN-MADE } \\
\text { FABRICS }\end{array}$ \\
\hline 1067 & 98.1 & 86.3 \\
1968 & 92.2 & 99.1 \\
1969 & 92.7 & 98.3 \\
1970 & 93.4 & 86.7 \\
1971 & 96.3 & 80.8 \\
1972 & 94.0 & 91.6 \\
1973 & 91.4 & 100.2 \\
1974 & 86.0 & 89.8 \\
1976 & 79.3 & 74.0 \\
1976 & 89.4 & 86.4 \\
1971 & 83.4 & 79.3 \\
\hline
\end{tabular}

SOURCE: FEDERAL RESERVE BOARD. 
spending is still needed. Table 4-22 indicates the share of capital spending for expansion and modernization since 1971. Modernization is taking a greater share each year, and this trend is expected to continue.

In recent years the purchase of textile machinery equipment has been significantly affected by the development of new fibers. The advanced equipment required for the processing of man-made fiber varies considerably.

Fashion trends have also been responsible for making some textile mill equipment obsolete. Knits and nonwovens require specialized equipment, but if the demand for these fabrics declines, the equipment will be idled. New machinery must be far more versatile if textile mill efficiency is to be improved. Decisions on the amount and type of capital expenditures are complex and risky, yet continued growth in the domestic textile mill products industry requires modernization. The more productive new machinery is very expensive, and only the largest firms are usually capable of generating the capital necessary to purchase it. If advances in machinery productivity, with their associated higher costs, continue there will be a tendency to concentrate the industry into fewer; more highly capitalized firms.

\subsubsection{Government Regulations and Standards}

Government regulations and standards requiring significant capital outlays will confront the textile mill products industry over the next decade. For example, the expenditures required to meet cotton dust, noise and pollution standards will reduce the amount available for productivity improvements. (Chapter 5 discusses government policies affecting the performance of the textile mill products industry.) The cotton dust standard, for example, could cost the industry more than $\$ 700$ million annually, according to USHA. Since annual capital expenditures are presently less than $\$ 1$ billion and estimates for 1987 are $\$ 2.4$ billion, compliance will be difficult for the industry. In addition, the noise control standard is estimated by osHA to require expenditures of $\$ 18$ to $\$ 34 \mathrm{million}$ annualiy. Other regulations discussed in Chapter 5 will require additional expenditures.

In summary, the competing demands for capital over the next decade will rapidly consume the available capital. Raising the funds necessary to meet these demands will be difficult, because access to capital is limited in the industry. 
TABLE 4-22

Capital spending for

Modernization and Expansion

(Percent)

\begin{tabular}{|cccc|}
\hline YEAR & $\begin{array}{c}\text { TOTAL } \\
\text { SPENUING }\end{array}$ & $\begin{array}{c}\text { EXPAN- } \\
\text { SION }\end{array}$ & $\begin{array}{c}\text { MODERNI- } \\
\text { ZATION }\end{array}$ \\
\hline 1971 & 610 & 39 & 61 \\
1972 & 730 & 32 & 68 \\
1973 & 770 & 31 & 69 \\
1974 & 840 & 30 & 70 \\
1975 & 680 & 14 & 86 \\
$1976 f$ & 790 & 27 & 73 \\
\hline
\end{tabular}

$f=$ FORECAST .

SUURCE: TEXTILE WORLD, JANUARY 1.976 AND U.S. DEPARTMENT OF COMMFRCE, SURVEY OF CURRENT BUSINESS. 


\title{
4.8.2 Sources of Capital
}

There are four potential sources of capital for the industry to consider:

\author{
Equity markets \\ Long term debts \\ Retained earnings \\ Depreciation.
}

Historically, neither equity markets (stocks) nor long term debts (bonds) have been reliable sources of funds. The relatively low rate of return in the textile mill products industry has made raising capital from external sources difficult.

The common stocks of textile companies have been selling well below their book value. An analysis of seven major textile companies by Merrill Lynch in May 1978. indicated that textile issues were selling at discounts from book value (per share) ranging from 1 to 60 percent. As long as most shares continue to sell below their book value, the equity market is not likely to generate significant amounts of capital for textile companies.

Bonds from textile mill product companies are also considered unattractive investments. Standard and Poor's bond quality ratings for the major textile companies show a few top firms with $A$ ratings, but most others have $B B$ or $\mathrm{BBB}$. The number of firms qualifying for long term debt is very small.

The ratio of long term debt to stockholders' equity (i.e., the debt/equity ratio) in the textile mill industry is about 33 percent. In general, it is desirable to have a high percentage of long term debt relative to stockholders' equity, because a high degree of leverage provides greater growth potential. However, in the textile mill products industry, dividend paymonte are higher than they are in all manufacturing. The payments are kept high to encourage investment (see Table 4-23). Textile bond issues, by comparison, have unattractive quality ratings. The net result is the conservative 33 percent debt to equity ratio.

Internal sources of funds include retained earnings and depreciation. About 80 percent of all the funds available to textile mill products firms are internal funds. Since the industry is a low margin business, retained earnings are generally low. Dividend payments are not reduced proportionally when profits decline. Textile firms feel that this is necessary to maintain continued investment interest. Consequently, retained earnings may be especially low in lean years. 
TABLE 4-23

Dividend Payments for the

Textile Mill Products Industry vs

Those For All Industry

(Percent of Earnings)

\begin{tabular}{|c|c|c|}
\hline & $\begin{array}{c}\text { ALL } \\
\text { INDUSTRIALS }\end{array}$ & $\begin{array}{c}\text { TEXTILE } \\
\text { COMPANION }\end{array}$ \\
\hline 1977 & 43.0 & 40.4 \\
1976 & 39.5 & 30.7 \\
1975 & 43.4 & 67.5 \\
1974 & 38.6 & 36.0 \\
1973 & 38.9 & 38.1 \\
1972 & 47.1 & 63.4 \\
1971 & 52.9 & 99.3 \\
1970 & 59.2 & 69.2 \\
1969 & 53.0 & 57.4 \\
1968 & 51.3 & 51.0 \\
\hline
\end{tabular}

SOURCE: STANDARD \& POOR'S INDUSTRY SURVEY: TEXTILES, JULY 13, 1978 
Depreciation is the primary source of funds used for plant and equipment investments. However, equipment costs have increased rapidly over the years. Table 4-24 shows the rapid escalation of textile equipment costs since 1960. Given the increased costs of textile machinery, depreciation is inadequate to finance the replacement of old, outdated equipment.

Since the demand for capital funds is high relative to the supply, the textile mill products industry will find financing even the most necessary capital expenditures quite difficult over the next 10 years.

In this chapter, the nature, structure, and economic performance of the textile mill products industry was examined. The ability of the industry to finance capital investments was also discussed. In the following, chapter, the effect of government regulatory policies on industry operations and the use of recovered materials will be examined. 
TABLE 4-24

Cost Increases for Textile Mill Equipment

(1960 to 1974)

\begin{tabular}{|lcr|}
\hline \multicolumn{1}{|c}{ EQUIPMENT } & \multicolumn{2}{c|}{ BASIC COST } \\
\multicolumn{1}{|c|}{1900} & 1974 \\
\hline $\begin{array}{l}\text { NEW, HIGH-SPEED CARD } \\
\text { WITH SUCTION CLEANING } \\
\text { HIGH-SPEED DRAWING/ }\end{array}$ & $\$ 9,000$ & $\$ 30,000$ \\
DELIVERY & 2,200 & 5,500 \\
ROVING/SPINDLE & 125 & 490 \\
CONVENTIONAL SPINNIING & & \\
SPINDLE & 40 & 90 \\
64" X-3 LOOM & 3,800 & 6.900 \\
85" SULZER LOOM & 14,000 & 34,000 \\
TEXTURIZING/SPINDLE & 250 & 1,000 \\
\hline
\end{tabular}

SOURCE: STSATEMENT BY JOHN M. HAMRICK FOR ATMI BEFORE HOIISF WAYS \& MEANS COMMITTEE JUL'Y 23, igi/b. 


\section{CHAPTER 4 SOURCES}

1. American Textile Manufacturers Institute, Economic Information Division, Textile Hi-Lights, December 1978 .

2. Arnold Bernhard and Co., Inc., The Value Line Data Bases, 1978 .

3. Conversations and correspondence with representatives of the following associations:

- American Yarn Spinners Association
- Cordage Institute
- Mnternational Non-Wovens and Disposables Association
Man-Made Fiber Producers Association

4. Conversations with various private manufacturers of textile mill products.

5. Conversation with representatives of the following:

- Economic Research Service

(U.S. Department of Agriculture)

- Federal Trade Commission

- Office of Textiles

(U.S. Department of Commerce)

6. Conversations with various textile waste reprocessors.

7. G. Danielowski, "Recovering Fiber Waste for Spinning," Textile Industries, October 1978.

8. George E. Dudley, U.S. Textile Fiber Demand: Price Elasticities in Major End Use Markets, U.S. Department of Agriculture, Economic Research Service, Technical Bulletin No. 1500, September 1974 .

9. Energy and Environmental Analysis, Inc., Investment Risk Evaluation Techniques: Use in Energy-Intensive Industries and Implications for ERDA's Industrial Conservation Program, Prepared for U.S. Department of Energy, July 13, 1977 .

10. Federal Trade Commission, "Hart-Scott-Rodino Antitrust Improvements Act of 1976," Federal Register, July 31, 1978 . 
11. "Fortune," The Largest Industrial Corporations, 1975, $1976,1977,1978$.

12. Harvard Business School, Textile Industry Reference Note, 1977.

13. L.D. Howell, The American Textile Industry, U.S. Department of Agriculture, November 1964.

14. Stephen J. Hudak, and Paul T. Bohnslav, Supplement: The Textile Industry: A Study of Capital Investment Technology and Other Factors Affecting Prescribed Capital Recovery Allowances of Textile Machinery, U.S. Treasury Department, Office of Tndustrial Economics, February 2, 1976.

15. Stephen J. Hudak, and Paul T. Bohnslav, The Textile Industry: A Study of Capital Investment Technology and Uthor Factor3 Affecting fieseived Capital Recovery Allowances of Textile Machinery, U.S. Treasury Department, Office of Industrial Economics, February 2, 1976.

16. Interview with Dr. Carl Dyer, School of Textiles, North Carolina State University. Raleigh, North Carolina.

17. Market News Publishing Corporation, Fiber Market News, January 9, 1978 and January 10, 1979.

18. "Business Week," Corporate Balance Sheet Scoreboard, October 16, 1978 .

19. McGraw-Hill, 25th Annual Survey: Business Spending Plans for Plants and Equipment, November 6, 1978 .

20. Merrill, Lynch, Pierce, Fenner \& Smith, Inc., Textile Industry: A Statistical Comparison, May 1978.

21. Urganization for Economic Cooperation and Development, Impact of Changes in Availability and Prices of Energy and Textile Raw Materials on the Future Activities of the Textile and Clothing Industry, 1976.

22. Vivian C. Pospisil, "2000 Future Focus: Do Textiles Face a Fraying Future?" Industry Week, July 24, 1978.

23. Predicasts, Inc., 1978 Annual Cumulative Edition, Tuly 28, 1978 . 
24. SCS Engineers, Inc., Energy Efficiency Improvement Target in the Textile Mill Products Industry SIC 22. 1977 .

25. Standard and Poor's, Industry Survey: Textiles, July 13, 1978 .

26. Hal Taylor, "Government Opens Monopoly Probe of Manmade Fibers," Daily News Record, January 11, 1979.

27. Textile Economics Bureau, Inc., Textile Organon, November 1978 , December 1978.

28. Textile World, "Textiles" Whose Business by 1980?"

29. U.S. Department of Agriculture, Cotton and Nool Situation, December 1978 .

30. U.S. Department of Agriculture, Supplement for 1978: Statistics on Cotton and Related Data, 1920-1973, Statistical Bulletin No. 535, March 1978.

31. U.S. Department of Commerce, 1972 Census of Manufactures, 1972 .

32. U.S. Department of Commerce, 1976 Annual Survey of Manufactures: Industry Profiles, June 1978 .

33. U.S. Department of Commerce, 1979 U.S. Industrial Outlook, January 1979 .

34. U.S. Department of Commerce, Survey of Current Business, 1962 through 1978.

35. U.S. Department of Commerce, U.S: Production, Imports, and Import/Production Ratios for Cotton, Nool, and Man-Made Fiber Textiles and Apparel, January $19 \% \overline{8}$.

36. Lionel F. Ward, and Gordon A. King, Interfiber Competition with Emphasis on Cotton: Trends and Projections to 1980, U.S. Department of Agriculture, December 1973.

37. Barry P. Bosworth, Textiles/Apparel: A. Study of the Textiles and Apparel Industries, Council on liage and Price Stability, July 1978. 


\section{GOVERNMENTAL AND REGULATORY INFLUENCE ON THE U.S. TEXTILE INDUSTRY}

The federal government, through its departments, agencies, and commissions, has a significant influence on the textile mill products industry. This influence may be direct, transmitted through regulations, policies, and ruling aimed specifically at the various sectors of the industry. It may also be indirect, resulting from policies that, although primarily aimed at other sectors of the economy or other industries, still influence the production and marketing of textile products.. This chapter investigates the various agencies of government that have a direct influence on the industry. The level of detail presented for each agency depends on the degree of its influence on the textile mill products industry, and especially on how much the agency's policies may affect the materials recovery targets. The information presented may be used in combination with analyses in other chapters of this report to develop a.clearer understanding of the industry's potential for reusing recovered materials.

Each agency can generally affect materials recovery in either a positive or a negative way. With regard to the recycling of textile fibers and products, existing government policy exerts a generaliy negative influence on the textile mill products industry. This is due either to policies that clearly prohibit the use of recycled materials or to the capital requirements that result from certain regulations. At times these requirements are so large that materials recovery technology must be given a low priority by the industry. Actions necessary to reverse this trend include outright appeal or amendment of certain acts and/or granting of subsidies to the industry to meet its capital requirements. However, the industry has thus far failed in both of these areas.

5.1 SEVEPAL AGENCIES OF THE PEDEPAL GOVERNMENT IMPACT THE USE OF RECOYERED MATERIALE IN THE TEXTILE MAILL PRODUCES INTUSTSY

The major agencies of government that influence or affect the textile mill products industry through regulations, policies, or rulings are as follows: 


Environmental Protection Agency
- $\quad$ Dederal Trade Commission
- Department of Labor
- $\quad$ Treasury Department
- $\quad$ Consumer Product Safety Commission
- Department of Defense
Department of Energy.

In the following sections, each of these agencies is discussed with respect to its influence on the industry.

\subsubsection{Environmental Protection Agency}

'l'he Environmental Frotection Agency (EPA) has two basic policies that directly affect the ability of the textile mill products industry to implement recovered materials practices. These are its regulation policy on hazardous waste management and its regulation policy on effluent guidelines, pretreatment standards, and performance standards. These policies are discussed in the following paragraphs.

\subsubsection{Rules and Regulations on Hazardous Waste Management}

Undor Subtitle C UF the Resource Conservation and Recovery Act (RCRA) of 1976, EPA is required to investigate several areas relating to industriol hazardous waste generation. The textile mill products industry is one such area.

Undor Scction 3001 UI RERA, E'HA has prepared a list of hazardous wastes for each industrial category. The sluage generated from textile waste-water treatment processes has been included on this list as a "hazardous waste." Under Section 3002 of the act, EPA is currently investigating treatment options that will make textile sludge amenable to resource recovery. The results of this analysis could require the industry to make adritional capitol. inveslments in order lo comply with the standards and permit requirements for treatment, storage, and disposal of hazardous waste. In this respect, the regulations could be considered a negative factor for materials recovery. The competition for capital to comply with these hazardous waste regulations will make it more difficult to obtain capital for materials recovery technology. 
It may appear that the National Energy Conservation and Policy Act (NECPA), under which the materials recovery target setting is mandated, and RCRA, under which resource recovery from hazardous wastes is mandated, have similar purposes and objectives and that they should therefore exert positive influences on each other. That is true with regard to the overall objectives of resource recovery - reducing and controlling solid waste. However, materials recovery is actually directed at recycling waste fibers, while RCRA is directed at recovery of useful materials from textile sludge other than fibers. In actuality, then, the two laws will probably exert negative influences on each other as they will intensify competition for scarce capital to implement new technology. Moreover, since textile waste sludge has been designated "hazardous," it does not qualify as solid waste as defined in NECPA.

5.1.1.2 Rules and Regulations on Effluent Guidelines, Pretreatment standards, and Standards.of Performance

The Clean Water Act. of 1977 expanded the spectrum of pollutant parameters in point source discharges that are to receive attention to include potentially toxic compounds, and groupings originally identified in the consent Decree in NRDC vs Train (8 ERC 2120, D.D.C. 1976) have been made subject to effluent limitations. Of 232 pollutant categories, 65 were selected as the most important. They were selected because they were judged to be of the greatest environmental concern. The selections were based on the following criteria:

- "Substances for which there is substantial evidence of carcinogenicity, mutagenicity, and/or teratogenicity

- "Substances structurally similar to the aforementioned compounds or for which there is some evidence of carcinogenicity, mutagenicity, or teratogenicity

"Substances known to have toxic effects in sufficiently high concentrations and which are present in industrial effluents."

Within the 65 classes, 129 specific elements or compounds were identified as priority pollutants. These included 13 metals, 114 organic compounds, cyanides, and asbestos. 
The priority pollutants judged to be most significant in textile mill wastewaters are the following:

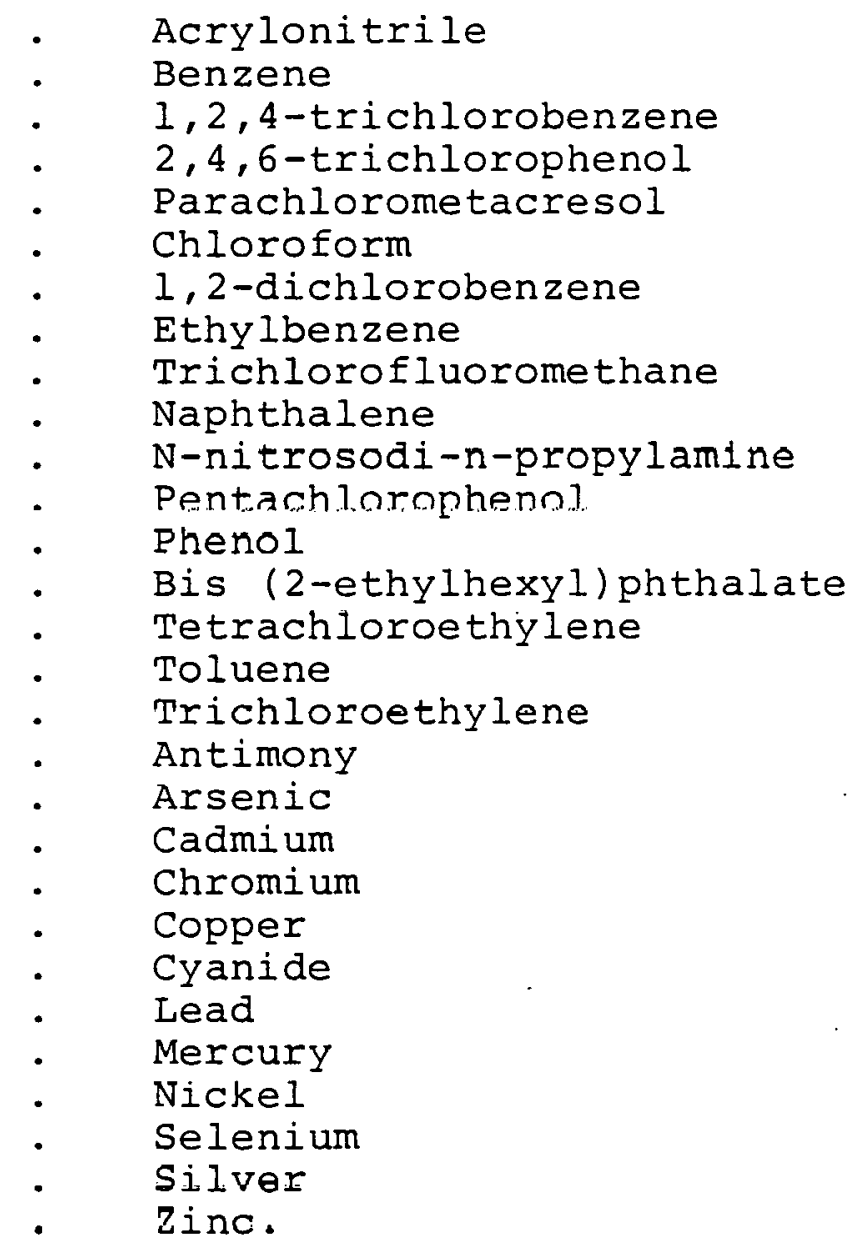

EPA is now concluding its analysis of control and treatment technologies that are applicable for these priority pollutants in the textile industry. Treatment technologies recommended to remove or reduce these pollutants and the costs of application of these technologies for a full range of mill sizes are being estimated.

The regulations to be published by EPA under Sections $301(b)$ and (d), 304(b), 306, and $307(b)$ and (c) of the Federal Water Pollution Control Act, as amended, will be based in part on the EPA report and on the comments received relative to the report. EPA will also consider economic and environmental impact information that is presently being developed. After review and evaluation of the technical, economic, and 
environmental information, an EPA report will be drafted. The report will. set forth EPA's preliminary conclusions regarding the textile industry. The proposed rules will include effluent guidelines and standards, standards of performance, and pretreatment standards applicable to the industry. These rules will have a direct effect on the textile industry, probably in the early 1980's, and will add to its escalating capital requirements, primarily in the finishing and dyeing sectors, where wet processes are employed. The dry processing sector (spinning and weaving) should not be affected significantly by these forthcoming EPA regulations.

Preliminary estimates of capital requirements to implement these regulations vary, and better estimates will be presented in the EPA analysis. However, the National Commission on Water Quality, in their annual report in 1975, estimated that the capital expenditures necessary to meet the 1983 water-related standards would be between $\$ 528$ and $\$ 785$ million, with annual operating and maintenance expenditures between $\$ 50$ and $\$ 81$ million for the years 1977-1982. Although it is difficult to know exactly which industry sectors will be affected the most, recycling technology will probably be given a lower priority in the competition for already scarce capital to meet the EPA regulations.

\subsubsection{Federal Trade Commission}

The Federal Trade Commission (FTC) has a considerable impact on the U.S. wool processing industry through two basic labeling acts. These textile-related labeling acts are the Wool Products Labeling Act and the Textile Fiber Products Identification Act. They are discussed in the following paragraphs.

\subsubsection{Wool Products Labeling Act of 1939,}

The basic purpose of the Wool products Labeling Act is to prevent unlawful and unfair competition among producers of wool products. Among other things, the law requires strict labeling that gives the origin of the wool used in wool fabric. The act also requires that the designations "reused" and "reprocessed" appear on labels of all wool products if they are not made of "new" or "virgin" wool. 
The act and the validity of these designations have been debated for many years. The latest argument. was in November 1973, when hearings were held before the Senate subcommittee on commerce and Finance for purposes of amending the Act. An amendment was sponsored by two senators representing states where wool reprocessing was a dominant, if declining, industry. The basic theme of the amendment was that the word "recycled" should be substituted for the words "reused" and "reprocessed." The contention of the sponsors of the bill was that the latter two words were confusing to the public and discriminated against the reuse of wool waste products. Excerpts from the hearings indicate the nature of the debate.

From Representative Peter Kyros, State of Maine, a sponsor of the bill:

.. Our bill wuuld simplify the labeling of woolen products by substituting the term "recycled" wool for the now often confusing terms of "reused" and "reprocessed" wool. This bill in no way changes the definition of wool. Speaking as a layman, I would find it difficult to explain the differences between "reused" wool and "reprocessed" wool. Our bill would end the confusion by substituting a term all consumers understand. The current situation creates considerable difficulty since some shoppers equate "reused" wool (from used and discarded garments) with "reprocessed" wool (from garments never utilized by the ultimate cunsumer). While this bill, H.R. 9934, would be of benefit to woolen mills across the country it would provide substantial assistance to the hardpressed textilie industry in the Northeast since this is the area of heavicet concentration for the woolen industry.

From R. Reed Grimwade, Vi.ce President of the Northern Textile Association, in favor of the bill:

...We believe that the term "recycled" is a more accurate description frum the consumer's viewpoint as well.

We make a good product which provides warm coats, jackets, shirts, blankets, and other items within the budget of lower income families and other economy mindcd customers. Recycled wool is also worn by lumberjacks and others engaged in 
outdoor occupations as well as in safety clothing to guard against heat and molten metal in steel mills and other similar occupations.

Imported wool fabrics and apparel are not labeled "reused" and are invariably labeled as "wool" or "reprocessed wool." Such products frequently contain "reused wool" but there is no practical way for Customs to police this. Neither Customs nor the FTC has the same access to the records of foreign mills as the FTC has to records of domestic mills. In view of the fact that these imports constitute about one-third of U.S. consumption we believe it is more equitable to have the single term "recycled."

We assert that microscopic tests of fiber damage offer no evidence or proof of whether a fabric is made of reprocessed wool as contrasted with reused wool. The amount of fiber damage tells us nothing in such fabrics.

From the FTC, in opposition to the bill:

... Under the present Act "reprocessed wool" is defined as "...the resulting fiber when wool has been woven...into a wool product which, without ever having been utilized in any way by the ultimate consumer, subsequently has been made into a fibrous state." "Reused wool" refers to such a fiber which has "...been used by the ultimate consumer." "Reprocessed wool" and "reused wool" are not simply different terms which mean the same thing. They are descriptive of quality differences in wool fibers. According to laboratory tests published in the Wool Handbook, there are approximately three times as many damaged fibers in reprocessed wool as in virgin wool. As the number of damaged fibers in a product increases, the quality of the product decreases.

.. The staff of the commission is currently studying the use of the word "recycled" to describe products in general. The preliminary indication is that it is essential to have definitive meanings for "recycled" which are applicable, insofar as possible, to all products. In addition, it is apparent that a product which is described as recycled should be comparable to a new product of 
the same type insofar as utility and consumer acceptance. The staff is studying the various means of achieving this objective. The Commission is concerned that if both reprocessed wool and reused wool can be described as recycled wool, this may have the effect of tainting the word "recycled" by allowing it to be used to describe lesser quality products. This could be detrimental to any overall program designed to encourage recycling.

...Therefore, the Commission opposes the proposed amendments for the following reasons: (1) The terms "reprocessed wool" and "reused wool." describe fihers of different qualities. (2) The consumer should be completely informed, insofar as is practicable, as to the origin of wool fibers found in wool products. The proposed amendments would in the Commission's opinion result in consumers receiving significantly less information than they get now. (3) We believe that it is essential to apply the word "recycled" only to products which are substantially the same in utility and in consumer acceptance as new products of the same type.

This bill was never passed from subcommittee, and the original provisions of the act requiring the controversial labeling are still in effect.

The act is judged to be a negative factor in the increased use of materials recovery, at least for industries engaged in the production of woolen textiles. Its strict labeling requirements have helped to reduce the wool industry so much that today wool fibers make up only about I percent of all fiber demand and half of that is imported from foreign countries.

\subsubsection{Textile Fiber Products Identification Act}

The Textile Fiber Products Identification Act addresses identification and labeling of textile products other than those made from wool fiberschiefly cotton and man-made fibers. The use of recycled or reused materials is noted twice in this act under two rules: 


\section{Rule 32 -Products Containing Reused Stuffing}

- Rule 35-Use of Terms "Virgin" or
"New."

Rule 32 requires that any upholstered product, mattress, or cushion that contains stuffing that has previously been used as stuffing must have a conspicuous label attached bearing the words "reused stuffing" or "previously used stuffing." This requirement has apparently caused little or no problem for producers or consumers, since "original stuffing" is being used by the producers of these items, the producers apparently seeing little need to utilize "reused stuffing."

Rule 35 prohibits the use of the word "virgin" or "new" when the product so described is not composed wholly of new or virgin fiber. That is, the fiber must never have been reclaimed from any spun, woven, knitted, felted, bonded, or similarly manufactured product.

The interesting point about this provision, unlike that in the Wool Labeling Act, is that this act stipulates only what a label cannot say, not what it must say. There is no provision for the words "reused" or "reprocessed" in the Textile Fiber Products Identification Act, and consequently it cannot be said to discourage materials recovery. Since it does nothing to encourage the use of recycled fibers, the act's overall effect on materials recovery is neutral.

\subsubsection{Deparlment of Labor}

The OSHA cotton dust and noise standards will greatly impact the use of recovered materials in the textile mill products industry. These standards are discussed in the sections that follow.

\subsubsection{OSHA Cotton Dust Standards}

In the Federal Register of June 23, 1978 (43 FR 27350), the Occupational Safety and Health Administration (OSHA) published a final occupational safety and health standard, pursuant to section 6 (b) of the act, regulating worker exposure to cotton dust. The standard applies 
to all industries in which employees are exposed to cotton dust, with certain specified exceptions, and requires employers to take prescribed measures to control employee exposure to cotton dust. The standard was effective september 4, 1978, and, with limited exceptions, was applicable to all nontextile industries,. including cottonseed oil mills, and the textile mill products industry. The permissible exposure limits are shown in Table 5-1 along with other essential provisions of the standard.

- On August 21, 1978, OSHA received a request for an administrative stay of the standard from the National Cotton Batting Institute and the Textile Fibers and By-Products Association. The request was made on behalf of tlie cotton waste processing industries and employers who are purchasers and users of batting containing cotton. This request brought to osHA's attention a draft report prepared by the National Institute of Safety and Health (NIOSH). The report concerned health hazards experienced by the Stearns and Foster Company's garnetting and mattress workers. This report was not available prior to promulgation of the final standard. Upon preliminary review of this report, OSHA determined that the information it presented warranted further review and analysis. This new evidence was received after the close of the cotton dust record and therefore did not have to be considered as part of this proceeding, but nSHA choec to invile comment on its significance and, in the meantime, to suspend the cotton dust standard as it pertained to the waste processing 1hdustries and users of cotton batting. NIOSH submitted a final version of the health hazard evaluation on August 31, 1978.

After additional analysis and commenting by the industry and the public, OSHA concluded that there was no basis for permanently sluspending the gollun dust standard for the waste processing industries and users of cotton batting. OSHA concluded with NIOSH that the OSHA standard must be complied with in order to ensure adequate worker safety and health. Currently lhe cotton dust standard is under a judicial stay while the courts consider its dppeal and, although the outcome is uncertain, full compliance by the industry is expected to be required over time. 
TABLE 5-1

Essential Provisions of the

osHA Cotton Dust Standard

Section

1

2

3

4

5

6
Provisions

Medical examination and ventilatory function tests before placement and after 6 weeks for new employees; annual medical examination for all employees; retention of medical records for 20 years.

Posting of warnings of potential exposure to cotton dust.

Personal protective equipment (respirators) for workers exposed to cotton dust concentrations in excess of the prescribed limits.

Informing employees of hazards from cotton dust.

Work practices to minimize employee exposure.

Occupational exposure to lint-free cotton dust. (dust less than $15 \mu \mathrm{m}$ aerodynamic diameter) shall be controlled to the lowest feasible limit as noted below. Required sampling collection and analysis methods are also prescribed.

\begin{tabular}{|c|c|c|c|c|c|}
\hline \multicolumn{2}{|c|}{$\begin{array}{l}\text { Exposure } \\
\text { Limits }\end{array}$} & $\begin{array}{l}\text { Major Industry } \\
\text { Group Affected }\end{array}$ & Major & SICs & Affected \\
\hline 0.2 & $\mathrm{mg} / \mathrm{m}$ & Yarn manufacturing & $\begin{array}{l}2211, \\
2201,\end{array}$ & $\begin{array}{l}2221 \\
2284\end{array}$ & $\begin{array}{l}2257 \\
2296\end{array}$ \\
\hline 0.5 & $\mathrm{mg} / \mathrm{m}$ & Waste processing & 2293 & 2294 & \\
\hline 0.75 & $\mathrm{mg} / \mathrm{m}$ & Weaving & $\begin{array}{l}2211 \\
2296\end{array}$ & 2221 & 2241 \\
\hline
\end{tabular}


In accordance with Executive order 11821, Inflationary Impact Statements, OSHA prepared a technological feasibility assessment and inflationary impact analysis of the cotton dust standard. Significant conclusions from that study included the position that feasible dust control measures could be developed to meet the 0.2 $\mathrm{mg} / \mathrm{m}^{3}$ and $0.5 \mathrm{mg} / \mathrm{m}^{3}$ standards as well as the $0.75 \mathrm{mg} / \mathrm{m}^{3}$ standard. However, due to the very limited experimentation done with local exhaust ventilation controls, it appears that these control processes will become available only after a considerable period of development. Having determined the technological feasibility of meeting the standards, OSHA considered compliance costs, with results as shown in Table 5-2. This table includes cotton ginning, which is not parl of the SIC 22 category, but is put in the exhibit for purpnaes of comparison. The $0.1 \mathrm{mg} / \mathrm{m}^{3}$ standard is also shown in the table because it was an earlier NIOSH recommendation. It was subsequently dropped from consideration.

The textile mill products industry claims that the technology for cotton dust control to the limits prescribed by OSHA is not adequately developed and that the costs to implement the provisions of the standards cannot be absorbed by the industry. OSHA appears to feel that those arguments are not valid. To the degree that additional financial burdens are imposed on the cotton textile industries, the cotton dust standard must be considered a negative factor in the development of incredsed materials recovery. Many of the smaller waste-processing firms may discontinue handling cotton wastes if they cannot justify the costs of implementing required dust control technology.

A weaving firm specializing in cotton and yarn epinning that tries to comply with the cotton dust standards will be likely to experience costs well in excess of profits. Depending on the size of the company, these costs may range from 10 to 20 times the profits (after taxes) of that company. The grcatest financial impact will be on the smaller firms, but obtaining compliance capital will be diffirult for the entire 1ndustry.

\subsubsection{OSHA Noise Standard}

A more significant capital burden may be experienced by textile manufacturers in the area of noise abatement 
TABLE 5-2

Total Installed and Annualized Compliance Costs of OSHA Cotton Dust Standard

(Cost in Millions of Dollars)

\begin{tabular}{|c|c|c|c|c|c|c|}
\hline INDUSTRY SECTOR & $\begin{array}{l}\text { EXPOSURE } \\
\text { LIMIT } \\
\text { (MG/M } / M^{3} \text { ) }\end{array}$ & $\begin{array}{l}\text { INSTALLED } \\
\text { COST }\end{array}$ & $\begin{array}{l}\text { ANNUALIIZED } \\
\text { CAPITAL } \\
\text { CHARGE }\end{array}$ & $\begin{array}{l}\text { DIRECT } \\
\text { OPERATING } \\
\text { COST }\end{array}$ & $\begin{array}{c}\text { ENERGY } \\
\text { COST }\end{array}$ & $\begin{array}{c}\text { TOTAL } \\
\text { ANNUALIZED } \\
\text { COST }\end{array}$ \\
\hline YARN PRODUCTION & $\begin{array}{l}0.5 \\
0.2 \\
0.1\end{array}$ & $\begin{array}{r}211.8 \\
984.4 \\
2,802.7\end{array}$ & $\begin{array}{r}33.8 \\
158.3 \\
450.6\end{array}$ & $\begin{array}{r}6.9 \\
15.6 \\
23.3\end{array}$ & $\begin{array}{r}20.6 \\
67.9 \\
147.0\end{array}$ & $\begin{array}{r}61.5 \\
241.6 \\
620.6\end{array}$ \\
\hline COTTON GINNING & $\begin{array}{l}0.5 \\
0.2 \\
0.1\end{array}$ & $\begin{array}{r}16.9 \\
292.2 \\
343.6\end{array}$ & $\begin{array}{r}2.7 \\
47.0 \\
55.2\end{array}$ & $\begin{array}{r}4.9 \\
13.2 \\
14.7\end{array}$ & $\begin{array}{r}1.8 \\
30.3 \\
35.4\end{array}$ & $\begin{array}{r}9.4 \\
90.4 \\
105.3\end{array}$ \\
\hline COTTON WEAVINIS & $\begin{array}{l}0.5 \\
0.2 \\
0.1\end{array}$ & $\begin{array}{r}9.1 \\
1,387.9 \\
3,939.1\end{array}$ & $\begin{array}{r}1.5 \\
223.1 \\
633.2\end{array}$ & $\begin{array}{r}1.7 \\
40.7 \\
112.6\end{array}$ & $\begin{array}{r}0.6 \\
86.3 \\
245.1\end{array}$ & $\begin{array}{r}3.7 \\
350.1 \\
990.9\end{array}$ \\
\hline WASTE PROCESSING & $\begin{array}{l}0.5 \\
0.2 \\
0.1\end{array}$ & $\begin{array}{l}17.3 \\
32.0 \\
56.1\end{array}$ & $\begin{array}{l}2.8 \\
5.2 \\
9.0\end{array}$ & $\begin{array}{l}2.6 \\
2.9 \\
3.4\end{array}$ & $\begin{array}{l}2.5 \\
4.7 \\
8.2\end{array}$ & $\begin{array}{r}7.9 \\
12.8 \\
20.6\end{array}$ \\
\hline TOTAL & $\begin{array}{l}0.5 \\
0.2 \\
0.1\end{array}$ & $\begin{array}{r}255.1 \\
2,696.5 \\
7,141.5\end{array}$ & $\begin{array}{r}40.8 \\
433.6 \\
1,148.0\end{array}$ & $\begin{array}{r}16.1 \\
72.4 \\
154.0\end{array}$ & $\begin{array}{r}25.5 \\
189.2 \\
435.7\end{array}$ & $\begin{array}{r}82.5 \\
694.9 \\
1,737.4\end{array}$ \\
\hline
\end{tabular}

NOTE: EXPOSURE LIMIT $0.1 \mathrm{MG} / \mathrm{M}^{3}$ SUBSEQUENTLY WAS DROPPEO FROM CONSIDERATION. IT IS INCLUDED HERE FOR COMPARATIVE PURPOSES ONLY.

SOURCE: INFL.ATIONARY IMPACT STATEMENT OF THE COTTON DUST STANDARD, OSHA, 1978. 
and control. The main thrust of proposed legislation is to encourage industry to design, install, and operate machinery, equipment, and entire plants that produce lower noise levels. Lower noise levels should ensure prevention of hearing loss by workers and improve working conditions. According to the Department of Labor (DOL), the required use of earplugs by employees is a means of last resort and should be relied on only when engineered noise abatement procedures have failed. DOL states that unacceptable noise levels must be reduced by redesigned, modified, or otherwise changed machinery and by changes in the architectural designs of buildings.

OSHA favors a standard that does not permit noise to exceed 90 decibels $A$-weighted sound level (dBA) for 8 hours of exposure. The OsHA standard also states that the threshold limit value of noise should not exceed a maximum 15 minutes exposure to a constant noise level of $115 \mathrm{dBA}$. Some textile activities will have problems meeting a 90 dBA requirement. Weaving has the highest average noise level of any textile operation (see Table 5-3). To varying degrees, twisting, spinning, combing, and warping may also be impacted by OSHA noise regulations. On the other hand, the Environmental Protection Agency has recommended that OSHA reduce the noise ceiling to $85 \mathrm{dBA}$. Under these more stringent conditions, six additional textile activities (roving, spooling, drawing, dyeing, carding, and picking) will be affected to varying degrees.

OSHA published a proposed standard of $90 \mathrm{dBA}$ on octoher 24, 1974. It intends to mathtain this ceiling until turther evaluation indirates that a lower noise celling of $85 \mathrm{dBA}$ is necessary and would be practical to implement.

In a study entitled "Economir. Tmpart Analycio of Proposed Noise control Regulation" prepared fur OSHA, noise monitoring in all of U.S. industry is estimated to cost approximately $\$ 155$ million per year ( $\$ 20$ per production worker). Audiometric testing for all workers presently exposed, on a time-weighted basis, to noise levels above 85 dBA wi.l. cost approximately $\$ 86$ million per year, or $\$ 12$ per worker. Thus, the current proposed regulation will cost industry a total of $\$ 241$ million annually. 
TABLE 5-3

Typical Noise Levels in Textile plants

\begin{tabular}{|l|c|c|}
\hline AREA & $\begin{array}{c}\text { A.WEIGHTED } \\
\text { SOUND LEVEL RANGE } \\
\text { dBA }\end{array}$ & $\begin{array}{c}\text { AVERAGE } \\
\text { dBA }\end{array}$ \\
\hline WEAVING & & \\
TWISTING & $95-103$ & 99 \\
SPINNING & $92-97$ & 95 \\
COMBING & 92.93 & 92 \\
ROVING & $91-92$ & 91 \\
SPOOLING & $87-90$ & 89 \\
ORAWING & $86-88$ & 87 \\
DYEING & $86-88$ & 87 \\
CARDING & $85-86$ & 86 \\
PICKING & 82.87 & 85 \\
FINISHING & $76-87$ & 82 \\
WARPING & $81-82$ & 82 \\
SLASHING & $80-91$ & 81 \\
INSPECTION & $78-82$ & 80 \\
\hline
\end{tabular}

SOURCE: COOPER, W.D., AN INTRODUCTION

TO THE TEXTILE INOUSTRY OF THE

70'S, NORTH CAROLINA STATE

UNIVERSITY, SCHOOL OF TEXTILES,

1973. 
Meeting an $85 \mathrm{dBA}$ regulation solely by use of hearing protection would cost about $\$ 43$ million annually. If audiometric testing and monitoring were also required, the total annual cost would be $\$ 284$ million ( $\$ 241$ miliion plus $\$ 43$ million), or about $\$ 38$ per worker.

An $85 \mathrm{dBA}$ regulation achieved through engineering controls would require an incremental investment by the industrial sector of about $\$ 8$ billion dollars. That is, the additional investment necessary to move from full compliance with a 90 dBA standard to full compliance with an 85 aBA standard is $\$ 8$ billion. The $\$ 8$ billion capital cost is expected to decrease as the compliance period is extended. Applying a 3 percent per year cost reduction for 10- and 15-year compliance periods reduces capital costs by 18 and 25 percent, respectively. In additioil, the annual mnnitoring cost of $\$ 155$ million would continue; however; once an $85 \mathrm{dBA}$ regulation is fully implemented, audiometric testing would no longer be necessary. Thus, the $\$ 86$ million annual cost for testing would not be incurred after compliance is achieved and the annual cost per worker would be $\$ 108$ spread over 10 years and $\$ 73$ spread over 15 years.

Impacts of the standards on the textile mill products industry are significant. Assuming the 1977 level of 914,000 workers in the industry, results in the following anticipated costs for compliance with the proposed OSHA noise standards:

Noise Monitoring

Audiometric testing (Above 85 dBA)

- Worker Hearing protection ( $85 \mathrm{JBA})$
$\$ 18$ million per year

sil million per year

$\$ 5$ million per yoar

Achieving the 85 dBA regulation through engineering controls would cost the textile mi.l. I products industry about $\$ 99$ million per year over a 10 year compliance period or about $\$ 67$ million per year over a 15 year period.

The cost estilldtes for audiometric testing, noise monitoring, and heiring piutcction prugrams are based on actual costs incurred by firms that are presently carrying out such activities. The costs of achieving an 85 dBA level through engineering controls are based on data obtained in previous projects and in visits to a sampling of plants. 
The requirement that the industry spend large amounts of capital to comply with the OSHA noise regulations is considered a negative factor in the development of increased materials recovery. The capital requirements to implement recycling technology will directly compete with the already heavy demands for capital occasioned by the need to comply with existing OSHA regulations. Of course, in the long term there probably will be a cost payback to the industry due to a reduction in compensation claims and lost work time from noise-related causes. However, these costs are not readily quantifiable at this time.

5.1.4 Department of Commerce Is a Major Participant in Determining International Trade Policies in Textiles and Apparel

The Department of Commerce (DOC) plays a major role in formulating foreign trade policies that affect the textile industry. The committee for Implementation of Textile Agreements (CITA), established by Executive Order 11651 and chaired by DOC, is comprised of representatives of the Departments of State, Labor, and the Treasury. The Office of the Special Representative for Trade Negotiations is a nonvoting member. CITA is responsible for implementation of all bilateral textile agreements and the Multi-Fiber Agreement (MFA), which is an overall international agreement stating principles and agreements to be followed by all textile exporting and importing countries.

Separate and distinct from the bilateral and MFA negotiations are the Multilateral Trade Negotiations (MTN). These negotiations are conducted periodically between foreign countries with the aim of reducing tariff and nontariff (quota limitations) barriers to trade. The MTN negotiations typically cover a wide spectrum of commodities and products in addition to textiles but, historically, textiles have always been a major topic of discussion with respect to changing trade barriers. The MTN can be viewed as a national marketplace where nations trade off commodities in an attempt to place their countries in the most favorable trade position possible. 
The current MTN negotiations in Geneva offer a representative example. The United States appears to be willing to reduce textile tariffs on goods exported from Europe in exchange for some $\$ 3$ billion of new agricultural export opportunities in Europe. According to a new Congressional Budget office paper on the negotiations, there will be winners and losers as the trade agreements stand now. While some consumers and producers should benefit greatly from freer trade arrangements, "Some businesses will be forced to close and some workers will lose their jobs because of increased foreign competition," the report says.

Biggest potential U.S. industrial losers: textiles, footwear and other leather products, pottery, food utensils, steel products, radio, television, and jewelry. These industries are relatively labor-intensive or use simple, well-known technologies.

The winners: industries producing tobacco products, semiconductors, computing machines, office machines, mechanized measuring devices, electronic components, aircraft and aircraft equipment. These industries employ new or sophisticated technology. U.S. agriculture also stands to benefit, especially if American negotiators win reduction of nontariff barriers in Europe and Japan.

Lay-offs would be borne disproportionately by semiskilled and minority workers-an impact that would be especially noticeable in the textile industry, where minorities make up 23 percent of the labor force ard 65 vercent are women. Unless some provision is made for dislocated workers, the report says, Congress is not likely to approve the treaty. The present "adjustment program" is termed inadequate. It should be obvious that foreign trade in textiles is a complex issue that is sensitive to international politics and almost impossible to predict, especially to 1987 . However, a review of the recent foreign trade in textiles can be useful in drawing some general conclusions.

Table 5-4 presents data on the trade balance for each fiber for the period $1972-77$. The table, along with Figures 5-1 and 5-2, can be used in reaching several significant conclusions: 
TABLE 5-4

U.S. Foreign Trade in Textile Manufacture:

Fiber Equivalent Exports, Imports,

and Trade Balance by Fibers

$(1,000$ pounds $)$

\begin{tabular}{|c|c|c|c|c|c|c|c|c|c|c|c|c|}
\hline \multirow[b]{2}{*}{ YEAR } & \multicolumn{4}{|c|}{ EXPORTS } & \multicolumn{4}{|c|}{ IMPORTS } & \multicolumn{4}{|c|}{ TRADE BALANCE } \\
\hline & COTTON & WOOL & MAN-MAOE & TOTAL & COTTON & WOOL & MAN-MADE & TOTAL & COTTON $^{1}$ & wool ${ }^{\prime}$ & MAN-MADE' & TOTAL ${ }^{\prime}$ \\
\hline 1972 & 290,444 & 33,332 & 177584 & 501,360 & 610,703 & 95,377 & 480,453 & 1.186 .533 & 320,259 & 62,045 & 302,869 & 685.173 \\
\hline 1973 & 325,197 & 33,363 & 288.227 & 646,787 & 563.501 & 89,962 & 465,319 & 1.118 .782 & 238,304 & 56,599 & 177,092 & 471,995 \\
\hline 1974 & 392,493 & 25,975 & $39 Q, 734$ & 809,202 & 502.679 & 74.225 & 371,252 & 948.156 & 110,186 & 48,250 & $19.482^{2}$ & 138.954 \\
\hline 1975 & 353,663 & 21,386 & 322,388 & 697.437 & 501.252 & 68,422 & 400,376 & 970,050 & 147.589 & 47.036 & 77,988 & 272,613 \\
\hline 1976 & 413,154 & 15,082 & $35 \approx, 176$ & 780.412 & 708.601 & 98.579 & 479,487 & $1.286,667$ & 295.447 & 83,497 & 127,311 & 506,255 \\
\hline $1977^{3}$ & 369,762 & 13,038 & $36 i .026$ & 749,526 & 669.407 & 116.606 & 531,130 & 1.317 .143 & 299.945 & 103.568 & 164.104 & 567,617 \\
\hline
\end{tabular}

'Import trade 8alance.

${ }^{2}$ EXPORT TRADE BALANCE.

3 PRELIMINARY.

SOURCE: SUPPLEMENT FOR 1978 TO STATISTICS ON COTTON AND RELATED DATA BULLETIN NO. 535. U.S.D.A., MARCH 1978. 
FIGURE 5-1

Textile Foreign Trade Balance, 1972 to 1977

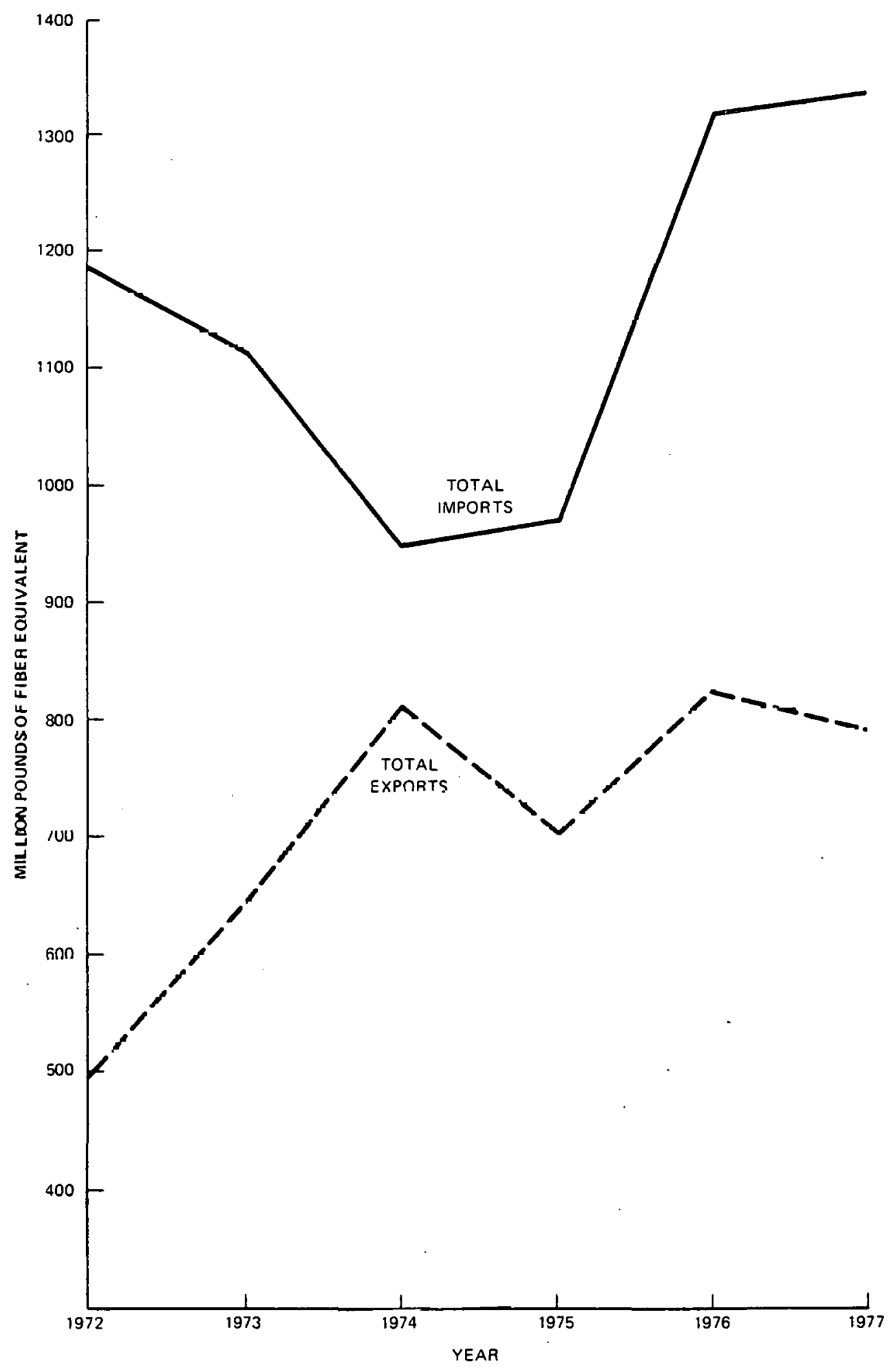


FIGURE 5-2

Textile Foreign Trade Balance By Fiber

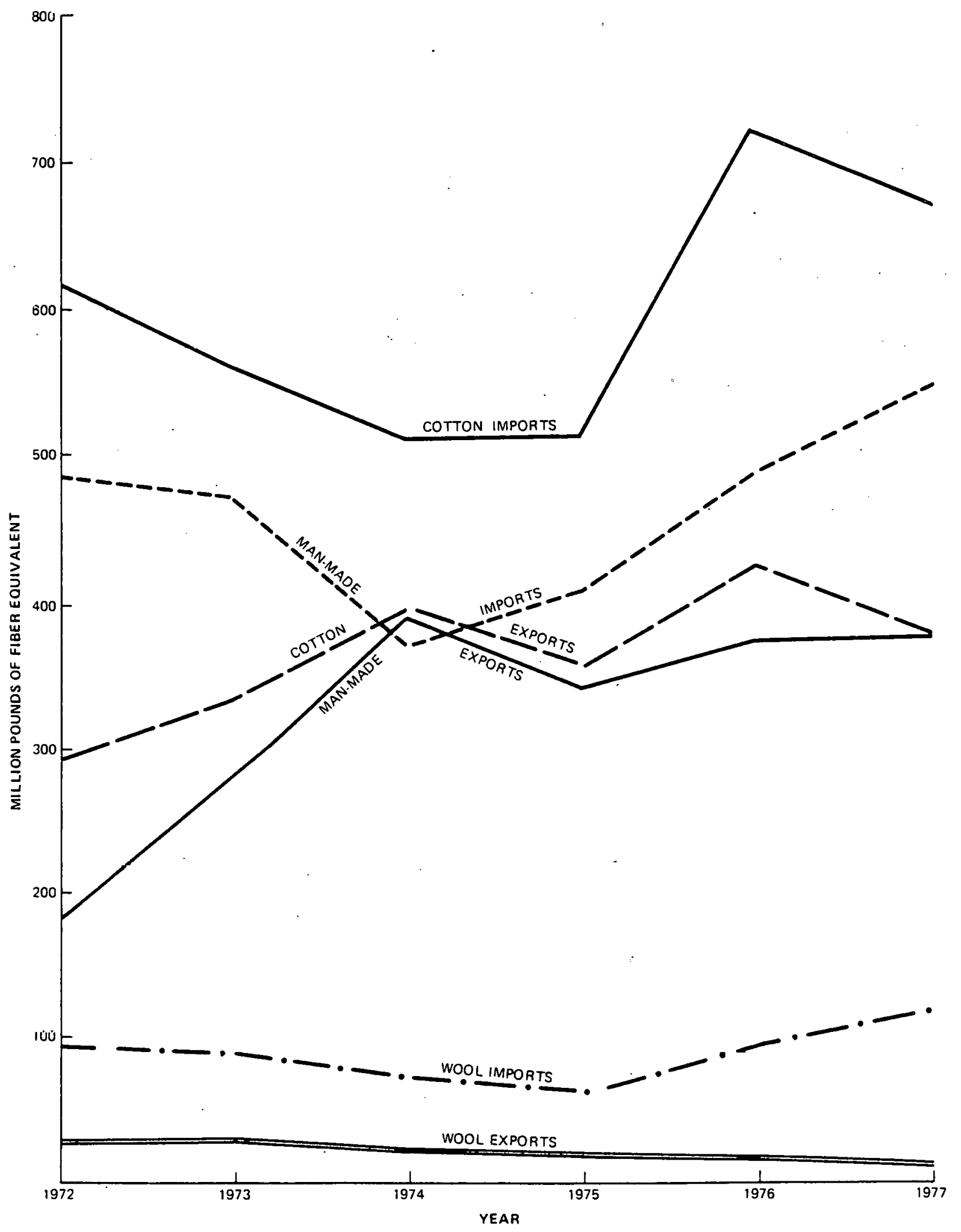


- The United States has demonstrated an import trade balance for total textile fibers since 1972. While the trade gap closed significantly in 1972-74, it has continued to widen since then to the point where the United States imported almost twice as much as it exported in 1977.

- Cotton imports represent the largest share of all textile fiber imports, followed by man-made fibers and wool imports, wool representing a relatively small share.

- Man-made fiber imports have steadily risen since 1974, while cotton import. levels are erratic over the same period.

- Only man-made fibers showed a slight export trade balance (in 1974), but since then an import trade balance has continued to widen.

- Cotton and man-made fiber export levels have demonstrated similar erratic trends over the last several years, appearing to reach equilibrium around the 380 million pound level.

- Wool exports have been in a gradual decline since 1972, reaching a low of about 13 million pounds in 1977.

The U.S. trade balance of textiles is not limited to yarns and wearing apparel. Waste materials are a significant portion of its foreign trade. Tables 5-5 and 5-6 present data on the raw wool content of U.S. exports and imports. Table 5-5 shows that the United States has exported relatively constant amounts of noils and wastes, even though its total wool exports dropped dramatically between 1972 and 1977. Table 5-6 and Figure 5-3 reveal that noils and wastes represent a large share (up to 30 percent) of total wool imports. This is a rather striking statistic, and there are similar statistics for other. fibers. Nronrding to DOC dald, the united States imported almost 7 million pounds of cotton wastes in 1976 and almost 5.5 million pounds in 1977. This does not include waste "rags," which are thought to be imported in substantial quantities thus making the waste exports to this country even higher. Much of this waste materials market could be diverted to domestic sources instead of 
TABLE 5-5

Raw Vool Content of United States Exports of Domestic Wool Manufactures ${ }^{1}$

$$
(1,000 \text { pounds) }
$$

\begin{tabular}{|c|c|c|c|c|c|c|c|c|c|c|c|c|}
\hline \multirow[b]{2}{*}{ YEAR } & \multirow{2}{*}{$\begin{array}{l}\text { TOPS AND } \\
\text { ADV ANCED } \\
\text { WOOL }\end{array}$} & \multirow[b]{2}{*}{ VARN } & \multirow{2}{*}{$\begin{array}{c}\text { FABRICS } \\
\text { WOVEN } \\
\text { AND } \\
\text { KNIT }\end{array}$} & \multirow{2}{*}{$\begin{array}{l}\text { WOOL } \\
\text { BLANKETS }\end{array}$} & \multicolumn{2}{|c|}{$\begin{array}{l}\text { WEARING } \\
\text { APPAREL }\end{array}$} & \multirow{2}{*}{$\begin{array}{c}\text { OTHER } \\
\text { MANUFACTURES }\end{array}$} & \multirow[b]{2}{*}{ FELTS } & \multirow[b]{2}{*}{ SUBTOTAL } & \multirow{2}{*}{$\begin{array}{c}\text { NOILS } \\
\text { AND } \\
\text { WASTES }\end{array}$} & \multirow{2}{*}{$\begin{array}{c}\text { CARPETS } \\
\text { AND } \\
\text { RUGS }\end{array}$} & \multirow[b]{2}{*}{ TOTAL } \\
\hline & & & & & KNIT & $\begin{array}{l}\text { OTHER } \\
\text { THAN } \\
\text { KNIT }{ }^{2}\end{array}$ & & & & & & \\
\hline 1972 & 25,548 & 563 & 599 & 88 & 434 & 917 & 910 & 455 & 29.514 & 2.753 & 1,065 & 33.332 \\
\hline 1973 & 23,073 & 395 & 1.069 & 217 & 917 & 1.427 & 1,248 & 432 & 28,778 & 2,601 & 1,984 & 33,363 \\
\hline 1974 & 13,314 & 550 & 924 & 314 & 944 & 2.470 & 1.592 & 384 & 20.492 & 2,980 & $.2,503$ & 25,975 \\
\hline 1975 & 11.010 & 813 & 1,293 & 530 & 428 & 1.717 & 1,271 & 257 & 17.319 & 2,186 & 1,880 & 21.386 \\
\hline 1976 & 4.959 & 768 & 954 & 673 & 507 & 1.655 & 1.516 & 511 & 11,543 & 1.277 & 2,262 & 15,082 \\
\hline $1977^{4}$ & 1,702 & 1.474 & 878 & 704 & 586 & 1.829 & 2,054 & 234 & 9.461 & 1.591 & 1,986 & 13.038 \\
\hline
\end{tabular}

1 INCLUDES MANUFACTURES OF MOHA:R, ALPACA, AND OTHER WOOL-LIKE SPECIALITY HAIR.

2 INCLUDES MEN'S AND BOYS' SUITS, PFNTS, OVERCOATS; WOMEN'S AND CHILDREN'S SUITS, DRESSES, ENSEMR'.ES, AND WOOL FELT HATS.

${ }^{3}$ NOT INCLUDINE RAGS.

${ }^{4}$ PRELIMINAARY. 
TABLE $5-6$

Raw hool Content of United States imports for Consumption of Wool Manufactures ${ }^{1}$

$(1,000$ pounds $)$

\begin{tabular}{|c|c|c|c|c|c|c|}
\hline \multirow[b]{2}{*}{ YEAR } & \multirow[b]{2}{*}{$\begin{array}{l}\text { TOPS AND } \\
\text { ADVARCE[ WOOL }\end{array}$} & \multirow[b]{2}{*}{ YARNS } & \multirow[b]{2}{*}{$\begin{array}{l}\text { WOVEN } \\
\text { FABRICS }^{2}\end{array}$} & \multirow[b]{2}{*}{$\begin{array}{l}\text { WOOL } \\
\text { BLANKETS }\end{array}$} & \multicolumn{2}{|c|}{ WEARING APPAREL } \\
\hline & & & & & KNIT & OTHER THAN KNIT \\
\hline 1972 & 425 & 6.312 & 8,765 & 707 & 19,998 & 11,247 \\
\hline 1973 & 325 & 4,931 & 12,473 & 386 & 15,026 & 12,394 \\
\hline 1974 & 520 & 5,395 & 9,251 & 370 & 12.735 & 11,149 \\
\hline 1975 & 338 & 4,121 & 8,360 & 416 & 12.237 & 10,677 \\
\hline 1976 & 403 & 5,375 & 12,210 & 380 & 18902 & 14,071 \\
\hline \multirow[t]{2}{*}{$1977^{7}$} & 842 & 5,802 & 18,651 & 405 & 25.866 & 18,263 \\
\hline & $\begin{array}{c}\text { OTHER } \\
\text { MANUFACTURES }\end{array}$ & SUBTOTAL & NOILS & WASTES 6 & $\begin{array}{l}\text { CARPETS } \\
\text { AND RUGS }\end{array}$ & TOTAL \\
\hline 1972 & $\Xi 272$ & 50.726 & 21.773 & 10.589 & 12,289 & 95,377 \\
\hline 1973 & 2.136 & 47.671 & 17,892 & 10.801 & 13,598 & 89,962 \\
\hline 1974 & 1,348 & 40.768 & 13,374 & 7.592 & 12,491 & 74,225 \\
\hline 1975 & 1.063 & 37.212 & 13,497 & 6,299 & 11,710 & 68,422 \\
\hline 1976 & 1.331 & 52.672 & 21,341 & 10,507 & 14,059 & 98,579 \\
\hline $1977^{\prime}$ & 1.224 & 71.053 & 9,425 & 11,290 & 14,838 & 116,606 \\
\hline
\end{tabular}

1 INCLUDES MIANUFACTURES OF MGHAIF, ALPACA, AND OTHER WOOL.LIKE SPECIALTY HAIR.

2 INCLUDES PILE FABRICS AND VANUFACTURES, TAPESTRY AND UPHOLSTERY GCIODS, PRESS. AND BILLIARD CLOTHES.

3 INCLUDES CARRIAGE AND AUTOMDBILE ROBES, STEAMER RUGS, ETC.

${ }^{4}$ INCLUDES LACES, LACE ARTICLES, VEILS AND VEILINGS, NETS AND NETTINGS, W'HEN REPORTED IN POUNDS.

${ }^{5}$ INCLUDES KNIT FABRICS IN THE PIECE AND M SCELLANEOUS MANUFACTURES NDT ELSEWHERE SPECIFIEJ.

$6_{\text {NOT INCLUDING FAGS. }}$

7 PRELIMIMAARY. 


\section{FIGURE 5-3}

Wool Waste Imports vs. Total Wool Imports, 1972 to 1977

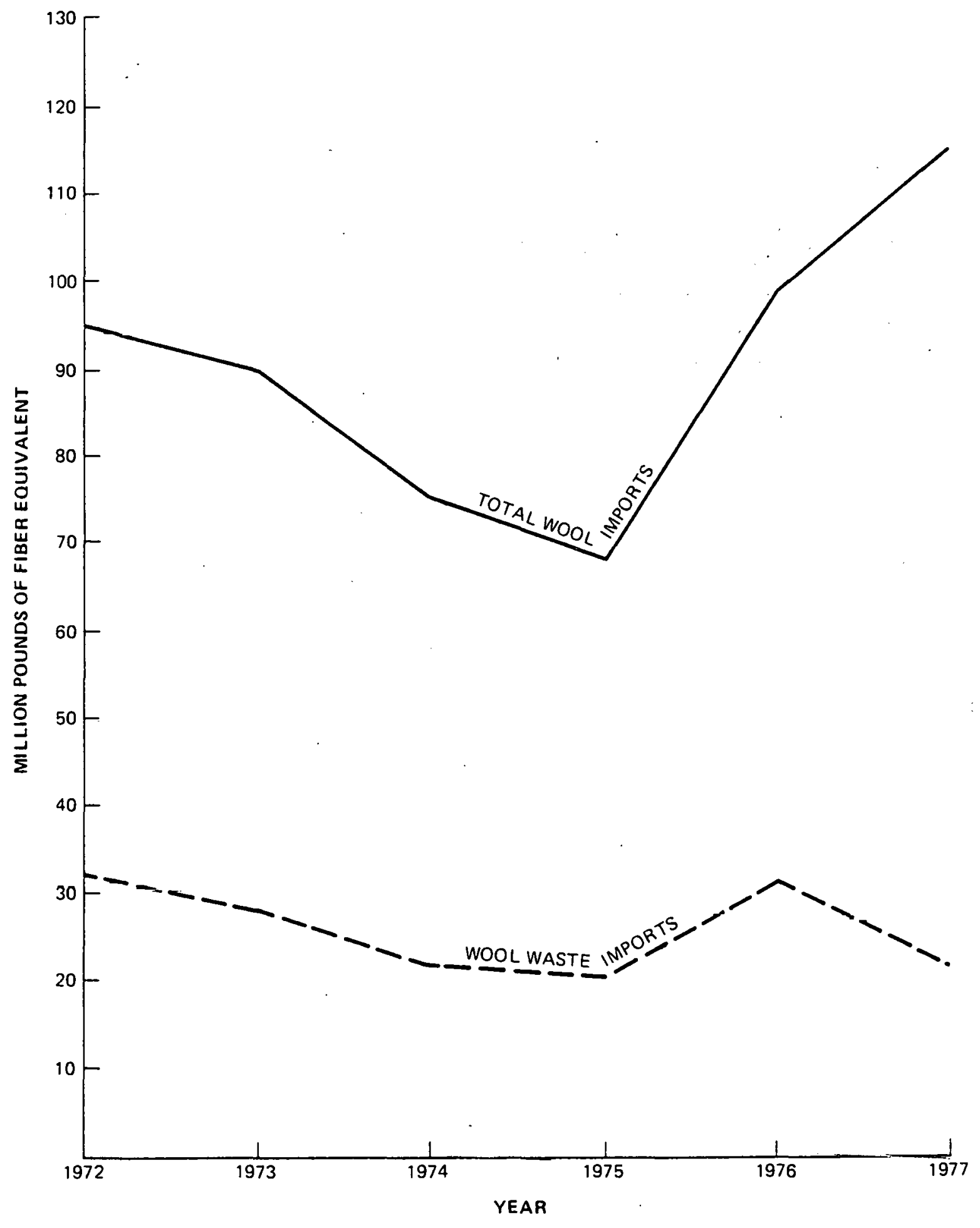


being imported from foreign manufacturers. Reducing or perhaps eliminating textile waste imports should serve as an impetus to increased waste materials recovery in the United States.

\subsubsection{Treasury Department}

Two Treasury Department regulations that affect the importing of textile goods into the United States can have a positive impact on the use of recovered materials. The two are the Antidumping Act of 1921 and the Tariff Act of 1932. They are discussed in the following paragraphs.

5.1.5.1 Rules and Regulations Under the Antidumping

The purpose of the Antidumping Act is to protect domestic industries from losses due to imports being sold at less than fair value. In other words, the price of a commodity in the home market of the foreign country is compared with the price for the same commodity sold as an export to the United States. If investigation by the U.S. Customs Service indicates that commodities are being "dumped" in this country, appropriate measures are taken, such as placing additional tariffs or bounties on the product to allow domestic producers to be more competitive. Petitions to investigate dumping by foreign manufacturers can be initiated by any domestic producer. These regulations have a positive influence on the textile industry, because their objective is to foster falr trade and protect domestic manufacturers.

5.1.5.2 Rules and Regulations Under the Tariff Act, 1932

Under this act, the U.S. Customs Service may investigate whether foreign governments are giving benefits (bounties or grants) to thoir domeslic mantiacturers who are exporting products to the United States. This is known as a "Countervailing Duty Determination." The objective again is to protect American domestic manufacturcra from losses stemming from the unfair competitive advantage a foreign manufacturer can gain when he is subsidized by a foreign government.

The benefits considered to be bountics or grants include the following: 
- Income tax exemptions on certain exportrelated income

- Preferential financing for exports

- Export rebates

- Certain economic development incentives

- Drawback of duty on industrial equipment

- Export risk insurance at low rates.

In the textile sector, there is an average of 10 to 20

petitions filed each year for countervailing duty determinations and antidumping determinations. Half of these result in the conclusion that the foreign countries have not given benefits to their domestic manufacturers. For the other cases, additional duties are imposed by the United States on the foreign textile imports to bring their price up to fair value.

5.1.6 Consumer Product Safety Commission Administers The Flammable Fabrics Act as Amended and Revised, 1967

Since May 1973 the Consumer Product Safety Commission (CPSC) has had responsibility for administering the Flammable Fabrics Act. This responsibility includes the authority to set flammability standards and to inform the public of hazards associated with flammable fabrics. At present there are seven sets of standards implementing the act:

\section{Standard for Flammability of clothing Textiles} (CS 191-53)

Standard for Flammability of Children's

Sleepwear: sizes $0-6 x$ (FF 3-71)

Standard for the Surface Flammability of

Carpets and Rugs (FF 1-70)

- Standard for the Surface Flammability of Small Carpets and Rugs (FF 2-70)

- Standard for the Flammability of Children's Sleepwear: sizes 7-14 (FF 5-74) 


\section{- Standard for the Flammability of Mattresses and Mattress Pads (FF 4-72) \\ - Draft Standard on Upholstered Furniture Flammability.}

Flammability testing carried on by the CPSC consists of exposing samples of these textile products to a flame for 1 second or, in the case of carpets, exposing them to a burning tablet to simulate a small ignition source such as a match. If the burn rate does not exceed certain. limits, the sample is considered to meet the standards.

These standards do not appear to be presenting any technical or financial problem to the induetry at largc. Discussions with textile technologists at CPSC indicate that the use of recycled fibers should not make it any more difficult to meet the flammability standards.

Of particular note is the draft standard on upholstered furniture. Such furniture does use a significant amount of batting and filling material. Like the standards in other areas, the standard for upholstered furniture is a performance standard rather than a design standard. It allows the industry to choose the filling materials and allows for the use of new and better materials as they become available. As long as the furniture meets the required cigarette ignition resistance, a manufacturer may use any combination of fabrics, chemical treatments, finishing techniques, or filling materials that he feels is suitable. With regard to filling materials, the industry prefers to chemically treat cotton batting with boric acid or to use 100 percent polyester fiber waste. Previous reports stated that urethane foam was more competitive and would reduce the market for textile waste materials as filling, but these reports have not been substantiated. On balance, it can be stated that the flammability standards administered by CPSC have neither a positive nor a negative influence on the increased use of recovered material and are therefore classified as neutral.

\subsubsection{Department of Defonsc Establishce Spccifications on Military Clothing}

Since the Department of Defense (DOD) is a large consumer of textile products, principally in fabrics for military clothing, its policies on the use of recycled fibers were investigated. Officials at the Navy Clothing and Textile 
Research Facility stated that specifications are published for each type of fabric used in the military. These specifications pertain to fiber types and fabric characteristics. These characteristics are measured against performance specifications, a list of which is given in Table 5-7.

The use of recycled fibers or waste materials is specifically addressed in only one of the specification documents, the "Wool Cloth" specification. In this case, the use of "noils, laps, or any other wool manufacturing by-product is prohibited" (MIL-C-16290G SA, June 17, 1971). Clearly, this DOD policy discourages further materials recovery in the textile mill products industry, at least with respect to wool products.

With regard to other fabrics, the DOD position is that as long as the performance specificaitons shown in Table 5-7 are met, the use of recycled fibers or waste materials is permitted. However, many senior ranking DOD personnel hold that there is already too much variation in the weave, color, and texture of military uniforms and that specifications should be made more rigid and tolerances narrowed. Uniformity of appearance is very critical to the military, and they test. their fabrics before accepting them. In addition, DOD must follow federal laws regarding textiles (e.g. the Wool Products Labeling Act and the Textile Fibers Identification Act). DOD's specifications incorporate the provisions of these acts.

Practically speaking, the DOD policies do not encourage the use of recycled fibers or waste materials. In the case of wool fabrics, they clearly do work against the use of waste products. Even if increased materials recovery were implemented in these areas of the textile mill products industry that produce military fabric, DOD would not be likely to reduce its performance requirements and could in fact make them even more stringent.

\section{1 .8 Department of Energy}

The National Energy Act was passed by the Congress on October 15, 1978. The art. is composed of five bills, several provisions of which could affect individual plants substantially. On a total industry basis and specifically with regard to materials recovery, the National Energy Act is viewed as having no substantial effect. The materials recovery targets provision of the act, which is the subject of this report, is considered to have a positive effect on the increased use of waste materials. 
TABLE 5-7

Typical Fabric Characteristics for Thich performance Specifications Are Established

Weight
Yarns per inch (cm)
Tarp
Filing
Ereaking strength
Varp
Filling
Tear strength
Taro
Filing
Flex stiffness
Tarp
Filing

Air permeability

\author{
Weave \\ Colorfastness to: \\ Laundering \\ Crocking \\ Persoiration \\ Dry cleaning \\ Light \\ r.Tater \\ Permanence of finish \\ Air permeability \\ Thickness \\ Shrinkage \\ Heat treating \\ Monfibrous materials \\ $\mathrm{pH}$ \\ Sean slippage
}


5.1.8.1 Power Plant and Industrial Fuel Use Act of 1978

The Fuel Use Act prohibits new industrial boilers with a fuel heat input rate of 100 million Btu's per hour or greater from using oil or natural gas unless an exemption is granted. The exemption would need to be based on the fact that the use of coal is precluded by environmental regulations, cost, site limitations or other justifiable reasons. For existing industrial boilers, DOE may order coal capable units not to burn oil or gas and to shift to coal. These provisions could negatively influence some textile mills because natural gas and fuel oil account for 50 percent of the total industry energy use while coal represents seven percent.

Since the oil embargo, a few large boilers in textile mills have been reconverted to coal. The rising cost of fuel oil and natural gas plus the relaxing of some state air pollution regulations encouraged this change. These conversions, however, are limited, and there appears to be no particular rush to reconvert to coal. Within the plants that use coal, the use is generally limited to the very largest boilers, those boilers delivering at least 150,000 lbs of steam per hour. Thus, only one large boiler at each plant may use coal, while smaller boilers remain on fuel oil or natural gas. Sampled companies indicate that large boilers will be converted to coal only during routine replacement and not in a "crash program."

Conversion to coal will introduce other problems for affected textile mills: costly electrostatic precipitators will be required to meet emission standards; larger fuei storage facilities and materials handing mechanisms will be required; and disposal problems will become more significant. One industry official noted that an item which would help accelerate the fuel switching would be the availability of a package-type coal burning boiler.

In the event supplies of natural gas are curtailed to textile mills, many mills have standby supplies of propane to which they can convert. Propane, at three times the cost of natural gas, is reportedly the preferred fuel to substitute for natural gas when the latter is not available. Recently, the interest in natural gas led at least one textile company to pursue, on a preliminary basis, exploration for natural gas wells, which would allow the firm to ship gas through interstate pipelines at intrastate rates. 
In summary, it appears that the textile industry will be able to use fuels in about the same proportion as presently. There will probably be a few large integrated corporations which will have to bear the inconvenience and costs of converting to coal but on an industry basis the overall influence of the coal conversion provisions of the National Energy Act is considered to be neutral.

\subsubsection{Natural Gas Policy Act}

As large consumers of natural gas, some textile mills could be negatively influenced by the pricing provisions of this act. Under the act, interstate pipelines and distribution companies served by interstate pipelines must pass along the higher costs of new, high-cost, and imported natural gas to their large industrial customers who use gas for boiler fuel to generate steam or electricity. Inner incremental pricirg, inäustrial boiler fuel users will bear the increment of gas costs above $\$ 1.48$ per million Btu (as of March 1978, adjusted each month for inflation), until the price to these users rises to the cost of fuel oil in the region. Only when the rates of all industrial boiler fuel customers reach this level will residential and small commercial users have to bear a portion of the higher gas costs. The act exempts (on an interim basis) small industrial boiler fuel facilities (less than 300,000 cubic feet of gas per day). Assuming that many of the smaller textile mills will fall under this exemption, the increased costs should be felt by only the large producers. Therefore, on a total industry basis, the effects of the Natural cas folicy Act are considered to be neutral.

\subsubsection{Energy Tax not}

There are two provisions relative to energy tax credits under this act which effert the tcxtile industry. The first is an additional ten percent investment tax credit for the installation of equipment for the recycling of waste materials. This clearly is positive influence on the further development of materials recovery in the textile industry. The second provision is a nerative factor in that it restricts investment tax credits. The restriction is meant as a penalty for those textile firms which construct new oil or 
gas fired boilèrs. Such facilities will not be entitled to the current investment tax credit and will be limited to straight-line depreciation. The normal exceptions apply if it can be shown that a new coal facility is precluded by environmental requirements. Assuming that the number of new textile mills constructed in the near future is limited, these provisions are not considered to have either a positive or negative effect on the industry as a whole.

\subsubsection{National Energy Conservation Policy Act}

Title III of this act requires DOE to establish a program to promote increased energy effiency by industry. Requirements of the program include identification of the ten most energy-intensive industry groups and the most energy-consumptive corporations in each such group. The program also provides for the setting of voluntary industrial energy efficiency improvement targets and requires reporting procedures to be followed so that DOE can monitor energy conservation progress. The textile mill products industry was ranked as the tenth most energy-intensive industry and, therefore, the largest textile firms (using one trilition Btu's of energy or more) are presently reporting their energy use to DOE. The effect of these provisions on the textile industry is neutral in that the industry had a proven record of energy conservation and voluntary reporting through their trade associations even before the NECPA was effective. Therefore, these new requirements will not cause any substantial difficulties or problems for the industry relative to materials recovery.

\section{1 .9 Summary of Governmental Impacts}

Table 5-8 briefly summarizes the material in this section. It lists the federal departments, agencies, and commissions whose policies affect the textile mill products industry and in each case indicates whether or not those policies encourage materials recovery.

This section has discussed the effects of major government regulations on the textile mill products industry. Changes that could encourage materials recovery are discussed in the following section. 
TABLE 5-8

Summary of Government Influence on the Textile Industry

\begin{tabular}{|c|c|c|c|c|c|}
\hline \multirow{2}{*}{ AGENCY/DEPARTMENT } & \multirow{2}{*}{ REGULATION, POLICY, RULING } & \multicolumn{3}{|c|}{$\begin{array}{l}\text { PAINCIPAL FIBERS } \\
\text { AFFECTED }\end{array}$} & \multirow{2}{*}{$\begin{array}{l}\text { EFFECT ON } \\
\text { MATERIALS } \\
\text { RECOVERY }\end{array}$} \\
\hline & & COTTON & WOOL & MAN-MADE & \\
\hline $\begin{array}{l}\text { ENVIRONMENTAL PFOTECTION } \\
\text { AGENCY }\end{array}$ & $\begin{array}{l}\text { - RULES ON HAZARDOUS WASTE MANAGEMENT } \\
\text { - RULES ON EFFLUENT GUIDELINES, PRETREAT. } \\
\text { MENT STANDAROS, ANO STANDAROS OF } \\
\text { PERFORMANCE }\end{array}$ & $\begin{array}{l}x \\
x\end{array}$ & $\begin{array}{l}x \\
x\end{array}$ & $\begin{array}{l}x \\
x\end{array}$ & $\begin{array}{l}\text { NEGATIVE } \\
\text { NEOATIVE }\end{array}$ \\
\hline FEDERAL TRADE COMMISSION & $\begin{array}{l}\text { - RULES AND REGULATIONS UNDER THE } \\
\text { WOOL PROOUCTS LABELING ACT OF } 1939 \\
\text { - RULES ANO REGULATIONS UNDER THE } \\
\text { TEXTILE FIBER PROOUCTS IOENTIFICA. } \\
\text { TION ACT, } 1958\end{array}$ & $x$ & $x$ & $x$ & $\begin{array}{l}\text { NEGATIVE } \\
\text { NEUTRAL }\end{array}$ \\
\hline DEPARTMENT OF LABOR & $\begin{array}{l}\text { - OSHA COTTON DUST STANDARD } \\
\text { - OSHA NOISE STANDARD } \\
\text { OSHA TOXIC AND HAZARDOUS SUBSTANCE } \\
\text { EXPOSURE STANDARD }\end{array}$ & $\begin{array}{l}x \\
x \\
x\end{array}$ & $\begin{array}{l}x \\
x\end{array}$ & $\begin{array}{l}x \\
x\end{array}$ & $\begin{array}{l}\text { NEGATIVE } \\
\text { NEGATIVE } \\
\text { NEGATIVE }\end{array}$ \\
\hline DEPARTMENT OF COMMERCE & $\begin{array}{l}\text { - GENERAL AGREEMENTS ON TARIFFS AND } \\
\text { TRADE (GATT) } \\
\text { - ARRANGEMENT REGARDING INTERNATIONAL } \\
\text { TRAOE IN TEXTILES (MFA) }\end{array}$ & $\begin{array}{l}x \\
x\end{array}$ & $\begin{array}{l}x \\
x\end{array}$ & $\begin{array}{l}x \\
x\end{array}$ & $\begin{array}{l}\text { NEGATIVE } \\
\text { NEGATIVE }\end{array}$ \\
\hline DEPARTMENT OF TREASUAY & $\begin{array}{l}\text { - RULES AND REGULATIONS UNDFR THF } \\
\text { ANTIDUMPING ACT, } 1921 \\
\text { - RULES ANO REGULATIONS UNDER THE } \\
\text { TARIFF ACT, } 1930\end{array}$ & $\begin{array}{l}x \\
x\end{array}$ & $\begin{array}{l}x \\
x\end{array}$ & $\begin{array}{l}x \\
x\end{array}$ & $\begin{array}{l}\text { HUSITIVE } \\
\text { POSITIVE }\end{array}$ \\
\hline $\begin{array}{l}\text { CONSUMER PRODUCT SAFETY } \\
\text { COMMISSION }\end{array}$ & $\begin{array}{l}\text { - STANDAROS UNOER THE FLAMMABLE } \\
\text { FABRICS AC.T, 1953 }\end{array}$ & $x$ & $x$ & $x$ & NEUTRAL \\
\hline DEPAHTMENT OF DEFENSE & $\begin{array}{l}\text { - SPECIFICATIONS AND REQUIREMENTS FOR } \\
\text { MILITARY CLOTHING }\end{array}$ & $x$ & $x$ & $x$ & NÉGAIIVE \\
\hline DEPARTMENT OF ENERGY & $\begin{array}{l}\text { - POWER PLANT AND INOUSTRIAL FUEL USE ACT } \\
\text { - NAIU URAL CIAE POLICY ACT } \\
\text { - ENLKLYY TAXACT } \\
\text { - NATIONAL ENERG Y CONSERVATION POLICY ACT }\end{array}$ & $\begin{array}{l}x \\
x \\
x \\
x\end{array}$ & $\begin{array}{l}x \\
x \\
x\end{array}$ & $\begin{array}{l}x \\
x \\
x \\
x\end{array}$ & $\begin{array}{l}\text { NEUTRAL } \\
\text { NEUTRAL } \\
\text { NEUTRAL } \\
\text { NEUTRAL }\end{array}$ \\
\hline
\end{tabular}


This section discusses the changes or modifications to existing governmental policies that could encourage the use of recovered materials. Of course, government policy is only one aspect of the situation, and changes within the industry itself would also have to occur. Some of these changes noted below have already been attempted and were unsuccessful.

5.2 .1

EPA Rules and Regulations on Hazardous waste Management, Effluent Guidelines, and Pretreatment Standards

The EPA should consider setting up grants or subsidies to help support the installation of pollution control equipment for industries that practice materials recovery or reuse of waste material. This would help the industry in its increasing need for capital and would encourage the use of materials recovery technology.

5.2 .2

FTC Rules and Regulations Under the wool Products Labeling Act

Investigations should continue on the need to repeal or amend those provisions of the act that discriminate against the use of reused or reprocessed fibers. Perhaps a better definition of wool quality could be developed to include fiber length, strength, and color, rather than classifying fibers by origin or history. This would serve to increase consumer acceptance of secondary wool products and provide an impetus to the resurgence of the wool reprocessing industry in the United States.

\subsubsection{OSHA Cotton Dust Standard}

Increasing the exposure limit from $0.2 \mathrm{mg} / \mathrm{m}^{3}$ to $0.5 \mathrm{mg} / \mathrm{m}^{3}$ would significantly reduce the capital required by the industry to meet the cotton dust stanaard. Total installed costs would drop from about $\$ 2.5$ billion to $\$ 255$ miliion and total annualized costs would go from about $\$ 695$ million to $\$ 83$ million. OSHA has considered this issuc several times. 


\section{$5.2 .4 \quad$ OSHA Noise Standard}

Complying rith the OSHA 85 decibel noise stanciard using engineering controls rather than hearing protection cevices oill olace ouite a strain on available capital in the textile industry. The stancards are effectively in place. and the only feasible policy change that could lessen their inpact would be to lengthen the compliance perioc, thus spreading the costs out over tine. Iittle can be cone to lessen the impact of this act except substantially increasing the permissible noise levels; and that apoears unlikely in light of the previous stanci taken by OSHD.

\subsubsection{Department of Conumerce Policy changes}

Action should be taken to reverse the escalating import trade balance for textiles, including wastes. Increased U.S. textile export levels should be pursued, and increased tariffs on imported textile goods should be implemented. of course these steps cannot be done independently, and many other considerations of international trade need to be evaluated before these actions are implemented. Specifically, with regard to waste materials, steps should be taken to encourage the use of domestic wastes to supply the markets that are currently being served by wastes from foreign manufacturers.

\subsubsection{Department of Defense Policy Changes}

Modifications to current government procurement policy should be considered. The policy could be changed to require or encourage the use of secondary materials in military clothing without sacrificing adherence to performance specifications. Efforts should be increased to eliminate the prohibitions against the use of reused fibers in military textiles.

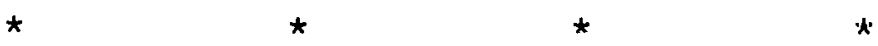

This chapter has described the governmental regulatory environment in which the textile mill products industry operates and has outlined the impact of government actions on the use of recovered materials. In addition, suggestions have been made for modifying existing regulations in order to enhance the use of recovered materials. Current levels of recycling in the textile mill products industry are discussed in the next chapter. 
6. CURRENT USE OF RECOVERED MATERIALS IN THE TEXTILE MILL PRODUCTS INDUSTRY

One indication of the importance of recovered materials and by-products in the U.S. textile mill products industry (SIC 22) is the fact that one subsector of the industry (SIC 2294) is currently given over to waste products. However, the use of primary or secondary waste in the fabrication of first tier textile products is limited because there is no known or anticipated technology for processing either. The use of secondary waste is minimal, but the small amount used, as well as most primary textile waste, is consumed by the second tier textile industries (furniture padding, nonwovens, etc.). A small amount of recycling of textile fibers is done in foreign countries; however, the resulting products are unacceptable for the U.S. market. These factors are discussed in the sections that follow.

6.1 MOST U.S. TEXTILE MILL WASTE IS CURRENTLY RECYCLED, BUT MAJOR SHIFTS IN WASTE GENERATION AND USE ARE ANTICIPATED

Given its low profit margin, the textile mill products industry requires mills to use input materials to their fullest. One way of meeting this requirement and, consequently, reducing waste is to choose fibers which most efficiently provide the characteristics demanded by customers. For example, a mill producing fine-combed cotton yarn tries to purchase cottons with a high percentage of long fibers and with a minimum of short or waste fibers. This reduces waste, but even with a continuous material control program, waste can still be a significant part of the cost of any textile production operation.

Another way to reduce material costs is to reintroduce reworkable fibrous waste back into the process. In some instances, more than half of the waste generated in a plant is used in this manner. In the textile mill products industry this consists of the fibers, sliver, and roving mill-ends that have had no appreciable twist imparted to them. These wastes are generated through normal process operations and are not a regular output of the process. 
The textile mill products industry reduces the quantity (as well as the quality) of the generated primary waste through waste control programs. This is done by shifting waste from higher quality first tier mills to lower quality first tier mills (see Figure 6-1). This type of waste control is most often practiced within large and diversified textile companies, although some nonrelated mills also ship their primary waste directly to other first tier mills.

In order to study the use of recovered materials, the American Textile Manufacturers Institute (ATMI) surveyed those of its members that use more than 1 trillion Btu's of energy per year. Table 6-1 gives the results of the survcy. A flow diagram is shown in Figure 6-2. The survey covered installatione that accuunt fur 25 percent of all fibrous materials purchased by the industry and processed in its 7,000 plants.

The average textile mill that uses blended fibers generates primary waste that amounts to between 12 and 16 percent of the total fiber processed. However, after inter- and intra-mill waste utilization programs are carried out, these figures are reduced to about 7.5 percent. Of the 7.5 percent, 6.8 percent is shipped to reprocessors or to second tier operations of other companies, and about 0.7 percent, consisting of short, oily fibers and carpet trim waste is discarded in landfills.

If the survey results are extended to the entire industry, total waste leaving the first tier textile mills in 1978 is estimated to be between 800 million and 1 billion pounds. As indicated in the survey, most of this waste was reprocessed and used by second tier textile operations, with only about 0.7 percent (about 100 million pounds) not bcing used at all. In general, this unused material was discarded in landfills.

The discarded waste that goes unused is composed of very short fibers (generally less than 0.25 inches) that are contaminated with machine oil, the extremely short fibers from shearing operations (corduroy, toweling), and caspet trlim waste that has been structurally changed by the additiun of latex backings. The textile producers and waste dealers have not as yet found a method for processing these discarded fibers, although the possibility of burning some types as boiler fuel is being studied. Two textile companies are currently burning shearing waste in boilers to reclaim some of the heating 
ETCURE 6-1.

Flow of Waste within the

TEXTILE MILL PRODUCTS INDUSTRY

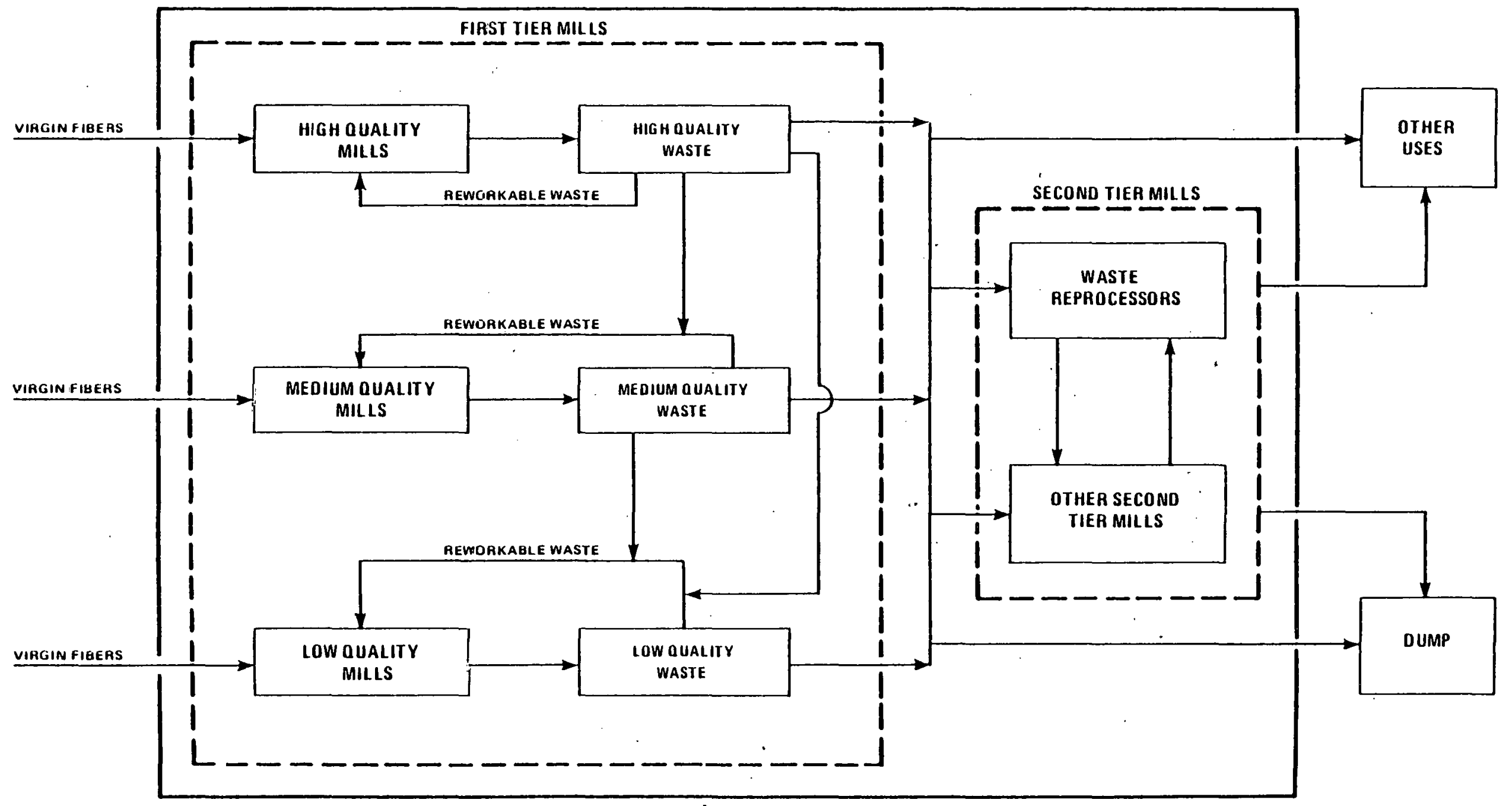


TABLE 6-1

Representative Yearly Materials Flow in the Textile Mill Products Industry*

\begin{tabular}{|c|c|c|}
\hline ITEMS REPORTED IN SURVEY & POUNDS & $\begin{array}{l}\text { PERLENT OF } \\
\text { SURVEY } \\
\text { TOTAL }\end{array}$ \\
\hline $\begin{array}{l}\text { - TOTAL PURCHASED INPUT OF FIBER, YARN AND } \\
\text { FABRIC } \\
\text { - TOTAL PURCHASED RECOVERED MATERIALS } \\
\text { - TOTAL RECOVERED MATERIALS SOLD AS BY. } \\
\text { PROOUCTS } \\
\text { - TOTAL RECOVERED MATERIALS TRANSFERRED } \\
\text { FROM PLANT TO PLANT (REWORKABLC WA3TE) } \\
\text { - TOTAL DISCARDED WASTE } \\
\text { (VEFY SMALL AMOUNT BURNED IN BOILERS) }\end{array}$ & $\begin{array}{r}3,662,860,351^{*} \\
33,823,076 \\
251,181,137 \\
16,321,154 \\
27,234,295\end{array}$ & $\begin{array}{r}100.0 \\
0.9 \\
6.8 \\
0.4 \\
0.7\end{array}$ \\
\hline
\end{tabular}

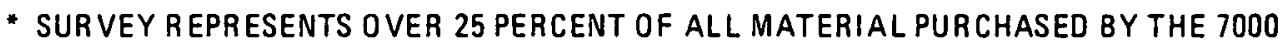
TEXTILE PLANTS IN THE INDUSTRY. THE SUR VEY WAS MADE IN 1979 BY THE AMERICAN TEXTILE MANUFACTURERS INSTITUTE. 
FIGURE 6-2

Typical waste Flow in the Textile Mill products Industry

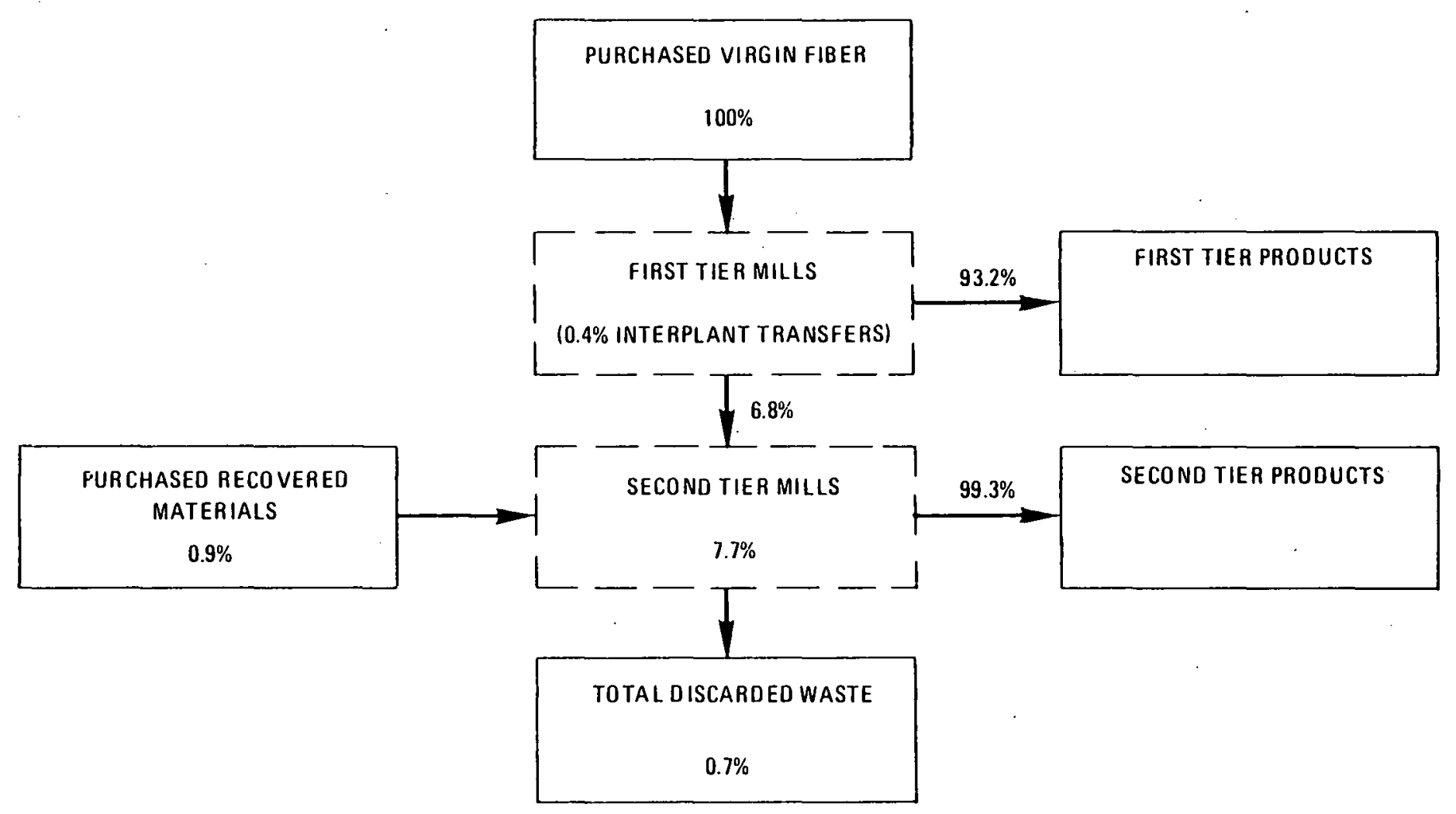


value. The Dalton (Georgia) Utility District is also evaluating the possibility of using carpet trim waste in a central boiler to produce steam, but similar trials have not been economically successful because of the low energy value of the waste material.

Only a small portion of the waste dumped throughout the industry is salable primary waste. The dumped waste is not used primarily for economic reasons, particularly transportation costs. If a mill is geographically distant from the potential uses of the waste, the low value of the waste is quickly offset by high transportation costs. Three factors, then, cause waste to be dumped:

- Low quality of the waste as in the case of short contaminated fibers

- Technological limitation on reprocessing, as in the case of carpet trimmings and other contaminated textiles

- High transportation and reprocessing costs.

Some waste produced by the first tier of the textile mill products industry is used directly by other industries that manufacture nontextile products. Generally these industries buy specific types of waste and are large enough to have their own reprocessing facilities. Examples include the paper industry and some sectors of the automotive industry. First level textile waste is also used by companies engaged in manufacturing, roofing, flooring, and by companies producing wiping sloths and other secondary fabrics.

The use of the waste is primarily based on economic factors such as the following:

- Price offered for the waste

- Cost and length of storage

- Tranoportatioir cust.

Noneconomic factors also help determine how the waste is used. These include considcritions sush as lhe following:

Long term contractual relationships with customers

- Established relationships with customers

- Restricted use of the particular waste. 
The volume of waste going from the first tier of the textile mill products industry to other industrial areas is difficult to determine. However, numerous interviews with leading textile industry experts indicate that the amount is less than 20 percent of the total waste generated.

Assuming that approximately 150 million pounds of generated waste are sold outside the textile mill products industry and 100 million pounds are discarded in landfills, the second tier textile mills consume an estimated 550 to 750 milition pounds of waste generated by the industry (see Table 6-2). This accounts for 4 to 6 percent of the total fibers consumed by the industry.

A large portion of the waste generated by first tier textile milis is reprocessed by the waste reprocessing sector of the textile mill products industry (SIC 2294). This sector is involved in the reprocessing, sorting, blending, and warehousing of waste. It obtains revenues primarily from the mechanical operations of reprocessing; however, the waste reprocessors also act as waste merchants or brokers between waste-producing mills and buyers of waste. This is usually done through "blind shipments," the waste being picked up from the mill by the shipper and transported to the buyer.

Because of the increased use of waste control in first tier mills and the expanded use of synthetic fibers (which result in less waste) the supply of waste has not grown at the rate of fiber production. The demand for pure waste or unblended waste far exceeds the amount generated by the mills. To fill this gap, reprocessors are relying increasingly on other sources (see Figure $6-3)$.

Since waste reprocessors are generally equipped to recycle only waste that is in an untwisted or unwnven state (roving, sliver, etc.) the shift to other sources of supply will require investment in more sophisticated machinery capable of reducing fabric or yarn into fiber. For most reprocessors, investment in new reprocessing equipment will be directly influenced by the pollution control requirements such as the OSHA cotton dust standard (see Chapter 5). Many reprocessors have already shifted their financial resources to meet federal requirements and have postponed investment in new equipment. There are also indications that some reprocessors may not be able to raise enough capital to meet the osHA standards. If they 
TABLE: 6-2

Use of Waste in the Textile Mill Products Industry

\begin{tabular}{|c|c|c|}
\hline $\begin{array}{l}\text { CONSUMING SECTOR } \\
\text { ITEM }\end{array}$ & $\begin{array}{l}\text { POUNDS } \\
\text { (MILLIONS) }\end{array}$ & $\begin{array}{c}\text { PERCENT OF } \\
\text { TOTAL } \\
\text { WASTE GENERATED }\end{array}$ \\
\hline - JISCARLIED TO LAND $=I L L$ & 100.000 & $13 \cdot 10$ \\
\hline - SOLE TO OUTSIDE IN OUSTRIAL SECTORS & 150,000 & $19-15$ \\
\hline $\begin{array}{l}\text { - TONSUUED BY THE SECOND TIER } \\
\text { TEXTILE MILL PRODUZTS INDUSTRY }\end{array}$ & $550,000 \cdot 750,000$ & $68 \cdot 75$ \\
\hline TOTAL WASTE GENERATED & $800,000 \cdot 1,000,000$ & $100 \cdot 100$ \\
\hline
\end{tabular}

NOTE: IT IS ESTIMAATED T HAT ABOUT 350,000,000 POUNDS OF THE TOTAL W.ASTE GEVERATE. J ARE REPROCESSED THROUGH WASTE DEALERS BEFJ.3E BEING UTILIZED BY THE SECOND TIER OF THE TEXTILE INDOUSTRY. 


\section{FIGURE 6-3}

Sources of Waste for the Second Tier of the Textile Mill Products Industry

SOURCES OF FIBROUS WASTE

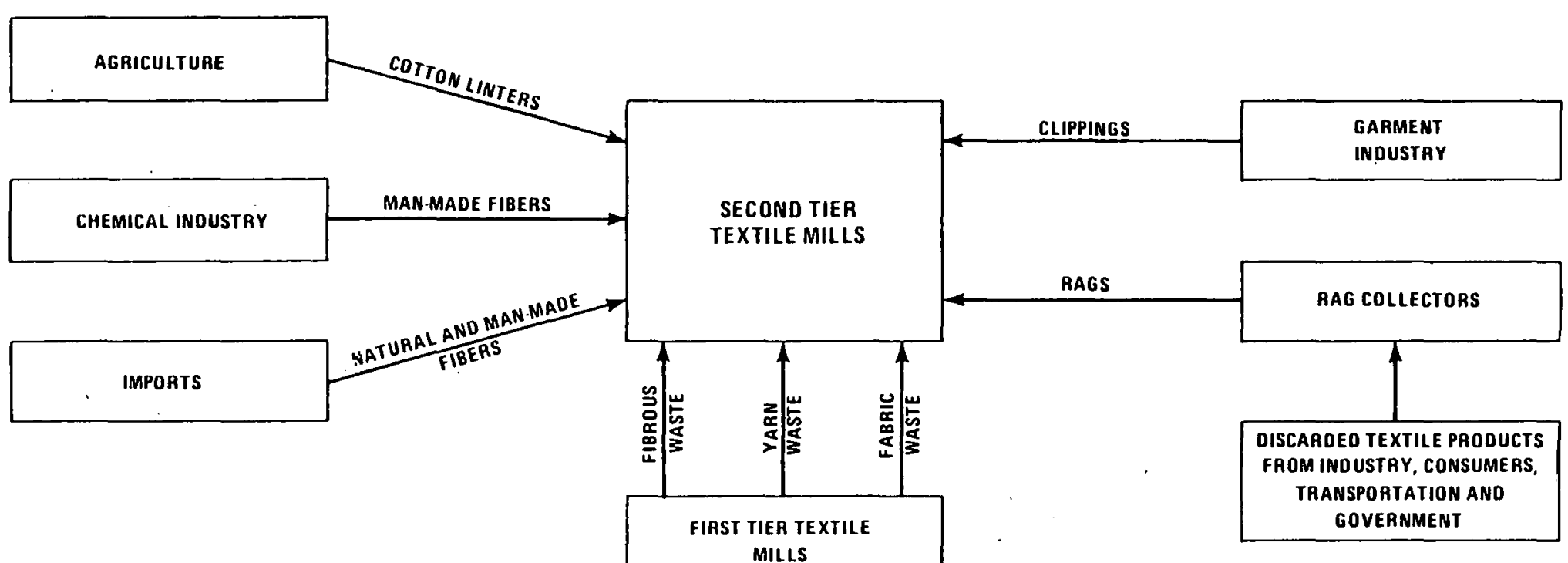


have limited financial resources, reprocessors must either cease reprocessing cotton waste and shift to man-made fiber reprocessing or stop operations altogether. The long-term effects of the shift in supply and of the new environmental controls are unmeasurable; however, several reprocessors indicated that the above-mentioned changes will certainly make waste less competitive, resulting in a shift in demand from recovered to virgin fibers.

6.2 CHANGING WORLD ECONOMIC CONDITIONS ARE CAUSING A DECLINE IN THE USE OF RECOVERED TEXTILE MATERIALS

The U.S. textile industry is not currently using reprocessed materials primarily because of the high quality requirements placed on it by tine U.S. consumer. Unlike consumers in many less-developeci countries, the American consumer demands a very high quality textile product. To achieve this quality, it is often necessary to treat textile products with various irreversible finishing processes (see Chapter 7).

Apparently, the technological obstacles to producing such high-quality goods from contaminated textile waste are presently insurmountable. The waste fibers are contaminated by the various textile processes, garment fabrication processes, and consumer wear and care. Many of these processes have irreversible effects and cause the material to be unmarketable.

The standard of living enjoyed by U.S. consumers is strikingly different from that for consumers in lessdeveloped countries. This difference partially accounts for llie difference in market response to textile products manufactured from reprocessed materials. A direct relationship has been found to hold between the level of economic development and the quantity of utilized reprocessed material. This relationship is evident in the the United slates and in many European countries as well. intil 1945, textile waste reprocessing was widespread on both continents, especially in woolen goods. Since 1945 and the end of World War II, reprocessing in the U.S. has drastically declined. Most European countries have also stopped using reprocessed materials in their first tier textile mill products industries as indicated by recent reports from the Organization for Economic Cooperation and 
Development (OECD). The OECD's analysis of textile reprocessing in Denmark summarized the consumer response to reprocessed materials as follows:

"The small-scale post-war industries based on used textile products have vanished long ago, as a product manufactured from waste material has little chance of meeting the quality standards now stipulated." 10

The economic structure of the U.S. textile mill products industry is also considerably different from those of textile industries in countries that use waste for first tier textile products. Some foreign textile industries enjoy monopolistic environments quite unlike the highly competitive condition under which their U.S. counterparts operate. The U.S market situation necessitates a high degree of compliance with consumer demands.

U.S. and foreign markets also differ significäntly in labor costs. The U.S. textile worker enjoys far better wages and benefits than his counterpart in spain or Italy (countries that still make use of reprocessing). This makes the American textile product more labor-cost intensive and less suceptible to changes in the price of textile fibers. In the U.S., this labor cost difference also further reduces still further the benefits attainable from less expensive waste materials. The labor intensive nature of recycling, which involves such activities as hand sorting and grading, makes the economics of reprocessing far less attractive in a high labor cost environment. The effect of rising labor costs on textile waste reprocessing is described in an OECD international report, as follows :

\footnotetext{
"For some years past, the recovery of textile fibers for spinning has greatly declined in Belgium, owing to the high level of wages and the use of ultra-rapid spinning machinery which can only work with new raw materials. "10
}

The American waste collecting infrastructure does not provide a large amount of post-consumer waste. In the earlier part of the 20 th century, this was not true, and the push-cart, rag collector's call was a common occurence. These services are no longer available though limited collecting of post-consumer garments is done by 
some charitable organizations. The loss of the independent collector infrastructure was brought about by the following events:

Social changes, such as public assistance, made rag collection unattractive.

- Local licensing requirements made it more difficult to collect and peddle rags.

- Enactment of the Wool Labeling Act eliminated the rag collector's most valuable market.

- Development of blended yarns raused a change in the fiber content of the garments, causing fabrics made from such yarns to be unsuitable. for certain applications. This further reduced the economic incentive for collection.

- Changes took place in the disposal habits of the consuming public. Textiles now are often downgraded into rags for. home use, further reducing their economic value.

6.3

RECOTERED MATERIALS ARE SOMETIMES USED IN TEXTILE INDUSTRIES OUTSIDE THE UNITED STATES

Text1le industries in some foreign countries reuse primary textile waste, waste by-products, and secondary (post-consumer) waste in lower quality textile proulucts. In Eurnpe, wool is graded, broken down into fibers, and respun into low-end blankets and some clothing, as well as occasionally being exported to the IInited statca. Ful crample, luw quality blankets containing reused wool are sometimes purchased by the Red Cross. Some sweaters made with a portion of reprocessed wool fibers are sold through the discount slures in this country. However, the production of goods with recycled fibers does not include first quality garments. The shorter fiber length and the degradation of the fiber material through use and line unspinning and unweaving processes made the producing of first quality goods impossible. Products made from recycled fibers, while acceptable in certain foreign markets, do not compete well with 100 percent virgin wool products produced in this country. 
Other fibers are also reprocessed in foreign countries. The 100 percent cotton T-shirt cuttings from Japan have been broken down into basic fibers and rewoven into second- quality fabrics in spain on slow-running processing and weaving machines. This is economically feasible for a number of reasons:

- The labor rates are lower, allowing for lower unit costs of production.

- The collection and grading infrastructure for secondary waste is better developed, allowing favorable selection and use of garments.

- Restrictive labeling laws are not as prevalent, allowing a higher percentage of reused materials to be used in garments with little or no labeling required.

- Processing equipment is relatively inefficient, and consistent operation is not a prime consideration for economic existence.

- Additional capital expenditures to meet environmental or industrial safety standards are not required in many foreign countries.

These factors all combine to allow the foreign recycling industries to produce garments and products that are accepted and economical in their markets. These same items woùld be generally unacceptable in the U.S. market.

6. 4 THE USE OF RECYCLED MATERIALS FOR PRODUCING FINISHED GOODS OCCURS MOSTLY IN THE SECOND TIER OF THE TEXTILE MILL PRODUCTS INDUSTRY.

The second tier subsectors of the textile mill products industry are the major users of the primary waste and byproducts generated in the manufacture of textile products. The waste is often purchased directly from the fiber producers (chemical companies outside the textile industry) and from various segments of the textile industry (see Figure 6-4). The types of waste used by each of the second tier producers are discussed in the following sections. 


\section{FIGURE 6-4}

Sources of Recovered Materials for Textile Industry Subdivision Utilizing Recovered Materials

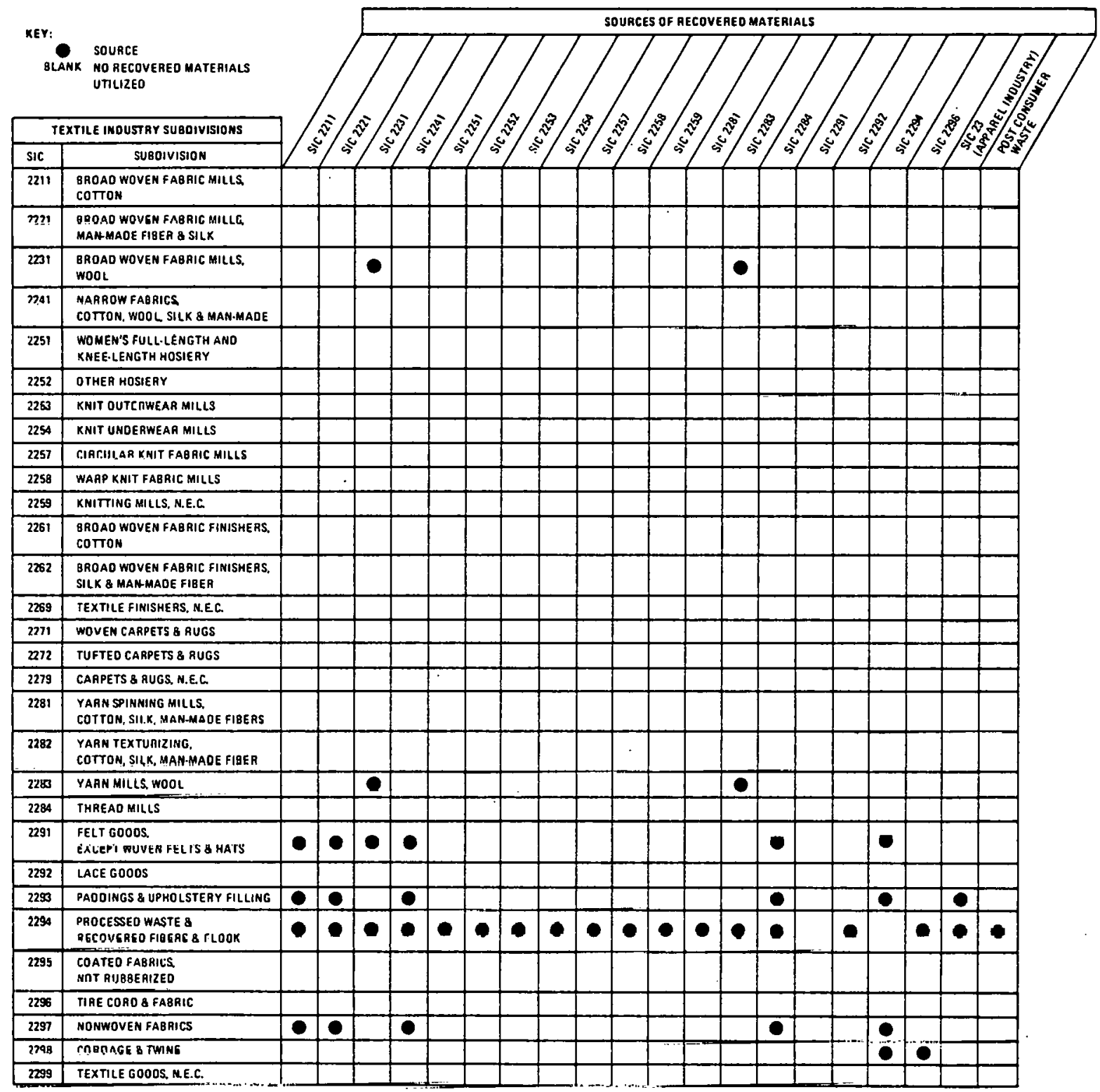


A very broad classification of waste has been used to completely document the waste and by-product flows throughout the industry. Any material considered off-quality or unusable in one sector is classified as a waste by-product if it can be used in another sector. For example, 100 percent virgin tire yarn is classified as primary waste if it is used in the manufacture of cordage after being rejected by the tire cord industry because of a slight variation in size. The material has not been reprocessed or altered in any way, but it is still considered a recycled product.

Some of the second tier textile industries can use off-quality or reprocessed material in products hidden beneath other layers of fabric. The material is not required to exhibit the consistency in color or texture required of the outerwear produced in the first tier of the industry. This eliminates many of the problems associated with dyeing, finishing, and weaving of recycled fibers.

The segments included in the second tier of the textile industry, classified by end product, are as follows:

- Felt goods, except woven felts and hats (SIC 2291)

- Paddings and upholstery filling (SIC 2293)

- Tire cord and fabric (SIC 2296)

- Nonwoven fabrics (SIC 2297)

- Cordage and twine (SIC 2298).

Since these groups are refined according to the Standard Industrial Classification system, the categories are broad and include a variety of finished products (see Appendix B). The following sections discuss current recycling in each of these subsectors. 
6.4.1 Felt Goods, Except Woven Felts and Hats (SIC 2291)

A significant portion of pressed felt goods is produced with recycled fibers. The primary source of this material is the textile waste sector (SIC 2294). The felts, used in automobiles (for soundproofing and insulation) under carpets, as padding, etc.) are generally not visible. Consequently, the color of the material is unimportant and slight variations in texture, including knots, lumps, different sized fibers, and gaps in the material, are often acceptable. Because most felts are produced for nonvisible use, they include high percentages of recycled waste. The waste used includes synthetic and natural fibers that are chopped, shredded, opened, or picked into a fibrous state. Through the application of heat, moisture, and pressure, these fibers are formed into a pressed felt.

\subsubsection{Paddings and Upholstery Filling (SIC 2293)}

Padding and upholstery filling are composed primarily of recycled materials. The padding, exclusive of the foams produced by the chemical industry, is usually chopped, picked, or garnetted waste from the textile mills or the waste by-products dealers. This material is used as stuffing in sleeping bags, beds, pillows, upholstery, and similar objects. Properly prepared reprocessed fibers are fluffy and incupcnsive; and, since they are Hul visdble in use, their color is not generally an important consideration. Certain applications may require a bleached product, but the color need not be as consistent as it is in the apparel trade. A certain amount of padding sometimes contains virgin fibers when a consistent feel is required and cannot be achieved using a waste product. When flame retardation is required, a layer of virgin polyester is often used as a flame barrier, or the padding may be chemically coated to resist burning. 
6.4.3 Tire Cord and Fabric (SIC 2296)

The makers of tire cord and fabric have very high strength and durability requirements. The cord and fabric constitute only a small part of the total value of the finished tire, so the savings that might be realized through the use of recycled or off-quality fibers are not a significant factor. In addition, the Department of Transportation requires product quality and consistency which reinforces the stringent internal company standards. This causes the industry to reject even a certain portion of the virgin tire yarn produced. Rejection could occur for a number of reasons, including failure to meet specifications on elongation, tensile strength, or shrinkage. In fact, if even the fugitive tint is wrong (the color used to identify a certain size or quality of fiber), the fiber will be rejected, even though its other properties are acceptable. These factors all tend to discourage the use of any recycled or off-quality fibers in this subsector.

$6.4 .4 \quad$ Nonwoven Fabrics (SIC 2297)

Some nonwoven fabrics consist of recycled fibers. Certain nonwovens are used in padding and insulation where color is not as important as product density or thickness. Nonwovens used in automobile headliners and low-end sleeping bags need not meet the same fashion and feel requirements that nonwovens used in outerwear must meet. For this reason, the use of various natural and synthetic comber and thread waste is acceptable.

Spun bonded nonwovens must contain only virgin fibers because of the nature of the manufacturing process (extrusion of fiber from raw pellets or chips of synthetic materials). However, various other processes can readily accept by-products. Recycled fibers are not used in diapers, sanitary pads, and surgical gowns, because requirements for cleanliness and purity are quite stringent as are the labeling requirements of the Medical Devices Act.

6.4.5 Coriage and Twine (SIC 2298)

Cordage and twine produced in the United States contains a large amount of off-quality or reprocessed waste. 
The tire yarn rejected by the tire cord and fabric industry is considered a waste by-product when used in this subsector even though it is 100 percent virgin material. The use of other recycled staple and natural fibers, such as jute and sisal, also occurs in the production of cordage and twine. This is done when high strength is not required in the final product.

The by-products industry is active in the preparation of these waste materials. Mop yarn and lower quality clothes lines are often produced from a high percentage of recycled fibers. The segment of the industry that produces cordage for marine applications and other uses where high strength is a necessity, uses some rejected tire yarn, but relies more heavily on first quality material.

This chapter has discussed how recovered materials are currently used in the textile mill products industry. The following chapter discusses the factors that limit recycling, confining it to the relatively low level of activity found in the United states today. 


\section{CHAPTER 6 SOURCES}

1. Battelle Columbus Laboratories, A Study to Identify Opportunities for Increased Solid waste Utilization, Volume IX, prepared for the Environmental Protection Agency, 1972 .

2. Conversations with various private rag collectors.

3. Private communications with various textile associations.

4. Conversations with various private textile companies.

5. Environmental Protection Agency, Development Document for Effluent Limitations Guidelines and New Source Performance standards for the Textile Mill Point Category, June 1974 .

6. Environmental Science and Technology, "An ES\&T Special Report--SOLID," May 1970.

7. "Guide to Nonwoven Fabrics, "International Non-Wovens and Disposable Association (INDA), 1978

8. A. T. Luey, Technological Advances in Secondary Fiber Usage, 1970

9. G. Lund, (Shirley Institute, England), "Recycling in the Garment Industry," Clothing Institute Journal, vol. 23.

10. Organization for Economic Cooperation and Development, Impact of Changes in the Availability and Prices of Energy and Textile Raw Materials on the Future Activities of the Textile and Clothing Industry, 1976.

11. Marshall Sittig, Resource Recovery and Recycling Handbook of Industrial Wastes, Noyes Data Corporation, 1975 .

12. Textile Organon, "Man-Made Fiber Waste Production," June 1968. 
13. Textile organon, "U.S. Mill Consumption of Fiber and Domestic Consumption of Fiber and Products" and "U.S. Import of Man-Made Fibers," September 1978.

14. U.S. Department of Agriculture, Marketing and Utilization of Cotton Mill Waste, March 1967.

15. Versar, Inc., Assessment of Industrial Hazardous Waste Practices, Textiles Industry, prepared for the Environmental Protection Agency, June 1976.

16. Wool Industries Research Association (England), Fiber Reclamation - the Man-Made Fiber Problem, WIRA Report No. 160, January 1972 .

17. Wool Industries Research Association (England), Reclamation of Textiles Waste, WIRA Report No. 130, January 1971 . 


\section{LIMITATIONS ON THE USE OF RECOVERED MATERIALS IN THE U.S. TEXTILE MILL PRODUCTS INDUSTRY}

Limitations on the reuse of textile fibers and yarn are created in part by stringent demands for product quality and by requirements that the products have certain characteristics. Satisfactory products result when the various elements of the spinning, weaving, and finishing processes are closely controlled. Some of the elements that must be controlled are as follows:

- The quantity of short, immature, natural (cotton or wool) fibers in the basic yarn

- The quantity, type, merge, and lot number of man-made fibers included in blended yarns and fabrics

- Various processes that irreversibly change the character or chemical/physical makeup of fibers and yarns, particularly man-made fibers and continuous.filament.

The following paragraphs describe how these elements can affect the use of recovered materials in the textile mill products industry.

The picking, carding, and combing operations in the initial stages of the spinning process remove foreign matter, align fibers, and remove shorter and undesirable fibers. Natural cotton fibers are up to $1-5 / 8$ inches long. For first tier quality yarn, fibers less than $7 / 8$ inch in length are removed. These shorter fibers tend to lend a bulkiness and uneven surface to the resulting yarn and fabric, giving them undesirable strength, feel, appearance, and dyeability characteristics. In some lower quality goods these shorter fibers are permissible, but most of the fibers are relegated to the second tier of the industry. Some very fine cotton products (combed cotton) have additional filuers combed from the sliver to give a lustre or high sheen to the final fabric. Yarn and fabric are tested extensively to control the quantity of these short fibers. This is done on a continuous basis by both the textile $\mathrm{mill}$ and the intermediate customer (apparel, government, or chain retailers). 
Currently and in the foreseeable future, there are no technologies available to reduce yarn or fabric waste to the fiber form without producing a predominance of very short fibers ( $1 / 4$ inch or less). (Yarn and fabric waste are the major non-reworkable primary and secondary wastes available for reuse in the textile mill products industry.) Using fibers reclaimed from yarn or fabric waste or from secondary waste to produce first tier products would result in products with inferior characteristics and would be unacceptable to intermediate and final consumers. Some yarn from these types of fibers is respun in Southern Europe and the Far East, but the resulting fabrics are unacceptable for the U.S. market. Problems with short fibers severely limit the use of yarn or fabric waste and secondary waste as recovered materials in the textile mill produrts industry.

Continual development and product improvement in the textile mill products industry led to the extensive use of man-made fibers and continuous filament in the manufacture of textile products. These man-made fibers and filaments (polyester, nylon, acrylic, etc.) expand the versatility of the final product, because the man-made fibers have a wide variety of possible characteristics, depending on the following:

- Basic chemical composition

- Variations applied to the chemical compusition

- Processing methods for the basic fiber and filament, including texturising

Dyeing and finishing processes

Types ot dye stuff and auxiliary chemicals used.

Various bleisle of collun, wool, and man-made fibers can give the intermediate and final consumers almost any fiber characteristic desired. This is done on a continuous basis as processors try to generate a growth segment of the market or to gain brand identification in a lisyhly competitive industry. Many textile firms have 200 or more blends that they fabricate for specific customers.

The existence of the extremely large number of blended yarns and fabrics and the sensitivity of the man-made tibers and filament to process changes limit the possible reuse of 
primary and secondary waste to make first tier products. Since the man-made fibers and filament are so sensitive to process changes, the chemical and textile mill products industries carefully control their production. The fibers and filament are so sensitive to change that a merge number is assigned to each process set-up in a fiber plant. Any time a process change of any kind is made, the merge number is changed. The producer specifies processes, dyestuffs, and auxiliary chemicals and guarantees dyeability within a merge. Shipments or orders to a customer are assigned a lot number within a given merge. Merge numbers and lot numbers are seldom mixed because of the likelihood that yarns and fabrics would not be consistent.

llatural and man-made fibers are also carefully controlled at the textile mill. As mentioned, lot numbers and merge numbers of man-made fibers are seldom mixed. Cotton fibers, which arrive by numbered bale, are tested for maturity and fiber length distribution (micronaire). During the blending process, several bales with averages at the desired micronaire level are mixed layer by layer to give as much consistency as possible. In the blending of $60 / 40$ cotton, man-made fiber, the fibers are measured in 60- and 40-ounce increments to help ensure consistency. One facility receives continuous filament yarn at the rate of a truckload per day. The yarn is mixed from three consecutive truckloads, all within the same lot number and merge number, in order to improve the yarn's consistency.

Examination of records made available to those preparing this report indicated that the major cause of customer claims against the textile mill products companies is variation in color shade (level) and dyeability failures. Laboratory reports indicated several causes for these failures predominate:

- Dyeability variation in a yarn of fixed chemical composition, type, merge number, and lot number.

- Inconsistency in blends. Differences as small as 0.2 percent of the total composition can cause variations in the dyed fabric or yarn.

- Traces of another man-made fiber in the specified fiber can cause different dye characteristics. 
Many of the processes to which natural and man-made fibers, yarn, and fabrics are subjected are irreversible. This position is maintained by polymer chemists in universities and industry alike. For example, the twist imparted to yarn for strength during the spinning process is permanent once the fiber passes through subsequent dyeing and finishing processes. This is particularly true of man-made fibers after the heat-setting treatment, which all of them undergo.

These irreversible processes essentially modify the chemical/physical structure of the fibers so that their performance characteristics change. Therefore, a fiber is likely to have a set of characteristics in its seoond processing much different from the set it had in its first processing. This imposes a tremendous limitation on the reuse of any textile yarn or fabric, particularly secondary or post-consumer waste. Even though the Textile Labeling Act requires identification of fiber blends, small percentages are grouped and the indications are too imprecise for the textile processur. Additionally, making a first tier product requires knowing the precise fraction of each fiber present. For man-made fibers, the fiber manufacturer, merge number, and lot number must also be known, and it must be possible to use this information to achieve the desired blend. For economics, it would be required that sufficient quantities of the fiber by lot number and merge number be available to operate the textile mill. All of these items impose severe limitations on the use of recoverad materials in the textile mill products industry. These various factors are discussed further in the sections that follow.

7.I THE QUALITY OF TEXTILE PRODUCTS GOVERNS THEIR MARKETABILITY

As indicated in Table 7-1, the textile mill products industry ships its products to three primary markets:

- Apparel industry (apparel fahrja)

- Direct retail outlets (home furnishings and other consumer products)

- Export market.

The major customers of the industry are the apparel industry and retail chains. The quality and product characteristics demanded by these intermediate customers 
TABLE 7-1

Total Textile Industry Fiber Consumption by End Use

\begin{tabular}{|c|c|c|c|c|c|c|c|c|c|c|c|c|}
\hline & \multicolumn{3}{|c|}{$\begin{array}{l}\text { TOTAL CONSUMPTION } \\
\text { OF ALL FIBERS }\end{array}$} & \multicolumn{3}{|c|}{$\begin{array}{l}\text { TOTAL COTTON } \\
\text { FIBER CONSUMPTION }\end{array}$} & \multicolumn{3}{|c|}{$\begin{array}{l}\text { TOTAL WOOL } \\
\text { FIBER CONSUMPTION }\end{array}$} & \multicolumn{3}{|c|}{$\begin{array}{l}\text { TOTAL MAN-MADE } \\
\text { FIBER CONSUMPTION }\end{array}$} \\
\hline & 1971 & 1973 & 1976 & 1971 & 1973 & 1976 & 1971 & 1973 & 1976 & 1971 & 1973 & 1976 \\
\hline $\begin{array}{l}\text { TOTAL END USE CONSUMPTION } \\
\text { (IN MILLIONS OF POUNDS) }\end{array}$ & 10,619 & 12.491 & 11,744 & 3,933 & 3,743 & 3,516 & 261 & 221 & 163 & 6.425 & 8.527 & 8.065 \\
\hline APPARELL & 4,687 & 5,326 & 4,940 & 1,857 & 1,762 & 1.737 & 162 & 134 & 116 & 2.668 & 3.420 & 3,087 \\
\hline HOME FURNISHINGS & 3,340 & 3,900 & 3,545 & 1,230 & 1,092 & 941 & 85 & 53 & 33 & 2.025 & 2,755 & $2,57 !$ \\
\hline $\begin{array}{l}\text { OTHER CONSUMER-TYPE } \\
\text { PRODUCTS \& INDUSTRIAL USES }\end{array}$ & 2,341 & 2,839 & 2,757 & 696 & 669 & 571 & B & 9 & 7 & 1,637 & 2,161 & 2,179 \\
\hline EXPCRTS OF DOMESTIC PRODUCTS & 251 & 426 & 502 & 150 & 220 & 267 & 6 & 25 & 7 & 95 & 181 & 228 \\
\hline
\end{tabular}


determine the type and quality of products produced. The apparel industry is a good example of the control exercised by the intermediate consumer.

\subsubsection{Economic Importance of the Apparel Industry}

The following points make clear the size and economic importance of apparel manufacturing:

- It ranks sixth in the number of manufacturing facilities, with 15,000 firms and 16,000 plants.

- It is the third largest employer of manufacturing workers (after food and automotive), with 1.3 milliun employees.

- It is the third largest consumer industry, having a projected $\$ 40$ million wholesale volume for 1979 .

- The industry consumes over 40 percent of the total output of the textile mill products industry.

The apparel industry has tremendous influence on the textile mill products industry and tries to persuade that industry to conform to its requirements and specifications. Also, the competitiveness of the textile mill products industry allows the apparel industry to nove from one company to another with relative ease. The textile companies are eager to keep accounts, and their extreme reluctance to lose husiness to a competitor tends to keep a downward pressure on prices and an upward pressure on quality.

The results of this oituation are indicated in Table 7-2, which shows a typical cost structure for a U.S. apparel manufacturer, Net income is approximately 2.5 percent of net sales; however, returns, allowances, and discounts which go back primarily to the textile mill products industry, are 5 percent. With the low protitability of the industry, twice the industry's net income is provided by returned goods, indicating the importance of quality and acceptable characteristics to the apparel industry.

\subsubsection{Seasonal Impact on Apparel Industry}

Time and season have important effects on the apparel industry. The purchasing, manufacturing, sales, and shipment of apparel items are all strongly influenced by 
TABLE 7-2

Costs for a Typical U.S. Apparel Manufacturer

\begin{tabular}{|lc|}
\hline & AVERAGE \\
GROSS SALES & $105.0 \%$ \\
RETURNS, ALLOWANCES, DISCOUNTS & 5.0 \\
NET SALES & $100.0 \%$ \\
FACTORY COST OF GOODS SOLD: & \\
BODY GOODS, LINING AND TRIM & $40.8^{1}$ \\
OTHER MATERIALS USED & 6.6 \\
DIRECT LABOR & $17.0^{2}$ \\
INDIRECT LABOR & 2.7 \\
ALL OTHER FACTORY COSTS & 9.9 \\
TOTAL FACTORY COST OF GOODS SOLD & $77.0 \%$ \\
SHIPPING AND SELLING EXPENSES & $12.1^{3}$ \\
ADMINISTRATIVE EXPENSES & 5.3 \\
TOTAL OPERATING COSTS & $94.4 \%$ \\
\hline OPERATING PROFIT BEFORE TAXES & \\
AND OTHER INCOME/EXPENSES & 5.6 \\
NET INCOME AFTER TAXES & $2.5 \%$ \\
\hline
\end{tabular}

${ }^{1}$ MATERIAL IS ROUGHLY $40 \%$ OF COSTS

${ }^{2}$ CUTTING LABOR IS $\pm 1 \%$ OF COSTS (ON A COMPOSITE AVERAGE)

${ }^{3}$ SHIPPING LABOR LESS THAN $1 \%$ OF COSTS (ON A COMPOSITE AVERAGE) 
seasonal fluctuations in consumer demend and buying preferences. Table 7-3 gives the separate marketing seasons in apparel.

Currently, the average men's wear manufacturer has two to three marketing seasons each year, and the average ladies' wear manufacturer has five to six such seasons per year. The trend has been, and continues to be, the creation of additional marketing seasons. This shortens the amount of time available for the forecasting of sales, purchasing of fabric and trim, preparation of samples and cost data, installation of new equipment, training of employees, adoption of quality standards, and shipment of completed garments. Any analysis of the apparel industry must take this time rcquimpmerl into considelatlon.. 'l'he requirement makes it lmperative that the textile mill products industry operate with high speed, efficient equipment in order to respond to rapid changes in the apparel industry's needs.

\subsubsection{Trends in the Apparel Industry}

During the last two decades, the apparel industry has started to polarize. About 98 percent of its companies remain small, privately-owned, and entrepreneurial, but they account for less than one-third of total shipments. The other 2 percent have grown rapidly, gone public, or been acquired by multi-industry conglomerates.

The firms in the 2 percent group have tremendous buying power. As a result, they also have the power to demand quality and specific characteristics from a textile firm. If a textile firm loses one of these major apparel companies as a customer, there is only a limited number of significant accounts among which the textile firm might find a replacement for the lost account.

As indicated in Table 7-2, fabrir is the largest single cost factor for a U.S. apparel manufacturer. Normally, fabric is twice as large as labor, the next most significant cost factor. This explains why most. recent technological dovelopments in the apparel industry have been implemented in the pre-sewing functional areas such as pattern layout, cutting, etc. This also explains why so much pressure is exerted on the textile producers to provide high quality goods with specific characteristics. 
TABLE 7-3

Marketing Seasons in the Apparel Industry

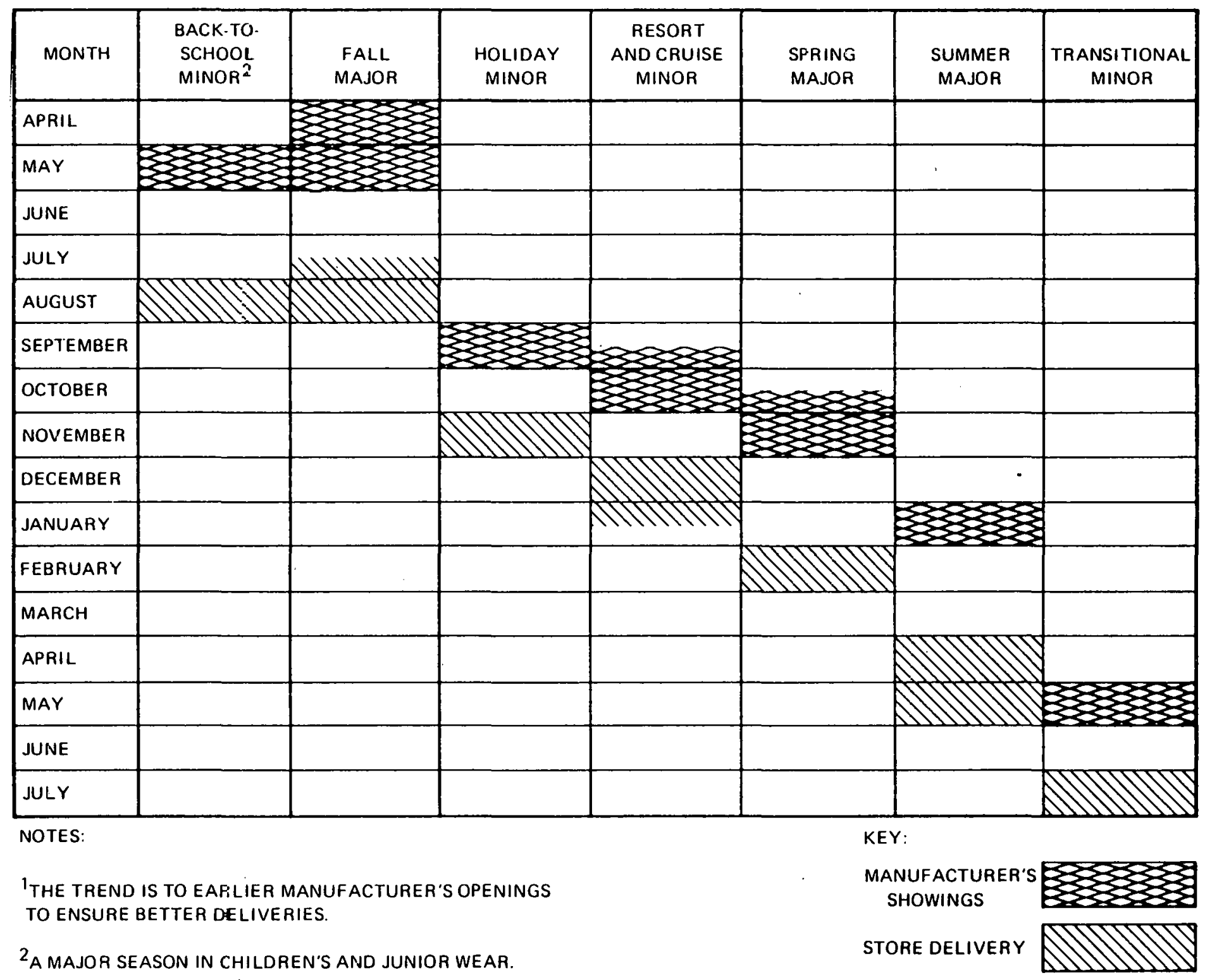


Table 7-4 gives the results of a recent survey by Kurt Salmon Associates. The survey points up the proliferation of man-made fibers and their continuing influence on the apparel industry. When these fibers are blended with cotton, the resulting product has characteristics most acceptable to the apparel marketplace. It is anticipated this trend will continue to be true. Coupled with the stringent quality criteria imposed by the apparel industry on the textile mill products industry, the increased use of blended fibers will limit the ability of the textile industry to reuse recovered materials to produce first tier products.

\subsubsection{Quality Control In the Apparel Industry}

In the past, many apparel manufacturers placed the burden of raw material quality almost entirely on their suppliers. Often this was done without telling suppliers the product to be made or the expected end use. Now, apparel manufacturers, especially the larger firms, are purchasing by specification. The properties of the raw material affect not only its handling characteristics during production, but also the quality of the final product. Any change in the properties of the raw material will change handling methods during production, the behavior of the final product, or both. If there is to be any continuity in production and product quality from lot to lot and style to style, there must be some assurance that the raw material properties will not change. Practical specifications must therefore be set and followed for all critical raw material. characteristics.

Fabric specifications must be such that the fabric can be handled with existing machinery, skills, and with no significant deviations from consumer expectations. Thus, fabric specifications fall into two categories, those governing fabric performance during garment manufacture and those governing garment performarice during use.

In the first category, performance during manufacture, the fabric properties that must be sperified are those that aflect the following:

- Handling on the cutting table and the cutting itself

- Sewing and handling during sewing

- Garment finishing. 
TABLE 7-4

Current and Projected Fiber Content in Apparel Products*

\begin{tabular}{|c|c|c|c|c|}
\hline \multirow{2}{*}{ FIBER CONTENT IN APPAREL PRODUCTS } & \multicolumn{4}{|c|}{ YEAR } \\
\cline { 2 - 5 } & 1972 & 1976 & 1985 & 2000 \\
\hline COTTON & 37 & 35 & 32 & 29 \\
\hline WOOL & 3 & 2 & 2 & 2 \\
\hline $\begin{array}{c}\text { NON-CELLULOSIC SYNTHETICS } \\
\text { (POLYESTER, NYLON, ACRYLIC) }\end{array}$ & 48 & 57 & 60 & 63 \\
\hline $\begin{array}{c}\text { CELLULOSIC SYNTHETICS } \\
\text { OTHER }\end{array}$ & 12 & 6 & 5 & 4 \\
\hline
\end{tabular}

"KURT SALMON ASSOCIATES DELPHI SURVEY 
In the second category performance during use, the fabric properties that must be specified are those that affect garment wear, renovation, or alteration. Actual requirements vary greatly from one product to another and must be separately determined for each end-use item. The buyer knows his requirements in detail, and the seller must know the specifications of his product in the same detail.

Fabric quality specifications generally include the following:

- Physical characteristics-weight, fiber content, count, feel (hand), type of finish, finished width, etc.

- Performance characteristics-colorfastness, shrinkage, durable press features, strength, care characteristics, flame retardant features, etc.

- Visual defects-grading system and acceptable level

- Shade tolerance variation-shade range between and within shipments, bales, or pieces

- Put-up-package type and size, piece lengths or diameters, tube type, ticket information, etc.

- Test methods or procedures-used to ensure compliance with the stated requirements.

In order to produce a quality product at a reasonable cost, the apparel industry determines raw material requirements prior to dealing with the textile mill products industry. After the requirements are set, they are com municated to the textilc supplier, and the raw materials characteristics are chosen. The specifications are exactly as indicated in the Specification Data sheet (see Table 7-5).

Reaching an agreement with a textile manufacturer on physical and performance characteristics and packaging (put-up) are generally the easiest steps in setting specifications. The areas requiring more study are visual defects and shade variation. Several systems are used by the industry to determine visual quality. Any evaluation 


\section{SUGGESTED FABRIC SPECIFICATION DATA SHEET}

To be prepared by fabric supplier and given to buyer at the time of sample submission.

Fabric Manufacturer:

Fabric Brand Name:

Contract No.:

Date:

riber Content:

Construction Name:

Special Finish:

YARNS:

Generic Title: Size of Yarn(s): Warp/

Fill/

Wales:

Course:

No. of turns per inch: Warp/Wales:

Texture Type: Warp/Wales: Course/Fill: Course/Fill:

Construction Description:

Warp/Wales: Course/Fill: Finished Width

Weight: Per sq. yd. oz. \pm Per linear yd. oz. \pm

End use of the fabric:

\begin{tabular}{|c|c|c|c|}
\hline Property & Perfor & e Level & Test Method \\
\hline $\begin{array}{l}\text { STRENGTH: } \\
\text { Tensile (W/F) } \\
\text { Tear (W/F) } \\
\text { Bursting }\end{array}$ & Average & Minimum & $\begin{array}{l}\text { ASTM-D } 1682-64 \\
\text { ASTM-D } 1424-63 \\
\text { ASTM-D } 231-62\end{array}$ \\
\hline STRETCH: $(W / F)$ & & & ASTM-D 2594-72 \\
\hline $\begin{array}{l}\text { SHRINKAGE: } \\
\text { 1. Hothead Pressing (W/F) } \\
\text { 2. Home Laundry \& } \\
\text { Tumble Dry }(W / F)\end{array}$ & & & $\begin{array}{l}\text { 1. As agreed between } \\
\text { buyer and seller } \\
\text { 2.AATCC-124-75 }\end{array}$ \\
\hline $\begin{array}{l}\text { ABRASION: } \\
\text { Describe Method: } \\
1 . \\
2 . \\
\end{array}$ & & & ASTM-D 1175-71 \\
\hline
\end{tabular}


Property

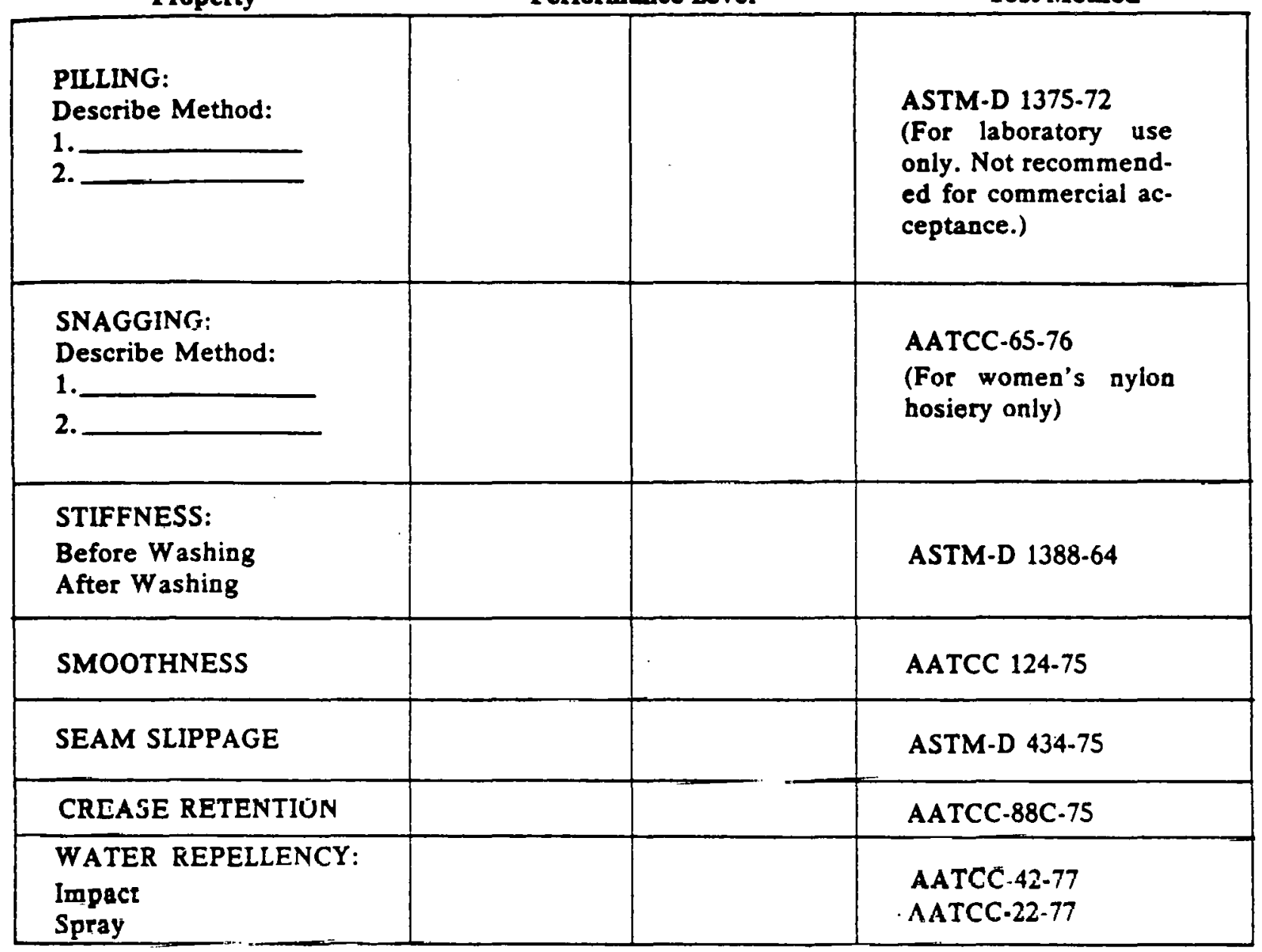

\begin{tabular}{|l|c|c|}
\hline \multicolumn{1}{|c|}{ Colorfastness } & Minimum Rating & Test Methud \\
\hline Lauudering (C/S) & & AATCC-61-72-AATCC-124-75 \\
Crocking (W/D) & AATCC-8-77 \\
Light & & AATCC-16A-7i \\
Puropiration & AATCC-15-76 \\
Atmospheric gases & AATCC-23-75 \\
Clorine Rctention & & AATCC. $3-75$ \\
\hline
\end{tabular}

\begin{tabular}{|l|l|l|l|}
\hline Visual Defects & $\begin{array}{c}\text { Performance } \\
\text { Level }\end{array}$ & Lot Maximum & Roll Reject \\
\hline $\begin{array}{l}\text { Points Por } 100 \\
\text { Square Yards }\end{array}$ & & & \\
& & & \\
\hline
\end{tabular}




\section{COMPLIANCE WITH SPECLAL REQUREMENTS ON PRODOCT}

Mandatory Government Requirements:
(A.) F.T.C. Permanent Care Labeling:
(B.) F.T.C. Fiber Identification:
(C.) Country of Origin (where applicable)
(D.) Other:

\section{Package and Packing Requirements:}

Rolls Flat Fold Yds/each, Min. Max.

Max. no. of pieces/put up Length of shortest piece

\section{Wrapper:}

Data on tag:

Mfg. Name

Style No.

Color

Gr. Wt.

Brand Name

Piece No.

Gr. Yds. Net Yds.

New Wt.

Shipping Case: One shade per case

Label on outside of case to describe content:

Date of shipment Other

Special Instructions:

Date Salesman

Date Other 


\section{THIS PAGE}

\section{WAS INTENTIONALLY LEFT BLANK}


RAW MATERIAL MUST BE CONSISTENTLY HIGH IN QUALITY FOR THE TEXTILE MILL PRODUCTS INDUSTRY TO MEET PRODUCT SPECIFICATIONS

Consumers demand uniform appearance, texture, and color in textile fabrics used for apparel and home furnishings. Even when nonuniform effects are desired (printed fabrics, textured fabrics, etc.), they must be either totally random or incorporated in a well defined and controlled pattern. Meeting the consumer's uniformity demands requires careful control of raw materials and processes at every step in the textile production process. Examples of a number of control practices are given in the following paragraphs.

\subsubsection{Synthetic Fiber Manufacture}

A major portion of apparel and home furnishing fabrics is produced from synthetic fibers (polyester, nylon, acrylic, polypropylene). These fibers are produced in two forms-continuous filament and staple (short length) fibers. Using quality control procedures to ensure fiber uniformity is a major task in synthetic fiber production.

Control begins with the incoming raw materials. Special grades of chemical raw materials designated "fiber grade" or "polymer grade" chemicals are among the most stringent in the chemical industry. Typical specifications for "fiber grade" terephthalic acid for polyester fiber manufacture are shown in Table 7-6. These specifications place extreme demands on the chemical industry, since the chemicals must be of high purity but must still be produced in large volumes. Deviations from these specifications cause polymers to have a molecular weight lower than those required (resulting in lower fiber strength or colors lighter than can be tolerated in fabric production).

Different fiber lots have different dyeing characteristics, making it difficult for fiber manufacturers to achieve color uniformity. If all yarns in a fabric do not accept the same quantity of dye, the different dyeing ends will be very apparent, showing as light or dark streaks in the fahric. Such a fabric is said to exhibit "barre" and is unacceptable for sale. This problem is compounded by the fact that most fabrics are dyed in the fabric form and barre problems are not detected until after the dyeing process. Thus, a manufacturer may have thousands of yards of defective fabric already in inventory before the barre problem is discovered. 
TABLE 7-6

Typical Specifications for Fiber Grade Terephthalic Acid for Polyester Fiber Manufacture

\begin{tabular}{|c|c|}
\hline ACID NUMBER (mg. KOH/gram) & $1.75 \pm .2 \mathrm{mg} / \mathrm{g}$ \\
\hline \multicolumn{2}{|l|}{ ALKALI EARTH METALS } \\
\hline $\mathrm{Ca}$ & 2 ppm MAX. \\
\hline No & 2 ppm MAX. \\
\hline K & 2 2 \\
\hline $\mathrm{Mg}$ & $2 \mathrm{ppm}$ MAX. \\
\hline 4-Carbonybenzoldehyde & 25 ppm MAX. \\
\hline \multicolumn{2}{|l|}{ HEAVY METALS } \\
\hline TOTAL & 10 ppm MAX. \\
\hline $\mathrm{Fe}$ & 2 ppm MAX. \\
\hline $\mathrm{Ni}$ & 1 ppm MAX. \\
\hline $\mathrm{Cr}$ & 1 ppm MAX. \\
\hline $\mathrm{Cu}$ & 1 ppm MAX. \\
\hline Mo & 1 ppm MAX. \\
\hline $\mathrm{Ti}$ & 1 ppm MAX. \\
\hline \multicolumn{2}{|l|}{ OTHER } \\
\hline$A R$ & 2 ppIn MAX. \\
\hline $\mathrm{Si}$ & 2 ppm MAX. \\
\hline MOISTURE & $0.5 \%$ MAX. \\
\hline COLOR (APHA 5\% SOLUTION) & 10 MAX. \\
\hline ASH & $15 \mathrm{ppm}$ MAX \\
\hline
\end{tabular}


Barre can arise from a number of different fiber variations. For example, many dyes used for nylon and acrylic fibers are attracted to the chemical group at the ends of the long polymer chains in the fiber. A slight difference in the number or types of end groups can alter the dyeing behavior. The dye uptake is so sensitive to end group concentration that it can be used as a quantitative analytical procedure for end-group analysis. This type of barre, frequently referred to as "chemical barre," is one of the major factors limiting the use of reprocessed man-made fibers. As the man-made fibers are melted and re-extruded in a process called glycolizing, the reformed polymer chains are of shorter length. on average and vary in size due to the losses and changes which occur in the end groups. These changes cause inconsistent dyeability in the fabric, a characteristic that is unacceptable to the apparel industry and to the final consumer.

Small differences in a fiber's solid state structure can affect the quantity of dye absorbed from the dye bath as well as the rate at which the dye is absorbed. The result is termed "physical barre." Most textile fibers consist of a mixture of highly ordered and disordered regions. The relative quantities of ordered and disordered materials, the size of the ordered regions, and the orientation of the ordered regions with respect to the fiber axis are functions of the temperature and tension to which the fiber has been exposed. Even small differences in these variables will cause differences in the fiber's solid state structure. Since the rate of diffusion of dyes into the fiber depends on the solid state structure, physical barre results in fabrics if the yarns have not been exposed to identical temperatures, and tensions for the same periods of time.

The actual physical structure of yarns can also lead to barre problems. If a yarn is small or larger than adjacent yarns in the fabric (due to bulk, tension in manufacture of the fabric, etc.), the human eye will perceive the structural differences as a dark or light streak. This is frequently referred to as "structural barre." Similar effects also occur if the fibers in a yarn have been damaqed (for example scraped or rubbed) during yarn or fabric production.

Uniformity requirements for textile fibers have led to the development of strict quality control standards in the manufacture of synthetic fibers. All synthetic 
fibers are shipped with a merge number clearly marked on the box or bale. Only fibers of the same type and with the same merge number can be used together in fabric production. If two different plants produce the same fiber product, the output of the two plants generally cannot be mixed in a fabric without uniformity problems; therefore, the fibers from the two plants are shipped with two different merge numbers. In many cases, fabric manufacturers only mix specific lots within a given merge number to further ensure product uniformity.

Mixing fibers within a given merge to yield a uniform fabric requires extensive testing by the fiber manufacturer. At one large fiber plant, 3,000 samples of production lots are treated with a sensitive dye and the color of the dyed fabric is measured pvery ray to dotoct productivil luts which may nut be mergable. Some synthetic fibers cannot be produced with sufficient uniformity to be sold in continuous filament form even when all available stateof-the-art production controls are used. In such cases, the fibers are cut into short lengths ( 1 to 6 inches) and sold as staple. This permits extensive blending to be done in operations like those used for natural fibers.

\subsubsection{Natural Fibers in Staple Fiber Processing}

Cotton fibers have variations that must be taken into account when the fibers are used to produce yarn and fabric. (This is true even of cotton fibers coming from the same field.) If the variations are not considered, the fabric will lack uniformity. The variations can be compensated for by putting the fibers through a series of blending operations. Similar processes are used to produce fabric yarn from staple synthetic fibers.

Opening is the first step in producing yarn from staple fiber. Fibers are usually blended during opening by feeding the opening line from 24 to 42 different bales. The fiber is then carded to produce a loosa rope of parallel fibers (sliver). A plant with four opening lines would thus process fiber from 96 to 168 hales at any given time.

The card sliver next goes through a series of drawing steps to further blend the fibers making the yarn more uniform. In drawing, six or eight card slivers are usually combined and drawn (or elongated) to give a single sliver. This process is repeated one or more times to ensure a uniform feed for the roving and spinning operations. 
Even if three of sour blending steps are used, fibers that exhibit significant dyeing differences produce a fabric with pronounced heather effect. In the dyeing of blends of cotton and polyester fibers, the fabrics go through two separate dyeing processes that dye both fibers the same shade (union dyeing) and thus avoid the heather effect.

\subsubsection{Avoigine Eiber Contarination}

Table 7-7 shows the number of different tyos of nylon "six-six" fiber that one manufacturer oroauces for on?y one end use (carpet manufacture). The 15 varieties of Eiber differ in the folloring points:

- Cross-sectional area-denier per filament

- Length-6.5- to 8-inch staple and continuous filament

- Lustre-amount of titanium dioxide added in polymerization

- Cross-sectional shape

- Type and quantity of dye uptake.

Fiber types must be rigorously segregated in carpet manufacturing to prevent one type from contaminating yarns of another fiber type. Elaborate labels are required on fiber raw materials to ensure proper identification (see Figure 7-1). In addition, the fiber manufacturer vor yarn producer usually applies a fugitive (easily removed) identification tint to the fiber. These pink, blue, yellow, green, etc. tinted fibers act to prevent the intermingling of fibers of different types. Without such ready identification, textile manufdcturers would have extreme difficulty in preventing fiber contamination.

Very thorough housekeeping practices are necessary to avoid contamination during changeovers from one fiber type to another and during times when two or more types of fiber are run in the same yarn manufacturing area. In changeover, all machines must be thoroughly cleaned, because even one small tuft of contaminating fiber in a yarn creates a light or lark defect in the final fabric. 
mypes of Nylon "Six-Six" Carpet Fiber Produced by One Fiber Manufacturer

\section{NYLON STAPLE}

\begin{tabular}{|c|c|c|c|c|c|}
\hline PRODUCT & DPF & $\begin{array}{c}\text { CUT } \\
\text { LENGTH }\end{array}$ & LUSTER & CROSS-SECTION & $\begin{array}{c}\text { DYE } \\
\text { LEVEL }\end{array}$ \\
\hline $1580-800-B 8 S$ & 18 & 8" & SUPERBRIGHT & TRISKELION & CATIONIC \\
\hline 1614-65ก-ABS & 6 & $6 \% 2^{\prime \prime}$ & SUPERBRIGHT & I RISKELION & REGULAR \\
\hline $1800-800-\mathrm{CBS}$ & 18 & $8^{\prime \prime}$ & SIIPERBRIGHT & TRISKELION & REGULAK \\
\hline $1810-750 \mathrm{CBS}$ & 18 & $7 \frac{1}{2} "$ & SUPERBRIGHT & TRISKELION & REGULAR \\
\hline 1879-800-FBS & 18 & 8" & SUPERBRIGHT & TRISKELION & DEEP \\
\hline \multicolumn{6}{|l|}{ ULTRON* } \\
\hline 1091-650-CES & 10 & $6 \frac{1}{2 "}$ & SUPERBRIGHT & TRILOBAL & REGULAR \\
\hline 1591-750-CES & 15 & $7 \frac{1}{2} \cdot$ & SUPERBRIGHT & TRILOBAL & REGULAR \\
\hline 1593-750-LES & 15 & $7 \% 2^{\prime \prime}$ & SEMIDULL & TRILOBAL & REGULAR \\
\hline
\end{tabular}

NYLON FILAMENT

\begin{tabular}{|c|c|c|c|c|}
\hline PRODUCT & DPF & LUSTER & CROSS-SECTION & DYE LEVEL \\
\hline $1230-68 \cdot C B \overline{8}$ & 18 & SUPERBRIGHT & TRISK.ELION & REGULAR \\
\hline $1300-136-C B 8$ & 10 & SUPERBRIGHT & TRISKELION & REGULAR \\
\hline 1860-05.CDO & 18 & SUPERBRIGHT & TRISKELION & REGULAR \\
\hline $2460-136-C 68$ & 18 & BRIGHT & TRISKELION & REGULAR \\
\hline $3690-204-C 68$ & 18 & BRIGHT & TRISKELION & REGULAח \\
\hline $1255.85-C B 8$ & 15 & SUPERBRIGHT & TRILOBAL & REGULAR \\
\hline \multicolumn{5}{|l|}{ ULTRON* } \\
\hline 1275-85-CBE & 15 & SUPERBRIGHT & TRILOBAL & REGULAR \\
\hline
\end{tabular}

DECEMBER, 1978 


\section{FIGURE 7-1 \\ Typical Shipping Labels for synthetic Fibers}
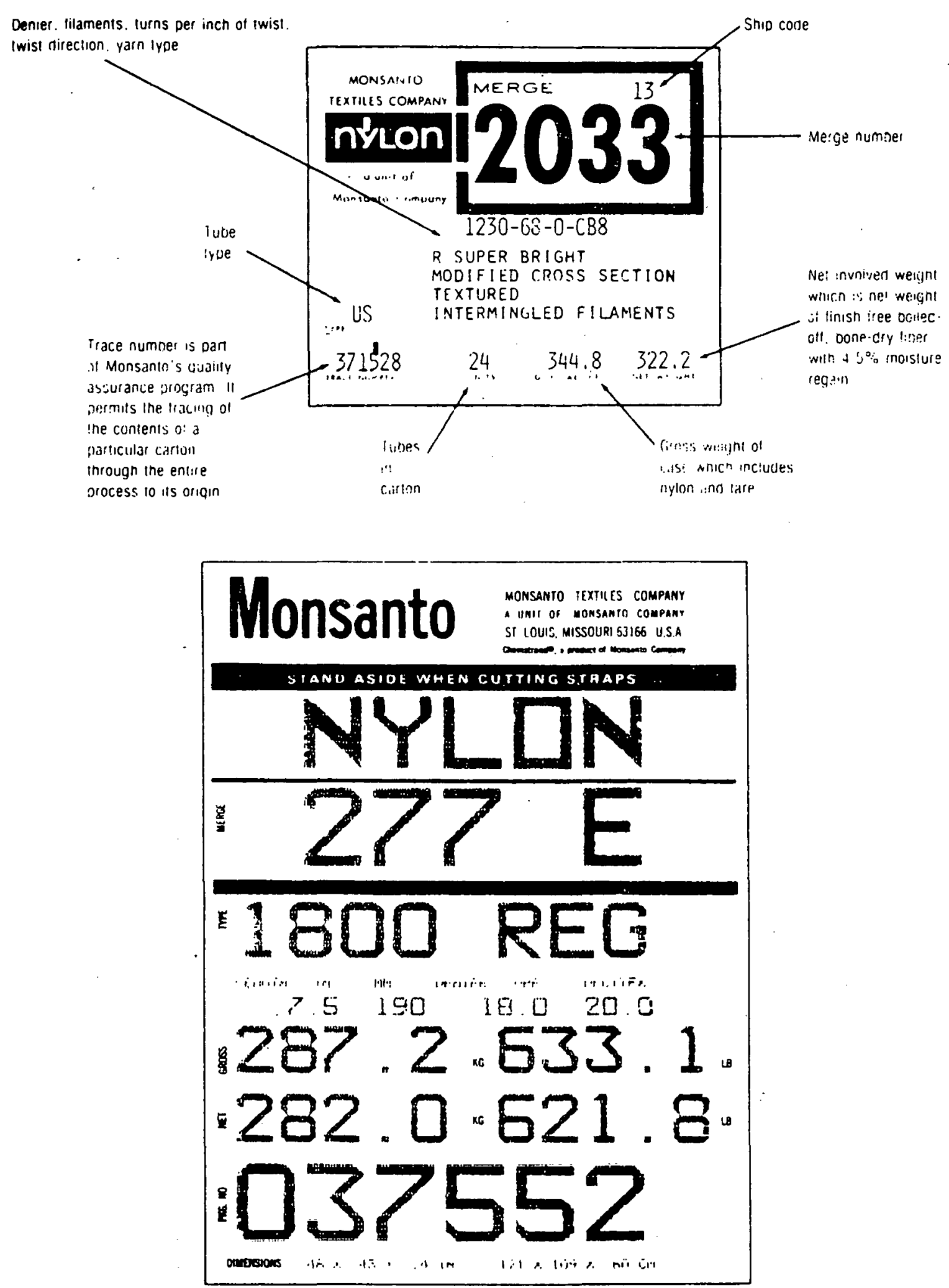
It is evident, then, that the first tier of the textile mill products industry is extremely careful to ensure uniformity in fabrics for apparel and home furnishings. This means that they are severely limited in how much they can use recovered fiber materials, particularly secondary waste. Fiber waste other than reworkable waste invariably consists of a mixture of fiber types that vary widely in chemical composition, filament size, filament length, cross-sectional shape, lustre, dye receptivity, tension history, thermal history, fiber damage, etc. Even assuming that waste fiber can be segregated by generic type (nylon, polyester, cotton, etc.), the variation within each type is still significant and invariably results in yarn differences that yield nonuniform fabrics. For example, in a typical 12-foot-wide carpet with six tufting needles per inch, one defective or different yarn makes 864 yarns oft quality. In a 48-inch-wide fabric with 80 ends per inch, one defective or different yarn makes 3,840 yarns off quality. The economic implications of these simple facts severely limit the possible use of waste fiber in first tier textile mill products.

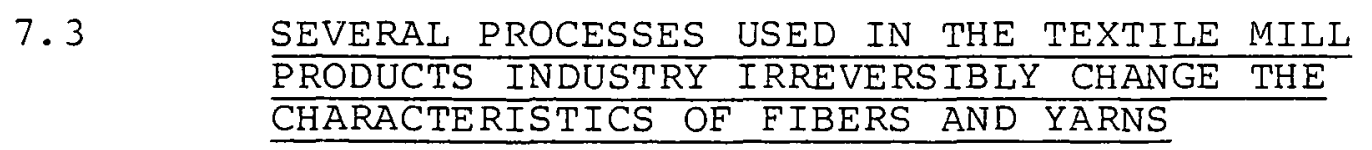

In evaluating the capability of the textile mill products industry to use recovered waste fiber, consideration must be given to the fact that some processes used in textile manufacturing are irreversible. For purposes of this discussion, an irreversible process can be defined as one in which the fiber undergoes a permanent physical, chemical, or structural change, a change that cannot be reversed. In the strictest sense, all textile processes are irreversible, but some processes cause only minor changes in the fiber. In such cases, the fiber can be put through the process again. Processes like this are considered reversible.

\section{3 .1 Spinning and Weaving Operations}

Carding is an example of a reversible process. In carding, individual fibers are physically separated and aligned to form a uniform yarn structure. If clumps of unseparated fiber pass through the card, the resulting yarn has thick areas known as "slubs." During the carding operation, the average length of the fibers is reduced by approximately 5 percent through the mechanical action 
of the card. Thus, a physical change does occur in the carding process, but the change is not large enough to prevent carded fiber from being rerun through the process. The drawing process also does not cause permanent changes in the fiber.

Reworkable waste fiber that has been through only the carding and drawing processes is currently reused in the first tier textile industry. Even though carding and drawing cause minimal changes in the fiber, these changes are significant enough that no more than 5 percent waste fiber is blended with virgin fiber. A larger proportion of waste produces a yarn end that exhibits nonuniformity in a woven or knit fabric. This results in a significantly higher probability of breaking during subsequent processing steps, reducing machine operating efficiency.

Roving and spinning are the first processes that produce irreversible changes in the fiber. In these steps, the fiber bundle is twisted for the first time, and once this happens, fibers can be recovered for reuse in only a few special cases. This is because the mechanical action necessary to separate and align the twisted fiber bundle is so severe that fiber breakage reduces the average length below a level acceptable for reprocessing. Therefore, after fibers become part of a twisted yarn, they generally cannot be processed on currently available textile equipment for first tier products.

One exception to this rule involves some polyester fibers and fibers with very long staple lengths ( 4 to 6 inches), such as wool and some acrylics. Although fiber length is significantly reduced in processing, average length is still great enough to permit processing into textile fabrics. Such fabrics are of lower quality than those produced from virgin fiber. Processing long staple fiber represents only a small part of the fiber consumption in the United States. For example, of the 49,000 cards in use in the united States, only 2,670 (5 percent) process long staple fiber.

A second exception to the rule that spinning is an irreversible step involves a thread production mill that uses longer than average staple length cotton. This mill is believed to be recycling in-house spun yarn waste (reworkable). This waste reuse requires a special piece of equipment to separate the fibers in the yarn. This equipment item is not commercially available, and the waste reuse system is probably limited in applicability to sewing thread manufacture 
involving long-staple cotton. It can be reasonably concluded that after fibers have been twisted into yarn structures, only small and insignificant quantities (less than 1 percent) can be recycled into primary textile fabrics.

Recovering usable fiber is further complicated when yarns are interlaced into woven and knit fabrics. The process of separating individual fibers from the entangled mass and aligning them invariably results in a drastic reduction in average fiber length. Some fiber for second tier end uses (furniture stuffing, felted pads, nonwoven inner linings, etc.) is recovered from waste fabrics (rags) by a process known as garnetting. In this process, the fabric is tightly held between two grooved rollers and ripped into small pieces by a rotating cylinder with large metal teeth. This process has been used to produce a small quantity of wool fiber for second tier fabric use, but recycling of fiber from woven fabric on any reasonable scale is beyond the current state of the art. In summary, by the time fibers have been processed into fabric form, they have become so entangled that removing them for reprocessing invariably causes irreversible damage to the physical structure of the fibers.

\subsubsection{Preparation, Dyeing and Finishing Operations}

In the preparation, dyeing, and finishing of textiles, broadly termed wet processing, there are a number of points where irreversible chemical and physical changes take place in the polymer/fiber sy3tem. The subprocesses Lhat make up the overal1 wet processiny sector of the textile mill products industry are discussed in the following paragraphs.

\subsubsection{Sizing-Desizing}

A plastic film, termed "size", is applied to textilewarped yarns before they are woven. The size temporarily strengthens the yarn and reduces abraison as the warp yarn is passed througli the warp by the shuttle during the weaving process. The main lliterials used for sizes are starch (a natural polymer), polyvinyl alcohol (a synthetic polymer), carboxymethyl cellulose (a cellulose derivative), or some blend of the three. After the fabric is woven and enters a wet processing phase, the bulk of the size is removed in dcsizing. Desizing uses enzymatic action to 
remove starch and hot water to remove polyvinyl alcohol and carboxymethyl cellulose. The desizing process is not totaliy efficient, however, and some residual size is always left in the fiber.

Research indicates that under the best conditions, only about 85 percent of the polyvinyl alcohol is removed in desizing. An additional 10 percent is removed during bleaching, leaving about 5 percent in the fiber. The fiber becomes a type of composite, consisting of fiber polymer and size polymer.

Fabric that is sized and desized ultimately possesses its own distinctive mass and type of residual size. The residual size can affect the dyeing behavior of the fiber; size interferes with dye uptake and penetration. Furthermore, the fibers must be easily and completely wettable; otherwise, results will be uneven in subsequent wet processing. If all fibers are sized and desized in a single plant and in a uniform manner, the residual size in the fabric prior to dyeing will also be uniform. Therefore, the residual size will also be uniform and will not prevent the obtaining of first tier quality goods. on the other hand, fibers from a variety of sources in a recovered materials operation will contain both different size materials and different levels of residual size. Both factors will cause different dyeing and wetting behavior for the individual fibers, thus giving a variable dye uptake and causing uneven dyeing.

\subsubsection{Singeing}

To give a smooth appareance to fabrics produced from staple yarns, fabrics from the loom are singed. In this process, protruding short fibers are burned away with a gas flame without damage to the cloth itself. Since the cloth is not damaged either chemically or physicully, singeing is not considered an irreversible process.

\subsubsection{Scouring}

Scouriny is ncossary to remove impurities from natural fibers. These impurities include natural tats dild waxce, insect parts, woody matter, etc. The main chemical for cotton scouring is sodium hydroxide used at a concentration of 4 grams per liter of mixture, and applied with a surface active agent. Process temperatures are near or above 
boiling, and, although the caustic solution is fairly weak, it is alkaline and some degradation of cellulose always occurs in an alkaline solution. The solution reacts with the cellulose in two distinct ways:

In the absence of oxygen, the reducing ends of the cellulose chains are transformed. The terminal residues that stabilize the alkaline degradation ceases on residue formation; thus, the overall molecular weight of the cellulose is not decreased to any appreciable extent on the alkali attack in the absence of oxygen and properties are not measurably affected.

In llie presence of oxygen, alkali degradation of cellulose during scouring can be severe. Chain scission (break) results during the oxygen/ alkali degradation, giving a corresponding draw-up in mechanical propcrties of the fibers. 'l'he properties of a fiber polymer (strength and dyeability) are extremely dependent on molecular weight. A slight decrease in molecular weight due to auto-oxidative chain scission causes a considerable loss in fiber strength in the critical portion of the property-versusmolecular-weight curve and also affects the uptake of dyestuffs.

Alkali scouring of this kind results in irreversible damage to the polymer structure. The degree of damage greatly depends on the cunditions of scouring; therefore, mixtures of fibers from different plants would exhibit different derrees of deyradation. Because scouring is required of yarns produced in reprocessed fiber mixtures, further degradation occurs, resulting in further loss of polymer properties.

Wool is especially sensitive to alkaline attack during scouring. A weaker base is used in wool in (a polymer backbone unit), causing a reduction in the dry string. Use of a mixture of scoured wool fibers from different sources is inadvisable for reasons already given in the discussion of scoured cotton. 


\subsubsection{Bleaching}

In bleaching natural colorents are removed from fibers. The bleaching material attacks the conjugated chromophores (light-absorbing species) and other polymers in the yarn and fabric. These attacks break the conjugated sequence, and thus shift the absorbents out of the visible spectrum, causing the yarn or fabric to be white or bleached. Treating cellulose fibers with oxydizing agents leads to chemical attack, polymer chain breakage, and an ultimate loss in tensile strength. Hydrogen peroxide and sodium hyperchlorite, both widely used as textile bleaching agents, attack the fiber proper at the same time the conjugated chromophores are being destroyed. To obtain a bleached fiber of satisfactory shrink, oxidation control is critical. The objective is to destroy color matter with minimal damage to the remaining portions of the cellulose fiber.

These products of oxidation of cellulose are called oxycelluloses. Due to the chemical nature of cellulose, the possible points of chemical attack are numerous. Thus, the level of degradation for any batch of bleached fiber is highly dependent on the conditions encountered in the plant (time of exposure, temperature, type and concentration of the bleaching agent, etc.).

Bleached fibers that are derived from various sources will, therefore, vary in tensile strength due to differences in bleaching conditions from plant to plant. In addition, since the chemical points of attack are numerous, exposing the mixture of fibers to a second bleaching operation would initiate a new round of oxidative degradation, further weakening the fiber. Fibers would, therefore, have weaker structures each time the material was put through the bleaching process.

\subsubsection{Mercerization}

Fabrics that contain cotton and that are to be used for apparel and sheeting are often treated continuously during preparation with a concentrated (15 to 20 percent by weight) sodium hydroxide solution. This is a process known as "mercerization"; it involves impregnating the open width fabric with caustic solution, allowing it to soak in the solution, and following this with a second alkaline dip. The process is completed by stretching the fabric with a tenterframe and passing it under a series of hot water sprays to wash out the caustic soda. 
In an alternate, but related process, cotton yarns or fabrics are mercerized without tension. The process called "slack mercerization," gives the material considerable elasticity. The elastic cellulose material is used principally in white bandages, with a small amount going into casual wear skirts, boat covers, etc. Stretchmercerized material is dyed in much greater quantities than is slack-mercerized material.

Cotton fibers swell laterally and shrink longitudinally during mercerization, causing radical changes in fabric properties. As indicated in Figure 7-2, the final fiber properties depend on the concentration of sodium hydroxide used. In the optimum concentralion range, the following changes take place:

- The fiber shrinks.

- Extensibility decreases.

- The breaking strength actually increases slightly.

- The degree of lustre increases.

The increase in strength is especially interesting. Cellulose impregnated with sodium hydroxide and exposed to air undergoes chemical degradation; and, under normal circumstances, a decrease in strength would be expected. In mercerization, a physical transformation takes place, however, that affects any inss of strength duc to chemical deqradation. Sodium hydroxide constitutes a small enough molecule that complete penetration of the oryctaline regions of the cellulose takes place. The majority of the oclluloxc hylroxyl yıuups dre converted into the sodium salt during the impregnation phase of mercerization, forming alkali-cellulose nr snda-rellulose. Whon the caustic soda is removed by hack-hydrolysis with hot water rinse, cellulose is regenerated, but the crystalline structure of the polymer is altered. The new structure, termed "cellulose II," has different unit cell dimensions in $x-r a y$ crystalline analysis from the native fiber, cellulose I. (sep Table 7-8). The pyranose rings are rotated in cellulose II, accounting for crystalline differences that directly affect its properties, including strength. 
FIGURE 7-2

Liependence of the Properties of Mercerized

Egyptian Cotton Fibers Upon the

Concentration of Sodium Hydroxide

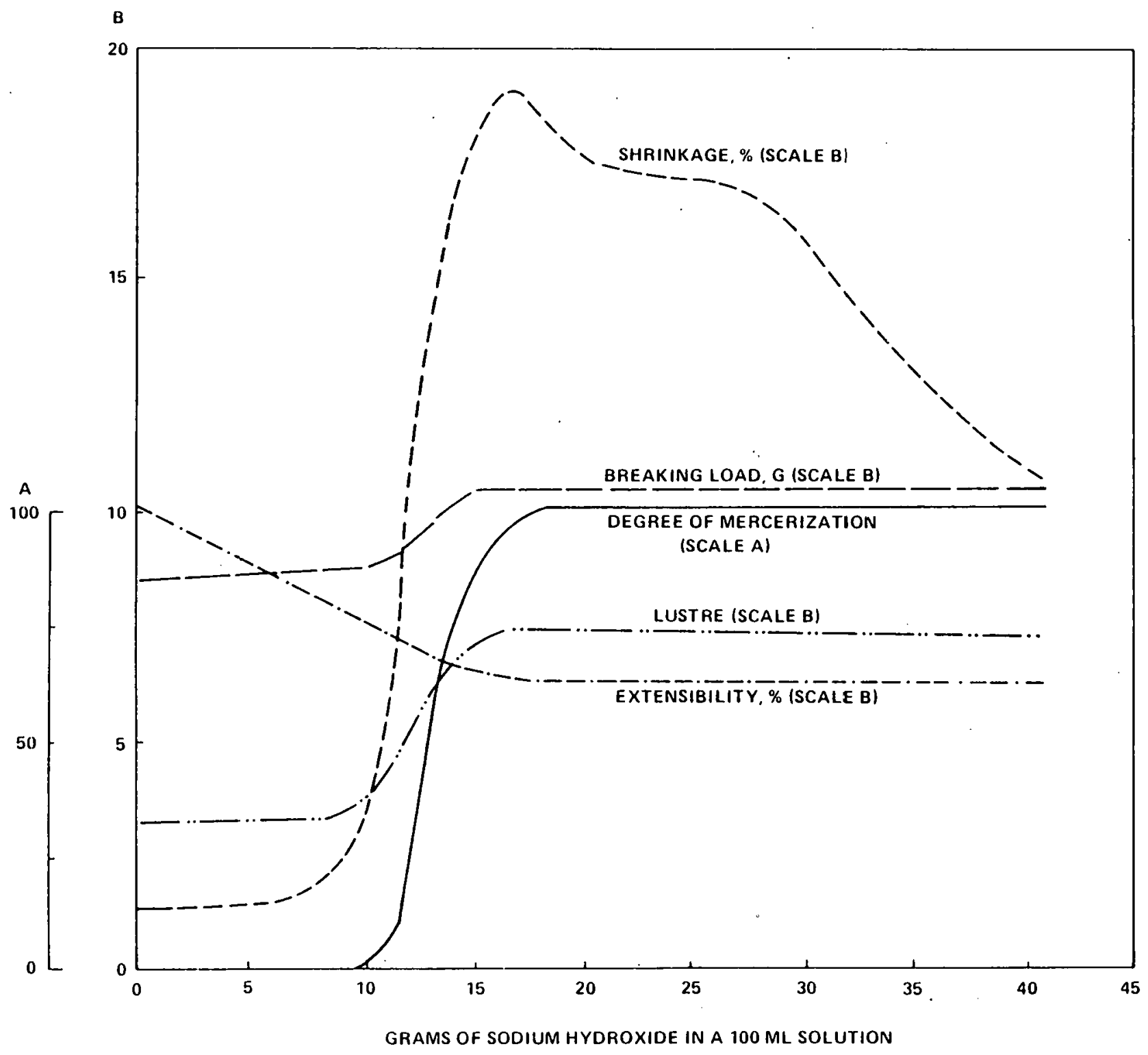


TABLE 7-8

Change in $\mathrm{X}$-Ray Unit cell structure on Mercerization of Cellulose

\begin{tabular}{|c|c|c|c|c|}
\hline \multirow{2}{*}{ FIBER } & \multicolumn{2}{|c|}{ UNIT CELL DIMENSION, (A) } & \multirow{2}{*}{$\begin{array}{c}\text { A/C ANGLE } \\
\text { (DEGRES) }\end{array}$} \\
\cline { 2 - 4 } & $\mathrm{A}$ & $\mathrm{B}$ & $\mathrm{C}$ & \\
\hline $\begin{array}{c}\text { CELLULOSE I } \\
\text { (NATURAL) }\end{array}$ & 8.35 & 10.3 & 7.9 & 84 \\
$\begin{array}{c}\text { CELLULOSE II } \\
\text { (MERCERIZED) }\end{array}$ & 8.1 & 10.3 & 9.1 & 62 \\
\hline
\end{tabular}


Table 7-9 indicates the crystalline cellulose content of various materials. Mercerized samples have approximately 10 to 20 percent less cellulose than native cotton does. The strengthening effect of mercerization can be seen more clearly in Table 7-10.

The most important property changes resulting from mercerization are increases in water uptake and dye affinity. Untreated cotton has about a 40 percent water accessibility factor, while mercerized cotton reaches 70 percent on the same kind of test. Figure 7-3 compares the absorption by mercerized and scoured-only cottons.

Water is the diffusing agent for dyes and chemicals; it enables them to penetrate the fiber and makes chemical treatment possible. Not surprisingly, mercerizing cellulosic fibers increase their absorption of dyes, metal hydroxides, and finishes and raises their rates of hydrolysis and oxidation. Table 7-ll gives the effect of tension in mercerization on the absorption of two common dyes. Slackand tension-mercerized cottons absorb approximately twice as much dye as the unmercerized standard. The rate of dyeing is also affected by mercerization. The process reduces the time of half absorption by approximately 75 percent, as shown in Table 7-12. The shade of mercerized cotton is also. more intense because the almost-cylindrical mercerized fibers scatter less light than do the thin, ribbon-shaped native cotton fibers. The mercerized cotton absorbs finishing chemicals more readily than the unmercerized fabric does, the change here being roughly comparable to the situation with dyes.

It seems, then, that the property modifications stemming from mercerization depend on process variables, such as concentration of sodium hydroxide, tension on the fiber, the degree of hot water washing, etc. Each textile plant has varying mercerization conditions, and fibers from different plants will thus have widely varying chemical absorption properties. A mixture of mercerized ana unmercerized cotton fibers would differ even more in such properties. If such a fiber mixture were woven into a fabric and dyed with (for instance) chlorazol sky blue FF, a multi-shade, uneven dyeing would result. Recycling cotton-containing fabrics is not feasible because the fabrics are likely to contain fibers mercerized under different conditions or mercerized fibers mixed ivith unmercerized fibers. In either case, cross variations in dyeing and finishing properties would result, and the product would be unacceptable. 


\section{TABLE 7-9}

Crystalline-Cellulose Content of Various Materials Measured by the Rate of Acid Hydrolysis in an Aqueous Solution of Hydrochloric Acid and Ferric Chloride

\begin{tabular}{|l|c|}
\hline MATERIAL & $\begin{array}{c}\text { CRYSTALLINE } \\
\text { FRACTION } \\
\text { PERCENT }\end{array}$ \\
\hline RAMIE & 95 \\
COTTON & 82.87 \\
COTTON LINTERS & 88 \\
COTTON MERCERIZED UNDER TENSION & 78 \\
COTTON MERCERIZED WITHOUT TENSION & 68 \\
FORTISAN & 83 \\
FIBER G & 81 \\
CORDURA HIGH.TFNACITY RAYON & 62 \\
TEXTILE RAYON & 68 \\
\hline
\end{tabular}


TABLE 7-10

Strenthening Single Yarn by Mercerization

\begin{tabular}{|c|c|c|c|c|}
\hline \multirow{2}{*}{ YARN NUMBER } & \multirow{2}{*}{$\begin{array}{c}\text { TWIST } \\
\text { TURNS } \\
\text { PER INCH }\end{array}$} & \multicolumn{2}{|c|}{$\begin{array}{c}\text { SINGLE-THREAD } \\
\text { STRENGTH, LB. }\end{array}$} & \multirow{2}{*}{$\begin{array}{c}\text { GAIN IN } \\
\text { STRENGTH } \\
\text { PERCENT }\end{array}$} \\
\cline { 2 - 5 } $12 / 1$ & 9 & 0.64 & 1.39 & 117 \\
$12 / 1$ & 14 & 1.46 & 1.70 & 16 \\
\hline
\end{tabular}


FIGURE 7-3

Sorption of Water by Mercerized cotton at $25^{\circ} \mathrm{C}$

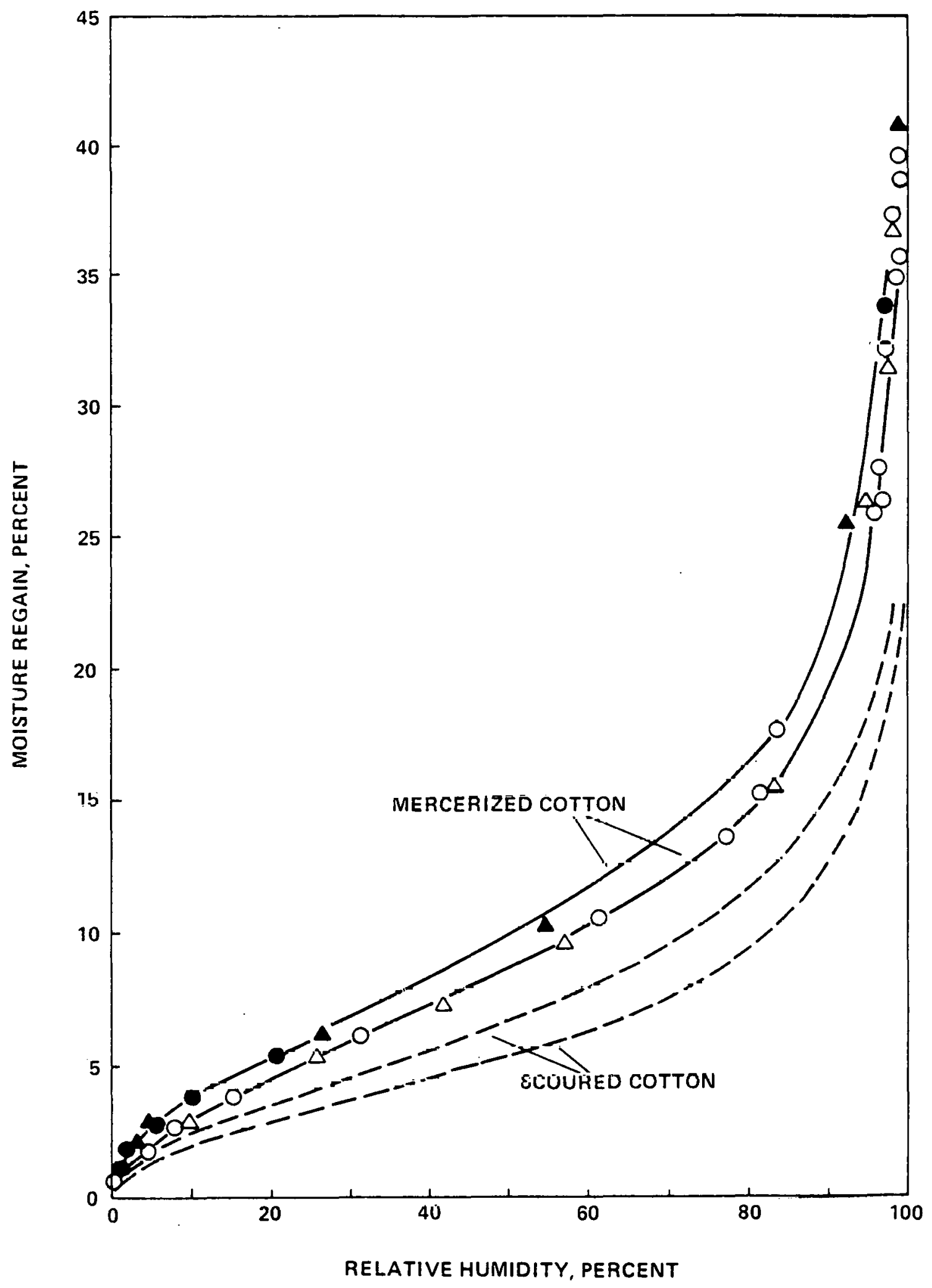


TABLE $7-11$

Effect of Tension in Mercerization on the Adsorption of Benzopurpurine $4 \mathrm{~B}$ and Chlorazol Sky Blue FF

(Hanks Dyed in a Common Bath)

\begin{tabular}{|c|l|c|}
\hline DYE & \multicolumn{1}{|c|}{ TREATMENT } & $\begin{array}{c}\text { DYE ADSORBED } \\
\text { (G/100 G FIBRE) }\end{array}$ \\
\hline BENZOPURPURINE 4 & UNMERCERIZED & 1.5 \\
& MERCERIZED WITH TENSION & 2.9 \\
& MERCERIZED WITHOUT TENSION & 3.5 \\
& & 0.15 \\
CHLORAZOL SKY BLUE FF & UNMERCERIZED & 0.27 \\
& MERCERIZED WITH TENSION & 0.24 \\
\hline
\end{tabular}


TABLE 7-12

Rate of Dyeing

\begin{tabular}{|l|c|}
\hline \multicolumn{1}{|c|}{ FIBER } & $\begin{array}{c}\text { TIME OF } \\
\text { HALF-ADSORPTION } \\
\text { (MINUTES) }\end{array}$ \\
\hline SAKEL COTTON & 1.1 \\
SAKEL, MERCERIZED WITH TENSION & 0.25 \\
AMERICAN COTTON & 1.4 \\
AMERICAN, MERCERIZED WITH TENSION & 0.35 \\
\hline
\end{tabular}




\subsubsection{Dyeing}

The complexity of dyeing is reflected in the fact that all classes of dyes will not color all types of fabrics. Tabie 7-13 lists dye types and gives the fibers for which each has an affinity. Few dyes color more than three to five fiber types satisfactorily, and even within a classification, there are severe differences in the level of coloration obtained. For example, the disperse dyes that are used most often to dye polyester tibers include light to heavy shades. However, only very light shades can be obtained on acrylic fibers with disperse dyes, and thus this class of dyes has Iimited applicability for acrylic fibers such as orlon and acrilan.

Even within a fiber type, such as the generic classification "nylon," slight differences in dyeing behavior persist. There are two dominant subclasses in the main generic class of nylons-six-six and nylon six. Nylon six-six is based on poly-hexamethylene adipamide and nylon six is based on poly-caprolactam. The structures of these two are different in physical characteristics, crystal energy, glass transition temperature, etc. As a result, they dye at different shades under similar conditions. The endgroup content of various commercial nylons influences both the rate of dyeing and the uptake of acid dyes (acid dyes are the most commonly used dyes for nylon). Figure 7-4 shows the relationship between the dye uptake and the group content.

To meet specific end uses, fiber manufacturers often intentionally modify the amine end groups in their standard nylon line by introducing imine, additional amine, or acid functional groups into the structure. Changing the amine end groups yields vastly different shades in a common dye bath. In fact, capping the amine groups with acid groups produces "catonic dyeable" nylon, which has an affinity for basic dyes but not for acid dyes. Such intentional end group modifications result in differential dyeing textile structures, such as regular and deep-dyed tufted carpet.

The effort to obtain controlled multicolor effects has also resulted in modifications to several other goneris fiher types. Usually, acrylics are generically defined as materials containing greater than 85 percent acrylonitrile units in repeat chains. The remaining 15 percent consists of various co-monomers that reduce the crystallenity of the acrylic and provide better dyeing characteristics. The co-monomer that is used to produce a particular dye condition is normally chosen with different 
TABLE 7-13

Types of Dyes used in the Textile Inciustry

and the Fibers to Which They Are Applicable

\begin{tabular}{|c|c|c|c|c|c|c|c|c|c|}
\hline \multirow[b]{2}{*}{ DYE TYPES } & \multicolumn{9}{|c|}{ FIBER TYPES } \\
\hline & ACRYLIC & cotron & WOOL & ACEtate & RAYON & POLYESTER & $\begin{array}{l}\text { POLYESTER/ } \\
\text { COTTON }\end{array}$ & NYLON & $\begin{array}{l}\text { NYLON/ } \\
\text { COTTON }\end{array}$ \\
\hline $\begin{array}{l}\text { ACID } \\
\text { AZOIC } \\
\text { ANILINE BLACK } \\
\text { BASIC ICATIONICI }\end{array}$ & - & ? & - & - & - & 0 & 0 & • & - \\
\hline $\begin{array}{l}\text { DEVELOPED } \\
\text { OYEBLENDS } \\
\text { DIFECT } \\
\text { DISPERSE }\end{array}$ & - & - & & - & $\bullet$ & - & $\begin{array}{l}\bullet \\
\bullet \\
\bullet\end{array}$ & - & - \\
\hline $\begin{array}{l}\text { FIBER-REACTIVE } \\
\text { FLUORESCENT } \\
\text { INOIGO } \\
\text { SULFUR }\end{array}$ & - & $\begin{array}{l}0 \\
0 \\
0\end{array}$ & - & - & • & - & ? & $\stackrel{0}{\circ}$ & • \\
\hline $\begin{array}{l}\text { VATS } \\
\text { NATURAL } \\
\text { OXIOATION BASE } \\
\text { MORDANT } \\
\text { PIGMENTS }\end{array}$ & & ? & - & & $\bullet$ & & $\bullet$ & 0 & - \\
\hline
\end{tabular}


FIGURE 7-4

Relationship Between Dye Uptake and Amine End-Group Content for Various Commercial Dyes

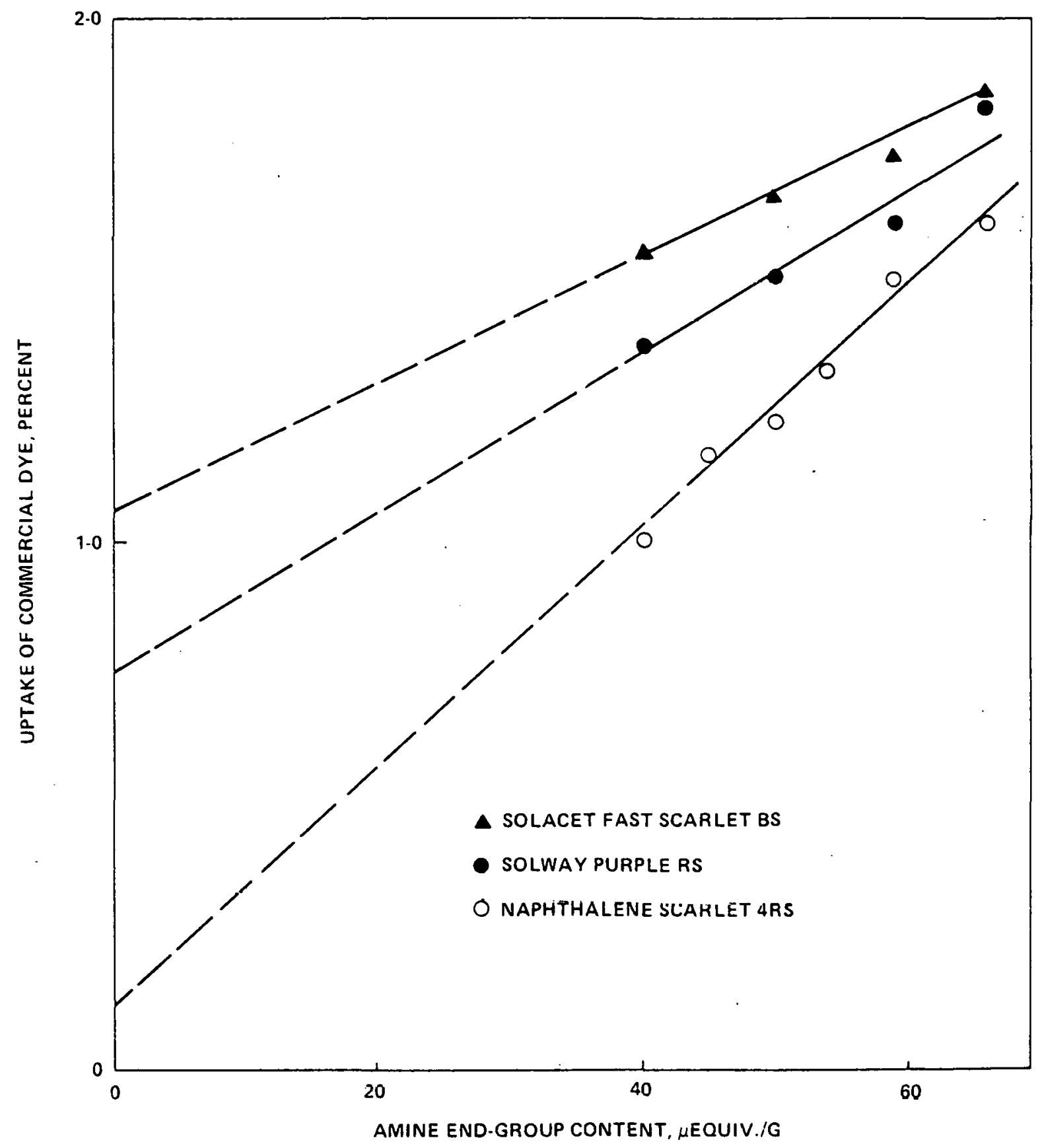


proportions of vinyl acetate, and, when used under different conditions, it gives different shades. The effect of slight modifications to the acrylic structure is such that a mixture of differently controlled fibers would dye quite differently in either acid or basic dye baths.

Polyester fibers are also subject to structural modifications. Two main subgroups within the generic class are dominant: poly (ethylene terephthalate) and poly (dimethylcyclochexane terephthalate). Dupont's Dacron is an example of the first, and Kodel by Eastman is an example of the second. Dyeability is different between these two, with the kodel fiber having a higher second order glass transition temperature. Modifications of the basic homopolyester are accomplished by shortening chains, altering spinning conditions, or introducing co-monomers. Such modified polyesters would exhibit radically different dyeing behavior toward a particular dye class.

Nylon, regular dyeable acrylics, polyesters, and viscose rayons from several manufacturers have different dyeing characteristics. These are due to specific differences in structure, crystallinity, molecular weight, etc. Regular dyeable nylons of Monsanto and Dupont can vary by as much as 11 percent in the amine end group content and thus dye differently in a common dye bath.

Physical treatment of fibers after spinning also affects dyeability. The quantity of dye absorbed on polyester decreases with increased draw ratios and shows a clear minimum absorbency. Absorbency is a function of the temperature of the heat-setting treatment. Dye uptake decreases when dry hoat-sctting lather than steam is used because of oxidation of amine end groups during the hot air process.

In sumilary, then, reuse of a mass of fibers of unknown chemical/physirial makeup and thermal balkgrouna presents two severe dyeing problems. First, different generic fiber classes require diffcrent dye classesor at least different dye concentrations and conditionsto achieve the same shade. Second, even within generic fiber classes manufacturer-specific differences cause different dye absorptions in a common dye bath. Any mixture of fibers, then, will produce a variety of shades when dyed, resulting in randomly colored fabrics. Such fabrics have only a limited appeal in the textile market, the consumer desiring either uniform coloring or controlled effects achieved with multiple shades. 
During end use a number of irreversible chemical and physical changes occur in fibers, causing the loss of useful properties. These changes are usually referred to as "degradation," and in most instances they involve a rupture of primary chemical bonds. The yellowing of cotton, the embrittlement of nylon, and the cracking of rubber are all typical examples of polymer degradation.

Like other polymers, fibers are composed of longchained molecules containing thousands of atoms chemically bonded together. Most of the useful properties of fibers (breaking strength, toughness, etc.) are related to the average length of the polymer chains. If only one bond of the long chain ruptures, the average length of the two fragments is only half the length of the original chain. For example, if one bond in a chain containing a thousand bonds is broken, the extent of degradation would be only 0.1 percent, but the average chain length would be reduced 50 percent and the properties appreciably altered. It is not surprising, therefore, that polymer properties are extremely sensitive to environmental degradation. Some of the types of degradation that come about during the end use of fabrics are briefly discussed in the following paragraphs.

\subsubsection{Mechanical Deterioration}

Fabrics are subject to severe mechanical action during normal wear. The pockets and knees of pants and the cuffs and elbows of shirts and blouses are constantiy subjected to abrasive action. After repeated use of the garment, this abrasive action causes a whitening of color or "frosting" of the fabric. When the fibers from a worn fabric are examined under a microscope, the degradation resulting from mechanical action is immediately apparent. Some fibers in the yarn bundle are broken and the broken ends are exposed. Some fibers have large chunks broken off, and others are ruptured into many fine filaments i.n a type nf degradation called "fibrillation." These mechanical degradation effects are responsible for the whitish appearance of worn fabrics. 


\subsubsection{Photochemical Deterioration}

With the possible exception of acrylics, all of the common textile fibers (cotton, nylon, polyester, polypropylene, rayon, and wool) undergo degradation (a loss in properties) when exposed to sunlight. The degradation severely limits the useful life of polymers and has consequently been the subject of extensive research. Polymer chain cleavage and the subsequent loss of useful properties can be slowed by the use of carefully selected stabilizers, but deterioration cannot be completely prevented. Exposing the fibers to sunlight will inevitably cause a loss of breaking strength, decrease in extensibility, increased brittleness, and vellowing of textile fibers. These are irreversible chemical changes that produce a nsed fiber significantly different from a virgin fiber.

\subsubsection{Chemical Deterioration}

I'extile fibers in use are constantly exposed to oxygen and moisture, and extensive chemical degradation in the fibers result.. Cotton, nylon, and to a lesser extent polyester are all subject to a reaction with water (hydrolysis) which splits the polymer chains. Similarly, oxygen reacts with most synthetic and natural fibers reducing fiber breaking strength and extensibility. During normal use of textile fibers, these chemical reactions cause permanent irreversible changes in fiber structure and properties.

\subsubsection{Biological Deterioration}

Natural fihors are biodogradable aild die dteacked by many forms of life. Bacteria, fungi, and insects are all known to cause degradation of natural fibers. Microorganisms produce enzymes which are capablo of silibling pulymer chains. Discoloration and loss in useful properties accompany biological degradation.

The changes in the chemical/physical structure of fibers that come about during end use are generally irreversible. They cause a loss in useful mechanical properties that greatly limits the possible uses of recovered materials in first tier textile mill products.
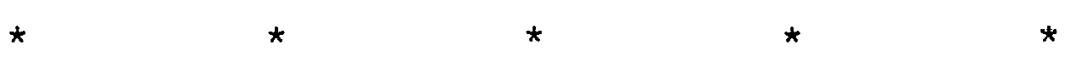
This chapter has discussed several limitations on the use of recovered materials in the textile mill products industry. The following chapter discussed proposed materials recovery targets. 


\section{CHAPTER 7 SOURCES}

1. "Textile Machines in Place," Textile world, vol. 125, no. 4, p. 34,1975 .

2. Textile Industries, issue 10, p. 47, 1974 .

3. E.R. Trottman, Dyeing: A Chemical Technology of Textile Fibers, fifth edition, London, England, 1975.

4. R.H. Peters, Textile Chemistry Two, New York, New York, 1967.

5. D.M. Kates, Tcxtile Chemist and Colorist, vol VII, no. $12,30 / 220,1975$.

6. Conversation with Dr. Wayne Tincher, School of Textile Engineering, Georgia Institute of Technoloqy, 1979.

7. Conversation with Dr. Fred Cook, School of Textile Engineering, Georgia Institute of Technology, 1979.

8. E.I. Valco, Chemical After-Treatment of Textiles, New York, Wiley Inter-Science, 1971.

9. Environmental Protection Agency, Reference Point Source Categories: Textile Milis, Washington, D.C., June 1974 .

10. C.L. Byrd, The Theury of coloration of 'Textrles, Bradford, England, Dyres company publishing Trust, 1975.

11. W.C. Carter, "The Development of Polyesters/Wool Uniform Fabrics with Improved Durability and Appcarance," Final Techrical Repurt, USAF F-3.3615-72-r-1.82?, Goorgia Inetitute nf Technnlngy, August 1975 .

12. W. Lincoln Hawkins, Polymer Stabilization, New York, John Wiley \& Sons, 1972 . 
In the National Energy Conservation and Policy Act (NECPA), * the Department of Energy (DOE) was made responsible for evaluating the textile mill products industry (SIC 22). DOE was also given responsibility for developing materials recovery targets to be achieved progressively by 1987. The targets are for each industry subsector and give the percentages of raw fiber, yarn, and continuous filament input to be composed of by-products generated from recovered materials. Recovered materials for the textile mill products industry are in two categories:

- Primary waste-textile fiber, yarn, and fabric waste generated in the various textile manufacturing operations

- Secondary waste-textile products that have been used for their intended ourpose and discarded as no longer useable.

The targets presented in this report were established, as directed by the Congress, at levels which represent the maximum technically and economically feasible increase in utilization of energy-saving recovered materials that can be achieved by January I, 1987. Because of the limited duration of this study, these targets were not developed to represent the maximum level of energy conservation or the minimum level of energy use in the textile mill products industry. Energy conservation as the consequence of using recovered materials is of interest to DOE but is outside the scope of this study.

Much of the primary waste generated in the textile mill products industry is the separation of fibers into forms suitable for specific textile operations. Essentially all of the wastes generated in the spinning of fibers into yarn for use in the first tier of the industry are utilized in the second tier.

* See Appendix A for relevant sections of this act. 
In defining recovered materials targets for the textile mill products industry, it was decided to set targets for each industry subsector, the subsectors being determined by the 4-digit Standard Industrial Code (SIC) classifications. As mentioned earlier, manufacturing processes and products are so diverse within the industry, that targets for the industry taken as a whole would have absolutely no meaning for an operating plant within the industry. For example, fabrics produced by cotton weaving mills (SIC 2211) are completely different from nonwoven fabrics (SIC 2297) in required characteristics, technical processes, and raw material input, and this is true throughout the industry. There are even many different processes and product requirements within a 4-aigit SIC classification, hut detailcd informatiun un a plant-by-plant basis could not be gathered in the limited time available ful Lliis study. Thorefore, the 4-digit categories were chosen for establishing proposed targets. The following paragraphs show how the proposed targets were determined.

8.1

IN ORDER TO SET TARGETS, CURRENT RECYCLING LEVELS WERE CALCULATED, AND PROJECTIONS WERE MADE TO 1987

To properly evaluate proposed recovered materials targets for the textile mill products industry, it was first necessary to determine the current flow of materials through the various subsectors and processes within the industry. This was accomplished, as required by the NECPA, through direct contact with the major firms affected and with other firms that influence the use of materials within the insinstry. The various trade associations previously listed were also contacted, as were research personnel at the followilly institutions:

Clemson University, School of Textile Engineeriritj

Georgia Institute of Technology, School of Textile Engineering

Instilutc of I'extile Technology

North Carolina State University, School, of Textile Engineering. 
These sources and the considerable amount of literature published on the textile mill products industry were used to obtain information on the following subjects:

- Current raw material (natural fiber, man-made fiber, man-made filament) flow through the textile mill products industry

- Current use of primary and secondary waste in the industry

- Technologies currently available and anticipated that will affect the use of recovered materials between now and 1987

- Government policies and regulations that may affect the use of recovered materials in the industry

Economic and financial conditions in the industry that could influence decisions by company management on the reuse of recovered materials.

This information was then analyzed to project the use of recovered materials by the industry to 1987 .

Table 8-1 shows the current pounds processed through each 4-digit SIC subsector of the industry during 1978. These data are the best available for each subsector. Basic data were acquired from the 1972 Annual Survey of Manufacturers prepared by the Bureau of the Census, Department of Commerce. However, individual subsectors were updated to current status whenever possible. In 1972 total fiber consumption was 11.648 billion pounds, and in 1978 it was 12.558 billion pounds. All of the subsectors for which updated levels could not be found were therefore increased by the ratio of $12.558 / 11.648$ to obtain approximations of 1978 values. Sources within the industry indicated that this is reasonable because most sectors grow at the same rate as the industry in general. 
TABLE 8-1

Processed Materials Use in the Textile Mill Products Industry

\begin{tabular}{|c|c|c|c|}
\hline \multirow{2}{*}{ Sic } & \multirow{2}{*}{ INDUSTRY SUBOIVISION } & \multicolumn{2}{|c|}{ PROCESSED MATERIAL } \\
\hline & & $\begin{array}{l}\text { MILLION } \\
\text { POUNDS }\end{array}$ & $\begin{array}{l}\text { PERCENT } \\
\text { OF TOTAL }\end{array}$ \\
\hline 2211 & BROAD WOVEN FABRIC MILLS, COTTON & $2,587.8$ & 16.6 \\
\hline 2221 & $\begin{array}{l}\text { BROAD WOVEN FABRIC MILLS, } \\
\text { MAN-MADE FIBER \& SILK }\end{array}$ & 2.717 .5 & 17.5 \\
\hline 2231 & BROAD WOVEN FABRIC MILLS, WOOL & 178.9 & 1.1 \\
\hline 2241 & NARROW FABRICS, COTTON, WOOL, SILK \& MAN-MADE & 194.3 & 1.2 \\
\hline 2251 & WOMEN'S FULL LENGTH \& KNEE LENGTH'HOSIERY & 89.8 & 0.6 \\
\hline 2252 & OTHER HOSIERY & 120.4 & 0.8 \\
\hline 2253 & KNIT OUTERWEAR MILLS & 315.7 & 2.0 \\
\hline 2254 & KNIT UNDERWEAR MILLS & 147.5 & 0.9 \\
\hline 2257 & CIRCULAR KNIT FABRIC MILLS & 1.094 .5 & 7.0 \\
\hline 2258 & WARP KNIT FABRIC MILLS & 496.9 & 3.2 \\
\hline 2259 & KNITTING MILLS, N.E.C. & 7.7 & 0.0 \\
\hline 2261 & BROAO WOVEN FABRIC FINISHERS, COTTON & N/A & N/A \\
\hline 2262 & BROAD WOVEN FABRIC FINISHERS, SILK \& MAN-MADE & N/A & N/A \\
\hline 2269 & TEXTILE FINISHERS, N.E.C. & N/A & N/A \\
\hline 2271 & WOVEN CARPETS \& RUGS & 83.1 & 0.5 \\
\hline 2272 & TUFTED CARPETS \& RUGS & $1,306.7$ & 8.4 \\
\hline 2279 & CARPETS \& RUGS, N.E.C. & 41.6 & 0.3 \\
\hline 2281 & $\begin{array}{l}\text { YARN SPINNING MILLS, } \\
\text { COTTON, SILK, MAN-MADE FIBERS }\end{array}$ & $2,706.1$ & 17.3 \\
\hline 2282 & YARN TEXTURIZING, COTTON, SILK, MAN-MADE FIBER & 891.6 & 5.7 \\
\hline 2283 & YARN MILLS, WOOI. & 123.9 & 0.8 \\
\hline 2284 & THIEAD MILL3 & 139.2 & 0.9 \\
\hline 2.291 & $\begin{array}{l}\text { FELT GQODE. } \\
\text { EXCEPT WOVEN FELTS \& HATS }\end{array}$ & 58.5 & 0.4 \\
\hline 2292 & LACE GOODS & 5.0 & 0.0 \\
\hline 2293 & PADDING \& UPHOLSTERY FILLING & 330.0 & 2.1 \\
\hline 2295 & COATRD TAMRIS.A, NOT RIJBBERIZED & iJli.2 & 0.9 \\
\hline 2296 & TIRE CORD \& FABRIC & 741.1 & 4.8 \\
\hline 2297 & NON-WOVEN FABRICS & 641.0 & 4.1 \\
\hline 2298 & CORDAGE \& TWINE & 95.2 & 0.6 \\
\hline 2299 & TEXTILE GOODS, N.E.C. & - & - \\
\hline
\end{tabular}


The processed material data in Table 8-1 should not be confused with total fiber consumption data. The data presented are the number of pounds processed through each subsector, but a given fiber may actually be processed several times in different subsectors. For example, a man-made filament could be texturized in SIC 2282, woven in SIC 2221, and any.waste generated could be processed in SIC 2294 before being used in a second tier subsector such as SIC 2293. In this analysis, the desired information is the total amount of material processed by each subsector.

For subsectors in which nonzero targets are proposed, current levels of processed material and processed waste were determined (see Table 8-2). These current levels were then projected to 1987 using the best available data on industry and individual subsector growth. From these projected levels, it was possible to calculate percentages of total material expected to be provided by recovered materials (see Table 8-2). These percentages were considered a preliminary level of materials recovery. Qualitative judgements were then made about the effect of other factors, such as the following:

- Anticipated new technologies that could affect the use of recovered materials by 1987

- Anticipated changes in the intermediate and final markets that could affect the use of recovered materials

- Activities and policies that may be undertaken by the industry and by state, federal, and local governments to increase the use of recovered materials.

The preliminary levels were adjusted to allow for the effects of these factors. The basis for the development of each of the targets is discussed in the next section. 
TAELE 8-2

Current and Projected Levels of llaste

in Subsectors Hith Proposed Nonzero Targets

\begin{tabular}{|c|c|c|c|c|c|c|c|}
\hline \multirow[b]{2}{*}{ sic } & \multirow[b]{2}{*}{ INDUSTRY SUBDIVSION } & \multicolumn{3}{|c|}{1978 PROCESSED MATERIAL } & \multicolumn{3}{|c|}{ PROJECTED 1987 PROCESSED MATERIAL } \\
\hline & & TOTAL & $\begin{array}{l}\text { WASTE } \\
\text { GMILLION } \\
\text { POUNDS) } \\
\end{array}$ & $\begin{array}{c}\text { PERCENT } \\
\text { OF } \\
\text { TOTAL } \\
\end{array}$ & $\begin{array}{c}\text { TOTAL } \\
\text { (MILLION } \\
\text { POUNDS) } \\
\end{array}$ & $\begin{array}{l}\text { WASTE } \\
\text { (MILLION } \\
\text { POUNDS) } \\
\end{array}$ & $\begin{array}{c}\text { PERCENT } \\
\text { OF } \\
\text { TOTAL } \\
\end{array}$ \\
\hline 2231 & BROAO WOVEN FA3RIC MILLS, WOAL & 178.9 & 23.3 & 13 & 178.9 & 23.3 & 13 \\
\hline 2283 & YARN MILLS, WOOL & 123.9 & 16.1 & 13 & 123.9 & 16.1 & 13 \\
\hline 2291 & FELT GOOCS, EXCEPT WJVEM FELTS \& HATS & 58.5 & 34.6 & 59 & $? 6.3$ & 61.0 & 80 \\
\hline 2293 & P.ADDIVG \& UPHOLOTEF Y FILLING & 330.0 & 307.6 & 93 & 430.6 & 401.3 & 93 \\
\hline 2294 & PROCESSED WASTE \& R $\equiv C O V E R E D F I B E F S \&$ FLOCK & 350.0 & 350.0 & 100 & 456.7 & 456.7 & 100 \\
\hline 2297 & NONWOVEN FABRICS & 641.0 & 109.0 & 17 & 1161.5 & 165.2 & 15 \\
\hline 2298 & CORDAGE \& TWINE & 95.2 & 20.9 & 22 & 124.2 & 27.3 & 22 \\
\hline
\end{tabular}


Analysis of material flows through the textile mill products industry indicates that most primary waste generated is used by the second tier of the industry for lower quality products (furniture padding, felting, nonwovens, etc.). Only a relatively small amount of secondary (post-consumer) waste is reused, primarily because there is no established infrastructure other than charitable organizations that collect this waste. An infrastructure has never developed because the cost of collecting, transporting, and preprocessing the material makes the resulting products too expensive for use in the second tier of the textile mill products industry.

One indication that waste is currently being used effectively in the textile mill products industry is the fact that a textile waste industry (SIC 2294) already exists. This industry is composed of many waste dealers who buy, process, broker, and sell textile wastes from the textile mills and apparel factories (SIC 23). Most of these dealers have relatively small businesses operating in limited geographic areas. Smaller firms may just broker the waste, haul it, or buy and sell it; whereas the larger firms buy, separate, inspect, grade, and blend the waste; open and pick it; chop it into short fibers (shoddy); and bale it for use in the second tier of the industry.

The economics of waste handling force companies to be locally oriented. For example, virgin fibers that cost a firm 60 cents per pound are sold to the second tier companies for 8 to 10 cents per pound. At this low price level., waste dealers and textile companies must operate on a thin margin in selling waste. This makes hauling textile wastes over long distances prohibitively expensive. As a result, much apparel industry (SIC 23) waste is not used; the apparel factories (in New York City) being too remote from the second tier textile facilities in the southeast. The general concentration of the textile mill products industry in the southeast prevents transportation from being a problem for primary waste. 
Primary waste generated in the textile mill products industry is estimated to total from 800 million to 1 billion pounds per year. Of this, about 350 million pounds are processed through the existing waste processing industry (SIC 2294); about $100 \mathrm{million}$ pounds ( 0.7 percent) are unfit for waste reprocessing and are dumped in landfills; and the remainder is sold directly from one company to a nother.

Most waste generation in the textile mill products industry actually consists of separating raw material to obtain products of high enough quality for individual textile processes in the industry. The first tier of the industry produces combcr noil and wool noil waste, because the short fibers do not give the quality required for combed cotton or worsted wool products. However, comber noils are often added back into other spinning processes as reworkable waste to give body and surface variation to the yarn and subsequent fabric. Wool noils are also used for this purpose and as cheapeners in wool apparel and other wool products. The actual waste generated by the industry consists of unfit fiber waste that is discarded (about 0.7 percent of total fiber consumption) and process ends that are generated during start-up, shut-down, and misoperation of various textile processes.

Primary wastes are entirely consumed ill the second tier of the industry, and the textile waste industry exists to move wastes to those that can use it. One major textile mill products company uses no non-reworkable waste because it has no second tier operations. It sells all of its waste products to waste dealers or directly to other firms. Conversely, annther major firm sells no waste products; it processes them, instead, in the manufacture of industrial wiping rags. A third firm owns a waste reprocessing company that processes the firm's waste as well as waste purchased from other companies, and sells it to second tier industries.

The economics of waste processing, primarily the capital cost of equipment and the large volume of waste that must be handled to reduce unit costs, make it infeasible for each plant to process its own waste; therefore, specialization in waste reprocessing is common. However, the waste 
reprocessing industry is currently under pressure from several sources and its economic survival is threatened. The most critical threat is posed by the OSHA cotton dust standard, with its requirements for massive capital expenditures. The effect on the waste processors is particularly severe because of the characteristics of the raw material and the regulation will likely force many of them out of business.

The waste reprocessing industry will also be affected by the following changes:

- Increasing use of open-end spinning, which reduces the generation of primary waste

- Tendency of larger textile companies to sell waste directly to other end users

- Increasing use of blended fibers, which makes the reprocessing of waste more difficult and less profitable.

Another factor affecting the use of recovered materials in the textile mill products industry has to do with spinning and veaving processes. These are continuous, hiyiispeeu processes and a company's profits (which average only 2 percent of revenue) depend on efficient operation. Machines are monitored daily, records are kept on each machine, and maintenance programs are extensive to ensure reliability of operation The spinning processes (carding, drawing, roving, etc.) are set for the proper length fibers; therefore the introduction of shorter or reworked fibers, an attempt made on several occasions, has resulted. in increased ends-downs (roving breaks) and the necessity to cease operations. In addition to product quality, this is one of the major reasons for removing the shorter fibers, broken yarns, etc., which compose most primary textile waste. 
The factors discussed thus far are quite general and affect the use of recovered materials throughout the textile mill products industry. More specific factors affect each of the industry subsectors. Some of these specific factors are discussed in the following paragraphs which also give the basis for the specific proposed targets.

8.2.1 The First Tier of the Textile Mill Products Industry (SICs 2211 through 2284, except 2231 and 2283; SICs 2292 and 2295)

The proposed targets for the subsectors composing the first tier of the textile mill products industry are zero percent of raw fiber and yarn input to be satisfied by recovered materials. It is not technically or operationally feasible to use recycled material to produce first tier textile products (apparel fabric, sheeting, toweling, carpeting, etc.) that are acceptable to U.S. consumers. There are also no technologies foreseen that will be available to the industry by 1987 that will allow the industry to make acceptable first tier quality products using recycled materials.

The textile mill products industry sells its goods to intermediate consumers (apparel industry, retail chains and outlets) and final consumers (individual rustomers). Cunsumers in both groups impose stringent requirements on the industry's products. Their requirements cover such characteristics as the following:

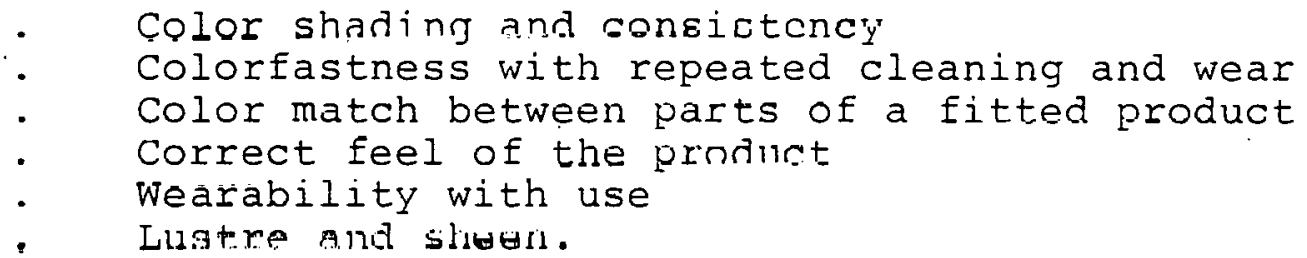

Consumer requirements touch on many similar points as well. All of these requirements can be satisfied only if the correct properties are provided by the basic fiber and 
yarn woven or knitted into the product. Undesirable fibers must be removed and the type or blend of fibers must be precisely controlled. In several steps of the textile process, irreversible properties are imparted to the fibers, yarn, and fabric. These steps are necessary to give characteristics and properties required of the final product, and no way is known for reversing the process in later steps.

Color and color shading are tremendously important to the final consumer and are also the largest single reasons for apparel industry claims for reimbursement against the textile mill products industry. Coloring is so critical and depends on so many factors that constant testing is necessary to keep quality at a minimum level. Much of this testing involves actually dyeing woven goods and checking the results against a master. To a great extent, the final color depends on the basic fibers and yarn used in the fabric; this is particularly true with man-made fibers. In recognition of this situation, man-made fibers are sold by merge number; the merge number certifies that absolutely nothing has changed, including the batch of resin used in making the fiber. Most textile mills try to purchase an entire run by merge number and deliberately mix subsequent deliveries (or lots) of the same merge in an effort to maintain consistency. In some cases, lot numbers in a mill are dyed with a removable color so that their movement can be tracked through the spinning and weaving processes. After they are dyed, the products are constantly checked against master color swatches to ensure consistency. Those that do not conform are downgraded to seconds and sold to the second tier market.

The basic causes of shade and color differences in fabric are differences in yarn dyeability. Different types of fibers have different affinities for a given dye. Dyes for acrylic fibers are completely different from those used for polyester nr cotton. In fact, different types of polyester or acrylic also dye differently. A yarn made of shorter fibers gives a different shade (because of light reflectance and absorption) than the same yarn does made with only long fibers. Thus, if a fabric is to be dyed and the results are to be consistent, it is imperative to know the precise composition of the yarn by fiber type, lot number, merge number, and type of preprocessing. 
The demand for secondary or post-consumer waste declined rapidly with the advent of man-made fibers. These fibers had many new desirable characteristics (permanent press, integrated colors, stretchability, wash and wear, etc.) that could be obtained by blending various mixes of man-made fibers and natural fibers. As a result, almost all textile products today contain various blends of these fibers. These blends vary from product to product and company to company, and, although the Textile Labeling Law requires labeling as to fiber content, the figure given is only nominal and does not indicate precise content. This blending of fibers makes secondary waste unusable for the first tier market and is the main reason why secondary waste is ignored as a source of recovered material.

Given the problems described here, it was concluded that U.S. textile produrts from the firet ticr of the industry would inevitably lose out to foreign products if the use of recovered materials were made mandatory. Therefore, the proposed target for those subsectors producing first tier products was set at zero (zero percent recovered materials to be used in fiber and yarn input).

8.2.2 Broadwoven Wool Fabric and Yarn Mills (SICs 2231 and 2283)

There are two types of mills in the woolen subsectors of the industry - worsted mills and woolen mills. The worsted mills spin yarn and weave fabrics used primarily ill llen's sults. 'l'hese tabrics must be lightweight and compact. (Women's apparel fabric is usually quite different; it generally has an irregular surface and is bulky and fluffy.)

In the worsted wool fabric mills, the wool is combed in much the way combed cotton is, to remove the shorter fibers. Because of their increased ends per pnind, thesa tibers increase the bulkiness and thickness of the yarn. (These shorter fibers are termed "wool noils.") The resulting yarn is much thinner, and the fabric j.t is used in is also much thinner and has fewer fibers protruding from its surface.

Wool noils are perfectly good wool fiber, and they are eagerly purchased by makers of woolen fabric for women's garments, blankets, wool coats, etc. The noils increase bulkiness and insulating capability while still reducing the average price of a given yard of woolen fabric (since they are considerably cheaper than raw wool). 
Wool fabric is long and generally very loosely woven; therefore, it can be unwoven to obtain useful wool fibers. This is currently done in Europe, primarily in Italy; and much of the material that is unspun is from U.s. secondary waste goods. After being unspun, the wool fibers are made into consumer products that are sometimes shipped into the United States.

The unspinning operation was discontinued in the United States when the Wool Labeling Act was passed requiring U.S. goods to be labeled "used wool." (The foreign goods carry only the label "all wool.") Customer resistance to goods labeled "used wool" plus the changing apparel market in the United States resulted in the current unsatisfactory position the wool industry currently has in the United States, where only about 2 percent of all processed material is wool.

Wool noils currently are about 13 percent of the material input, and that percentage is unlikely to change between now and 1987. With the wool Labeling Act and the continued growth in popularity of man-made fibers and man-made/cotton blends, it is doubtful that more wool or more wool noils will be used. More wool/man-made fiber combinations are being used so the usefulness of secondary fibers will probably decrease, even if a way were found for them to be practically used in the U.S. industry. Therefore, the proposed target is 13 percent of the total wool fiber used by the textile mill products industry to be satisfied by recovered materials (wool noils).

\subsubsection{Felt Goods, Except Woven Felts and Hats} (SIC 2291)

The production of felt goods involves the use of heat, moisture, and pressure to create a matted product. 'l'he felt is used in utility-oriented applications such as the following:

- Automobile padding and insulation

- Carpet cushions

- Mats

- Pipe and boiler coverings.

Product strength, density, and thickness are more important than color, feel, and fashion, so recovered materials can be used. Some specifications for pressed wool felts require virgin materials, but such requirements are uncommon. 
Currently, about 35 million pounds of recovered materials are used in felts; this is about 59 percent of the total material processed. Members of the industry indicate that this amount will probably increase to 80 percent by 1987 . As manufacturers attempt to cut product costs, more recovered materials will be used. At the same time, there will still be some uses for higher quality felts (where the material is more visible), and these will require a high percentage of virgin fibers. Current information indicates that a growth rate of about 3 percent per year can be anticipated, so the quantity of recovered materials used in felts will grow to 61 million pounds by 1987,80 percent of the 76.3 million pounds to be processed in that year. Therefore, the target for use of recovered materials in this subsector is 80 percent.

\subsubsection{Padding and Upholstery Filling (SIC 2293)}

Padding and wadding are produced as filling for such items as apparel, upholstery, pillows, quilts, and pads. The padding and wadding are composed primarily of recovered materials, generally primary waste. Bulk and fluffiness are required regardless of color or fiber; therefore, this is an ideal application for opened, chopped, or garnetted fibers. The limitations imposed on the use of reprocessed fibers include requirements for flame retardation. A polyester sheet of fabric is often placed between the outer fabric and the inner padiing to keep the padding from burning.

Of the 330 million pounds of fibers currently processed in the llanufacture of padding and upholstery filling, 307.6 million pounds (93 percent) are recovered material. The target for 1987 is experted to remain at 93 pcrcent, because the flame retardation requirement calls for some use of virgin polyester fabric. About $430 \mathrm{million}$ total pounds of material are expected to be processed in 1.987, assuming a 3 percent per year growth rate. This means that just over 400 million pounds of waste will be processed in that year (93 percent of $430 \mathrm{million}$ pounds).

\subsubsection{Processed Waste and Recovered Fibers and}

$$
\text { Flock (SIC 2294) }
$$

Firms classified in the SIC 2294 subsector have as their primary business the processing of waste by-products. The only material processed by these companies is waste, 
either primary or secondary (post-consumer); the waste is used for padding or felt or it is resold to other subsectors. However, since the SIC 2294 firms deal only in the processing of recovered materials $(350$ million pounds in 1978) and uses no virgin fibers for which recovered materials could be substituted, the concept of a recovered materials target is not applicable to this subsector of the industry. Therefore, there is no target proposed for the SIC 2294 companies.

\subsubsection{Nonwoven Fabrics (SIC 2297)}

Nonwovens are produced using a variety of processes. One of these, the spun bonded process, limits the use of recycled materials in this subsector. (This process involves the extrusion of virgin-synthetic pellets into fibers. A web is formed and is bonded together, using the inherent plasticity of heated resin.) Other limitations include the strict requirement that only labeled fibers be used in medical applications. This limit, imposed through the Medical Devices Act, covers fibers used in surgical gowns, masks, and other related products. This requirement for labeled material is often carried over to diapers, food filters, wet wipes, and sanitary products as well, and they are accompanied by high standards for cleanliness, purity, and color. These requirements cannot often be met using recycled fibers, at least not without a severe economic penalty.

The remaining uses for nonwovens are utility-oriented with few, if any requirements for color or consistency. These uses include automobile headliners, sound insulation, luggage fillers, low-end sleeping bags, and padding. In these uses, if the spun bonded process is not used, recycled fibers are appropriate and are extensively used. The use of recycled fibers occurs, however, in less than 25 percent of the nonwoven market.

Interviews with industry executives and association officials indicate that recovered materials are currently used in the nonwoven segment of the industry at a 17 percent rate (110 million pounds of the 641 million pounds processed in 1978). This percentage is likely to decrease slightly in the period up to 1987. The reason for this is the anticipated increase in popularity of the spun 
bonded process, with its requirement for virgin-synthetic pellets. (An increase in the use of this process was predicted in a recent study prepared by Arthur D. Little.) Because of this change in the use of the spun bonded process, a preliminary target of 15 percent was set for 1987. The overall growth rate for nonwovens has been 6.2 percent per year, so nonwovens should consume 1.1 billion pounds of material in 1987, of which 165 million pounds will be recovered materials.

\subsubsection{Cordage and Twine (SIC 2298)}

The cordage and twine industry produces cables, cords, ropes, nets, and twine for a variety of uses. The products used in high strength applications require virgin fiber for consistency, tensile strength, and durability. This limits the use of recycled fibers to the other sectors of this group. Off-quality tire yarn is frequently purchased for use in cordage and twine. This yarn has a few minor flaws and does not meet the very strict standards of the tire cord industry. In addition, recycled fibers, both natural and synthetic, are used in varying percentages for lower strength products. Some clothes lines and most mop yarns are made from 100 percent recycled products, but these are sold at the lower end of the market. Including the off-quality tire yarn used in this segment, recovered materials currently used in this sector total roughly 21 million pounds of the 95 million pounds used. This means that recovered materials account for 22 percent of the total raw fiber input. These figures are not expected to change by 1987. Assuming a 3 percent growth rate for the industry, the recovered materials used in 1987 will be about 27 million pounds of the 124 million pounds processed.

8.2 .8

Summary of Materials Recovery Targets for the Text.i. le Mill. Products Industry

In addition to the facts giveli ill lle plecediny paragraphs, several general industry conditions affect the proposed materials recovery targets:

Most of the primary waste generated within the textile mill products industry is used by the second tier of the industry. 
Intermediate and final customers have extremely high requirements regarding the style, fashion, and characteristics of products manufactured in the first tier of the industry.

- Waste dealers, textile manufacturers, and academic researchers all agreed that technology does not exist to manufacture acceptable first tier textile mill products from primary or secondary textile wastes. These individuals also agreed that such technology is not likely to exist by 1987 .

- The textile mill products industry generates low levels of capital because of its low profitability ( 2 to 3 percent of revenues) and because of increasing competition from lower priced imports.

- Existing government regulations regarding environmental control and employee safety will impose tremendous demands on available capital between now and 1987 .

In Table 8-3, all but two of the 4-digit codes in the first tier of the textile mill products industry have a proposed target of zero percent. The only exceptions are wool processing, $\overline{\text { SICS }} 2231$ and 2283. The following subsectors then, all have targets of zero percent:

- SICs 2211 through 2284, except for SICs 2231 and 2283 (broad woven fabric and yarn mills, wool)

- SIC 2292 (lace goods)

- SIC 2295 (coated fabrics, not rubberized).

These sectors do not. currently use recovered primary or secondary waste and are not likely to begin doing so by 1987. The technology will not be available for using recovered materials to make products that will be acceptable to the customers of these subsectors. 
TADLE $8-.3$

Proposed Recovered Materials Targets for the Textile IAill proaucts Industry

\begin{tabular}{|c|c|c|c|c|c|}
\hline \multirow{2}{*}{ SIC } & \multirow{2}{*}{ INOUSTRY SUELIVISION } & \multicolumn{2}{|c|}{ PROCESSEO MATERIAL, } & \multirow{2}{*}{$\begin{array}{l}\text { 1978 LEVEL OF RECOVEREO MATEHIALS USE } \\
\text { PERLENT OF TOTAL FIBER \& YARN PROCESSEO }\end{array}$} & \multirow{2}{*}{$\begin{array}{l}1987 \text { PROPOSED RECOVERE MATERIALS IARGET } \\
\text { PERCENT OF VOTAL FIBER \& VAHN PROCESSEO }\end{array}$} \\
\hline & & $\begin{array}{l}\text { MILLION } \\
\text { POUNDS }\end{array}$ & $\begin{array}{l}\text { PERCENT } \\
\text { OF TOTAL }\end{array}$ & & \\
\hline 2211 & GROAD WOVEN FABRIC MILLS. COTTON & 2.587 .8 & 16.6 & 0 & $\mathbf{0}$ \\
\hline 2221 & $\begin{array}{l}\text { BRUAJ WOVEN FABRIC MILL.S. } \\
\text { MAN.GADE FIBEA \& SJLK }\end{array}$ & $2,717.5$ & 17.5 & a & $\mathbf{0}$ \\
\hline 2231 & BROAJWOVEN FABRIC MILLS, WOOLL & 173.9 & 1.1 & 13 & 13 \\
\hline 2241 & 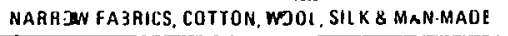 & 194.3 & 1.2 & a & $\mathbf{0}$ \\
\hline 2231 & WOMEN'S FULL LENGTH \& KNEE LENGTH HOSYFAY & 89.8 & 0.6 & 0 & $\mathbf{0}$ \\
\hline 2252 & OTHEQ HOSI :RY & 120.4 & 0.8 & 0 & 0 \\
\hline 2253 & KNIT STER NEAR MILLS & 315.7 & 2.0 & 0 & 0 \\
\hline 2254 & KNIT U.NOERINEAR MILLS & 147.5 & 0.9 & 0 & $\mathbf{0}$ \\
\hline 2257 & CIACULAR KUIT FABRIC MILLS & 1.094 .5 & 7.0 & 0 & 0 \\
\hline 2258 & WARP KNIT FABRIC MILLS & 496.9 & 3.2 & 0 & 0 \\
\hline 2259 & KNITTIUG MaLS, N.E.C. &. .7 & 0.0 & 0 & $\mathbf{0}$ \\
\hline 2261 & BROAO WOVIN FABRIC FINISHERS. COTTON & N/A & N/A & 0 & 0 \\
\hline 2262 & BROAG WOVIN FABRIC FINISH ERS, SILK \& MAN MAUE. & N/4 & N/A & 0 & 0 \\
\hline 2269 & TEXTL. $\equiv$ FIN SHERS, N.E.C. & N/A & N/A & 0 & 0 \\
\hline 2271 & WOVERCARFETS \& RUGS & 83.1 & 0.5 & 0 & 0 \\
\hline 2272 & TUFIET. CAR 'EIS \& RUGS & 1.306 .7 & 8.4 & 0 & 0 \\
\hline 2274 & CARPETS \& RUVIS. N.E.C. & 41.6 & 0.3 & 0 & 0 \\
\hline 2281 & $\begin{array}{l}\text { YARN J'JNNING MILLS, } \\
\text { COTION. SILLC MAN MAGE FIEERS }\end{array}$ & 2.7061 & 17.3 & 0 & 0 \\
\hline 2282 & YAAN FEXTURIZING. COTTON, IILK, MAN-MACE FIBER & 3916 & 5.7 & 0 & 0 \\
\hline 2283 & YAAN AILLS, WOOL & 1239 & 0.8 & 13 & 13 \\
\hline 2284 & THHEAP: MILLS & 139.2 & 0.9 & $\mathbf{0}$ & 0 \\
\hline 2291 & $\begin{array}{l}\text { FELI EOOOS, } \\
\text { EXCEPT WOVEN FELTS \& HATS }\end{array}$ & 58.5 & 0.4 & 59 & 80 \\
\hline 2292 & LACE CDOUS & 5.0 & 0.0 & 0 & 0 \\
\hline 2293 & PALEIEJ \& UPHOLSTERY FILLIVG & 330.0 & 2.1. & 93 & 93 \\
\hline 2295 & COATE I FAUELCS. NOT REUBBEFIZEU & i 36.2 & 0.9 & $\mathbf{0}$ & 0 \\
\hline 2290 & TIAE CORD \& FABAIC & 841.4 & 4.8 & $\mathbf{0}$ & $\mathbf{0}$ \\
\hline 2297 & NON.W.JVEN I ABRICS & 641.0 & 4.1 & 17 & 15 \\
\hline 2298 & CORDACE \& TWINE & 95.2 & 0.6 & 22 & 22 \\
\hline 2299 & TEXTILE GOODS. N.E.C. & & & & \\
\hline
\end{tabular}


In the second tier of the industry, SIC 2296 is also proposed for a zero target. This subsector includes the tire cord and fabric industry, whose products are directly related to auto safety, making strength a primary characteristic. The requirements for production of tire cord and fabric are very strict and rigidly controlled by the Department of Transportation.

Several subsectors of the industry currently use primary waste and small amounts of secondary waste for their final products. Except for wool yarn spinning and weaving, these subsectors are in the second tier of the industry. The following materials recovery targets are proposed for them:

- SIC 2231 Broad Woven Fabric Mills, Wool:

13 percent

- SIC 2283 Yarn Milis, Wool:

13 percent

- SIC 2291 Felt Goods, Except Woven Felt and Hats:

80 percent

- SIC 2293 Padding and Upholstery Filling:

93 percent

- SIC 2297 Nonwoven Fabrics:

15 percent

SIC 2298 Cordage and Twine:

22 percent

It should be noted that most of the companies involved in these subsectors are relatively small firms, consuming much less than 1 trillion Btu's per year. Therefore, they will not be required to report their recovered materials and energy use to DOE.

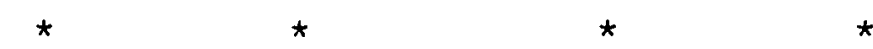

This chapter has discussed the proposed materials recovery targets for the various segments of the textile mill products industry. The following section discusses the effects various government and industry actions could have on the targets. 


\section{GOVERNMENT AND INDUSTRY ACTIONS THAT COULD INCREASE THE USE OF RECOVERED MATERIALS IN THE TEXTILE MILL PRODUCTS INDUSTRY}

Few options for increasing the use of recovered materials in the textile mill products industry are available to the industry, the federal government, or state and local governments. This is true for two reasons:

- It is not technically feasible to use primary or secondary waste to produce first tier, high quality, consumer-oriented textile products acceptable on the U.S. (or European or Japanese) market. This situation is not expected to change between the present and 1987.

- Currently the textile mill products industry uses over 99 percent of its primary waste in producing items common to the second tier sector of the industry. Waste from the apparel industry (SIC 23) is used when excessive transportation costs are not involved.

The primary types of waste that are currently not being fully used are waste generated in the cutting and sewing operations of the apparel industry and secondary (post-consumer) waste. These types of waste should be used and should be the focus of incentive programs to increase the use of recovered materials. However, the technical limitations on first tier product quality must be overcome if effective use is to be made of the 5 to 10 billion pounds of textile waste material in these categories that are currently discarded each year. It was not considered feasible to require the use of recovercd primary or secondary waste in first tier textile products. Such a requirement would essentially destroy the U.S. textile industry because consumers would turn increasingly to foreign imports for high quality goods.

Several actions can be taken to increase the reuse of available apparel incustry waste. Most such steps woulc have to be taken by the government; little additional effort can be expected from the textile mill products industry. 
As previously stated, the textile mill products industry currently consumes from 550 to $750 \mathrm{million}$ pounds of the waste it generates (reworkable and primary). Only 0.7 percent of the waste generated in SIC 22 is discarded in landfills. Most of the waste plus waste generated in the apparel industry is used by second tier textile mills. These mills use essentially all waste that is economically available to them. From an economic viewpoint, then, there is little the industry can do to increase the use of recovered materials. It has no control over the economics of collecting and transporting secondary waste and primary apparel industry waste, and costs in these areas are. currently the factors limiting the use of secondary waste.

The industry could try to change basic textile processes to allow the use of recovered fibers, but certain conditions preclude changes being made in this area. These conditions include the following:

Lack of discretionary funds for research and development into basic textile manufacturing processes for using shorter, recycled fibers. This lack of funds is created by several factors:

- The mature textile industry has low profit margins (about 2 percent of revenues).

- The industry has little access to capital through the debt and equity markets.

- Most generated capital is being absorbed in meeting government $=$ mandated requirements (EPA, OSHA). This leaves little capital available even for asset replacement.

- lhere is no capital for purchasing new high risk equipmint for waste proccosing (if the equipuenl were available). Reasons for this are identical to those cited above. The industry currently does not even generate ennugh discretionary capital to replace obsolete equipment.

The industry currently uses available waste materials for newly developed products in the second tier of the industry, and it will continuc to use waste in this way. However, any products so developed usually compete against existing and imported products, so that economics play a key role in 
product development decisions. For example, it is not economically practical to transport apparel waste great distances, and competition offered by other products limits the amount that can reasonably be devoted to collecting, grading, and reprocessing secondary waste. Nor does the textile mill products industry control the cost of transporting these materials.

As stated, the textile mill products industry competes in a market that imposes very strict quality and characteristic specifications on its products. Additionally, the industry is under increasingly heavy pressure from cheaper imports that are essentially equal in quality and that exhibit the same characteristics as American made textile goods. The industry cannot lower the quality standards of its first tier products and market inferior goods (goods made from recovered materials). Doing so would, in all likelihood, force its customers further into foreign markets, and this would undermine the industry, possibly causing many of the marginal firms to simply cease operating.

In summary, given current and projected market and economic conditions, there is very little the textile mill products industry can practically do to increase the use of apparel waste (primary) and secondary (post-consumer) waste. Its actions in these areas must be limited to new product development in the second tier of the industry; new products could make possible the increased use of primary and secondary waste but within existing economic conditions.

9.2

SEVERAL POSSIBLE GOVERNMENT ACTIONS COULD STIMULATE THE USE OF RECOVERED MATERIALS IN THE TEXTILE MILL PRODUCTS INDUSTRY

No government agency can do much to affect the buying preferences of the customers of the textile mill products industry. However, several actions could be taken that would influence the use of recovered materials in the industry. Many of these actions have been previously considered during legislative debates, but they have subsequently been defeated. Given this background, then, it seems necessary to add that, between now and 1987, these actions are not likely to become effective incentives for using recovered materials. 
9.2.1 Government-Supported Research and Development in Basic Textile Processes

The government could use tax credits, tax holidays, direct subsidies, or research grants to encourage the first tier of the textile mill products industry to use recovered primary and secondary materials in its products. New textile processes making use of the recovered materials wo'lld be developed. Processes should be found for using recovered materials to make first tier quality products. Researchers at leading university textile departments indicate that no appreciable research is being done in this area and none is anticipated.

\subsubsection{Government-Supported Research and Development in Waste Reprocessing and Handling Equipment}

Through tax credits and research grants, the government could encourage the development of methods for reprocessing some primary and secondary waste into forms acceptable to the first tier of the textile mill products industry. No equipment is currently available or anticipated for such work and no research is being done in this area. Development of technologies to make recovered materials usable in first tier products would greatly increase the use of primary and secondary waste.

9.2.3 Amendments to the Wool Labeling Act and Incentives for the Wool Reprocessing Industry

The Wool Labeling ACL of 1938 was a major cause of the contraction of the wool industry in the United States, because it made reused and reprocessed U.S. woolen goods unmarketable. Foreign woolen goods are not so restricted; therefore, most woolen goods sold in the United States are imported and many are fabricated from used wool. The government should analyze the possibility of using tax credits, tax holidays, and direct subsidies to reestablish the woll reprocessing industry, but first the wool Labeling Act should be amended. As stated above, an attempt to amend this art. was recently made, but to no avail. The current wool industry is so small ( 1 to 2 percent of the total material used) that its influence is limited, and projections indicate that the use of wool is not likely to grow appreciably between now and 1987 because of the price of wool compared with those of other fibers. 
9.2.4 Mandatory Environmental and Regulatory Standards (EPA and OSHA)

As previously discussed, the current environmental and personnel safety standards imposed on the textile mill products industry will consume essentially all of the capital generated by the industry between now and 1987 . These standards will create a large continuing demand on generated capital both because of initial installation expenses and because of operating costs. Obviously, capital for additional research and development and for installation of waste reprocessing equipment will have a much lower priority than these mandated expenditures. If these environmental and regulatory standards were relaxed, the program for use of recovered materials could benefit, since capital would be made available for development of new materials recovery equipment.

9.2 .5

Transportation Subsidies for Moving Primary and Secondary waste

The use of secondary waste and of apparel industry (primary) waste is limited by transportation economics. For that reason, a subsidy for hauling such material from areas like the garment districts of New York and New Jersey to the reprocessors and mills in the southeast could make the use of such waste economically attractive. Reprocessors and second tier textile companies have indicated a need for good quality textile waste but only up to a given price; the extra cost of transportation cannot be too great. A subsidy here could have an immediate and direct effect on the use of recovered materials in the second tier of the textile mill products industry.

9.2.6 Modification of Government Purchasing Policies

Several government policies for purchasing products from the first and second tiers of the textile mill products industry currently require the use of virgin materials. If these requirements were changed, recovered materials could be used in items such as uniforms, blankets, mattresses, and other textile products.

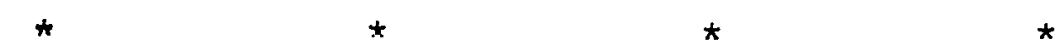

This chapter has aiscussed several ways in which government, prinarily the federal government, could encourage the use of recovered materials in the textile mill products industry. None of these options is expected to have an appreciable effect in the industry before 1987 . 
Public Law 95-619

95th Congress

\begin{tabular}{l} 
Nov. 9, 1978 \\
\hline [H.R. 5037] \\
National Energy \\
Conservation \\
Policy Act.
\end{tabular}

\author{
An Act
}

For the relief of Jack $\mathbf{R}$ Misner.

Be it enacted by the Senate and Honse of Representatives of the Cinited States of America in Congress assembled,

\title{
TITLE I-GENERAL PROVISIONS
}

SEC. 101. SHORT TITLE AND TABLE OF CONTENTS.

(a) Sinor TituE. - This Act may be cited as the "Sational Energy ('onservation Policy Act".

(b) TABite UF CuNTENTS.-

\section{TITLE IV-ENERGY EFFICIENCY OF CERTAIX PRODCCTS AND PROCESSES}

Pabt I-Esergi Efficiency Staxdards fob Attomobieg

Sec. 401. Fuel economs information.

Sec. t02. Ciril penalties relating to automobile fuel efficiencs.

Sec. 403. Disclosure in labeling.

Sec. 404. Study.

Part 2-Exerg Efficiexct Staydards for Cossumer Prodoctg Otaeb Thas AUTOMOBாES

Sec. 421. Test procedures.

Sec. 422. Energy efficiency standards.

Sec. 423. Assessment of ciril penalties.

Sec. 424 . Effect of standards on other laws.

Ser. 125. Technical and conforming amendments.

Sec. 426. Appropriations a utborization.

Sec. 427. Effects of other lar's on procedures.

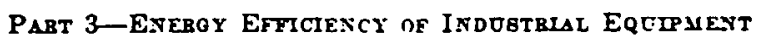

Sec. 441. Energy efficiency of industrial equipment.

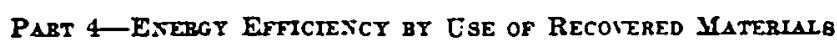

Sec. 461 . Use of recorered materials. 


\section{PART 1-ENERGY EFFICIENCY BY USE OF RECOVERED MATERIALS}

SEC. 461. LISE OF RECOVERED MATERIALS.

(a) Fixdivgs.-The Congress finds that-

(1) significant amounts of industrial energy and other scarce natural resources are conserved in certain major energy-consuming industries where recovered materials are utilized in their manufacturing operations;

(2) substantial additional volumes of industrial energy and other scarce natural resources will be conserved in future years if such major energy-consuming industries increase to the maxinum feusible extent utilization of recovered materials in their manufacturing operations;

(3) millions of tons of recoverable materials which could he used by such industries are needlessly wasted and buried each year at great cost to State and local governments, while technology and methods exist whereby those materials could readily he made arailable for utilization; and

(4) the recovery and utilization of such recovered materials can substantialls reduce the dependence of the United States on foreign natural resources and reduce the growing deficit, in its balance of payments.

(b) PrRposes. - The purposes of this subtitle are to conserve valuable energy and scarce natural resources, promote the national security, and protect the environment by-

(1) directing that targets for increased industrial utilization of recovered materials be established for certain major energy-consuming industries;

(2) creating procedures whereby such indust ries may cooperate with the Federal Government in the establishment and achieve. ment of such targets; and

(3) providing incentives for increased industrial utilization of encrgy-saving recovered materials in such majnr energy-consum ing indust ries.

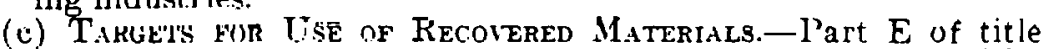
III of the Encrgy Policy aind Cunservarion Act, as redesignated by section 441 (b) (2) of this Act, is amended by inserting the following new sertinn aftor seotion 371 :

\footnotetext{
"TARGETS FOR TSF, NF REGQYERED M.ATERIALS
}

"SEc. 374A. (a) For purnnces of this seotion, the terni 'ollesy" saving recovered materials' means aluminum, copper. lead, zinc. iron.

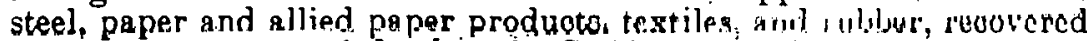
from solid waste, as defined in the Solid Waste Disposal Act.

"(b) Within one year after the date of the enactment of this section. the Secretary shall set targets for increased utilization of energy- 
saving recovered materials for each of the following industries: the metals and metal products industries, the paper and allied products industries, the textile mill products industry, and the rubber industry. Such targets-

"(1) shall be based on the best a vailable in formation,

"(2) shall be established at levels which represent the maximum feasible increase in utilization of energy-saving recorered materials each such industry can achieve progressively by January $1,198 \pi$, and

"(3) shall be published in the Federal Register, togrther with a statement of the basis and justification for such taryets.

"(c) In establishing targets under subsection (b), the Secretary shall consult with the Administ rator of the Environmental Protcction Agency and with each of the major industries subject to this section, and shall consider-

"(1) the technological and economic ability of each such industry progressively to increase its utilization of energy-saving recovered materials by January $1.198 \mathrm{i}$, and

"(2) all actions taken or which before such date could be taken by each such industry, or by Federal, State, or local governments to increase that industry's utilization of energy-saving recovered materials.

"(d) Any target established under subsection (b) may be modified if the Secretary-

"(1) determines that such target cannot reasonably be attained, or that it should require greater use of energy-saring recovered materials, and

"(2) publishes such determination in the Federal Register, together with a basis and justification for such modification.

"(e) Within each of the industries subject to this section. the Sec. retary shall notify each corporation which is a major energy consumer (within the meaning of section 373 ) of the requirements of this section. Not later than January 1. 1979. the chicf exerutive ofticer of anch such corporation (or individual designated by such officer) shall include in his report to the Secretary under section $37 . \overline{\text { or }}$ or section $376(\mathrm{~g})$ applies, prepare and transmit a report which includes, a statement of the volume of energy-saving recovered materials that such corporation is using in each of its manufacturing operations located in the United States and what plans, if any, the corporation has io increase the utilization of such materials in those operations in each of the nest ten years. Not luter thaii January 1. 1080. and annually thoreafter, each such corporation shall include in such report a statement of the progress it has made to increase its utilization of energy-saving recovered materials to reach targets established under this section by the Secretary for its industry. Such reports shall contain such information as the Secretary determines is necessary to measure progress toward meeting the industry targets established under this section.

"(f) The Secretary shall include in his annual report under section $375(e)$ a report on the industrial energy and natural resource conservation and recovery program established under this section. Each such report shal] include-

"(1) a summary of the progress made toward the achiprement of turgets set by the Secretary under this section: and

"(2) a summary of the progress made toward meeting such targets since the date of publication of the previous report, if ans.". 
(d) Technical Amendmexts.-(1) Section 376 of such Act is amended by-

(A) inserting "or $374 A$ " after "section 372 " in subsection (b), and

(B) inserting "or any target under section $374 A$ " ufter " 374 " in subsections (c) and (f).

(2) The cable of contents of such Act is amended by inserting after the item relating to section 354 the following new item:

.3itA. Targets for use of recorered materials.". 
Airplane cloth, cotton

Alpacas, cotton

Automotive fabrics, cotton

Awning stripes, cotton: mitso

Bags and bagging, cotton: made in weaving mills

Balloon cloth, cotton

Bandage cloths, cotton

Bark cloth, cotton

Basket weave fabrics, cotton

Bathmats, cotton: made in weaving mills

Batiste, cotton

Bedspreads, cotton: made in weaving mills

Bird's-eye diaper cloth, cotton

Blankets and blanketings, cotton: mitse

Bombazinu, cotton

Book cloth, mitse

Broadcloth, cotton

Brocade, cotton

Brocatelle, cotton

Buckram

Bunting cloths, mitse

Butter cloths

Cambric, cotton

Camouflage nets, mitse

Canton flannels, cotton

Canvas, mitso

Card roll fabrics, cotton

Casement cloth, cotton

Chafer fabrics, cotton

Chambrays

Cheese bandages, mitse

Cheesecloth

Chenilles, tufted textile: mitse

Cheviots, cotton

Chintz, cotton

Corduroys, cotton

Corset fabrics, cotton

Cotton broad woven goods

Cottonades

Coutil, cotton

Coverts, cotton

Crash toweling, cotton

Crepes, cotton

Cretonne, cotton

Crinoline

Damasks, cotton

Denims

Diaper fabrics

Dimities

Dishcloths, made in weaving mills

Draperies and drapery fabrics, cotton: mitse

Dress fabrics, cotton

Drilis, cotton

Duck, cotton

Duvetyn, cotton
Elastic fabrics, cotton: over 12 inches in width

Express stripes, cotton

Fabries, broad woven: cotton

Filter cloth, cotton

Flannelette

Flannels, cotton

Frieze, cotton

Friezette, cotton

Furniture denim

Gabardine, cotton

Galatea, cotton

Gauze, mitse

Ginghams

Glass toweling, cotton

Glove fabrics, cotton: mitse

Grosgrain, cotton

Handkerchief fabrics, cotton

Hickory stripes, cotton.

Huck toweling

Interlining material, cotton

Jacquard woven fabrics, cotton

Jean fabrics

Lau ndry fabrics, sotton

Laundry nets, mitse

Lawns, cotton

Leno fabrics, cotton

Long cloth, cotton

Luggage fabrics, cotton

Madras, cotton

Marquisettes, cotton

Matelasse, cotton

Messaline, cotton

Mitten flannel, cotton

Moleskins, mitse

Momie crepe, cotton

Mosquito netting mitse

Muslin, cotton

Nainsook, cotton

Nets and nettings, mitse

Opaline, cotton

Organdy, cotton

Osnaburge

Outing flannel, cotton

Oxfords (cotton fabrics)

Pajama checks, textile

Percale

Percaline, cotton

Pile fabrics, cotton

Pillow tubing, mitse

Pillnumasas, mitca

Pin checks, cotton

Pin stripes, cotton,

P:iques, cotton

Plaids, cotton

Plisse crepe, cotton

Plushes, cotton

Pocketing twill, cotton

Pongee, cotton
Poplin, cotton

Press cloth

Print cloths, cotton

Ratine, cotton

Rep. cotton

Romaines

Säil cloth, mitse

Sateens, cotton

Scrim, cotton

Scrub cloths mitse

Seat cover cloth, automobile: cotton

Seersuckers, cotton

Sheets and sheetings, cotton: mitse

Shirting fabrics, cotton

Shoo fabrics, mitse

Silesia, cotton

Slip cover fabrics, cotton

Stretch fabrics, cotton

Suiting fabrics, cotton

Surgical fabrics, cotton

Table cover fabrics, cotton

Table damask, cotton

Tapestry fabrics, cotton

Tarlatan, cotton

Tenuge, mitse

Terry woven fabrics, cotton

Tickings, mitse

Tobacco cloths, mitse

Towels and toweling, cotton: made in weaving mills

Tracing cloth, cotton

Trouserings, cotton

Tubing, seamless: cotton

Twills, cotton

Typewriter ribbon cloth

Umbreila cloth, cotton

Underwear fabrics, except knit: cotton Upholstery fabrics, cotton

Velours

Velveteens

Velvets, cotton

Voiles, cotton

WJafflu cloth, cotton

Washcloths, except knit: made in weaving mills

Weaving mills, cotton broad woven fabrics

Nignan, cotton

Window shade cloth, cotton

Yarn-dyed fabrics, cotton 
Industry

No.

Acetate broad woven fabrics

Acrylic broad woven fabrics

Automotive fabrics, man-made fiber

Bedspreads, silk and man-made fiber: mitse

Blanketings, man-made fiber

Broad woven fabrics, silk and man-made fiber

Canton crepes

Crepe satins

Draperies and drapery fabrics, man-made fiber and silk : mitse

Dress fabrics, man-made fiber and silk

Duvetyn, man-made fiber and silk

Elastıc fäbrıcs, man-made tıber and sılk: over 12 inches in width

Fabrics, broad wovon: man-made fibor and silk

Failles

Fiberglass fabrics

Flat crepes

French crepes

Fur-type fabrics, man-made fiber

Georgettes

Glass broad woven fabrics

Jacquard woven fabrics, man-made

fiber and silk

Leno fabrics, man-made fiber and silk.

Lining fabrics, man-made fiber and silk

Linings, rayon or silk: mitse

Marquisettes, man-made fiber

Modacrylic broad woven fabrics

Neck tie fabrics, man-made fiber and silk: braad woven

Nylon broad woven fabrics

Nyrril broad woven tabrics

Haper broad woven tabrics

Parachute fabrics

Pile fabrics. man-made fiber and silk

Fluslies, man-made fiber aisu silk

Polyester broad woven fabrics

Polyothylono broad woven fabrics

Polypropylene broad woven tabries

Hongoo; mon mado tibor and silk

Poplin, man-made fiber

Uuilts, man-made tiber and silk: mitse

Rayon broad woven fabrics

Saran broad woven fabrics

Satins

Serges, man made tibor

Shantungs, man-made fiber and silk

Shirting fabrics, man-made flber and silk

Silk broad woven fabrics

Slip cover fabrics, man-made fiber and silk

Spandex broad woven fabrics

Suiting fabrics, man-made fiber and silk
Taffetas

Tapestry fabrics, man-made fiber and silk

Textile milis, broad woven: silk and man-made fiber including glass

Textile warping, on a contract basis

Twills, man-made fiber

Underwear fabrics, except knit: man-made fiber and silk

Upholstery fabrics, man-made fiber and silk

Velvets, man-made fiber and silk

Vinal broad woven fabrics

Vinyon broad woven fabrics

Voiles, man-made fiber and silk 
Alpacas, mohair: woven

Bale dyeing of yarn and fabrics, of wool and similar fibers: except knit

Billiard cloths, mitse

Blankets and blanketings, of wool and similar fibers: mitse

Bleaching yarn and fabrics, of wool and similar fibers: except knit fabric

Broad woven fabrics, of wool, mohair. and similar fibers

Burling and mending cloth for the trade

Calendering of wool, mohair, and similar fiber fabrics: except knit

Cloth, wool: mending-for the trade

Dyeing and finishing of wool and similar flbers: except knit

Fábric, animal fiber: broad woven

Fabric finishing of wool, mohair, and similar fibers: except knit

Fabrics, broad woven: of wool, mohair. and similar fibers

Felts, of wool, mohair, and similar fibers: woven

Finishing of wool, mohair, and similar fiber fabrics: except knit

Flannels of wool, mohair, and similar fibers

Haircloth of wool, mohair, and similar fibers

Mill menders, contract: wool, mohair. and similar fibers

Napping of wool, mohair, and similar fiber fabrics

Narrow fabrics: dyeing and finishing of wool, mohair, and similar fibers

Overcoatings, of wool, mohair, and similar fibers

Pantings: of wool, mohair, and similar fibers

Papermakers' felts, woven of wool, mohair, and similar fibers

Raw stock dyoing and finishing of wool. mohair, and similar trbers

Refinishing and sponging cloths of wool, mohair, etc., for the trade

Serges of wool, mohair, and similar fibers

Shrinking cloth of wool, mohair, and similar fibers: for the trade

Skirtings

Sponging and rafinishing elath of wool and similar fibers: for the trade

Suitings of wool, mohair, and similar fibers

Trouserings of wool, mohair, and similar fibers
Upholstery fabrics, wool

Vat dyeing of tops, yarn, and textiles: of animal fibers-except knit

Weaving mills, broad waven fabrics:

of wool, mohair, and similar fibers

Worsted fabrics, broad woven

Yarn bleaching, dyeing, and finishing:

of wool, mohair, and similar fibers 
No. Fiber

Apparel webbing

Auto wind lace

Banding, spindle

Beltings, woven or braided

Bindings, textile: mitse

Braids, textile

Braids, tubular nylon and plastic

Cords, fabric

Corset laces

Cotton narrow fabrics

Elastic narrow fabrics, woven or braided

Elastic webbing

Electric insulatiriy lapus and bralds, except plastic

Fabric, animal fiber: narrow woven

Fringes, weaving

Gimps, mitse

Glass narrow fabrics

Glove lining fabrics

Hat band fabrics

Hose fabric, tubular

Insulating tapes and braids, electric

Labels, woven

Lace, auto wind
Laces, corset and shoe: textile

Lacings, mitse

Narrow woven fabrics: cotton, wool, silk, glass, and man-made fiber

Rayon narrow fabrics

Ribbons, mitse

Rickrack braid

Rubber thread and yarns, fabric covered

Shoelaces, except leather

Slide fastener tapes

Spindle banding

Strapping webs

Tapes, fabric

Textile mills, narrow woven: fibers including glass

Tie tapes, woven or braided

Trimmings, textile: mitse

Venetian blind tapes

Weaving mills: cotton, wool, silk, and man-made fiber narrow fabrits

Webbing, woven; except jute

Wisking

Zipper tape
Dyeing and finishing women's full and kilue length hosiery

Hosiery, women's and misses' full length and knee length

Panty hoso
Stockings, women's and misses' ful! length and knee length

Stretch tights, seamless and full. fashioned
Anklets (hosieryl, seamless or fullfashionod

Dyeing and finishing hosiery, except women's full and knee length

Horiery, omoopt women's and misjes' full length and knee length hosiery Infants' and children's hosiery

\author{
Men's, boys', and girls' hosiery \\ Slipper socks, mitse \\ Socks, seamless and full-fashioned \\ Socks, slipper, mitse \\ Srockings, excép̄t women's and misses' \\ full length and knee length stocking
}


No.

Apparel, except gloves, hosiery, and underwear-mitse

Basque shirts, mitse

Bathing suits, mitso

Bathrobes, mitse

Beachwear, mitse

Bedjackets, mitse

Blouses, mitse

Body stockings, mitse

Caps, mitse

Collar and cuff sets, mitse

Dresses, hand knit: for the tradc

Dresses, mitse

Dyeing and finishing knit outerwear. except hosiery and gloves

Hand knitting of outerwear, for the trade

Hats, mitse
Knit Underwear Mills

Drawers, apparel: mitse

Dyoing and finishing knit underwear

Nightwear, mitse

Panties, mitse

Shirts (underwear), mitse

Circular knit fabrics of all materials

Cloth, circular knit: mitse

Dyeing and finishing circular knit fabrics

\section{Warp Knit Fabric Mills}

Cloth, warp knit: mitse

Uyérrig and Ilnishing warp knit fabrics Finishing of warp or flat knit fabrics Lace, knit

Mosquito netting, warp knit: mitse
Headwear, mitse

Housecoats, mitse

Jerseys and sweaters, mitse

Leotards, mitse

Lounging robes, mitse

Mufflers, mitse

Neckties, mitse

Outerwear, except hosiery and gloves:

mitse

Scarfs, mitse

Shawls, mitse

Shirts (outerwear), mitse

Shoulderettes, mitse

Ski suits, mitse

Slacks or pants, mitse

Suits, mitse

Sweaters and sweater coats, mitse

Wristlets, mitse
Slips, mitse

Step-ins, mitse

Underwear, mitse

Union suits, mitse
Fabric, circular knit

Jersey cloth, mitse

Pile fabric, circular knit
Bags and bagging, made in knitting mills

Bedspreads, made in knitting mills Curtains, made in knitting mills

Dishcloths, made in knitting mills

Dyeing and finishing $k n i t$ gloves and mittens

Elastic girdle blanks, made in knitting mills
Netting, knit

Pile labiic, warp or flat lenit

Tricot fabrics

Warp or flat knit fabrics of all materials
Girdles (elastic) and other foundation garments, mitse

Gloves, made in knitting mills

Linings, shoe: made in knitting mills

Meat bagging: made in knitting mills

Mittens, made in knitting mills

Stockinette, made in knitting mills

Towels, made in knitting mills

Washcloths, made in knitting milis 
Bleaching cotton broad woven fabrics Bleaching, kier: continuous machine

Calendering of cotton fabrics

Dyeing cotton broad woven fabrics

Embossing cotton broad woven fabrics

Finishing of cotton broad woven fabrics

Fire-resistance finishing of cotton broad woven fabrics

Mercerizing cotton broad woven fabrics

Mildew proofing cotton broad woven

fabrics

Napping of cotton broad woven fabrics
Preshrinking cotton fabrics, for the trade

Printing and finishing of cotton broad woven fabrics

Refinishing and sponging cotton broad woven fabrics, for the trade

Shrinking cotton cloth, for the trade

Sponging and refinishing cotton cloth, for the trade

Sueding cotton broad woven goods

Teaseling cotton broad woven goods

Water repellency finishing of cotton broad woven fabrics
Bleaching man-made fiber and silk broad wovon fabrics

Calendering of man-made fiber and silk broad woven fabrics

Dyeing man-made fiber and silk broad woven fabrics

Embossing man-made fiber and silk broad woven fabrics

Finishing of man-made fiber and silk broad woven fabrics

Fire resistance finishing of man-made fiber and silk broad woven fabrics

Napping of man-made fiber and silk broad woven fabrics
Preshrinking man-made fiber and silk broad woven tabrics, for the trade

Printing man-made fiber and silk broed woven fabrics

Shrinking man-made fiber and silk cloth, for the trade

Silk broad woven fabric finishing

Sueding man-made fiber and silk broad woven fabrics

Teaseling man-made fiber and silk broad woven fabrics
Bleaching raw stọck, yarn. and narrow fabrics: uxcept knit and wool

Braided goods cxeept wool: bleaching. dyeing, printing and other finishing

rinth monding, oucopt wool: for the liade

Dyeing raw stock, yarn, and narrow fabrics: except knit and wno!

Embossing linen broad woven fabrics

rinislingy raw stock, yarn, and narrow tabrics: except knit and wool

\section{1}

\section{Woven Carpets and Rugs}

Aircraft floor coverings, woven

Art squares, woven textile fiber

Automobile floor coverings, woven

Axminster corpets

Bathmatș, woven textile fiber: not made

in weaving mills

Carpets, woven tcxtile fiber

\section{Gassing yarn}

Labels, cotton: printed

Linen tabrics: dyeing, finishing, and printing

Mercerizing yarn, braided goods, and narrow fabpics: except knit and wool

Mill enders, contract: cotton, silk, and man"uale riber

Printing narrow tabrics, except knit and wool 
Bathmat sets, tufted

Bathmats, tufted

Carpets, tufted

Dyoing and finishing of tufted rugs and carpets
Rugs, tufted

Scatter rugs, tufted
Art squares: twisted paper, grass, reed, coir, sisal, jute, and rag

Carpets: twisted paper, grass, reed, coir, sisal, jute, and rag

Door mats: twisted paper, grass, reed coir, sisal, jute, and rag

Floor coverings: twisted paper, grass. reed, coir, sisal, jute, and rag
Mats and matting: twisted paper, grass, reed, coir, sisal, jute, and rag

Rugs, braided and hooked

Rugs: twisted paper, grass, reed, coir, sisal, jute, and rag
Acetate yarn, made from purctiased staple: spun

Acrylic yarn, made from purchased staple: spun

Carded yarn, cotton

Carpet yarn, cotton

Combed yarn, cotton

Cordage yarn, cotton

Crochet varn: cotton, silk, and man-made staple

Darning yarn: cotton, silk, and man-made staple

Embroidery yarn: cotton, silk, and man-made staple

Knitting yarn: cotton, silk; and man-made staple

Man-made staple fiber yarn, spun

Modacrylic yarn. made from purchased staple: spun

Nylon yarn, spinning of staple
Nytril yarn, made from purchased

staple: spun

Polyester yarn, made from purchased staple: spun

Polypropylene yarn, made from purchased staple: spun

Rayon yarn, made from purchased staple: spun

Saran yarn, made from purchased staple: spun

Spinning yarn: cotton, silk, and man-made staple

Vinal yarn, made from purchased staple: spun

Vinyon yarn, made from purchased staple: spun

Weaving yarn: cotton, silk, and man-made staple

Yarn, cotton, silk, ani-t man-made staple
Acetate filament yarn: throwing, twisting, winding, or spooling

Acrylic and modacrylic filament yarn: throwing, winding, or spooling

Beaming yarns, for the trade

Nylon yarn: throwing, twisting, winding, or spogling of continuous filament

Polyester filament yarn: throwing, twisting, winding, or spooling

Polypropylene filament yarn: throwing, twisting, winding, or spooling

Rayon yarn, made from purchased filament yarn: throwing, twisting, winding
Saran filament yarn: throwing, twisting, winding, or spooling

Spooling yarn: cotton, silk, and man-made fiber continuous filament

Textured yarns

Throwing winding, or spooling of filament yarn: silk and man-made fiber

Twisting yarn: silk and man-made fiber continuous filament

Vinat filament yarn: throwing, twisting, winding, or spooling

Vinyon filament yarn: throwing, twisting, winding, or spooling

Winding yarn: cotton, silk, and man-made fiber cuintiruuus filament 
Animal fiber yarn: spinning twisting, winding, or spooling

Crochet yarn: wool, mohair, or similar animal fiber

Darning yarn: wool, mohair, or similar animal fiber

Embroidery yarn: wool, mohair, or similar animal fiber

Knitting yarn: wool, mohair, or similar animal fiber

Mohair yarn: spinning, twisting, winding, or spooling

Rug yarn: wool, mohair, or similar animal fiber

\section{Thread Mills}

\section{Cotton thread}

Crochet thread: cotton, silk, and manmade fiber

Darning thread: cotton, silk, and marmade fiber

Embroidery thread: cotton, silk, and man-made tiber

Hand knitting thread: cotton, silk, and man-made fiber

Man-made fiber thread

ivylun thread

Polyester thread
Thread: wool, mohair, or similar animal fiber

Twisting yarn: wool, mohair, or similar animal fiber

Weaving yarn: wool, mohair, or similar animal fiber

Wool yarn: spinning, twisting, winding, or spooling

Yarn, carpet and rug: animal fiberspinning, twisting, and spooling

Yarn: weaving machine knitting, and hand knitting animal fiber

\section{Rayon thread}

Sewing thread: cotton, silk, and manmade fiber

Silk thread

Spinning thread: cotton, silk, and man-made fiber

Tatting thread: cotton, silk, and manmade fiber

Thread, except linen or wool: bleaching, dyeing, and finishing

Thread: except linen wool, mohair, or similar animal fibers
Acoustic felts, except wover

Autnmntive felts, except woven

Carpet cushions felt

Felt goods, except woven felts and hats: wool, hair, jute, or other fiber Insulating felts, except woven

Ironing board felts, except woven

Lining felts, except wovan

\section{Lzo0 Goods}

Bèd sèts, lace

renvers, lace: chair, droçepr; piono. and table

Curtains and curt ain fabrics, lace

Dyeing and finishing lace goods

Edgings, lace

Galloons, lace
Lin̈ings, carpet: telt, except woven

Mats, felt: excep l wuven

Pads and padding, felt: except woveir

Pipe and boiler covering, felt

Paliching folts, oxeop: woron

Pressed wool felts

Punched felts

Trimming felts, except woven
Lace goods: curtains, bedspreads,

iable covors, flounoungig, and insertions

Laces: Barmen, uubbinet, levers, and Nottingham

Netting made on a lace or nct machine 
Industry

No.

2293 Paddings and Upholstery Filling

Apparel filling: cotton mill waste, kapok, and related materials

Batts and batting: cotton mill waste, kapok, and related materials

Hair, curled: for upholstery, pillow, and quilt filling

Padding and wadding, except excelsior
Pads, fiber: henequen, sisal, istle

Pillow filling: curled hair, cotton waste, moss, hemp tow, kapok, etc.

Quilt filling: curled hair, cotton waste, moss, hemp tow, kapok, etc.

Upholstery filling, except excelsior Wads and wadding, except excelsior
Carbonized rags

Fibers, textile: recovery from textile mill waste and rags

Flock (recovered textile fibers)

Garnetting of textile waste and rags

Oakum

Packing, twisted jute

$$
2295
$$

\section{Coated Fabrics, Not Rubberized}

Buckram: varnished, waxed, and im pregnated

Cambric: varnished, waxed, and im pregnated

Cloth, varnished glass

$r$. ing and impregnating of fabrics, except rubberizing

Fabrics, coated and impregnated: except rubberized

Laminating of fabrics

Leather, artificial

Mats, varnished glass

Metallizing of fabrics

Oilcloth

2296

Tire Cord and Fabric

Cord for reinforcing rubber tires, industrial belting, and fuel cells

Bonded-fiber textiles, except felt Fabrics, bonded fiber: except felt Nonwoven textiles, except wool
Processing of textile mill waste and recovering fibers

Recovering textile fibers from clippings and rags

Wool shoddy

Wool waste processing

Pyroxylin coated fabrics

Resin (plasticl coated fabrics

Sealing or insulating tape for pipe.

fiberglass coated with tar or asphalt

Sleeving, textile: saturated

Tape, varnished: plastic, and other coated (except magnetic) - mfpm

Tubing, textile: varnished

Waterproofing fabrics, except rubberizing

Waxing of cloth

Yarns, plastic coated: made from purchased yarns

Fabric for reinforcing rubber tires, in dustrial belting, and fuel cells

Ribbon, nonwoven (yarn bonded by plastic)

Spunbonded fabrics 
Binder and baler twine

Blasting mats, rope

Cable, fiber

Camouflage nets, not made in weaving mills

Cargo nets (cordage)

Cord, braided

Cordage: abaca (Manila), sisal, henequen, hemp, jute, and other fibers

Fish nets and seines, made in cordage or twine mills
Fishing lines, nets, seines: made in cordage or twine mills

Hard fiber cordage and twine

Insulator pads, cordage

Nets, rope

Rope, except asbestos and wire

Slings, rope

Soft fiber cordage and twine

Trawl twine

Twine

Wire rope centers
Bagging, jute: made in jute weaving mills

Burlap, jute

Coir yarns and roving

Crash, linen

Fabrics: linen, jute, hemp; ramioexcept felt

Flax yorns and roving

Grease, wool

Hand woven fabrics

Hemp yarn, thread, roving, and textiles

Narrow woven fabrics: linen, jute, hemp, and ramie

Noils, wool and.mohair

Preparing textile fibers for spinning (scouring and combing)

$R$ amie yarn, thread, roving, and textiles

Rayon tops, combing and converting
Roves, flax and jute

Rugbacking, jute or other fiber: except felt

Slubs and nubs (cutting up fibers for use in tweeds)

Texille mills: linen, jute, hemp, and ramie yarn, thread, and fabric

Tops, combing and conver liny

Tops, man-made fiber

Tow to top mills

Towels and towelings, linen and linen-and-cotton mix tures: mitse

Thread: linen, hemp, and ramie

Webbing, jute

Wool scouring and carbonizing

Wool toos. combing and converting

Yarn: flax, jute, hemp, and ramie

Yarn, metallic, ceramic, or paper fibers

Yarns, specialty and novelty
Coats: tailored-men's, youths', and boys

Plrumeris uniforms

Formal jackets, men's and youths'

Military uniforms, men's and youths'

Overcoats: men's, youths', and boys'

Policemon's uniforma

Suits: men's, youths', and boys'
Tailored dress and sport coats: men's and boys'

I'opcoats: men's, youths', and boys'

Tuxedos

Uniforms, men's: suits, coats, and overcoats

Verts: except suede, leatherette, blanket lined-men's and boys 
Blouses, boys' : mfpm

Collars, men's and youths': $m$ fpm

Flannel shirts, except work shirts:

men's, youths', and boys'

Nightshirts: men's, youths', and boys'-mfpm

Nightwear: men's, youths', and boys' (except robes)- mfpm

Pajamas: men's, youths', and boys'mfpm

Polo shirts: men's, youths, and boys'mfipm
Shirts, except work shirts: men's and boys - mfpm

Shirts, flannel: except work shirtsmen's. youths', and boys'

Sports shirts: men's, youths', and boys'-mfpm

T-shirts: men's, youths', and boys'mfpm

Uniform shirts 